Founder: Federal Scientific Center for Medical and Preventive

Health Risk Management

Technologies Federal Service

for Surveillance on Consumer

Rights Protection and

Human Wellbeing

\section{Contact Information:}

82 Monastyrskaya St.,

Perm, 614045, Russia

Tel/Fax: + 7 (342) 237-25-34

E-mail: journal@fcrisk.ru

Site: journal.fcrisk.ru/eng

Editor and corrector-M.N. Afanaseva

Technical Editor - M.M. Tsinker

Translators - N.V. Dubrovskaya,

N.A. Tregubova

All rights reserved. No part of this publication may be stored in the computer's memory or reproduced in any way without the prior written permission of the publisher.

The publication 30.12.2018.

Format $90 \times 60 / 8$.

Order No. $285 / 2018$.

Edition is 500 copies.

The price is free.

The Journal is registered by The Federal Service For Supervision Of Communications, Information Technology, And Mass Media (Roscomnadzor). Register certificate СМИ - ПИ No. ФС 77-52552

issued on January 21, 2013

Address of the publisher and printing house:

29 Komsomolsky ave., Perm, 614990,

Russia, tel.: +7 (342) 219-80-33

Printed by the Publishing House of Perm National Research Polytechnic University (29 Komsomolsky ave., Perm, 614990, Russia, tel.: +7 (342) 219-80-33)

\section{Subscription number: catalog "Russian Post" ("Interregional subscription agency") 04153}

ISSN (Print) 2308-1155

ISSN (Online) 2308-1163

ISSN (Eng-online) 2542-2308

The edition is granted the financial support by the Perm Regional Ministry for

Educational and Science

\section{HEALTH RISK ANALYSIS}

Theoretical and practical journal. Start of publication: 2013.

4 issues per year

\section{EDITORIAL BOARD}

G.G. Onishchenko - Editor in Chief, Fellow of the Russian Academy of Sciences, DSc, Professor (Moscow, Russia) N.V. Zaitseva - Deputy Chief Editor, Fellow of the Russian Academy of Sciences, DSc, Professor (Perm, Russia) I.V. May - Executive Secretary, DSc, Professor (Perm, Russia)

\section{EDITORS}

S.L. Avaliani - DSc, Professor (Moscow, Russia)

A.B. Bakirov - DSc, Professor (Ufa, Russia)

E.N. Belyaev - corresponding member of RAS, DSc, Professor (Moscow, Russia)

V.M. Boev - DSc, Professor, (Orenburg, Russia)

I.V. Bragina -DSc (Moscow, Russia)

R.V. Buzinov - DSc (Arkhangelsk, Russia)

I.V. Bukhtiyarov - corresponding member of RAS, DSc,

Professor (Moscow, Russia)

V.B. Gurvich - DSc (Ekaterinburg, Russia)

I. Dardynskaia - DSc, Professor (Chicago, USA)

MA. Zemlyanova - DSc (Perm, Russia)

U.I. Kenesariev - DSc, Professor, corresponding member of the Academy of Medical Sciences of Kazakstan (Almaty, Kazakstan)

T. Cronberg - DSc in Ec., DSc in Tec., Member of the European Parliament from Finland. (Ruveslahti, Finland) S.V. Kuz'min - DSc, Professor (Ekaterinburg, Russia)

V.V. Kutyrev - Fellow of the Russian Academy of Sciences, DSc, Professor (Saratov, Russia)

V.R. Kuchma - corresponding member of RAS, DSc, Professor, (Moscow, Russia)

A.V. Mel'tser - DSc, Professor (St.-Petersburg, Russia)

A.Ya. Perevalov - DSc, Professor (Perm, Russia)

Y.P. Pivovarov - Fellow of RAS, DSc, Professor (Moscow, Russia)

A.Yu. Popova - DSc, Professor (Moscow, Russia)

V.N. Rakitskiy - Fellow of RAS, DSc, Professor, (Moscow, Russia)

S.I. Savelyev - DSc, Professor (Lipetsk, Russia)

P. Spencer - PhD, FRCPath Professor Department of neurology

(Portland, USA)

V.F. Spirin - DSc, Professor (Saratov, Russia) Director

A.Tsakalof - Professor of Medical Chemistry (Larissa, Greece)

V.A. Tutelyan - Fellow ofRAS, DSc, Professor (Moscow, Russia)

H.H. Hamidulina - DSc, professor, (Moscow, Russia)

V.A. Horoshavin - DSc, professor, (Perm, Russia)

S.A. Hotimchenko - DSc, professor (Moscow, Russia)

L.M. Shevchuk - PhD (Minsk, Belarus)

N.V. Shestopalov-DSc, Professor (Moscow, Russia)

P.Z. Shur - DSc, professor (Perm, Russia)

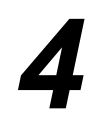

\section{October 2018 December}


To prepare and publish this issue, the metarials collected for the international conference "FOOD SAFETY AND RISK ANALYSIS"

held in Sochi on May 18-19 2017 have been applied

\section{PREVENTIVE MEDICINE:} URGENT ASPECTS OF RISK ANALYSIS

A.Yu. Popova

RISK ANALYSIS AS A STRATEGIC SPHERE IN PROVIDING FOOD PRODUCTS SAFETY

N.V. Zaitseva

ANALYSIS OF POPULATION HEALTH RISKS IN THE RUSSIAN FEDERATION CAUSED BY FOOD PRODUCTS CONTAMINATION

LEGAL ASPECTS OF RISK ASSESSMENT

L.N. Osaulenko PROVISION OF FOOD SAFETY AND CONSUMER RIGHTS PROTECTION IN THE EURASIAN ECONOMIC UNION LAW

SCIENTIFIC AND METHODICAL APPROACHES TO RISK ANALYSIS IN HYGIENE AND EPIDEMIOLOGY

Yu.A. Rakhmanin, R.I. Mikhailova FOOD RISKS ANALYSIS AND WATER SAFETY

P.Z. Shur, N.V. Zaitseva HEALTH RISK ASSESSMENT WHEN GIVING GROUNDS FOR HYGIENIC CRITERIA OF FOOD PRODUCTS SAFETY

RISK ASSESSMENT PRACTICE IN HYGIENIC AND EPIDEMIOLOGICAL STUDIES

Nguyen Thi Trung Thu, Le Thi Thuy Dung, Le Thi Tuyet NUTRITIONAL STATUS: THE TRENDS OF PRESCHOOL CHILDREN AGED 10-60 MONTHS IN THE NORTH OF VIETNAM

A.M. Yambulatov, O.Yu. Ustinova HYGIENIC ASSESSMENT OF ENVIRONMENTAL FACTORS THAT CAUSE INSUFFICIENT PROVISION WITH VITAMINS AMONG PRE-SCHOOL CHILDREN

G.F. Mukhammadiyeva, D.O. Karimov, O.V. Dolgikh, A.V. Krivtsov, A.A. Mazunina GENETICALLY MODIFIED FOOD PRODUCTS: PECULIARITIES OF GENETIC IDENTIFICATION
ПРОФИЛАКТИЧЕСКАЯ МЕДИЦИНА: АКТУАЛЬНЫЕ АСПЕКТЫ АНАЛИЗА РИСКА ЗДОРОВЬЮ

4 А.Ю. Попова АНАЛИЗ РИСКА - СТРАТЕГИЧЕСКОЕ НАПРАВЛЕНИЕ ОБЕСПЕЧЕНИЯ БЕЗОПАСНОСТИ ПИЩЕВЫХ ПРОДУКТОВ

13 Н.В. Зайцева АНАЛИЗ РИСКОВ ДЛЯ ЗДОРОВЬЯ НАСЕЛЕНИЯ РОССИЙСКОЙ ФЕДЕРАЦИИ, ОБУСЛОВЛЕННЫХ ЗАГРЯЗНЕНИЕМ ПИЩЕВЫХ ПРОДУКТОВ

\section{ПРАВОВЫЕ АСПЕКТЫ ОЦЕНКИ РИСКА}

24 Л.Н. Осауленко ОБЕСПЕЧЕНИЕ БЕЗОПАСНОСТИ ПИЩЕВОЙ ПРОДУКЦИИ И ЗАЩИТЫ ПРАВ ПОТРЕБИТЕЛЕЙ В ПРАВЕ ЕВРАЗИЙСКОГО ЭКОНОМИЧЕСКОГО COЮ3А

НАУЧНО-МЕТОДИЧЕСКИЕ ПОДХОДЫ К АНАЛИЗУ РИСКА В ГИГИЕНЕ И ЭПИДЕМИОЛОГИИ

31 Ю.А. Рахманин, Р.И. Михайлова АНАЛИЗ ПИЩЕВЫХ РИСКОВ И БЕЗОПАСНОСТЬ ВОДНОГО ФАКТОРА

43 П.З. Шур, Н.В. Зайцева ОЦЕНКА РИСКА ЗДОРОВЬЮ ПРИ ОБОСНОВАНИИ ГИГИЕНИЧЕСКИХ КРИТЕРИЕВ БЕЗОПАСНОСТИ ПИЩЕВЫХ ПРОДУКТОВ

\section{ПРАКТИКА ОЦЕНКИ РИСКА} В ГИГИЕНИЧЕСКИХ И ЭПИДЕМИОЛОГИЧЕСКИХ ИССЛЕДОВАНИЯХ

57 Нгуен Ти Трунг Ту, Ле Тхи Туй Дунг, Ле Тхи Туйет ОСОБЕННОСТИ ПИЩЕВОГО СТАТУСА ДЕТЕЙ СЕВЕРНОГО ВЬЕТНАМА В ВОЗРАСТЕ ОТ 10 МЕСЯЦЕВ ДО 5 ЛЕТ

66 А.М. Ямбулатов, О.Ю. Устинова ГИГИЕНИЧЕСКАЯ ОЦЕНКА ФАКТОРОВ СРЕДЫ ОБИТАНИЯ, ФОРМИРУЮЩИХ НАРУШЕНИЯ ОБЕСПЕЧЕННОСТИ ВИТАМИНАМИ ДЕТЕЙ ДОШКОЛЬНОГО ВОЗРАСТА

75 Г.Ф. Мухаммадиева, Д.О. Каримов, О.В. Долгих, А.В. Кривиов, А.А. Мазунина ОСОБЕННОСТИ ГЕНЕТИЧЕСКОЙ ИДЕНТИФИКАЦИИ ГЕНЕТИЧЕСКИ МОДИФИЦИРОВАННЫХ ИСТОЧНИКОВ ПИЩИ 
I.P. Saldan, O.I. Shved, B.A. Balandovich, A.S. Nagornyak, O.N. Mazko, O.G. Makarova, S.P. Filippova, O.V. Zhukova, N.Yu. Potseluev ASSESSMENT OF RISKS CAUSED BY IMPACTS EXERTED ON A HUMAN BODY BY NITRATES CONTAINED IN FOOD PRODUCTS

A.G. Setko, J.K. Mryasova, A.V. Turin RISK OF HEALTH DISORDERS IN CHILDREN CASUED BY CONSUMPTION OF CONTAMINATED FOOD PRODUCTS

A.A. Kuznetsov, A.N. Matrosov, A.M. Porshakov,

A.A. Sludsky, A.A. Kovalevskaya, V.P. Toporkov PRINCIPLES OF CARTOGRAPHIC DIFFERENTIATION AND EPIDEMIOLOGIC ZONING OF NTURAL PLAGUE FOCI APPLIED TO ASSESS AND MINIMIZE POPULATION HEALTH RISKS

\section{RISK MANAGEMENT. RISK COMMUNICATION}

I.V. May, N.A Lebedeva-Nesevrya, A.O. Barg STRATEGY AND TACTICS FOR BUILDING UP EFFICIENT RISK-COMMUNICATIONS IN THE SPHERE OF FOOD PRODUCTS SAFETY

D. Petrova, R. Garcia-Retamero HOW TO EFFECTIVELY COMMUNICATE RISKS TO DIVERSE CONSUMERS

N.V. Tyshko, E.O. Sadykova GENETICALLY MODIFIED FOOD PRODUCTS: DEVELOPMENT OF SAFETY ASSEESSMENT SYSTEM IN RUSSIA

N.N. Ivanova, L.M. Khomich EXPERIENCE OF BUSINESS COMMUNITY ON HOW TO DETECT AND STOP MARKET DISTRIBUTION OF JUICES NOT CONFORMING TO LEGAL REQUIREMENTS

\section{SCIENTIFIC REVIEWS}

I.V. Gmoshinski, V.A. Shipelin, S.A. Khotimchenko NANOMATERIALS IN FOOD PRODUCTS AND THEIR PACKAGE: COMPARATIVE ANALYSIS OF RISKS AND ADVANTAGES

NEW RF LEGAL, REGULATORY, AND METHODICAL DOCUMENTS

IN THE HEALTH RISK ANALYSIS SPHERE
81 И.П. Салдан, О.И. Швед, Б.А. Баландович, А.С. Нагорняк, О.Н. Мазко, О.Г. Макарова, С.П. Филиппова, О.В. Жукова, Н.Ю. Поиелуев ОЦЕНКА УРОВНЕЙ РИСКОВ ПРИ ВОЗДЕЙСТВИИ НА ОРГАНИЗМ ЧЕЛОВЕКА НИТРАТНОГО КОМПОНЕНТА ПИЩЕВОГО РАЦИОНА

89 А.Г. Сетко, Ж.К. Мрясова, А.В. Тюрин РИСК РАЗВИТИЯ ОТКЛОНЕНИЙ В СОСТОЯНИИ ЗДОРОВЬЯ ДЕТСКОГО НАСЕЛЕНИЯ, СВЯЗАННЫЙ С УПОТРЕБЛЕНИЕМ КОНТАМИНИРОВАННЫХ ПРОДУКТОВ ПИТАНИЯ

96 А.А. Кузнеиов, А.Н. Матросов, А.М. Поршаков, А.А. Слудский, А. А. Ковалевская, В.П. Топорков ПРИНЦИПЫ КАРТОГРАФИЧЕСКОЙ ДИФФЕРЕНЦИАЦИИ И ЭПИДЕМИОЛОГИЧЕСКОГО РАЙОНИРОВАНИЯ ПРИРОДНЫХ ОЧАГОВ ЧУМЫ ДЛЯ ЗАДАЧ ОЦЕНКИ И МИНИМИЗАЦИИ РИСКОВ ЗДОРОВЬЮ НАСЕЛЕНИЯ

\section{ИНФОРМИРОВАНИЕ О РИСКАХ. УПРАВЛЕНИЕ РИСКАМИ}

105 И.В. Май, Н.А. Лебедева-Несевря, А.О. Берг СТРАТЕГИЯ И ТАКТИКА ПОСТРОЕНИЯ ЭФФЕКТИВНЫХ РИСК-КОММУНИКАЦИЙ В СФЕРЕ БЕЗОПАСНОСТИ ПИЩЕВОЙ ПРОДУКЦИИ

114 Д. Петрова, Р. Гариия-Ретамеро ЭФФЕКТИВНОЕ ИНФОРМИРОВАНИЕ О РИСКАХ РАЗЛИЧНЫХ ГРУПП ПОТРЕБИТЕЛЕЙ

119 Н.В. Тышко, Э.О. Садыкова ГЕННО-ИНЖЕНЕРНО-МОДИФИЦИРОВАННАЯ ПИЩЕВАЯ ПРОДУКЦИЯ: РАЗВИТИЕ РОССИЙСКОЙ СИСТЕМЫ ОЦЕНКИ БЕЗОПАСНОСТИ

127 Н.Н. Иванова, Л.М. Хомич ОБ ОПЫТЕ БИЗНЕС-СООБЩЕСТВА ПО ВЫЯВЛЕНИЮ И ПРЕКРАЩЕНИЮ ОБРАЩЕНИЯ НА РЫНКЕ СОКОВОЙ ПРОДУКЦИИ, НЕ СООТВЕТСТВУЮЩЕЙ ТРЕБОВАНИЯМ ЗАКОНОДАТЕЛЬСТВА

\section{АНАЛИТИЧЕСКИЕ ОБЗОРЫ}

133 И.В. Гмочинский, В.А. Шипелин, С.А. Хотимченко НАНОМАТЕРИАЛЫ В ПИЩЕВОЙ ПРОДУКЦИИ И ЕЕ УПАКОВКЕ: СРАВНИТЕЛЬНЫЙ АНАЛИЗ РИСКОВ И ПРЕИМУЩЕСТВ

142 НОВЫЕ ЗАКОНОДАТЕЛЬНЫЕ, НОРМАТИВНЫЕ И МЕТОДИЧЕСКИЕ ДОКУМЕНТЫ РОССИЙСКОЙ ФЕДЕРАЦИИ В СФЕРЕ АНАЛИЗА РИСКА ЗДОРОВЬЮ 
UDC $613.26 ; 614.31$

DOI: $10.21668 /$ health.risk/2018.4.01.eng

Read

online

\title{
RISK ANALYSIS AS A STRATEGIC SPHERE IN PROVIDING FOOD PRODUCTS SAFETY
}

\author{
A.Yu. Popova \\ Federal Service for Surveillance on Consumer Rights Protection and Human Wellbeing, 18/5 and 7, \\ Vadkovskiypereulok, Moscow, 127994, Russian Federation
}

The paper dwells on basic issues related to providing food products safety with methodology of population health risk assessment and management under exposure to biological substances, chemicals, or hazardous physical factors of consumer goods. It is shown that Russia, just like many countries all over the world, is facing some global challenges now, in the beginning of the 21st century. These challenges are to be understood and estimated, and efficient measures are to be taken to overcome them. Among such challenges we can mention invention of new materials with poorly examined hygienic properties, increasing variety of technologies in food production, open borders for food products transferring etc.

Population in the Russian Federation is practically completely provided with access to sufficient quantities of food. However, there are still risks related to imbalanced nutrition and unsafe food products. Sanitary-epidemiologic surveillance is provided with a powerful and well-structured organization and functional system which allows to eliminate risks efficiently. Over 7000 sanitary-epidemiologic parameters of food products are subject to control and surveillance in the RF. More than 3000 standards are harmonized within the Eurasian Economic Union regulations. A lot of work is done on developing laboratory control over food products quality. Risk-oriented control over quality and safety of food products is implemented. New approaches to assessing risks related to food products are being developed. New techniques fully incorporate conventional principles of risk assessment and relevant toxicological and epidemiological data and allow to substantiate viewpoints that the Russian Federation has on issues related to hygienic standardization for some biological and chemical agents in food products. Procedures for analysis of new technologies are being developed actively.

There are some strategic areas in development of risk analysis methodology; they are creation of public information databases on food products quality and risks related to them; development of risk prediction procedures including genetic analysis techniques, mathematical modeling, medical and biological research; improved procedures for prediction of individual health risks with development of personified programs for prophylaxis of diseases; development of procedures for obtaining evidence of damage done due to health risk realization; creation of risk-oriented models for managing food products quality and creation of global information field for risk communications.

Key words: hazard factor, food products, sanitary-epidemiologic surveillance, health risk assessment, development strategy.

To prevent diseases caused by malnutrition and unsafe food is one of the most important tasks to be solved by the RF state authorities in general and sanitary-epidemiologic surveillance bodies in particular.

Just as many other countries in the world, Russia faced certain global challenges in the beginning of the 21 st century; these challenges are to be recognized, assessed and dealt with in the most efficient way. The challenges are variable; they are caused by globalization, borders open for goods and services, an increased variety of technologies and raw materials applied in food products manufacturing, much greater volumes of uncontrollable or poorly controllable trade, first of all, electronic one, state surveillance becoming more democratized etc. (Figure 1). 


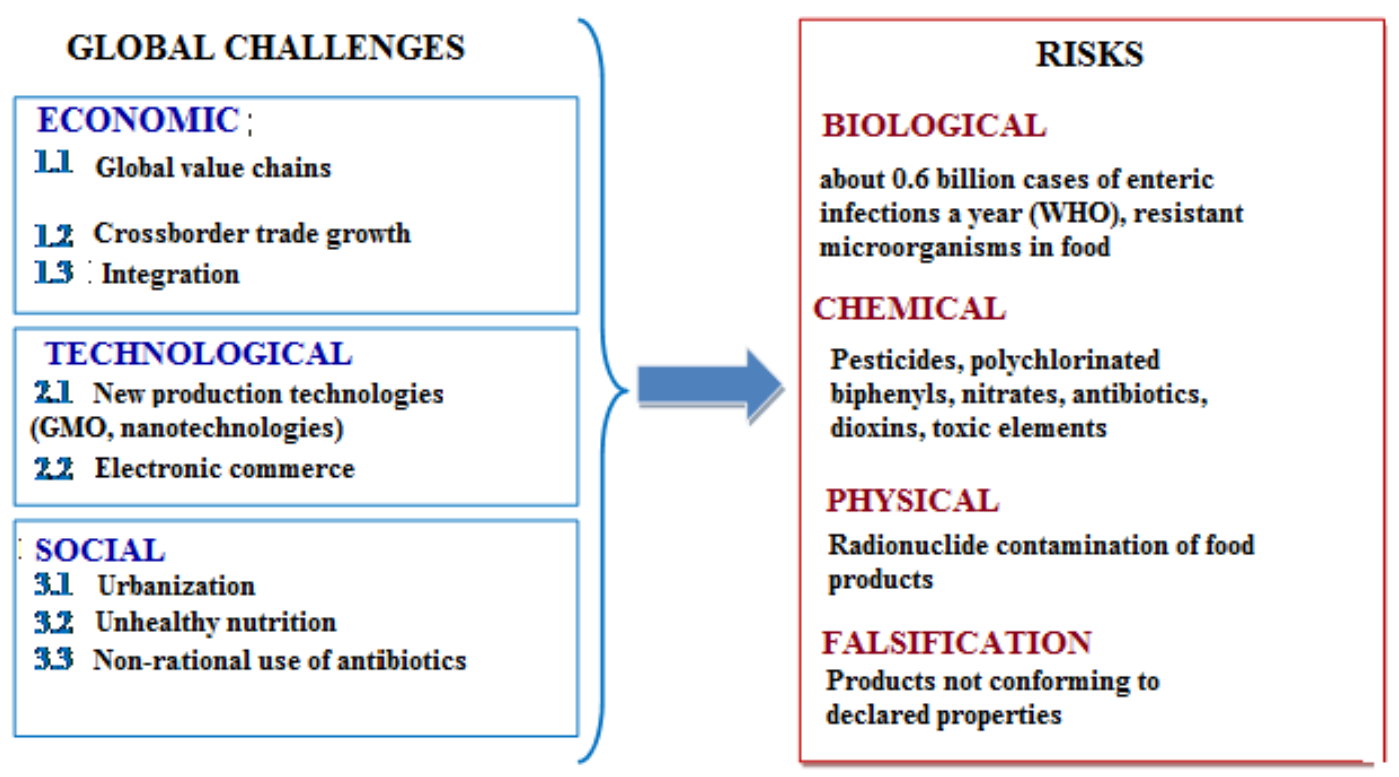

Figure 1. Global challenges that cause consumer health risks

Control and surveillance activities performed by state authorities and scientific research accomplished in many countries allowed to detect biological agents and toxic chemical elements in food raw materials and/or food products; these hazardous substances occurred there in concentrations higher than those fixed in safety standards [1-6]. Biological, chemical, and radiation risk factors can occur in various sections in food chains. As a rule, biological contamination of food results from violated requirements to a technological process or workers' personal hygiene [7-9]. Hazardous chemicals such as toxic metals, dioxins, or polychlorinated biphenyls (PCBs) can accidently occur in food products due to environmental pollution when air, water, and soils are contaminated. Chemicals that are contained in technological equipment can be released from materials this equipment is made of and which contact food etc. [4-6, 10, 11]. Radiation contamination most frequently occurs due to application of unsafe raw materials or environmental contamination $[12,13]$. Microorganisms in food products that are re- sistant to antibiotics are another serious problem [14-16].

Food products contamination causes elevated risks for health of consumers from various age and social groups. Chemical factors (pesticides, polychlorinated biphenyls, nitrates, antibiotics, dioxins, heavy metals, etc.) causes risks of digestive pathologies, as well as pathologies in the nervous and immune systems, blood pathologies etc. Biological risks can lead to infectious as well as some somatic diseases. As per data taken from the World Health Organization (WHO) report on global burden of foodborne diseases, low quality or unhealthy food annually causes almost 600 million enteric infections cases ${ }^{1}$. As it is outlined in the report, about $30 \%$ of all the death cases caused by foodborne diseases are registered among children under 5 , in spite of this age group accounting for only $9 \%$ of the total world population. The WHO experts note that in Europe more than 23 million people annually fall ill due to unsafe food consumption and it leads to 5,000 death cases.

\footnotetext{
${ }^{1}$ WHO estimates of the global burden of foodborne diseases: foodborne disease burden epidemiology reference group 2007-2015 [web-source] // World Health Organization. - URL: http://www.who.int/foodsafety/publications/foodborne_disease/fergreport/en/ (date of visit June 01, 2018).
} 
The Russian Federation faces similar problems related to unsafe food as developed countries do. As for providing population with sufficient quantity of food, we can state that this issue has practically been solved. But there are still risks associated with nutrition being balanced and food products being safe. Food products are often falsified, and it is a critical problem existing in the Russian Federation. Trade in food stuffs and volumes of imported food products have grown significantly over recent years; imports often include goods that don't conform to national hygienic standards and it makes issues related to food trade globalization and growing volumes of imports more and more vital. In 2017 The Federal Service for Surveillance over Consumer Rights Protection and Human Wellbeing examined more than 290 thousand food samples within monitoring over food products safety; samples were examined to check their conformity with hygienic standards as per chemical contaminants concentrations. A share of samples not conforming to the standards amounted to $0.44 \%$. 1,192,000 samples were examined to check their microbiological safety; $4.03 \%$ out of them didn't conform to hygienic standards.

The country still faces serious challenges related to healthy nutrition as more than $90 \%$ people living in the RF have excessive quantity of simple carbohydrates in their daily ration. As a result, more than half Russians who are older than 30 suffer from overweight and obesity and it can lead to cardiovascular diseases, malignant neoplasms, and pancreatic diabetes. In 2016 primary morbidity with obesity among adults older than 18 amounted to 285.85 per 100,000 adult people (it was 284.85 in $2015 ; 188.05$ in $2014 ; 161.84$ in 2013; 123.56 in 2012$)^{2}$. Vitamins and microelements are not consumed in sufficient quantities in many Russian regions.

Hygienic and social problems related to providing population with healthy and safe nutrition have been recognized and discussed at various levels, including parliamentary one ${ }^{3}$; these discussions led to approval on some strategic documents such as "The RF Food Security Doctrine" ${ }^{4}$, "Fundamentals of the state policy related to healthy nutrition of population for the period up to $2020^{\prime \prime}$, "The concept for developing internal food aid in the Russian Federation" ${ }^{6}$, "The Strategy for improving food products quality in the Russian Federation for the period up to $2030^{\prime \prime}$. All these documents state that the state policy related to healthy nutrition has the following key targets: to preserve and to improve population health, and to prevent diseases associated with unsafe products, insufficient and unbalanced nutrition.

To provide nutrition safety in the RF, the following priority tasks are to be solved:

- providing food security in the country and making safe and qualitative food products available for all social layers of the population; - creating a strategic system for providing population with food products in conformity

\footnotetext{
${ }^{2}$ On sanitary-epidemiologic welfare of the population in the Russian Federation in 2017: The State report. - M.: The Federal Service for Surveillance over Consumer Rights Protection and Human Well-being, 2018. - 268 p.

${ }^{3}$ On legal measures and techniques for preventing distribution of counterfeit, falsified, and low quality products in the Russian Federation: Recommendations given on the Parliamentary hearings on February 14, 2006 [web-source] // The RF State Duma Committee for economic policy and entrepreneurship: Official web-site. - URL: http://www.duma.gov.ru/econpolicy/parlam/140206/index.shtml (date of visit June 01, 2018).

${ }^{4}$ On Approval of the RF Food Security Doctrine: The RF President Order issued on January 30, 2010 No. 120 [websource] // The CIS states legislation. - URL: http://base.spinform.ru/show_doc.fwx?rgn=30398 (date of visit June 01, 2018).

${ }^{5}$ On Approval of the Fundamentals of the RF state policy related to healthy nutrition of population for the period up to 2020: the RF Government Order issued on October 25, 2010 No.1873-p [web-source] // GARANT: information and legal portal. - URL: http://www.garant.ru/products/ipo/prime/doc/12079847/ (date of visit June 01, 2018).

${ }^{6}$ On Approval of the Concept for developing internal food aid in the Russian Federation: the RF Governmental Order issued on July 03, 2014 No.1215-p [web-source] // KonsultantPlus. - URL: http://www.consultant.ru/document/cons_doc_ LAW_165323/ (date of visit June 01, 2018).

${ }^{7}$ On Approval of the Strategy for improving food products quality for the period up to 2030: the RF Government Order issued on June 29, 2016 No.1364-p [web-source] // The RF Government official web-site. - URL: http://government.ru/docs/23604/ (date of visit June 01, 2018).
} 
with scientifically grounded physiological nutrition standards;

- minimizing threats associated with intolerable risks caused by chemical and microbiological factors of food products;

- stimulating development of manufacturing and market distribution of qualitative food products;

- stimulating activities aimed at making people inclined to pursue healthy life style, including healthy nutrition;

- protecting vulnerable population cohorts including pre-school and school children;

- preventing and decreasing diseases associated with insufficient and unsafe nutrition including a $30 \%$ decrease in prevalence of obesity and primary hypertension.

If all the Eastern European and Central Asian countries join their efforts fighting basic critical problems related to food products safety and quality, it will allow to reduce hazards of alimentary and infectious diseases among population and will become an essential component in achieving strategic goals fixed in the UN program 'United Nation Decade of Action on Nutrition"

Rospotrebnadzor, acting within its authority, is responsible for products safety; the organization applies such tools for managing health risks as administrative and criminal liability for violation of sanitary legislation; withdrawal of products from the market; setting limits to spheres of application; relevant marking of products; informing consumers about health risks; assigning products into risky deliveries category9. Today, The State Sanitary and Epidemiologic Surveillance is equipped with a powerful and well-structured organizational and functional system. More than 7 thousand sanitary-epidemiologic parameters are controlled in the RF and the Customs Union member states in the sphere of food raw materials and food products safety and more than 3 thousand out of them were harmonized when a unified legislative base for the Customs Union Agreement was created ${ }^{10}$.

In 2017 the RF Government approved on an action program for implementing the Strategy for improving food products quality in the country for the period up to $2030^{11}$. This action program included some draft regulatory documents aimed at harmonizing national legislation with the Eurasian Economic Union acts as regards determination of food products quality, principles of healthy nutrition, making improvements into product marking and control over it. Information resources that provide population with data concerning consumer rights protection, quality and safety of goods have been developed further, and people are constantly informed about food products safety and quality and principles of healthy nutrition.

Experts are working out identification criteria (markers) for food products that can help to detect falsification and that can be used in analytical techniques for detecting falsified food products; laboratory control over food products quality is being improved, especially regarding food manufactured with biotechnologies and state registration of food products $[17,18]$; a risk-oriented approach to state control (surveillance) has been implemented in the sphere of providing food products safety and quality [19].

Methodology of health risk analysis is considered to be a priority scientific instru-

\footnotetext{
${ }^{8}$ United Nation decade of Action on Nutrition, work program for 2016-2025 [web-source] // The World Health Organization. - URL: http://www.who.int/nutrition/decade-of-action/workprogramme-2016to2025/ru/ (date of visit June 01, 2018).

${ }^{9}$ The Provisions on the Federal Service for Surveillance over Consumer Rights Protection and Human Well-being: The RF Governmental Order issued on June 30, 2004. No. 322 (last edited as the RF Government Order dated May 21, 2013 No. 428 ) [websource] // GARANT: information and legal portal. - URL: http://base.garant.ru/12136005/ (date of visit June 01, 2018).

${ }^{10}$ The Customs Union Agreement on sanitary measures [web-source] // the Eurasian Economic Commission. - URL: http://www.tsouz.ru/MGS/mgs-11-12-09/Pages/mgs25-28-pril1 aspx (date of visit June 01, 2018).

${ }^{11}$ On Approval of the action program for implementing the Strategy for improving food products quality in the country for the period up to 2030 approved by the RF Government Order dated June 29, 2016 No. 1364-p: the RF Government Order dated April 19, 2017 No, 738-p [web-source] // KonsultantPlus. - URL: http://www.consultant.ru/document/cons_doc_LAW_215997/ (date of visit June 01, 2018).
} 
ment that allows to solve issues related to control over raw materials and food products safety at the state level [20]. At present Russia has all the necessary resources to implement the most up-to-date approaches to assessing product risks. 800 test laboratory centers that operate within Rospotrebnadzor system are certified by the state (including 8 centers certified within DAkks system). They perform instrumental research in order to determine actual quality and safety of food products. Over several decades the Federal Information Fund for social and hygienic monitoring (FIF SHM) has been accumulating not only data on products parameters and environmental objects but also medical and demographic data (birth rate, mortality, morbidity with basic nosologies per age groups and regions, results of preventive examinations performed on children and teenagers etc.). This system integrates data obtained during toxicological monitoring performed in every region in Russia. The FIF SHM, together with the results of control and surveillance activity, provides information grounds for risk assessment (hazard identification, determination of "dose - effect" dependence, exposure assessment).

Experts are creating new approaches to assessing product risks including those that incorporate mathematic modeling for risk evolution over time [21]. And these new approaches fully implement conventional risk assessment principles and relevant toxicological and epidemiologic data. Application of these new approaches allows to substantiate opinions expressed by the RF on hygienic regulation of certain biological and chemical agents in food products and to do it solely in order to protect consumers' health (Table). For example, when justifying maximum permissible levels of tetracycline, experts applied a mathematical model that described changes in intestinal microflora balance and assessed risks of related pathologies [22]. When a hygienic standard for ractopamine was developed, experts modeled evolution of risk during an average life span under actual exposure taking into account excretion of ractopamine out of a body [23].

Experts are actively developing techniques that allow to analyze new technologies including genetic engineering, nanomaterials application, use of bacteriophages to prolong shelf-life or to increase food products safety. Such technologies are widely used both in Russian and all over the world, and their potential use for people's health is huge. However, potential hazards related to these technologies make it necessary to objectively assess risks associated with their application $[24,25]$. When considering risks associated with new technologies, it is necessary to reach balance between unconditional provision of safety for this generation and cones-

Table

Russian hygienic standards substantiated with risk assessment that differ from international ones

\begin{tabular}{|c|c|c|c|}
\hline Hazard factor & Food products & $\begin{array}{l}\text { Russian standard substantiated as per } \\
\text { risk criteria }\end{array}$ & $\begin{array}{l}\text { Codex Alimentarius } \\
\text { Commission standard }\end{array}$ \\
\hline Ractopamine & Meat products & Total absence & $0-0.01 \mathrm{mg} / \mathrm{kg}$ \\
\hline $\begin{array}{l}\text { L.Monocy- } \\
\text { togenes }\end{array}$ & $\begin{array}{l}\text { Meat products, } \\
\text { fish, dairy } \\
\text { products }\end{array}$ & $\begin{array}{c}\text { Absence } \\
\text { in } 25 \text { grams of a products }\end{array}$ & $\begin{array}{c}100 \mathrm{CFU} / \mathrm{g} \\
\text { (for products distributed } \\
\text { on market) }\end{array}$ \\
\hline Tetracycline & Meat products & $10 \mu \mathrm{g} / \mathrm{kg}(0.01 \mu \mathrm{g} / \mathrm{kg})$ & from $<0.1$ to $1.2 \mu \mathrm{g} / \mathrm{kg}$ \\
\hline Nitrates & $\begin{array}{l}\text { Fruit and vege- } \\
\text { tables }\end{array}$ & $\begin{array}{c}\text { Salad, fresh onion - up to } 4,000 \mu \mathrm{g} / \mathrm{kg} \\
\text { Potatoes - } 250 \mu \mathrm{g} / \mathrm{kg} \\
\text { Tomatoes - up to } 300 \mu \mathrm{g} / \mathrm{kg} \\
\text { Carrots - up to } 400 \mu \mathrm{g} / \mathrm{kg} \\
\text { Cucumbers - up to } 400 \mu \mathrm{g} / \mathrm{kg} \\
\text { Cabbage }-900 \mu \mathrm{g} / \mathrm{kg} \\
\text { Beetroot }-1,400 \mu \mathrm{g} / \mathrm{kg}\end{array}$ & $\begin{array}{l}\text { Salad, fresh onion - } \\
\text { up to } 4,500 \mu \mathrm{g} / \mathrm{kg}\end{array}$ \\
\hline
\end{tabular}




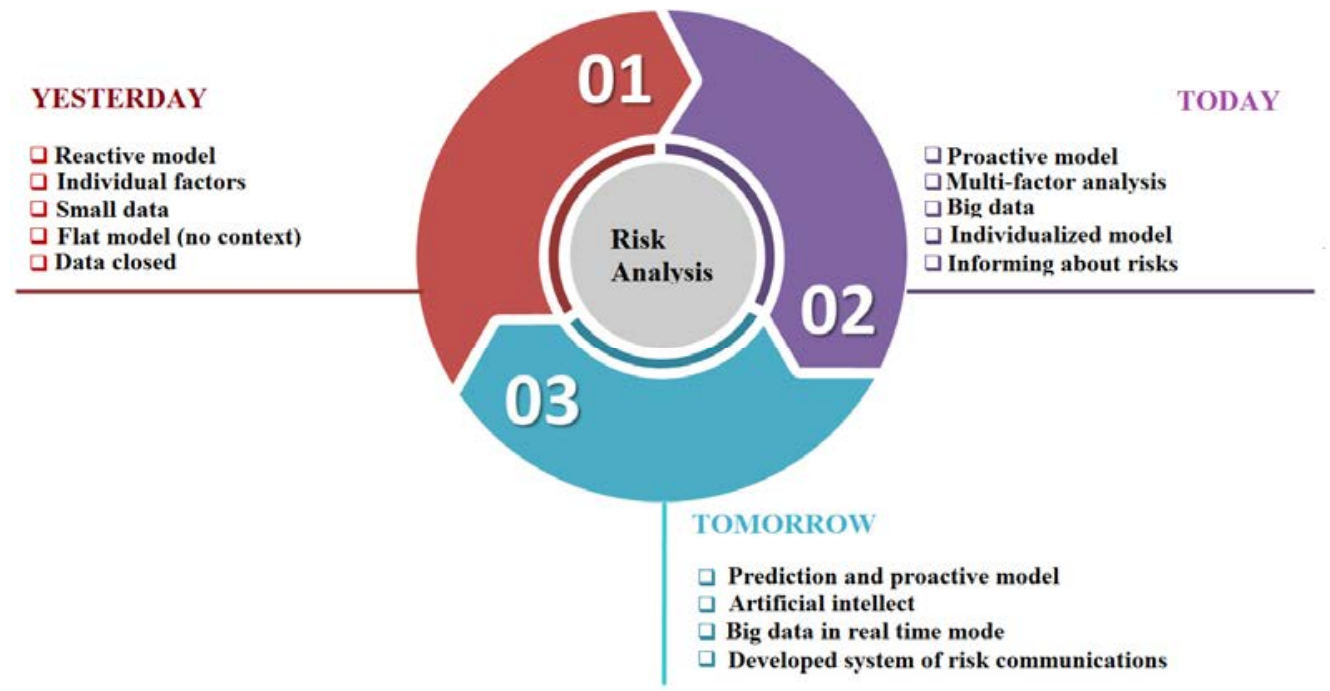

Figure 2. Methodology of consumer health risks assessment: basic components

quent ones, on the one hand, and an urgent need to provide progress in manufacturing and distributing products with a lot of useful consumer properties, on the other hand.

Criteria that underlie safety assessment are to be clear and they are to be communicated to people so that the latter could participate in the process at its early stages. It is necessary to openly and clearly communicate risks to all the concerned parties that can be influenced by food-related hazards. Information exchange will help to organize a profound dialogue between all the parties (consumers, manufacturers, and distributors) in risk analysis process and will allow them to equally participate in it [26]. As regards the above-mentioned issue, the Russian Federation strictly adheres to abandoning oneside administratively-oriented informing and to implementing a dialogue, risk communications, and searching for a social consensus in the food safety sphere [27, 28].

However, Russia is still an integral part of the Eurasian Economic Union even when protecting interests of the country citizens; and the Eurasian Economic Union has declared a strategic goal to join efforts for protecting consumers' health and rights on the overall territory of the unified economic space and consumer market. The Council that comprises heads of competent authorities responsible for sanitary and epidemi- ologic welfare of the population living in the EAEU member states was created and has been operating quite successfully ever since. Most urgent and acute issues related to consumer products safety are constantly being discussed; all the concerned parties are looking for consensus and mutually beneficial solutions.

Development of risk assessment methodology is a well-known and very promising way to reach a new level in predicting threats and hazards and taking efficient preventive actions that will help to preserve population health (Figure 2).

Russia takes active part in developing approaches to solving nutrition-related problems on the international level. The Russian Federation constantly participates in activities performed by international organizations (the WHO, the FAO, the UNICEF, the UNEP etc.) when considering nutritionrelated issues as well as those related to food products quality and safety. The country has declared the following priorities in its policy for assisting international development at regional and global level: assistance in providing food security and safe nutrition as well as agricultural development of states that are recipients of this assistance. Russia makes a considerable contribution into global food security cooperating with international organizations. 
Goals and tasks fixed in the UN decade of Action on Nutrition program in nutrition sphere are becoming integral components of national agenda and programs all over the world, and in the Russian Federation as well. Population health should always remain a top priority. When solving issues related to providing people with sufficient nutrition, one should prevent any increase in health risks caused by microbiological, chemical, or radiation contaminants in food products. Up-todate tools for risk assessment should become a solid base for building up national strategies and plans aimed at struggling against malnutrition in all its forms as well as at providing food safety and quality. In this relation it seems strategically significant to develop methodology for health risk assessment completing the following:

- to unify national information databases and to create global ones that contain information on food products quality and related risks;

- to develop risk prediction techniques including those based on application of genetic and mathematic modeling and biological analysis;

- to update methods for predicting individual health risks together with creating personified programs of medical and preventive support;

- to develop methodology for creating a system of evidence that proves damage to health in case a health risk is realized;

- to create risk-oriented models for managing food products quality including those incorporating control and surveillance activities;

- to form a global information and communication field that contains data on foodrelated health risks for consumers; the field will provide relevant support to risk management actions.

We should further develop methodology for assessment and prediction of food-related risks, update techniques for managing such risks, and it will eventually allow us to achieve our primary goal, namely, to preserve population health and to provide more comfortable and safe living standards for people both in Russia and all over the world.

Funding. The research was not granted any sponsor support.

Conflict of interests. The authors state there is no any conflict of interests.

\section{References}

1. Milošković A., Đ Milošević., Radojković N., Radenković M., Đuretanović S., Veličković T., Simić V. Potentially toxic elements in freshwater (Alburnus spp.) and marine (Sardina pilchardus) sardines from the Western Balkan Peninsula: An assessment of human health risk and management. Science of the Total Environment, 2018, vol. 644, no. 10, pp. 899-906. DOI: $10.1016 /$ j.scitotenv.2018.07.041

2. Otero X.L., Tierra W., Atiaga O., Guanoluisab L.M., Nunesd T., Ferreira T.O., Ruales J. Arsenic in rice agrosystems (water, soil and rice plants) in Guayas and Los Ríos provinces, Ecuador. Science of The Total Environment Science, 2016, vol. 573, pp. 778-787.

3. Vejarano R., Siche R. Evaluation of biological contaminants in foods by hyperspectral imaging: A review. International Journal of Food Properties, 2017, vol. 20, pp. 1264-1297. DOI: 10.1080/10942912.2017.1338729

4. Liu Y., Liu G., Yuan Z., Liu H., Lam P.K.S Presence of arsenic, mercury and vanadium in aquatic organisms of Laizhou Bay and their potential health risk. Marine Pollution Bulletin, 2017, vol. 125 , no. $1-2$, pp. $176-185$.

5. Valikhov A.F. Contamination of milk and milk products with potentially hazardous substances. Molochnaya promyshlennost', 2017, no. 12, pp. 11-14 (in Russian).

6. Shumakova A.A., Povarova N.M., Rezaeva D.M., Gmoshinskii I.V. Soderzhanie svintsa, kadmiya, mysh'yaka i selena v moreproduktakh [Contents of $\mathrm{Pb}, \mathrm{Cd}, \mathrm{As}$, and $\mathrm{Se}$ in seafood]. Voprosy pitaniya, 2016, vol. 85, no. S2, pp. 40 (in Russian).

7. Fedorenko E.V., Kolomiets N.D. Dinamicheskii podkhod pri otsenke bezopasnosti pishchevoi produktsii [A dynamic approach in assessing food products safety]. Voprosy pitaniya, 2016, vol. 85, no. S2, pp. 37 (in Russian). 
8. Antonov A.E., Shiryaev D.S. Assessment of the hygienic risks of the food equipment - a composite part of the system for products safety management. Molochnaya promyshlennost', 2017, no. 6, pp. 30-31 (in Russian).

9. Momani W.A., Janakat S., Khatatbeh M. Bacterial contamination of table eggs sold in Jordanian markets. Pakistan Journal of Nutrition, 2017, vol. 17, no. 1, pp. 15-20.

10. Pivovarov Yu.P., Milushkina O.Yu., Tikhonova Yu.L., Aksenova O.I., Kalinovskaya M.V. Chemical pollution of baby food products in the Russian Federation. Gigiena i sanitariya, 2016, vol. 95, no. 8, pp. 707-711 (in Russian).

11. Li S.-Q., Ni H.-G., Zeng H. PAHs in polystyrene food contact materials: An unintended consequence. Science of the Total Environment, 2017, vol. 609, pp. 1126-1131. DOI: 10.1016/j.scitotenv.2017.07.262

12. Kenigsberg Ya.E., Tsybul'ko N.N. Radiation protection of Belarus population of after the Chernobyl disaster. Radiatsionnaya gigiena, 2014, vol. 7, no. 2, pp. 15-20 (in Russian).

13. Meshkov N.A. Late effects of dietary radiocesium intake in residents of territories contaminated with radionuclides following atmospheric nuclear testings in the Semipalatinsk Test Site. Radiatsiya i risk (Byulleten' Natsional'nogo radiatsionno-epidemiologicheskogo registra), 2017, vol. 26, no. 4, pp. 33-42 (in Russian).

14. McCrackin M.A., Helke K.L., Galloway A.M., Poole A.Z., Salgado C.D., Marriott B.P. Effect of Antimicrobial Use in Agricultural Animals on Drug-resistant Foodborne Campylobacteriosis in Humans: A Systematic Literature Review. Critical Reviews in Food Science and Nutrition, 2016, vol. 56, no. 13 , pp. 2115-2132.

15. Sheveleva S.A. Antimicrobial-resistant microorganisms in food as a hygienic problem. Gigiena i sanitariya, 2018, vol. 97, no. 4, pp. 342-354 (in Russian).

16. Qin S., Wang Y., Zhang Q., Deng F., Shen Z., Wu C. [et al.]. Report of ribosomal RNA methylase gene erm (B) in multidrug resistant Campylobacter coli. J. Antimicrob. Chemother, 2014, vol. 69, no. 4 , pp. 964-968.

17. Tutel'yan V.A., Nikityuk D.B., Khotimchenko S.A. Normative base for food quality and safety assessment. Russian Journal of Rehabilitation Medicine, 2017, no. 2, pp. 74-120 (in Russian).

18. Orobinskaya V.N., Limareva N.S. Kriterii bezopasnosti pishchevykh produktov, laboratornyi kontrol' za produktami, soderzhashchimi GMO [Criteria of food products safety, laboratory control over GMO-containing products]. Sovremennye nauchnye issledovaniya i razrabotki, 2017, vol. 10, no. 2, pp. 371-373 (in Russian).

19. Popova A.Yu., Zaitseva N.V., May I.V. Experience of methodological support and practical implementation of the risk-oriented model of sanitary-epidemiological surveillance in 2014-2017. Gigiena i sanitariya, 2018, vol. 97, no. 1, pp. 5-9 (in Russian).

20. Zaitseva N.V., Popova A.Yu., May I.V., Shur P.Z. Methods and technologies of health risk analysis in the system of state management under assurance of the sanitation and epidemiological welfare of population. Gigiena i sanitariya, 2015, vol. 94, no. 2, pp. 93-98 (in Russian).

21. Zaitseva N.V., Shur P.Z., May I.V., Kiryanov D.A. On the question of the application of the prediction of the evolution of health risk in hygienic assessments. Gigiena i sanitariya, 2016, vol. 95, no. 1, pp. 106-112 (in Russian).

22. Zaitseva N.V., Shur P.Z., Aminova A.I., Kiryanov D.A., Kamaltdinov M.R. To estimate the additional risk of diseases of the gastrointestinal tract associated with dysbiosis of the intestinal microflora due to the impact of tetracycline residues in foods. Zdorov'e naseleniya i sreda obitaniya, 2012, vol. 232, no. 7, pp. 46-48 (in Russian).

23. Onishchenko G.G., Popova A.Yu., Tutel'yan V.A., Zaitseva N.V., Khotimchenko S.A., Gmoshinskii I.V., Sheveleva S.A., Rakitskii V.N., Shur P.Z., Lisitsyn A.B., Kiryanov D.A. About the Human Health Safety Estimation of Ractopamine Intake Together with the Food. Vestnik Rossiiskoi akademii meditsinskikh nauk, 2013, vol. 68, no. 6, pp. 4-8 (in Russian).

24. Gmoshinskii I.V., Khotimchenko S.A. Nanotekhnologii v proizvodstve pishchevykh produktov: otsenka riskov [Nanotechnologies in food products manufacturing: risks assessment]. Voprosy pitaniya, 2014, vol. 83, no. S3, pp. 174 (in Russian). 
25. Eliseeva L.G., Yurina O.V. International trends in the production of gm food: risks and prospects. Mezhdunarodnaya torgovlya i torgovaya politika, 2015, vol. 2, no. 2, pp. 101-120 (in Russian).

26. Smith J., Ross K., Whiley H. Australian food safety policy changes from a "command and control" to an "outcomes-based" approach: Reflection on the effectiveness of its implementation. International Journal of Environmental Research and Public Health, 2016, vol. 13, no. 12, pp. 1218. DOI: 10.3390/ijerph13121218

27. Barg A.O., Lebedeva-Nesevrya N.A. Risk-communication as an effective way of producing the cumulative acceptability of human health risks. Zdorov'e naseleniya i sreda obitaniya, 2014, vol. 261, no. 12, pp. 9-11 (in Russian).

28. Bovay J. Demand for collective food-safety standards. Agricultural Economics (United Kingdom), 2017, vol. 48, no. 6, pp. 793-803. DOI: 10.1111/agec.12375

Popova A.Yu. Risk analysis as a strategic sphere in providing food products safety. Health Risk Analysis, 2018, no. 4, pp. 4-12. DOI: 10.21668/health.risk/2018.4.01.eng

Received: 12.10 .2018

Accepted: 15.11 .2018

Published: 30.12.2018 
UDC 613.2

DOI: $10.21668 /$ health.risk/2018.4.02.eng

\title{
ANALYSIS OF POPULATION HEALTH RISKS IN THE RUSSIAN FEDERATION CAUSED BY FOOD PRODUCTS CONTAMINATION
}

\author{
N.V. Zaitseva \\ Federal Scientific Center for Medical and Preventive Health Risk Management Technologies, 82 Monastyrskaya \\ Str., Perm, 614045, Russian Federation
}

\begin{abstract}
Analysis of population health risks related to food products is a most promising sphere for international cooperation between the Eurasian Economic Union (EAEU) member states and economically developed countries. And it is truly vital to harmonize key aspects of the process. Methodology of population health risk analysis is considered to be a basic tool for providing food products safety in the Russian Federation.

Harmonization takes place simultaneously with creation, development, and implementation of all the instruments related to risk analysis components in the Russian Federation: risk assessment, risk management, and informing about risks. In the EAEU countries and in the RF, experts apply evolution mathematical modeling to describe impacts exerted by dangerous chemicals and biological agents on functions of body organs and systems when they assess risks related to food products. Markers of exposure and effect together with epidemiologic models give information grounds for establishing regularities in relationships and calculation of parameters for consequent health risk assessment. Established regularities together with experience that was accumulated due to physiological processes modeling gave grounds for multi-level modeling of health risk evolution. Such models allow to predict negative effects both for critical organs and systems and a body as a whole.

Approaches have been tested when substantiating hygienic safety criteria for some food contaminants. New tasks are set; it is necessary to develop a regulatory basis for assessing health risks related to food contamination and property losses borne by a consumer due to such risks; to speed up development and implementation of harmonized risk-based quality standards as criteria of food safety for health and their application in control and surveillance activities; to improve information basis for health risk assessment and development of international cooperation on issues related to analyzing health risks caused by food products contamination.
\end{abstract}

Key words: risk assessment, risk management, mathematical modeling, food products, safety, cooperation.

Food safety in the Russian Federation is considered to be one of the basic factors that help to preserve its national sovereignty. It is also a most essential part of the demographic policy and a necessary condition for improving life quality of Russian citizens. The latter is a top strategic national priority and it can be achieved via guaranteeing high living standards. Procedures for population health risks analysis are considered in the RF to be a basic instrument for providing food products safety [1-5].

There is a multi-level system of legal regulations developed in the RF and the EAEU countries. It regulates health risks analysis including risks caused by food products contamination [6]. This system consists of such legal documents as the Customs Union Technical
Regulations and the RF Federal Laws. The RF Federal Law "On Technical Regulation"1 states that products safety, including food products, means absence of any intolerable risk for people's life and health. Requirements to products which include absence of intolerable risk are fixed in technical regulations.

Analysis of health risks for the RF population which are caused by food products contamination is performed within a legal framework existing in the RF and EAEU. This framework includes both legal and subordinate acts as well as regulatory and methodical documents. Legal documents are the Customs Union Technical Regulations (CU TR), such as, for example, "On food products safety", "TR for juice products made of fruit and vege-

(C) Zaitseva N.V., 2018

Nina V. Zaitseva - Academician of the Russian Academy of Sciences, Doctor of Medical Sciences, Professor, Scientific Director (e-mail: znv@fcrisk.ru; tel.: +7 (342) 237-25-34; ORCID: https://orcid.org/0000-0003-2356-1145).

${ }^{1}$ On technical regulation: The Federal Law No. 184-FL issued on December 27, 2002 [web-source] // KonsultantPlus. URL: http://www.consultant.ru/document/cons_doc_LAW_40241/ (date of visit September 16, 2018). 
tables", "On grain safety", "TR for fat and oil products" ${ }^{2}$ etc. The RF Government Regulation "On application of risk-oriented approach when organizing specific types of the state control (surveillance) activities and making alterations into some RF Government Regulations" ${ }^{3}$ issued on August 17, 2016 No. 806 (edited on March 30, 2017) is one of the most important subordinate acts in the sphere.

Analysis of health risks caused by food products is one of the most promising spheres for international cooperation between the Eurasian Economic Union (EAEU) member states and economically developed countries. And it is most essential to harmonize its key aspects $[7,8]$.

Health risk analysis is a process which consists of three components: risk assessment, risk management, and risk communications; therefore, all three components need to be harmonized but with allowance for peculiarities they all have. It is advisable to get better insight into harmonization of risk analysis systems, first of all, their legal aspects and key principles.

We analyzed experience in harmonizing risk assessment procedures accumulated in the European Union, and it allowed us to identify other critical components in the process: harmonization of health risk assessment techniques and criteria [9-11].

A key aspect here is harmonization of legislation in the risk analysis sphere. Such harmonization of legal grounds for analyzing risks of food products contamination should be based on convergence between legal regulation existing in the EAEU and the RF and standards fixed by the WTO and Codex Alimentarius Commission. There are a lot of positive examples in the field. Basic regulations fixed in laws "On Technical Regulation" which are adopted in the EAEU member states are almost completely harmonized with similar legal documents existing in the developed countries. Thus, in order to harmonize legal grounds existing in the EAEU countries with the WTO standards on sanitary and phytosanitary measures, basic principles and rules for sanitary and phytosanitary measures application were included into the Treaty on the EAEU dated May 29, 2014. However, a lot is left to be implemented. For example, to develop the Russian Federation legislation further, we need to introduce new legal regulations on risk analysis into the Law "On sanitary-epidemiologic welfare of the population" ${ }^{4}$; these new regulations are to be harmonized with the legislative practices existing in Europe.

Regulations on risk assessment fixed in the "Declaration on Working Principles for Risk Analysis for Food Safety" issued by the Codex Alimentarius Commission gave grounds for convergence between risk assessment principles adopted in the RF and world practices in the field. These regulations are now fixed in some regulatory and methodical documents both adopted and being now considered ${ }^{5}$ etc.

${ }^{2}$ CU TR 021/2011. On food products safety: The Customs Union Technical Regulations [web-source] // KODEKS: an electronic fund of legal and reference documentation. - URL: http://docs.cntd.ru/document/902320560 (date of visit September 16, 2018). CU TR 023/2011. TR for juice products made of fruits and vegetables: The Customs Union Technical Regulations [websource] // KODEKS: an electronic fund of legal and reference documentation. - URL: http://docs.cntd.ru/document/902320562 (date of visit September 20,2018). TR 201_/00_/ CU. On grain safety. The Customs Union Technical Regulations [web-source] // KODEKS: an electronic fund of legal and reference documentation. - URL: http://docs.cntd.ru/document/1200083846 (date of visit September 20, 2018). CU TR 024/2011. Technical Regulations for fat and oil products (last edited on April 23, 2015) [web-source] // KODEKS: an electronic fund of legal and reference documentation. - URL: http://docs.cntd.ru/document/902320571 (date of visit September 20, 2018).

${ }^{3}$ On application of risk-oriented approach when organizing specific types of the state control (surveillance) activities and making alterations into some RF Governmental Regulations: The RF Governmental Order Issued on August 17, 2016 N 806 [websource] // KonsultantPlus. - URL: http://www.consultant.ru/document/cons_doc_LAW_203819/(date of visit September 20, 2018).

${ }^{4}$ On sanitary-epidemiologic welfare of the population: The RF Federal law No. 52-FL issued on March 30, $1999 \mathrm{~N}$ [websource] // KonsultantPlus. - URL: http://www.consultant.ru/document/cons_doc_LAW_22481 (date of visit September 20, 2018).

${ }^{5}$ MG 2.1.10.0067-12. Population health risk assessment under exposure to microbe factors contained in food products. Methodical grounds, principles and assessment criteria: Methodical Guidelines [web-source] // KODEKS: an electronic fund of legal and reference documentation. - URL: http://docs.cntd.ru/document/1200095230 (date of visit September 16, 2018). SER "Sanitary requirements to providing safety of the environment and products for population health" (a draft). 
According to Working Principles for Risk Analysis for Food Safety issued by the Codex Alimentarius Commission, risk analysis should:

- be systemic and consistent;

- be open and transparent;

- envisage some functional distinction between risk assessment and measures aimed at its prevention and minimization;

- include assessment and revision of the results when fresh scientific data are obtained.

Implementation of basic principles for risk analysis, for example, its systemacy and consistence, is fixed in regulatory documents which set forth Rospotrebnadzor functions and authority. According to the Provisions for the Federal Service, it has the following authority:

- as regards risk assessment: to organize and conduct necessary inspections and assessment, including those related to surveillance in the food products safety sphere;

- as regards risk management: to perform surveillance and control over conformity with the obligatory legislative requirements to food products;

- as regards risk communication: to inform state authorities and the population about all the measures taken to provide sanitaryepidemiologic welfare of the population including managing health risks caused by food products. Structural approach to risk analysis is implemented in full conformity with "The Provisions for the Federal Service for Surveillance over Consumer Rights protection and Human Well-being"6.

Functional distinction between risk assessment performed by expert organizations and implementation of measures aimed at risk prevention and minimization conducted by surveillance authorities also fully corresponds to risk analysis principles. Risk assessment is to be performed by 85 centers for hygiene and epidemiology and 29 scientific-research or- ganizations; risk management and risk communications are to be accomplished by 84 Rospotrebnadzor regional offices. Rospotrebnadzor scientific-research institutions are responsible for working out methodical and regulatory grounds for health risk assessment and management. These institutions develop up-to-date models and criteria for health risk assessment and classification, including risks related to food products.

Common concepts on permissible health risks levels are one of the most vital issues related to harmonization of assessment criteria for risks caused by consumer products; it is especially true for food products. Internationally accepted risks levels classification, from De Manifestis to De Minimus (Table 1) is applied in health risk assessment practices in Russia. Risk value equal to $1 \cdot 10^{-4}$ is considered to be a permissible risk level for consumers and the population in general.

Harmonization is taking place simultaneously with creation, development and implementation of tools for all the risk analysis components in the RF: risk assessment, risk management, and risk communications.

We can spot out development of theoretical grounds for analysis of health risks caused by food products as one of the basic aspects in the process [12]. The Russian Academy of Sciences and Rospotrebnadzor have accumulated certain experience related to development of fundamental grounds for assessing health risks caused by food products contamination [13-15].

The most interesting findings related to assessing health risks caused by food products contamination are:

- mathematical modeling of body functions;

- analysis of interpolation of impacts exerted by chemical and biological factors; markers.

- substantiation for a set of biological

${ }^{6}$ On Approval of Provisions about the Federal Service for Surveillance over Consumer Rights Protection and Human Wellbeing: The RF Governmental Order issued on June 30, 2004 No. 322 [web-source] // Garant. - URL: http://base.garant.ru/12136005/ (date of visit September 18, 2018). 
Risk levels classification ${ }^{7}$

\begin{tabular}{|l|c|}
\hline \multicolumn{1}{|c|}{ Risk level } & $\begin{array}{c}\text { Individual lifelong risk } \\
\text { of a grave disease or death }\end{array}$ \\
\hline $\begin{array}{l}\text { High (De Manifestis) risk; is not acceptable; it is necessary to imple- } \\
\text { ment activities aimed at its elimination or reduction }\end{array}$ & $>10^{-3}$ \\
\hline $\begin{array}{l}\text { Average risk; when population is exposed to it, it is necessary to per- } \\
\text { form dynamic control and profound examination of risk sources and } \\
\text { possible consequences of adverse impacts in order to make a decision } \\
\text { on risk management measures }\end{array}$ & $10^{-3}-10^{-4}$ \\
\hline $\begin{array}{l}\text { Low risk; is acceptable (this is generally a level hygienic standards } \\
\text { are set at) }\end{array}$ & $10^{-4}-10^{-6}$ \\
\hline $\begin{array}{l}\text { Minimal (De Minimus) risk; this is a desirable (target) risk level which } \\
\text { can be detected during prevention activities }\end{array}$ & $<10^{-6}$ \\
\hline
\end{tabular}

Health risk assessment is a hygienic and biologically oriented examination. Results of research on regularities in a pathological process and its modification under exposure to risk factors are a fundamental basis for it. Biokinetic modeling of body organs and systems is essential for health risk assessment. Creation of mathematical models for specific systems, and in future for the whole human body, can give grounds for simulation prediction of its responses to impacts exerted by risk factors related to food products. We can consider the following examples: simulation prediction of negative consequences for functional state of some gastrointestinal tract sections which can be caused by certain food products consumption $[16,17]$, as well as impacts exerted by chemical risk factors on the immune and neuroendocrine systems [18].

Probabilistic and deterministic modeling techniques are applied in world practice. In spite of being very promising, probabilistic models are quite rare these days. "Methodology for health risk assessment..." [19] recommended by the EAEU proposes to apply improved deterministic risk evolution models for risk assessment.

When we consider various aspects of mathematic modeling, we should pay closer attention to an issue related to interpolation of impacts exerted by chemical and biological factors of food products. For example, residual quantities of chemical anti-microbe prepa- rations can result both in creation of microflora which is resistant to them and in gut organisms imbalance [20-22]. Mathematical modeling of relationship between a relative gut organisms number and tetracycline concentration reveals prevailing inhibition of obligate microorganisms.

A principle regularity in replacement of obligate gut microorganisms with facultative ones is shown in Figures 1 and 2.

The process results in $4 \%$ higher risks of the digestive system diseases (the gastrointestinal tract diseases and food allergy) and 8\% higher risk of immune-dependent health disorders (blood diseases and immune disorders).

Elements included into the technique are being improved at each stage in risk assessment. Thus, at risk identification stage, in order to select most susceptible population groups, it is advisable to apply biological parameters which allow for individual peculiarities of a body. Candidate genes polymorphisms can be used as indicators of individual sensitivity to impacts exerted by adverse chemicals in food products (Figure 3). These indicators are quite specific in terms of a probable negative effect exerted by a specific contaminant.

A key task at risk identification stage, the first one in risk assessment, is a preliminary aggregation of all the available data on a sphere where a risk is detected, its indicators, and basic elements of a security system.

${ }^{7} \mathrm{G}$ 2.1.10.1920-04. Guidelines on assessment of population health risk under exposure to chemicals which pollute environment. - M.: Federal Center of State Sanitary and Epidemic Surveillance, RF Public Health Ministry, 2004. - 143 p. 


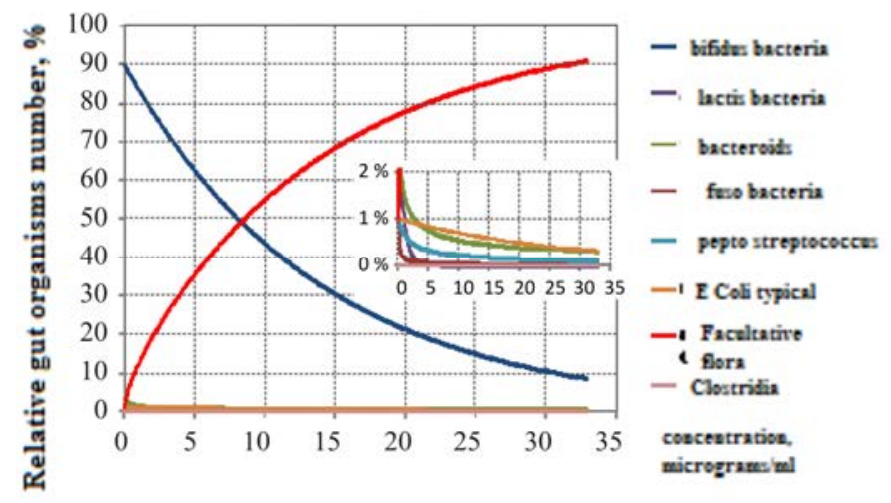

Figure 1. A relationship between relative gut organisms number (\%) and tetracycline concentration

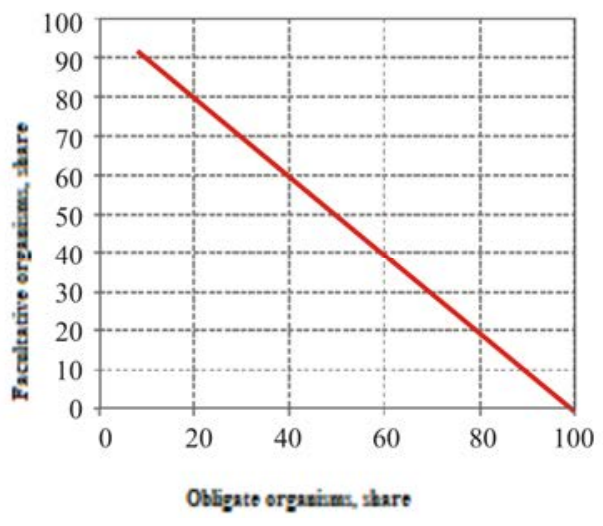

Figure 2. A ratio of obligate and facultative gut organisms

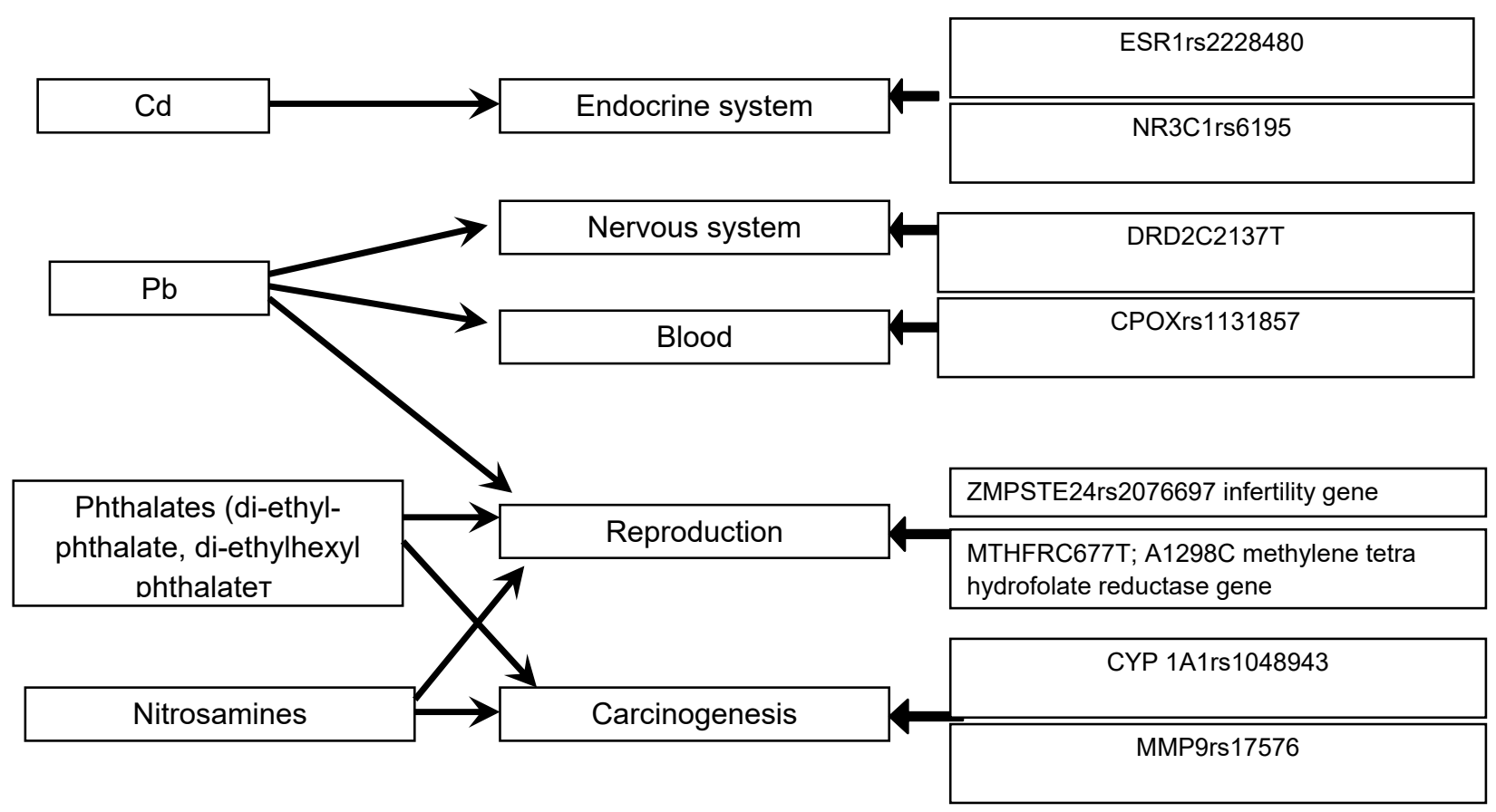

Figure 3. Indicators of individual sensitivity to impacts exerted by adverse chemicals in food products: candidate genes polymorphisms

Contemporary threats, for example, microorganisms being resistant to anti-microbe preparations, require development of corresponding forms for submission of necessary data (risk profiles). Thus, when we develop a risk profile for salmonellas which are resistant to anti-microbe preparations (AMP), we highlight such priority products and manufacturing processes in risk sphere description which can be dangerous as per a criterion of being contaminated with AMP-resistant salmonellas (eggs and poultry, poultry farming); we spot out possible ways of AMP occurrence (appli- cation of fluoroquinolones in feed and in birds treatment); we describe potential health risks for consumers (greater number of salmonellosis with average and/or severe gravity); we enlist possible activities aimed at reduction in resistant microorganisms number (control over application of fluoroquinolones in poultry production). We also propose risk indicators, the basic ones being a share of resistant microorganisms in food products (up to $60 \%$ of salmonellas detected in poultry meat are resistant to fluoroquinolones), a share of food products contaminated with resistant microorganisms 
(up to $22 \%$ of poultry meat is contaminated with resistant salmonellas). We identified the following basic elements in the security system: HACCP system and monitoring over microbe contamination and residual AMP quantities (control over disinfection of equipment at poultry farms and factories, monitoring over fluoroquinolones application in manufacturing processes) and measures aimed at reduction of food contamination with AMP-resistant microorganisms.

Exposure assessment stage requires chemical and analytical support. Apart from quite developed techniques for identification of hazardous factors in food products, exposure markers determination is also essential for health risk assessment validity. Exposure markers are concentrations of either contaminants themselves or their metabolites in biological media; here we can apply, for example, mass-spectrometry with inductively coupled plasma to detect metals, or high performance liquid chromatography to detect phthalates and di-methyl ether of terephthalic acid in blood or urine; capillary gas chromatography is applied to detect nitrosamines in blood, etc.

Together with exposure markers, a set of immunologic, biochemical, genetic and other markers of an effect is applied at the stage when "exposure - effect (response)" relationship is assessed. Thus, for example, parameters characterizing disorders in processes regulation associated with metabolites, proteome, immune and genetic state of a body, are applied as markers of an effect caused by some food contaminants (Table 2).

Markers of exposure and effect together with epidemiologic models create informational background for detecting regularities and calculating parameters for further health risk assessment. Detected regularities along with experience accumulated in simulation modeling of physiological processes gave grounds for multi-level modeling of health risk evolution. Such models allow to predict negative effects both for critical systems and organs and for a body as a whole.

Risk evolution model which describes disorders in human body functions has a number of advantages. They are a possibility to simulate risk accumulation; risk assessment for preset exposure scenarios; calculation of reduction in expected life span; classification of risk levels with risk acceptability assessment.

Table 2

Markers of effects produced by some food contaminants

\begin{tabular}{|l|l|l|}
\hline $\begin{array}{c}\text { Food } \\
\text { contaminant }\end{array}$ & \multicolumn{1}{|c|}{ Effect } & \multicolumn{1}{|c|}{$\begin{array}{c}\text { Markers } \\
\text { of effect }\end{array}$} \\
\hline Phthalates & $\begin{array}{l}\text { Endocrine and } \\
\text { reproductive } \\
\text { state disorders }\end{array}$ & $\begin{array}{l}\text { Increase in LDLP, } \\
\text { sex hormones im- } \\
\text { balance, leptin } \\
\text { deficiency }\end{array}$ \\
\hline $\mathrm{Cd}$ & $\begin{array}{l}\text { Endocrine } \\
\text { state disorders }\end{array}$ & $\begin{array}{l}\text { Testosterone con- } \\
\text { tents imbalance, } \\
\text { a/spermic antibod- } \\
\text { ies }\end{array}$ \\
\hline $\mathrm{Pb}$ & $\begin{array}{l}\text { Nervous state } \\
\text { disorders }\end{array}$ & $\begin{array}{l}\text { Decrease in sero- } \\
\text { tonin content }\end{array}$ \\
\cline { 2 - 3 } & $\begin{array}{l}\text { Hemopoiesis } \\
\text { disorders }\end{array}$ & $\begin{array}{l}\text { Increase in DALA } \\
\text { content in urine, } \\
\text { anemia }\end{array}$ \\
\cline { 2 - 3 } & $\begin{array}{l}\text { Reproductive } \\
\text { state disorders }\end{array}$ & $\begin{array}{l}\text { Sex hormones im- } \\
\text { balance, hyperpro- } \\
\text { duction of HAFP, } \\
\text { HHGT }\end{array}$ \\
\hline Nitrosamines & Carcinogenesis & $\begin{array}{l}\text { Hyperproduction } \\
\text { of oncomarkers } \\
\text { (HAFP, CA199, } \\
\text { CA724, CA242) }\end{array}$ \\
\hline
\end{tabular}

These possibilities were applied on the basis of harmonized procedures when experts (including the author of this paper) assessed health risk caused by ractopamine entering a body under various conditions and validated that its content in meat products was not acceptable. It was shown that, given an average level of animal products consumption by the RF population, permissible residual content of ractopamine recommended by Codex Alimentarius Commission is (scenario 1) substantially higher than in the case when ractopamine is introduced in quantities equal to the lower limit of its quantitative determination in tissues (3-5 $\mu \mathrm{g} / \mathrm{kg}$ ) (scenario 2). Figures 4 and 5 show the results of health risk evolution modeling under exposure to ractopamine. 
The suggested methodical approaches to risk evolution modeling taking into account experience of their application gave grounds for health risk assessment methodology. It is usually applied to assess risks caused by exposure to chemical, physical, and biological factors and to determine safety of products (goods) according to parameters recommended by the Eurasian Economic Commission. These methodical approaches allow not only to assess and classify multi-factor lifelong risks, but also to determine their structure as per factors and responses.

Risk characteristics with estimated index calculation underlie differentiation of risk management measures which can be as tough as total withdrawal of food products from markets provided that risk level is very high (Table 3).

Risk management related to risks caused by food products include such priority spheres as management procedures development (risky supplies, HACCP); optimization of surveillance and control activities; validation of hygienic requirements and standards as per acceptable risk criteria.

Regulatory documents that determine the system of managing health risks related to food products in the Russian Federation are for the most part harmonized with world practices, first of all, with European standards. HACCP basic principles and the necessity of their implementation are fixed in the EAEU legislation on technical regulation.

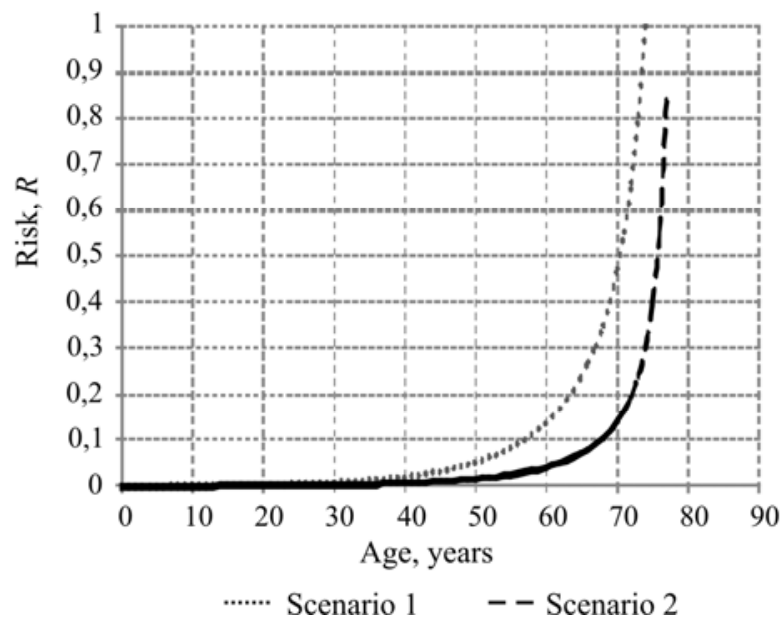

Figure 5. Reduced risk of functional disorders in the cardiovascular system

Figure 4. Additional risk of functional disorders in the cardiovascular system

Risk management measures chosen as per results of risk evolution assessment

\begin{tabular}{|c|c|l|}
\hline $\begin{array}{c}\text { Estimated } \\
\text { index of risk }\end{array}$ & $\begin{array}{c}\text { Products risks } \\
\text { characteristics }\end{array}$ & \multicolumn{1}{c|}{ Risk management measures } \\
\hline Lower than 0.05 & Negligible risk & $\begin{array}{l}\text { Any measures are applied only if there are complaints or recla- } \\
\text { mations }\end{array}$ \\
\hline $0.05-0.35$ & Moderate risk & $\begin{array}{l}\text { Risk communication (labeling) } \\
\text { Risk minimization at stages when a product is designed or } \\
\text { manufactured }\end{array}$ \\
\hline $0.35-0.6$ & High risk & $\begin{array}{l}\text { A product is included into risky supplied category } \\
\text { Risk communication } \\
\text { Limitations imposed on product output and application }\end{array}$ \\
\hline Higher than 0.6 & Vey high risk & $\begin{array}{l}\text { A product is included into risky supplied category } \\
\text { Urgent risk communication } \\
\text { A product is withdrawn from the market }\end{array}$ \\
\hline
\end{tabular}


Table 4

Estimation matrix for health risk level applied to assign a product into risky supplies

\begin{tabular}{|l|c|c|c|c|}
\hline \multicolumn{2}{|c|}{$\begin{array}{c}\text { Probability of } \\
\text { health disorders } \\
\text { caused by product } \\
\text { application }\end{array}$} & \multicolumn{3}{|c|}{ Health disorder gravity } \\
\cline { 3 - 5 } & Grave & Average & Mild \\
\hline $\begin{array}{l}\text { Very } \\
\text { high }\end{array}$ & $1 / 10$ & $\begin{array}{c}\text { Very } \\
\text { high }\end{array}$ & $\begin{array}{c}\text { Very } \\
\text { high }\end{array}$ & High \\
\hline High & $1 / 100$ & $\begin{array}{c}\text { Very } \\
\text { high }\end{array}$ & High & Moderate \\
\hline Average & $1 / 1000$ & High & Moderate & Low \\
\hline Low & $1 / 10000$ & Moderate & Low & Low \\
\hline
\end{tabular}

Risky supplied identification is one of tools for managing consumer health risks caused by food products. Experts in the Russian Federation worked out a procedure for assigning food products into intolerable risk group in accordance with the estimation matrix (Table 4).

Low quality products which can cause serious health risk (risk levels are "very high" and "high") should be assigned into risky supplies category. As per assessment results risky products can be registered in the Eurasian Economic Union Information system for technical regulation, sanitary and phytosanitary measures; it can also be registered in the Customs Union integrated information system for external and mutual trade (an information source for "supplies of products which cause intolerable risks").

In 2015 a risk-oriented model for surveillance and control activities performed by Rospotrebnadzor was fixed in the RF legislation on the basis of legislative documents and initiatives [10]. The model called for a new classification, both for food products and objects under surveillance which produced and distributed them. The classification was based on parameters of population risk occurring when fixed requirements were violated $\left(R^{\mathrm{I}}\right)$. Methodical approaches to assessment of these parameters allow not only for probable violations of obligatory requirements to food products and potential health risk but also for regional peculiarities of food products consumption.

$$
R^{I}=\sum_{i}\left(p_{i} \cdot u_{i}\right) \cdot W
$$

where:

$p_{i}$ is probability of obligatory requirements to food products safety being violated; requirements are taken as per $i$-th criterion (factor) during a single inspection. Chemicals, microbiological and parasitic agents, radiological parameters, and genetically modified organisms can be considered hazardous factors, and their contents in products are usually inspected during surveillance and control activities;

$u_{i}$ is relative health risk caused by violation of safety requirements to $i$-th factor in $j$-th product;

$W$ is a coefficient which characterizes regional peculiarities of food products consumption.

When population consume food products which don't correspond to safety requirements, it can cause health risks; basing on a level of such risks, food products can be assigned into one of six basic risk categories, from low to extremely high (Table 5).

Table 5

Estimation matrix for health risk level applied to assign products into risky supply categories

\begin{tabular}{|l|c|}
\hline \multicolumn{1}{|c|}{$\begin{array}{c}\text { Risky supplies } \\
\text { category }\end{array}$} & $\begin{array}{c}\text { Range of potential } \\
\text { health risk values }\left(R^{\mathrm{I}}\right)\end{array}$ \\
\hline Extremely high & $>1^{*} 10-1$ \\
\hline High & $10-2<R \leq 1^{*} 10-1$ \\
\hline Considerable & $10-3<R \leq 1^{*} 10-2$ \\
\hline Average & $10-4<R \leq 1^{*} 10-3$ \\
\hline Moderate & $10-6<R \leq 1^{*} 10-4$ \\
\hline Low & $<10-6$ \\
\hline
\end{tabular}

This classification was tested and it allowed to define that there are no food products in the RF which can be considered as causing extremely high risks. The most significant risks (which are high) are caused by bakery products and confectionary (this group comprises all the types of confectionary, including cream ones), watermelons, fish and fish products. Canned food, milk and dairy products, poultry, soft beverages, etc. are assigned into the considerable risk category. 
The risk-oriented model for surveillance over food products is aimed at protecting consumer rights; to fulfill this function, the suggested classification allows for such a component in any risk as property losses borne by a consumer in situations when legislation requirements were violated. When such type of risk is detected, experts take into account not only a probability of a consumer buying unsafe food products, but also his or her potential property losses caused by impossibility to consume them $\left(R^{\mathrm{II}}\right)$

$$
R^{I I}=p^{I I} \cdot u^{I I} \cdot V
$$

where:

$p^{\text {II }}$ is a probability that a consumer buys unsafe food products; it is estimated as per a share of products which were withdrawn due to control and surveillance activities;

$u^{\text {II }}$ shows potential property losses caused by impossibility to consume a single food product (ruble/kg, ruble/1, ruble/unit etc.);

$V$ is an annual volume of a food product consumption by one person $(\mathrm{kg} /$ year, $1 /$ year, units/year etc.).

A value equal to $70 \%$ of population earnings is considered to be a critical level of property losses risk because a share of population living wage in them amounts to about $30 \%$ in the RF.

A risk category a food product is assigned into determines scope of control required during scheduled inspections. Thus, if a product is considered to cause high or considerable risk, it is a subject to a full scope of laboratory and documentary control. Products from extremely risky category are subject to control as per maximum full list of factors.

Requirements to food products safety are to a significant extent violated due to sanitary legislation being breached at objects where food products are manufactured. Therefore, experts single out six categories of such objects as per potential health risk criteria. Methodical approaches to classification of objects which manufacture food products take into account health risks related to violation of sanitary legislation and borne by workers, population, and consumers. This classification underlies control and surveillance activities planning, first of all, inspections frequency. Thus, for example, it is advisable to hold annually inspections at objects which cause extremely high risk; objects which cause low risks can be released from any scheduled inspections.

The methodical approaches were tested and the tests revealed that potential health risks caused by even a single violation of sanitary legislation can vary significantly depending on a type of an economic entity which manufactures and distributes food products. Thus, for example, it was detected that when sanitary legislation was violated in orphanages where practically all the consumed food products were manufactured in-house, it could do much greater damage than the same situation occurring at industrial enterprises.

Scientific organizations of the Russian Academy of Science, Public Healthcare Ministry, and Rospotrebnadzor have accumulated certain experience in assessing chemical and microbiological risk factors related to food products. This experience was applied in development of hygienic standards as per risk criteria as a part of sanitary legislation. A number of such standards are already developed (maximum permissible levels of ractopamine and tetracycline-type antibiotics in meat products, nitrates in vegetables, and L. Monocytogenes in meat, fish and dairy products).

Risk communications are an essential part of risk analysis; they are exchange of information related to risk factors and levels between food products manufactures and consumers, state and local authorities, experts and civil society institutions.

Traditionally, risk communications in Russia are wrongly replaced with their simplified model, namely, informing about risks. Food products consumers are only passive objects in such a model, and they don't take any active part in discussing risk acceptability and measures taken to manage it. However, today it is advisable to develop a two-sided risk communications model which can provide involvement of all the interested parties into risk management decision-making. Development of a dialogue risk-communications model in 
the food products safety sphere is possible only after certain tasks are solved. They are:

- first of all, low information activity of consumers. Thus, according to data obtained by Russian organizations involved in public opinion studies, more than one third of consumers in Russia practically never pay any attention to labels on food products; as for male consumers, the figure is almost a half;

- secondly, Russians usually don't have any persistent positive attitudes towards savepreserving behavior. As questionnaires results reveal, Russians are well aware of risks related to fast food consumption, but more than one third of respondents buy such food on a regular basis;

- thirdly, it is necessary to improve the overall state system of risk communications, namely, to change information distribution channels and start to use those which are popular among target audiences;

- fourthly, experts are not involved into a substantive dialogue about risks to the extent they should be. Unfortunately, nowadays information on risk provided by experts as per risk assessment results is not adapted either for population or decision makers.

Overall, in spite of wide implementation of risk analysis methodology for assessing risks caused by food products, there are certain tasks which are to be solved in the Russian Federation in the nearest future. They are:

- more substantial inclusion of health risk assessment methodology into the RF sanitary legislation and creation of legislative base for assessment of health risks caused by food products contamination and property losses related to such risks and borne by consumers;

- more prompt development and implementation of harmonized risk-based quality standards as criteria of food products safety for health and their application in control and surveillance activities;

- development of information base for health risk assessment and estimation of property losses borne by consumers including activities performed within monitoring programs;

- wider international cooperation on issues related to analyzing risks of food products contamination including activities organized and held by international organizations.

Funding. The research was not granted any sponsor support.

Conflict of interests. The authors state there is no any conflict of interests.

\section{References}

1. Gordeev A.V., Maslennikova O.A., Vermel'D.F., Altukhov A.I., Bespakhotnyi G.V., Borisenko E.N., Daurskii A.N., Dolgushkin N.K., Zaverukha A.Kh., Nazarenko V.I., Runov B.A., Ul'yanov E.V., Ushachev I.G., Cheshinskii L.S., Dragaitsev V.I., Prokop'ev G.S., Sandu I.S., Silaeva L.P., Starostina I.L., Suglobov A.E. [et al.]. Bezopasnost' Rossii. Pravovye, sotsial'no-ekonomicheskie i nauchno-tekhnicheskie aspekty. Prodovol'stvennaya bezopasnost' [Safety of Russia. Legal, socioeconomic and scientific-technical aspects. Food safety]. Moscow, 2000, vol. 1, pert 1, 537 p. (in Russian).

2. Tutel'yan V.A., Nikityuk D.B., Khotimchenko S.A. Normative base for food quality and safety assessment. Russian Journal of Rehabilitation Medicine, 2017, no. 2, pp. 74-120 (in Russian).

3. Edelev D.A., Kantere V.M., Matison V.A. An estimation of risks - the major element of a risk management of food production. Pishchevaya promyshlennost', 2011, no. 9, pp. 14-16 (in Russian).

4. Matison V.A., Arutyunova N.I. The Risk - Based Approach to Ensure the Safety and Quality of Food. Pishchevaya promyshlennost', 2016, no. 5, pp. 16-20 (in Russian).

5. Altukhov A.I., Afanas'ev V.A., Baturin A.K., Butkovskii V.A., Glushchenko V.D., Zlochevskii A.L., Izmailov V.A., Il'ina O.A., Iunikhina V.S., Kislov S.V., Kraus S.V., Kustov V.N., Kovalev Yu.I., Mamikonyan M.L., Moshkovich V.N., Nechaev A.P., Nosenko S.M., Ovechkin A.B., Ponomarev A.N., Tutel'yan V.A. [et al.]. [Food independence of Russia in 2 volumes]. Moscow, Tekhnologiya TsT Publ., 2016, vol. 1, 560 p. (in Russian).

6. Nurgalieva M.T., Smagulov A.K., Iskakova Zh.A. the issues of quality and safety control of food products in the framework of EU and EEU. Nauka i Mir, 2016, vol. 1, no. 3 (31), pp. 86-91 (in Russian).

7. The Future of Risk Assessment in the European Union: The Second report on the Harmonisation of Risk Assessment Procedures / Scientific Steering Committee, EU. Brussels, 2003, 112 p. 
8. Nikitin S. About Russia's accession to the Agreement on the Application of Sanitary and Phytosanitary measures of the WTO. Mezhdunarodnyi sel'skokhozyaistvennyi zhurnal, 2009, no. 4, pp. 3-6 (in Russain).

9. Matison V.A., Yasinov O.Yu. Food Safety: Research and Training. Pishchevaya promyshlennost', 2017, no. 4, pp. 21-24 (in Russian).

10. Berketova L.V., Kryukova E.V. Analiz riskov pri obespechenii bezopasnosti produktov pitaniya [Risk analysis in providing food products safety]. Voprosy pitaniya, 2014, vol. 83, no. S3, pp. 153 (in Russian).

11. Makarov D.A., Komarov A.A., Selimov R.N. Obespechenie khimicheskoi bezopasnosti pishchevoi produktsii v Rossiiskoi Federatsii [Providing chemical safety of food products in the Russian Federation]. Kontrol' kachestva produktsii, 2017, no. 5, pp. 21-26 (in Russian).

12. Zaitseva N.V., Popova A.Yu., May I.V., Shur P.Z. Methods and technologies of health risk analysis in the system of state management under assurance of the sanitation and epidemiological welfare of population. Gigiena i sanitariya, 2015, vol. 94, no. 2, pp. 93-98 (in Russian).

13. Zaitseva N.V., Shur P.Z., May I.V., Kir'yanov D.A. Approaches to the assessment of integrated health risk population based on evolution of mathematical models. Zdorov'e naseleniya i sreda obitaniya, 2011, vol. 223, no. 10, pp. 6-9 (in Russian).

14. Zaitseva N.V., May I.V., Kir'yanov D.A., Sboev A.S., Andreeva E.E. Conceptual and methodological aspects of improving the effectiveness of control and supervisory activities based on hazard and risk assessment and estimation of harm to health of the population. Zdorov'e naseleniya $i$ sreda obitaniya, 2014, vol. 261, no. 12, pp. 4-7 (in Russian).

15. First report on the harmonisation of risk assessment procedures. Part 1: The Report of the Scientific Steering Committee's Working Group on Harmonisation of Risk Assessment Procedures in the Scientific Committees advising the European Commission in the area of human and environmental health 26-27 October 2000 (published on the internet 20.12.2000). Available at: https://mobil.bfr.bund.de/cm/343/first_report_on_the_harmonisation_of_risk_assessment_procedures.pdf (16.09.2018).

16. Trusov P.V., Zaitseva N.V., Kamaltdinov M.R. A multiphase flow in the antroduodenal portion of the gastrointestinal tract: a mathematical model. Computational and Mathematical Methods in Medicine, 2016, vol. 2016, Article ID 5164029, 18 p. DOI: 10.1155/2016/5164029

17. Orlova E.D., Kamaltdinov M.R. Modelirovanie pishchevaritel'nykh protsessov v dvenadtsatiperstnoi kishke [Modeling of digestive processes in the duodenum]. Matematicheskoe modelirovanie $v$ estestvennykh naukakh, 2017, vol. 1, pp. 246-250 (in Russian).

18. Zaitseva N.V., Kiryanov D.A., Lanin D.V., Chigvintsev V.M. A mathematical model of the immune and neuroendocrine systems mutual regulation under the technogenic chemical factors impact. Computational and Mathematical Methods in Medicine, 2014, vol. 2014, Article ID 492489, 12 p. DOI: $10.1155 / 2014 / 492489$

19. Metodologiya otsenki riskov zdorov'yu naseleniya pri vozdeistvii khimicheskikh, fizicheskikh i biologicheskikh faktorov dlya opredeleniya pokazatelei bezopasnosti produktsii (tovarov) / Evraziiskaya ekonomicheskaya komissiya [Methodology of population health risks analysis under exposure to chemical, physical and biological factors aimed at determining safety parameters of products (goods) / the Eurasian economic Commission]. Moscow, Yumanite Media, 2014, 115 p. (in Russian).

20. Residue evaluation of certain veterinary drugs. Meeting 2010-Evaluation of data on ractopamine residues in pig tissues / Joint FAO/WHO Expert Committee on Food Additives. Italy, Rome, 2010, 52 p.

21. Alemanno A., Capodieci G. Testing the Limits of Global Food Governance: The Case of Ractopamine. Eur. J. Risk Regul, 2012, vol. 3, pp. 12.

22. Scientific Opinion of the Panel on Additives and Products or Substances used in Animal Feed (FEEDAP) on a request from the European Commission on the safety evaluation of ractopamine. EFSA J., 2009, vol. 1041, pp. 1-52.

Zaitseva N.V. Analysis of population health risks in the Russian Federation caused by food products contamination. Health Risk Analysis, 2018, no. 4, pp. 13-23. DOI: 10.21668/health.risk/2018.4.02.eng

Received: 13.10 .2018

Accepted: 14.12 .2018

Published: 30.12.2018 


\section{LEGAL ASPECTS OF RISK ASSESSMENT}

UDC 366.54

DOI: $10.21668 /$ health.risk/2018.4.03.eng

\section{PROVISION OF FOOD SAFETY AND CONSUMER RIGHTS PROTECTION IN THE EURASIAN ECONOMIC UNION LAW}

\section{L.N. Osaulenko}

Eurasian Economic Commission, 2 Letnikovskaya Str., bld. 1/2, Moscow, 115114, Russian Federation

International economic integration is a process of interaction between states that involves trans-border and barrierfree movement of products and services; it means gradual economic drawing together within a common (unified) market for consumer goods and services based on national legislation being harmonized and unified or similar regulation in specific spheres being created.

As the Eurasian integration is going on, it is important to provide and protect interests of consumers that naturally arise when administrative barriers are eliminated and goods and services flow more freely between the EAEU member states.

Our research object was a legal and regulatory base existing in the Eurasian Economic Union that regulates issues related to providing food products quality and safety and consumer rights protection.

Our research goal was to reveal what mechanisms for international cooperation and harmonization of national legislative standards existed in the EAEU countries in the sphere under consideration and to determine possible ways for their improvement.

As a result, we gave an overall characteristics for legal regulation in the sphere of providing food products safety in the Eurasian Economic Union as well as mechanisms for providing food products safety, both existing and being developed at the moment, that are based on risk assessment.

The analysis we performed allowed us to conclude that a system for providing food products safety that is being created now in the EAEU is a complex one and is aimed at providing safety of people's lives and health, at preventing consumer rights violation, and at informing about food-related health risks.

Creation of a system for food products safety is under way in the EAEU now, and it means that there are some preconditions for development of a global action program for the EAEU countries which will be aimed at consumer rights protection and providing high quality of products and services.

Key words: consumer rights protection, products safety, food products safety, risk assessment, the Eurasian Economic Commission, the Eurasian Economic Union.

The Eurasian Economic Union Treaty (hereinafter called the Treaty) ${ }^{1}$ was signed on May 29, 2014; according to it, all the EAEU member states are to create a unified market and to provide free flow of goods, services, capitals, and labor within it. According to provisions of the Treaty all the member states are to pursue a harmonized policy in the sphere of consumer rights protection.

Products safety is a basic and undeniable consumer right. An issue related to achieving a level of safety relevant to legal requirements is considered vital all over the world [1-4], including the EAEU member states [5-7]. The EAEU member states and the Eurasian Economic Commission (hereinafter called the Commission) are to make coordinated and efficient decisions that are aimed at protecting interests of all the consumer market participants, but first of all, consumers.

The EAEU member states fixed the grounds for a coordinated policy in the sphere

(c) Osaulenko L.N., 2018

Lidiya N. Osaulenko - Candidate Of Jurisprudence, Head of Consumer Rights Protection Division at Department for Sanitary, Phytosanitary and Veterinary Measures (e-mail: osaulenko@eecommission.org; tel.: +7 (495) 669-24-00 (ext. 5180); ORCID: https://orcid.org/0000-0003-2763-9173).

${ }^{1}$ The Eurasian Economic Union Treaty (signed in Astana on May 29, 2014) [web-source] // The Eurasian Economic Commission official web-site. - URL: http://www.eurasiancommission.org/(date of visit June 08, 2018). 
of consumer rights protection and promised to guarantee this protection; thus, they chose the only right way to develop their economic relations based on full responsibility to their citizens who are consumers on the unified market.

These consumers are numerous as more than 182 million people are citizens of the EAEU member states, and efficiency of the Eurasian integration depends on their wellbeing. Providing higher living standards for the EAEU states citizens directly depends on providing better citizens' health, and their health, in its turn, is based on coordinated and relevant activities performed by the EAEU member states and aimed at preventing low quality food products from penetrating the unified EAEU marker as such products are hazardous for people's life and health.

Specific attention paid to providing food products safety is determined by risks caused by unregulated food products distribution; such risks lead to food intoxications and official figures related to this health problem are much lower than actual ones [8].

The EAEU member states protect their citizens' right to get safe and qualitative food products with mechanisms that are worked out by the Commission.

Decisions made within the EAEU in the sphere of food products safety are aimed at protecting citizens' health as well as at providing basic consumer rights $[9,10]$ (a product should be safe, a consumer has the right to get reliable information on a product, it is unacceptable to deceive a consumer giving him or her false information on a product quality and properties, a consumer should be aware about possible ways to protect him or herself).

The EAEU Technical Regulations are issued in order to fix minimal necessary safety requirements for consumer products as well as to prevent any actions that can mislead a consumer.

At the EAEU level, the EAEU member states pursue a coordinated policy in the sphere of consumer rights protection that is aimed, among other things, at providing consumers, public authorities, and consumer so- cial organizations with relevant and reliable information about products (works, services), manufacturers, sellers, and contractors.

The EAEU authorities have created and constantly enlarge a legal framework that fixes clear and transparent requirements to food products starting from sanitary-epidemiologic and hygienic safety requirements up to data that are included into food products marking and ensure consumers right to obtain full and reliable information about these products.

Hygienic requirements and safety standards for food products are developed on the basis of scientific research and assessment of risks that can lead to hazardous impacts on a human body; international and regional standards, guidelines and (or) recommendations.

Unified sanitary-epidemiologic and hygienic requirements to products according to the Commission regulations are included into the EAEU Technical Regulations and allow to protect people's lives and health, the environment, as well as consumers rights, together with other documents that fix requirements to processes of manufacturing, storage, transportation, sales, and utilization of products that are subject to technical regulations, requirements to their marking and to procedures of assessment (confirmation) whether food products and processes of their manufacturing, storage, transportation, sales, and utilization, conform to standards.

Technical regulation for food products has its peculiarities; thus, it is extremely vital not only to provide their safety but also to fix certain requirements that bind a manufacturer to inform buyers about consumer properties of this or that product, such as a date when it was manufactured, shelf life, and food product structure. In other words, a manufacturer should provide a buyer with specific data that are to be shown on a label put on a packed food product [1, 1-12]. This approach is aimed at providing a buyer with reliable data on a food product structure and its consumer properties.

The EAEU Technical Regulations in the sphere of food products safety are created on 
the basis of their step-by-step harmonization with the international standards fixed by the Codex Alimentarius Commission, the EU regulations and directives, in particular the EU Regulations No. $178 / 2002^{2}$, No. $1169 / 2011^{3}$, The EU Orders No. 852/2004 ${ }^{4}, 853 / 2004^{5}$, $854 / 2004^{6}$ and taking into account economic development of the EAEU member states in the relevant sphere of food products manufacturing.

If manufactured products are of high quality, it helps to increase their competitiveness. Therefore, food manufacturers realized it was economically necessary to have some objective evidence that they truly manufactured qualitative and safe food $[9,10,13,14]$. To achieve the above mentioned goals, internationally accepted quality managements systems were created; they are, for example, a quality management system based on ISO 9001:2001 "Quality management systems Requirements". There are also food safety management systems based on the requirements fixed in the internationals ISO 22000:2005 standard "Food safety management systems - Requirements for any organization in the food chain".

Basics for creating conditions and procedures that provide conformity with minimal obligatory requirements in food manufacturing that are common for all the EAEU member states are fixed in the "common" Technical Regulations "On food products safety" (CU TR) ${ }^{7}$. These regulations specify that HACCP safety system (Hazard Analysis and Critical Control Point) should be applied as a system that provides food products safety.

When a manufacturer produces food products, all the production processes are to provide conformity of manufactured products with safety requirements. So, a manufacturer should develop, implement and maintain procedures based on HACCP principles.

The above mentioned system has one basic principle, notably, analysis of hazards via assessing significance of risks and hazards occurring at any stage in a product life cycle,

HACCP principles application allows a manufacturer to analyze all the stages in food production and to prevent all possible hazards and risks at this or that production enterprise [15-17].

In order to meet requirements fixed in technical regulations, manufacturers voluntarily apply international standards, and in case there are no such standards, national ones. As there are multiple food products manufactured at present, standards create reliable grounds for unambiguous food prod-

\footnotetext{
${ }^{2}$ Regulation (EC) No. 178/2002 of the European Parliament and of the Council of 28 January 2002 laying down the general principles and requirements of food law, establishing the European Food Safety Authority and laying down procedures in matters of food safety: [web-source]. - URL: https://www.fsvps.ru/fsvps-docs/ru/usefulinf/files/es178-2002.pdf (date of visit June 08, 2018).

${ }^{3}$ Regulation (EU) No 1169/2011 of the European Parliament and of the Council of 25 October 2011 on the provision of food information to consumers, amending Regulations (EC) No 1924/2006 and (EC) No 1925/2006 of the European Parliament and of the Council, and repealing Commission Directive 87/250/EEC, Council Directive 90/496/EEC, Commission Directive 1999/10/EC, Directive 2000/13/EC of the European Parliament and of the Council, Commission Directives 2002/67/EC and 2008/5/EC and Commission Regulation (EC) No 608/2004 (approved in Strasburg)(with amendments and supplements made on November 22, 2013) [web-source] // Гарант. - URL:http://base.garant.ru/70256896/ee127b952f55309e742991381e8bb5fe/ (date of visit June 08, 2018).

${ }^{4}$ Regulation (EC) No 852/2004 of the European Parliament and of the Council of 29 April 2004 on the hygiene of foodstuffs [web-source]. - URL: https://www.fsvps.ru/fsvps-docs/ru/usefulinf/files/es852-2004.pdf (date of visit June 08, 2018).

${ }^{5}$ Regulation (EC) No 853/2004 of the European Parliament and of the Council of 29 April 2004 laying down specific hygiene rules for food of animal origin [web-source]. - URL:https://www.fsvps.ru/fsvps-docs/ru/usefulinf/files/es853-2004.pdf (date of visit June 08, 2018).

${ }^{6}$ Regulation (EC) no 854/2004 of the European Parliament and of the Council of 29 April 2004 laying down specific rules for the organization of official controls on products of animal origin intended for human consumption [web-source]. URL:https://www.fsvps.ru/fsvps-docs/ru/usefulinf/files/es854-2004.pdf (date of visit June 08, 2018).

${ }^{7}$ The Decision by the Customs Union Commission made on December 09, 2011 No. 880 (edited on June 10, 2014) «On Approval of the Customs Union Technical Regulations "On food products safety" (together with CU TR 021/2011. The Customs Union technical Regulation "On food products safety") [web-source] // The Eurasian Economic Commission official web-site. URL:http://www.tsouz.ru/KTS/KTS33/Pages/R_880.aspx (date oif visit June 08, 2018).
} 
ucts identification and correct application of requirements fixed in technical regulations both by manufacturers and controlling authorities.

Decisions that are made within the EAEU and related to providing food products safety are based on risk assessment which, in its turn, is performed taking into account the unified Methodology for assessing population health risks under exposure to chemical, physical, and biological factors for determining parameters of products (goods) safety. The Methodology was developed by the Commission together with scientific organizations from Russia, Belorussia, and Kazakhstan.

Risk assessment is obligatory for creating competitive supply on food markets as it allows to provide food products safety and quality. And here consumer satisfaction is the most significant factor that influences efficiency of business processes management [18-20].

In a situation, when food products safety and quality are a manufacturer's responsibility, it is truly important to make businesses genuinely responsible; such businesses should base all their activities on prevention and minimization of risks related to each process in food chain.

We can't fail to take into account application of principles common for all the EAEU member states that are based on risk-oriented approach to state control as these principles are significant and efficient for business development [21].

In this relation, a draft Agreement on principles and approaches of state control has been created in the EAEU. This Agreement includes the following provisions:

- risk-oriented approach is to be implemented in all the EAEU member states. This approach means that state control (surveillance) is to be performed on the basis of assessing risks caused by violation of requirements fixed in the EAEU technical regulations. Assessment results substantiate a choice on intensity (duration, periodicity) of control (surveillance) activities. Forms and techniques of control activities depend on a risk level or a hazard category that are specific for this or that economic activity performed by an economic entity and (or) production objects at which this economic activity is performed. When making a choice on control activities and their forms and techniques, experts should take into account possible negative consequences caused by a situation when this economic entity violates obligatory requirements;

- prevention is to be a top priority rather than punishment for violation; thus, a priority is to create civilized and socially responsible businesses in the EAEU member states;

- a unified integrated information system is to be created in the EAEU; the system should contain data on hazardous products.

If the system is created, it will allow to achieve two goals. First, the system should provide prompt interaction between state control (surveillance) authorities aimed at organization of state control (surveillance) activities and prevention of manufacturing and distribution of products not conforming to obligatory requirements fixed in the EAEU technical regulations on the territory of the EAEU member states. This interaction should also involve systematic information exchange and exchange of experience in performing state control (surveillance) activities and organization of joint inspections. Second, the system should become an information source for consumers allowing them to obtain reliable and comprehensive information about products that are distributed on the EAEU market as well as about manufacturers, sellers, and importers.

So, the analysis we performed allows to conclude that the system for legal regulation of issues related to providing food products safety within the EAEU involves the following:

- the EAEU technical regulations are to fix obligatory requirements to food products safety (hygienic standards for food products safety developed on the basis of scientific research including risks assessment related to hazardous impacts on a human body); 
- a food manufacturer is to bear full responsibility for analysis of hazards that is to be performed via assessing risks significance and hazard levels at each stage in a product life cycle;

- the EAEU member states are to create unified techniques and criteria for health risk assessment that are to be applied for making decisions aimed at providing food products safety within the EAEU;

- the EAEU member states are to determine common approaches to state surveillance based on risks assessment; these approaches will allow to take all the necessary measures fixed in the national legislations of the EAEU member states and aimed at limiting or prohibiting manufacturing and distribution of products not conforming to requirements fixed in the EAEU technical regulations as well as at withdrawal of such products from the unified EAEU market in case of necessity.

Food products safety system that is being created with the EAEU under coordination by the Commission is to protect citizens' health; to protect consumers from being deceived; to provide proper informing of the society about detected products that don't conform to obligatory requirements.

This approach when adopted in legal regulation is a key precondition for providing food security which, in its turn, is among top priorities fixed in the EAEU coordinated policy in the sphere of consumer rights protection pursued jointly by the EAEU member states and the Commission.

This paper outlines a good example of a food products safety system being created within the EAEU; the experience can be applied for creating a system for providing safety and quality of all the consumer products and services that appear on the unified EAEU market. And here we should take into account all the spheres related to consumer legal rela- tions, and the EAEU member states and the Commission are to create unified "rules of the game" that will allow businesses to develop in such a way so that consumers could also truly benefit from the Eurasian integration.

As world practices show, provision of only safety of products (which is fully envisaged by legal documents within the EAEU legal system) doesn't allow to completely fulfill consumers' right to buy high quality goods or services.

It is quite promising for the EAEU member states to enhance cooperation in the sphere on issues related to further improvement of mechanisms for protecting consumer rights and interests. This cooperation is to be based on the EAEU strategy aimed at protecting consumer rights and interests via increasing quality and competitiveness of goods (services) produced in the EAEU member states and growing exports from these states.

The strategy when it is adopted will allow to combine efforts by the EAEU member states, to develop Eurasian standards for quality of goods or services, to provide a possibility to support activities by social organizations aimed at protecting consumer interests, and to create conditions for making businesses more socially responsible.

This work performed at the EAEU level will efficiently supplement activities performed by the EAEU member states and aimed at preventing hazardous and low quality goods and services from penetrating the unified EAEU market as well as at protecting consumers' health, safety, economic and legal interests.

Funding. The research was not granted any sponsor support.

Conflict of interests. The authors state there is no any conflict of interests. 


\section{References}

1. Attrey D.P. Regulatory requirements for labeling, health, and nutritional claim (Book Chapter). In book: Food Safety in the 21st Century: Public Health Perspective. Academic Press, 2016, pp. 497-506.

2. McEvoy J.D.G. Emerging food safety issues: An EU perspective. Drug Testing and Analysis, 2016, vol. 8, no. 5-6, pp. 511-520. DOI: 10.1002/dta.2015

3. Solaiman S.M., Ali A.N. The Most Serious Offenses and Penalties Concerning Unsafe Foods under the Food Safety Laws in Bangladesh, India, and Australia: A Critical Analysis. Food and drug law journal, 2015, vol. 70, no. 3, pp. 409-433.

4. Kees J., Burton S., Andrews J.C. Government efforts to aid consumer well-being: Understanding federal health warnings and disclosures (Book Chapter). In book: The Cambridge Handbook of Consumer Psychology, 2015, pp. 530-563. DOI: 10.1017/CBO9781107706552.020

5. Kokina V.V. Notifikatsiya organov po sertifikatsii kak instrument obespecheniya bezopasnosti tovarov v Evraziiskom Ekonomicheskom Soyuze [Notification of certification bodies as a tool to ensure the safety of goods in the Eurasian Economic Union]. NovaUm.Ru, 2018, no. 12, pp. 110-112 (in Russian).

6. Andreeva L.V. Technical regulations and standards as tools to ensure the safety and quality of goods, works and services in the Eurasian economic Union. Mezhdunarodnoe sotrudnichestvo evraziiskikh gosudarstv: politika, ekonomika, pravo, 2017, vol. 4, no. 13, pp. 67-78 (in Russian).

7. Arnautov O.V. On improvement of the mechanism for establishing and changing indicators of quality and food safety in the regulatory and legal acts of the Eurasian Economical Union. Voprosy pitaniya, 2016, vol. 85, no. 1, pp. 110-116 (in Russian).

8. Belova L.V., Pil'kova T.Yu., Eliovich I.G. K voprosu okhrany zdorov'ya naseleniya i zashchity prav potrebitelei alkogol'noi produktsii [On the issue of public health and the protection of the rights of consumers of alcoholic beverages]. Voprosy pitaniya, 2014, vol. 83, no. S3, pp. 12-13 (in Russian).

9. Versan V.G. Protection of consumer rights in the single consumer market of the eurasian economic union /EAЭC/. Problems. Ways of solution. Analitika razvitiya, bezopasnosti i sotrudnichestva: Bol'shaya Evraziya - 2030: Sbornik materialov IV Mezhdunarodnoi konferentsii 29 noyabrya 2017 g. [Analysis of development, security and cooperation: Greater Eurasia - 2030: Collection of materials of the IV International Conference November 29, 2017]. Moscow, 2017, pp. 40-43 (in Russian).

10. Gorina E.A. Kachestvo i bezopasnost' kak klyuchevye trebovaniya potrebitelei k pishchevoi produktsii [Quality and safety as key consumer requirements for food products]. Nauchnotekhnicheskie vedomosti SPbGPU. Ekonomicheskie nauki, 2009, no. 5, pp. 243-247 (in Russian).

11. Bochin L.A. Markirovka produktsii kak instrument obespecheniya bezopasnosti [Product labeling as a safety tool]. Vestnik rossiiskogo khimiko-tekhnologicheskogo universiteta imeni D.I. Mendeleeva: Gumanitarnye i sotsial'no-ekonomicheskie issledovaniya, 2015, vol. 2, no. 6, pp. 119-135 (in Russian).

12. Bitzios M., Jack L., Krzyzaniak S.-A., Xu M. Country-of-origin labelling, food traceability drivers and food fraud: Lessons from consumers' preferences and perceptions. European Journal of Risk Regulation, 2017, vol. 8, no. 3, pp. 541-558.

13. Kosenko G.N. Vnedrenie sistem menedzhmenta bezopasnosti pishchevoi produktsii: retsepty ot auditora i konsul'tanta [Introduction of food safety management systems: recipes from an auditor and consultant]. Sertifikatsiya, 2008, no. 4, pp. 14-16 (in Russian).

14. Karapetyan A.R. Napravleniya formirovaniya organizatsionnoi kul'tury $\mathrm{v}$ torgovom predprinimatel'stve [Directions for the formation of organizational culture in commercial business]. Nauchno-tekhnicheskie vedomosti SPbGPU. Ekonomicheskie nauki, 2009, no. 5, pp. 247-251 (in Russian).

15. Bortoletto A.M., Silvello G.C., Alcarde A.R Good manufacturing practices, hazard analysis and critical control point plan proposal for distilleries of cachaça. Scientia Agricola, 2018, vol. 75, no. 5, pp. 432-443. 
16. Chipurina L.G., Grishina I.V., Boitsov A.A. Opyt vnedreniya sistemy KhAASP na rybopererabatyvayushchem predpriyatii [Experience of implementing the HAASP system at a fish processing plant]. Rybprom: tekhnologii i oborudovanie dlya pererabotki vodnykh bioresursov, 2007, no. 2, pp. 38 (in Russian).

17. Leonov O.A., Shkaruba N.Zh. The elements of the haccp system in the production boiled-smoked sausages. Pishchevaya promyshlennost': nauka i tekhnologii, 2018, vol. 40, no. 2, pp. 44-52 (in Russian).

18. Kurepina M.V. Rights to the quality and safety of the goods, works and services: legal categories, their place in the system of the subjective rights of the consumer. Ekonomika. Predprinimatel'stvo. Okruzhayushchaya sreda, 2012, vol. 3, no. 51, pp. 61-65 (in Russian).

19. Romanenko N.G., Skvortsova T.A., Ismatulaev R.A. Nekotorye voprosy pravovoi reglamentatsii osnovnykh prav potrebitelya $\mathrm{v}$ Rossii [Some issues of legal regulation of basic consumer rights in Russia]. Nauka $i$ obrazovanie: khozyaistvo i ekonomika; predprinimatel'stvo; pravo $i$ upravlenie, 2017, vol. 83, no. 4, pp. 86-88 (in Russian).

20. Khurshudyan S.A. Consumer and Food Quality. Pishchevaya promyshlennost', 2014, no. 5, pp. 16-18 (in Russian).

21. Zaitseva N.V., May I.V., Sychik S.I., Fedorenko E.V., Shevchuk L.M. Analysis of legal and methodological grounds for risk-oriented surveillance over consumer products: tasks and development prospects in the Eurasian Economic Union. Health Risk Analysis, 2017, no. 4, pp. 4-22. DOI: 10.21668/health.risk/2017.4.01.eng (in Russian).

Osaulenko L.N. Provision of food safety and consumer rights protection in the Eurasian Economic Union law. Health Risk Analysis, 2018, no. 4, pp. 24-30. DOI: 10.21668/health.risk/2018.4.03.eng

Полечена: 26.10 .2018

Accepted: 15.11 .2018

Published: 30.12.2018 


\section{SCIENTIFIC AND METHODICAL APPROACHES TO RISK ANALYSIS IN HYGIENE AND EPIDEMIOLOGY}

UDC $613.2 ;-613.3$

DOI: $10.21668 /$ health.risk/2018.4.04.eng

\section{FOOD RISKS ANALYSIS AND WATER SAFETY}

\section{Yu.A. Rakhmanin, R.I. Mikhailova}

A.N. Sysin Research Institute of Human Ecology and Environmental Health, 10, build. 1, Pogodinskaya Str., Moscow, 119992, Russian Federation

Water in its native form or as a component of various food products is the greatest and most frequently consumed part of daily nutrition. Scientifically justified criteria of its quality include epidemiologic and radiation safety, chemical harmlessness, and favorable organoleptic (aesthetic) properties. Over recent years in Russia more than $91.5 \%$ population, and more than $96 \%$ in cities, have access to drinking water that conforms to all safety requirements. However, about 4-5\% of water samples taken from centralized water supply systems are not safe as per epidemiologic criteria. A drastic growth in chemical contamination of surface drinking water sources is another great concern.

The authors focus on a modified procedure for detecting dextrose-positive bacteria that is, apart from being greatly informative, makes performance of sanitary-epidemiologic analysis much faster (approximately 1 day faster). It is confirmed that microbiologic control over blue pus bacilli occurrence is vital. The authors also show that when an internationally accepted term "mineral water" is divided into "mineral drinking curative water" and "mineral drinking curative and table water" accepted in Russia, it requires adjustment of some legal and regulatory documents and strict definition of parameters that are subject to control. It is recommended to develop regulatory and legal base so that it could promote manufacturing of bottled high quality water, including that for children nutrition.

Overall, the authors show that development of drinking water market as a part of food market in the country requires updating of regulatory and methodical base for control over water quality and safety; improved systems of monitoring over epidemiologic safety based on up-to-date examination procedures and tools; putting health risk assessment methodology into practice in relation to consumption of water with diverse qualitative and quantitative structure.

Key words: drinking water, microbiological control, epidemiologic safety, legal and regulatory base.

Water, either in its native form or as a component in a structure of various food products, is the greatest and most frequently consumed part of our daily ration. Scientifically substantiated criteria of its quality include epidemic and radiation safety, absence of chemical hazards, and favorable organoleptic (aesthetic) properties [1-3]. Water is the only natural cleaning fluid on the earth and it is constantly exposed to primarily chemical and biological contamination; this contamination becomes more and more intense thus exceeding any technological possibilities for necessary water purification and its natural abil- ity for self-purifying. Given all that, water supplying organizations more and more frequently find themselves unable to provide population with good quality drinking water. Moreover, our knowledge is constantly enriched with data on new necessary parameters and standards related to quality of water consumed by people and these new data should also be taken into account.

In 2017133.956 million people living in the RF (91.5\% population) were provided with drinking water conforming to all the safety standards ${ }^{1} .96 .0 \%$ people living in urban settlements were provided with drinking water

(C) Rakhmanin Yu.A., Mikhailova R.I., 2018

Yurii A. Rakhmanin - Academician, Member of the Russian Academy of Sciences, Doctor of Medical Sciences, Professor, Chief Scientific Advisor (e-mail: 71info@sysin.ru; tel.: +7 (495) 540-61-71; ORCID: http://orcid.org/0000-0003-2067-8014).

Rufina I. Mikhailova - Doctor of Medical Sciences, Professor, Head of the Laboratory for Drinking Water Supply Hygiene and Biophysics of Water (e-mail: awme@mail.ru; tel.: +7 (499) 246-76-74; ORCID:http://orcid.org/0000-0001-7194-9131).

${ }^{1}$ On sanitary-epidemiologic welfare of the population in the RF in 2017: The State Report. - M.: The Federal Service for Surveillance over Consumer Rights Protection and Human Well-being, 2018. - 274 p. 
conforming to safety standards in 2017; as for people living in rural areas, $78.3 \%$ out of them were provided with such water.

In spite of all the achieved success, we have to ascertain that in Russia on average $4-5 \%$ samples of water taken from centralized water supply systems don't conform to epidemic safety requirements; it is especially true for the Far East region (more than 6-7\% samples). There were high risks that hazardous infectious diseases (cholera, poliomyelitis, typhoid fever, dysentery, infectious hepatitis and others) and parasitic diseases (lambliosis, cryptosporidiosis and other helminthiasis) could spread with water and it substantiated large-scale implementation of various chemical and physical technologies for water purification and disinfection as well as creation of the fastest and the most reliable techniques for indentifying relevant bacterial, virus, and parasitic agents in water.

Experts are also preoccupied with a drastic growth in chemical contamination of surface water objects. There are more than 170 million registered chemicals in the world (Chemical Abstracts Service, Register, USA), and more than 150 thousand of them enter the environment. Annually more than 1,000 new chemical compounds appear in our life, but only $15 \%$ of them are examined by toxicologists. As per the WHO data, in 2011 exposure to specific chemicals that occurred in the environment and at workplaces caused 4.9 million death cases all over the world $(8.3 \%$ from the total deaths) and 86 million years of life lost due to mortality and disability. There are some forecasts that chemicals market will be growing by $3 \%$ annually up to 2050 .

To disinfect water, chemicals reagents, primarily such strong oxidizers as chlorine and ozone, were applied, and experts revealed their adverse ability to create certain chemical compounds. These compounds were hazardous as they could cause remote mutagenic and carcinogenic effects on human health. For example, it was detected that when aniline-containing water was disinfected with chlorine reagents, $12 \%$ compounds that appeared in the process were mutagenic or carcinogenic, and up to $11 \%$ compounds that appeared when toluene-containing water was disinfected with ozone had similar properties.
As we have already pointed out, water is the only natural cleaning fluid on the planet; so, it becomes the most massive concentrator of various pollutants as well as a medium where these pollutants undergo chemical and biological transformation [4-6]. Experts all over the world are well aware of health risks that occur when contaminated drinking water is consumed [7-11]

Given all the above mentioned, it is not surprising that hundreds and even thousands of variable chemicals have started to appear in water, especially in surface water objects. In spite of approved hygienic standards fixing maximum permissible concentrations for more than 2,000 chemicals, there are no fixed permissible concentrations for the greatest share of detected compounds [5]. Thus, for example, when water taken from Izhevsk pond and drinking water supplied to people living in Izhevsk was analyzed with chromatographymass-spectrometry, the analysis results revealed that there were 232 volatile hydrocarbons in original water and there were no hygienic standards for 222 out of them; as for purified water, 103 compounds occurred in it including 94 not regulated by any safety standards (Table 1).

We examined the results of monitoring over quality of drinking water taken from centralized water supply systems in the RF Central Federal District collected in 2006-2011; the results revealed that water didn't conform (temporarily or permanently) to hygienic standards in all 18 regions of the District as per 18 parameters, including the most frequent nonconformity related to concentrations of $\mathrm{Fe}$, Mn, ammonium, nitrite, and nitrate N, B, sulfates, and chlorides in water (Table 2).

On average, 6 parameters that were higher than MPC were detected in the northern regions in the District (but apart from the parameters shown in Table 2, hygienic standards were additionally violated in Moscow as per chloroform; in Moscow region, as per petroleum products, thrichloromethane, tetrachloroand trichloroethylene). 5-6 parameters didn't conform to hygienic standards in the western regions; 7-8 parameters on average, in the 
southern regions. Mo concentrations were also higher than MPC in Tambov region. As for the eastern regions in the District, 11-12 parameters of drinking water didn't conform to hygienic standards there. Increased $\mathrm{Cr}$ concentrations (apart from the admixtures shown in table 2) were registered in Vladimir region; increased concentrations of $\mathrm{As}, \mathrm{Cu}, \mathrm{Zn}$, hexachlorocyclohexane, and 2, 4 dichlorophenoxyacetic acid were detected in Yaroslavl region.

Table 1

Results of chromatography-mass-spectrometry analysis of water taken from Izhevsk pond and water supplied to people living in Izhevsk [2]

\begin{tabular}{|l|c|c|c|c|}
\hline \multirow{2}{*}{ Chemicals category } & \multicolumn{2}{|c|}{ Izhevsk pond } & \multicolumn{2}{c|}{ Drinking water } \\
\cline { 2 - 5 } & Overall number & Regulated & Overall number & Regulated \\
\hline Alkanes & 44 & 0 & 22 & 0 \\
\hline Alkylbenzene & 29 & 2 & 12 & 2 \\
\hline Cycloalkanes & 19 & 0 & 12 & 0 \\
\hline PAH & 17 & 1 & 5 & 1 \\
\hline Phthalates & 9 & 2 & 8 & 3 \\
\hline Acids and their ethers & 33 & 1 & 11 & 0 \\
\hline Spirits, simple ethers & 21 & 0 & 1 & 0 \\
\hline Ketones & 13 & 1 & 3 & 1 \\
\hline Aldehydes & 4 & 1 & 1 & 1 \\
\hline Halogen-containing substances & 6 & 1 & 6 & 0 \\
\hline Sulfur-containing substances & 9 & 0 & 9 & 0 \\
\hline Other compounds & 28 & 1 & 19 & 1 \\
\hline TOTAL & 232 & 10 & 103 & 9 \\
\hline
\end{tabular}

Table 2

Results of monitoring over quality of drinking water taken from centralized water supply systems in the RF Central Federal District (2006-2011)

\begin{tabular}{|c|c|c|c|c|c|c|c|c|c|c|c|c|c|c|c|c|c|c|c|c|c|c|c|}
\hline \multirow{3}{*}{ No. } & & \multirow{3}{*}{ Regions } & \multicolumn{3}{|c|}{ Number of samples } & \multicolumn{18}{|c|}{ Parameters exceeding MPC } \\
\hline & & & \multirow[t]{2}{*}{ Tota } & \multicolumn{2}{|c|}{$\begin{array}{c}\text { Higher } \\
\text { than MPC }\end{array}$} & \multirow[t]{2}{*}{ 包 } & \multirow[t]{2}{*}{$\sum$} & \multirow[t]{2}{*}{$\stackrel{n}{\text { Z }}$} & \multirow{2}{*}{ 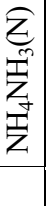 } & \multirow[t]{2}{*}{ I } & \multirow[t]{2}{*}{ 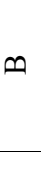 } & \multirow[t]{2}{*}{$\stackrel{\Upsilon}{Z}$} & \multirow[t]{2}{*}{$O_{\infty}^{+}$} & \multirow[t]{2}{*}{$\Xi$} & \multirow[t]{2}{*}{$\sum^{\infty}$} & \multirow[t]{2}{*}{ 己 } & \multirow[t]{2}{*}{$\vec{\mho}^{N}$} & \multirow[t]{2}{*}{$\dot{\omega}$} & \multirow[t]{2}{*}{2} & \multirow[t]{2}{*}{ 完 } & \multirow[t]{2}{*}{$\tilde{N}^{\infty}$} & \multirow[t]{2}{*}{$\varrho^{+}$} & \multirow[t]{2}{*}{ ت } \\
\hline & & & & no & $\%$ & & & & & & & & & & & & & & & & & & \\
\hline 1 & & Moscow $^{1)}$ & 20 & 2 & 10 & + & & & & & & & & & & & & & & & & & \\
\hline 2 & & Moscow region $^{2)}$ & 42 & 19 & 45 & + & + & + & + & + & + & + & & + & & & & + & + & & + & & + \\
\hline 3 & \multirow{2}{*}{ 동 } & Smolensk & 33 & 7 & 21 & + & + & + & + & & & & + & & + & & & + & & & & & \\
\hline 4 & & Tver' & 31 & 5 & 16 & + & + & & + & + & & & & & & & + & & & & & & \\
\hline 5 & \multirow{5}{*}{$\begin{array}{l}\vec{W} \\
\$ \\
3\end{array}$} & Tula & 31 & 8 & 26 & + & + & + & + & & & & + & & & + & & + & + & & & & \\
\hline 6 & & Orel & 28 & 6 & 21 & + & + & + & + & & + & & + & & & & & & & & & & \\
\hline 7 & & Bryansk & 27 & 4 & 15 & + & & + & & + & & & & & & & & & & & + & & \\
\hline 8 & & Kaluga & 20 & 8 & 40 & + & + & + & + & + & + & & & & & & + & & & & & & + \\
\hline 9 & & Kursk & 16 & 2 & 13 & + & + & & & & & & & & & & & & & & & & \\
\hline 10 & & Ryazan & 33 & 11 & 33 & + & + & + & + & + & + & + & + & + & & + & & & & + & & & \\
\hline 11 & & Belgorod & 30 & 4 & 13 & + & + & + & & & & + & & & & & & & & & & & \\
\hline 12 & $\bar{O}$ & Tambov $^{3)}$ & 29 & 7 & 24 & + & + & + & & + & & & & & + & + & & & & & & & \\
\hline 13 & & Lipetsk & 28 & 8 & 29 & + & + & + & + & + & + & + & & & + & & & & & & & & \\
\hline 14 & & Voronezh & 23 & 7 & 30 & + & + & + & & + & + & + & & + & & & & & & & & & \\
\hline 15 & & Vladimir $^{4)}$ & 30 & 10 & 33 & + & + & + & + & + & & & + & & + & & & & & + & & + & \\
\hline 16 & $\stackrel{\infty}{=}$ & Yaroslavl $^{5)}$ & 25 & 16 & 64 & + & + & + & + & & + & + & + & + & & + & + & & & + & & & \\
\hline 17 & $\Xi$ & Ivanovo & 20 & 11 & 55 & + & + & + & + & + & + & + & & + & + & & & & + & & & + & \\
\hline 18 & & Kostroma & 18 & 8 & 44 & + & + & + & + & + & + & & + & + & & & & & & & & & \\
\hline $\mathrm{Ce}$ & ntra & al Federal District & 50 & 32 & 64 & 18 & 16 & 15 & 12 & 11 & 9 & 7 & 7 & 6 & 5 & 4 & 3 & 3 & 3 & 3 & 2 & 2 & 2 \\
\hline
\end{tabular}


Chemical pressure on water objects causes substantial health risks not only directly via drinking water consumption but also indirectly via adverse effects produced by variable chemicals on food chains that include exploited water flora, fauna, fish resources, agricultural, vegetative, and animal products. Eventually anything that pollutes the environment one way or another returns to people. We can give some typical examples of such ecological water-food chains when contamination causes serious pathologies, even with fatal outcomes; they are Minamata disease (when methyl mercury migrates from water into water flora and fish and then into a human body) and Itai-Itai disease (when $\mathrm{Cd}$ migrates out of water into rice and then into a human body).

As surface water objects are intensely contaminated, and hundreds of chemicals are constantly detected both in these objects and in drinking water taken from communal water supply systems, people tend to switch to bottled water taken from sources that have not yet been contaminated by anthropogenic activities. Bottled drinking water taken from mostly underground water sources is becoming the most popular and the most widely consumed water product.

Drinking water as a food product should not only be pure as per its chemical and microbe parameters but also contain biogenic macro- and micro-elements that are essential for life activity. On one hand, completely desalinated water is not suitable for permanent consumption; on the other hand, when certain mineral components are not consumed in sufficient quantities with daily ration (for example, $\mathrm{Ca}, \mathrm{Mg}, \mathrm{J}, \mathrm{F}$ ), water can supply them into a human body [12]. This statement was fixed in the Order by Rospotrebnadzor No. 5 dated July 11, 2000, and then in the SanitaryEpidemiologic Requirements 2.1.4.1116-02 "Drinking water. Hygienic requirements to bottled water quality. Quality control" ${ }^{2}$ and the Methodical Guidelines 2.1.4.1184- $03^{3}$ on implementation and application of this document approved by the RF Ministry of Justice, as well as in the Interstate Standard R 521092003 "Bottled drinking water. Overall technical conditions" (the $2^{\text {nd }}$ edition issued as GOST 32220-2013) ${ }^{4}$, and in "The Unified sanitary-epidemiologic and hygienic requirements to goods that are subject to sanitary-epidemiologic surveillance (control)" approved by the Customs Union Commission, the Decision No.299 dated May 28, $2010^{5}$.

Over the last decades a necessity to supply consumers with natural high quality water has led to a drastic growth in bottled water production, both in Russia and abroad $[12,13]$. Approximately $64 \%$ of such water is consumed in Europe; $21 \%$, in the USA; 3.5\%, in the eastern countries; $11.5 \%$, in all other regions. Domestic bottled drinking water appeared on the Russian market more than 20 years ago; it has become a truly mass product consumed everywhere. By now, consumption of bottled drinking water in Russia has grown from 5 liters per man a year to 5 liters per man a week. Bottled drinking water market is one of the most rapidly growing consumer markets in Russia. As per data provided by RBK group, it has been growing by $15-16 \%$ annually over recent years. Recently, a range of bottled drinking and mineral water has increased substantially. There are manufacturers of bottled water in practically every Russian region $[13,14]$.

\footnotetext{
${ }^{2}$ On adjustment of drinking water quality as per biogenic elements concentration: The Order by the RF Chief Sanitary Inspector No.5 dated July 17, 2000. [web-source]. - URL: http://www.businesspravo.ru/Docum/DocumShow_DocumID_17027.html (date of visit June 05, 2018).

${ }^{3}$ MG 2.1.4.1184-03. Drinking water. Hygienic requirements to bottled water quality. Quality control: methodical guidelines for implementation and application of sanitary-epidemiologic rules and standards fixed in the SER 2.1.4. 1116-02 [websource]. - URL: https://znaytovar.ru/gost/2/MU 214118403 Metodicheskie uka.html (date of visit June 05, 2018).

${ }^{4}$ GOST 32220-2013. Bottled drinking water. Overall technical conditions [web-source] // KODEKS: an electronic fund of legal and reference documentation. - URL: http://docs.cntd.ru/document/1200107341 (date of visit August 05, 2018).

${ }^{5}$ The Unified sanitary-epidemiologic and hygienic requirements to goods that are subject to sanitary-epidemiologic surveillance (control) (last edited on May 10, 2018) [web-source] // KODEKS: an electronic fund of legal and reference documentation. - URL:http://docs.cntd.ru/document/902249109 (date of visit August 05, 2018).
} 
Requirements to bottled drinking water various categories (first class water, presafety are stricter than to water taken from mium water, and water for children nutrition centralized water supply systems $[12,15]$; or so called "drinking water for children") these requirements differ for water from (Tables 3 and 4).

Table 3

Regulated organic water pollutants

\begin{tabular}{|c|l|c|c|c|c|}
\hline \multirow{2}{*}{ No. } & \multirow{2}{*}{ Parameter } & \multirow{2}{*}{$\begin{array}{c}\text { Drinking water } \\
\text { safety parame- } \\
\text { ters, mg/l, } \\
\text { not higher }\end{array}$} & \multicolumn{2}{|c|}{$\begin{array}{c}\text { Stricter parameters for bottled drinking water, } \\
\text { mg/l, not higher }\end{array}$} \\
\cline { 4 - 6 } & & 0.00001 & $0.000005 \downarrow(2$ times $)$ & $0.000002 \downarrow(5$ times $)$ & 0.000002 \\
\hline 1 & Benzpyrene & 0.03 & $0.01 \downarrow(3$ times $)$ & $0.001 \downarrow(30$ times $)$ & 0.001 \\
\hline 2 & Bromdichloromethane & 0.1 & $0.02 \downarrow(5$ times $)$ & $0.001 \downarrow(100$ times $)$ & 0.001 \\
\hline 3 & Bromoform & 0.03 & $0.01 \downarrow(3$ times $)$ & $0.001 \downarrow(30$ times $)$ & 0.001 \\
\hline 4 & Dibromochloromethane & 0.05 & $0.025 \downarrow(2$ times $)$ & 0.025 & 0.025 \\
\hline 5 & Formaldehyde & $0.06(0.2)$ & $0.03 \downarrow(2-6.7$ times $)$ & $0.001 \downarrow(60-200$ times $)$ & 0.001 \\
\hline 6 & Chloroform & 0.002 & 0.002 & $0.001 \downarrow(2$ times $)$ & 0.001 \\
\hline 7 & Chlorinated carbon & 0.1 & $0.05 \downarrow(2$ times $)$ & $0.01 \downarrow(10$ times $)$ & 0.01 \\
\hline 8 & Petroleum products & 0.002 & $0.0005 \downarrow(4$ times $)$ & $0.0002 \downarrow(10$ times $)$ & 0.0002 \\
\hline 9 & Lindane & 0.002 & $0.0002 \downarrow(10$ times $)$ & $0.00005 \downarrow(4$ times $)$ & 0.00005 \\
\hline 10 & Atrazine & 0.002 & $0.0005 \downarrow(4$ times $)$ & $0.0002 \downarrow(2.5$ times $)$ & 0.0002 \\
\hline 11 & DDT (sum of isomers $)$ & 0.03 & $0.001 \downarrow(30$ times $)$ & 0.001 & 0.001 \\
\hline 12 & 2,4 D & 1 & $0.0002 \downarrow(5000$ times $)$ & $0.00005 \downarrow(4$ times $)$ & 0.0002 \\
\hline 13 & Simazine & 0.05 & $0.00005 \downarrow(1000$ times $)$ & $0.00002 \downarrow(2.5$ times $)$ & 0.00002 \\
\hline 14 & Heptachlor & & & & \\
\hline
\end{tabular}

Table 4

Regulated mineral components in water

\begin{tabular}{|c|c|c|c|c|c|}
\hline \multirow[t]{2}{*}{ No. } & \multirow[t]{2}{*}{ Parameter } & \multirow{2}{*}{$\begin{array}{l}\text { Drinking water } \\
\text { safety parameters, } \\
\text { mg/l, not higher }\end{array}$} & \multicolumn{3}{|c|}{$\begin{array}{l}\text { Stricter parameters for bottled drinking water, } \\
\mathrm{mg} / \mathrm{l} \text {, not higher, (mg/l, within limit) }\end{array}$} \\
\hline & & & 1 категории & Высшей категории & Детских \\
\hline 1 & Nitrites $\left(\mathrm{NO}_{2}\right)$ & 3.3 & $0.5 \downarrow(6.6$ times $)$ & $0.005 \downarrow(660$ times $)$ & 0.005 \\
\hline 2 & Aluminum (Al) & $0.2(0.5)$ & $0.1 \downarrow(2-5$ times $)$ & 0.1 & 0.1 \\
\hline 3 & Ammonia (NH) & 1.5 & $0.1 \downarrow(15$ times $)$ & $0.05 \downarrow$ (30 times) & 0.05 \\
\hline 4 & Manganese (Mn) & $0.1(0.5)$ & $0.05 \downarrow(2-10$ times $)$ & 0.05 & 0.05 \\
\hline 5 & Sulfates & 500 & $250 \downarrow(2$ times $)$ & $150 \downarrow(3.3$ times $)$ & 150 \\
\hline 6 & Chlorides & 350 & $250 \downarrow$ (1.4 times) & $150 \downarrow$ (2.3 times $)$ & 150 \\
\hline 7 & Barium (Ba) & 0.7 & 0.7 & $0.1 \downarrow$ (7 times) & 0.1 \\
\hline 8 & Boron (B) & 0.5 & 0.5 & $0.3 \downarrow(1.7$ times $)$ & 0.3 \\
\hline 9 & Bromide $(\mathrm{Br})$ & 0.2 & 0.2 & $0.1 \downarrow(2$ times $)$ & 0.1 \\
\hline 10 & Arsenic (As) & 0.01 & 0.01 & $0.006 \downarrow(1.7$ times $)$ & 0.006 \\
\hline 11 & Lead $(\mathrm{Pb})$ & 0.01 & 0.01 & $0.005 \downarrow(2$ times $)$ & 0.005 \\
\hline 12 & Chromium (Cr) & 0.05 & 0.05 & $0.03 \downarrow$ (1.7 times $)$ & 0.03 \\
\hline 13 & Cyanides & 0.07 & $0.035 \downarrow(2$ times $)$ & 0.035 & 0.035 \\
\hline 14 & Zinc (Zn) & 5 & 5 & $3 \downarrow(1.7$ times $)$ & 3 \\
\hline 15 & Cadmium (Cd) & 0.002 & $0.001 \downarrow$ (2 times $)$ & 0.001 & $\begin{array}{l}0.0005 \downarrow \\
(2 \text { times })\end{array}$ \\
\hline 16 & Mercury (Hg) & 0.001 & $0.0005 \downarrow(2$ times $)$ & $0.0002 \downarrow(5$ times $)$ & $\begin{array}{l}0.0001 \downarrow \\
(2 \text { times })\end{array}$ \\
\hline
\end{tabular}




\begin{tabular}{|c|c|c|c|c|c|}
\hline 17 & Sodium (Na) & 200 & 200 & $100 \downarrow$ (2 times) & $\begin{array}{c}20 \downarrow \\
(5 \text { times) }\end{array}$ \\
\hline 18 & Nitrates $\left(\mathrm{NO}_{3}\right)$ & 45 & $20 \downarrow$ (2.3 times $)$ & $10 \downarrow$ (4.5 times) & $\begin{array}{c}5 \downarrow \\
(2 \text { times) }\end{array}$ \\
\hline 19 & Selenium (Se) & 0.01 & 0.01 & 0.01 & $\begin{array}{c}0.005 \downarrow \\
(2 \text { times) }\end{array}$ \\
\hline 20 & Bicarbonates $\left(\mathrm{HCO}_{3}\right)$ & 400 & 400 & $30-400$ (13 times) & $30-300 \downarrow$ \\
\hline 21 & Potassium (K) & - & 20 & $2-20$ & $2-10 \downarrow$ \\
\hline 22 & Calcium $(\mathrm{Ca})$ & - & 130 & $25-80$ & $25-60 \downarrow$ \\
\hline 23 & Magnesium (Mg) & - & 50 & $5-50$ & $5-35 \downarrow$ \\
\hline 24 & Fluorides (F) & 1.5 & 1.5 & $\begin{array}{c}0.6-1.2 \downarrow \\
(2.5-1.3 \text { times })\end{array}$ & $0.6-1 \downarrow$ \\
\hline 25 & Hardness, mg-eqv./1 & 7 & 7 & $1.5-7 \downarrow(4.7$ times $)$ & $1.5-6 \downarrow$ \\
\hline 26 & Alkalinity, mg-eqv./l & 6.5 & 6.5 & $0.5-6.5 \downarrow(13$ times $)$ & $0.5-5 \downarrow$ \\
\hline 27 & $\begin{array}{l}\text { Salinity, mg/l, within } \\
\text { limits }\end{array}$ & $1,000(1,500)$ & $1,000 \downarrow(1.5$ times $)$ & $\begin{array}{l}200-500 \downarrow \\
(5-2 \text { times })\end{array}$ & $200-500$ \\
\hline 28 & $\begin{array}{l}\text { Iodine }(\mathrm{J}), \mathrm{mg} / \mathrm{l} \\
\text { within limits }\end{array}$ & 0.125 & 0.125 & $\begin{array}{l}0.04-0.06 \downarrow \\
(3-2 \text { times })\end{array}$ & $0.04-0.06$ \\
\hline
\end{tabular}

Bottled drinking waters differ greatly as per their safety parameters and qualitative properties. These differences are caused by additional criteria being introduced: quality should be stable over time (as it takes much longer time for bottled drinking water to be supplied to an end customer; water from a centralized water supply system is delivered within much shorter time period, from several hours to 2-3 days, but bottled water can be delivered to an end consumer within a period from 3,6 or 12 months to even 2-5 years after it was manufactured); water should be physiologically valuable (drinking water should not contain any adverse chemical admixtures that are hazardous for health, but it should contain certain biogenic elements necessary for proper life activity, especially those that are hard to find in food products or their quantity in food is insufficient). It is also important to note that there is a much longer list of parameters that are obligatory for examination fixed for bottled water (there are 56 priority parameters for water taken from centralized water supply systems, but there are 93 such parameters for bottled water) [16].

Bottled drinking waters from the first category are regulated by much stricter standards (from 2 to 5,000 times stricter) against water from centralized water supply systems as per 24 parameters for contents of chemicals that belong to the 1 st and 2 nd hazard category. Bot- tled waters from the premium category are regulated by even stricter standards than the waters from the first category as per 17 parameters; such waters are optimal in terms of being physiologically valuable (within minimum necessary and maximum permissible levels) as per 9 parameters for contents of vitally essential biogenic elements. Bottled drinking waters from the premium category are not only as safe as possible but they also produce preventive and health-improving effects. They are recommended to be consumed by children, pregnant women, ill people, sportsmen, and people who work under high physical loads, that is, by consumers who have the highest need for biogenic elements (Figure 1).

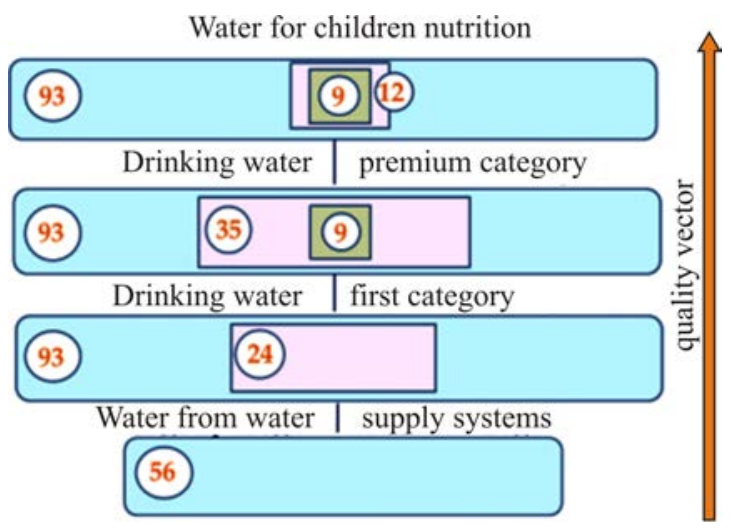

Figure 1. The pyramid for bottled drinking waters quality as per safety parameters and physiological value 
Waters for children nutrition are basically to meet the same requirements as the premium drinking waters but they should not contain $\mathrm{Cd}$ and $\mathrm{Hg}$ even in minimum quantities, and maximum permissible concentrations of nitrates, $\mathrm{Se}, \mathrm{Na}, \mathrm{K}, \mathrm{Ca}, \mathrm{Mg}, \mathrm{F}$, and bicarbonates in them are also adjusted. Besides, parameters of water hardness and alkalinity fixed for such waters are optimal for a child body.
The above mentioned differences are based on criterial calculations made with application of methodology for assessing population and individual risks, taking into account age-related peculiarities of water consumption and development of a body, and comparative analysis performed on more than 850 bottled waters distributed on the Russian market (Table 6).

Table 5

Bottled drinking water production, including premium water, in the RF regions

Total/Premium water

\begin{tabular}{|c|c|c|c|c|c|c|}
\hline $\begin{array}{c}\text { Severo- } \\
\text { Zapadniy } \\
\text { Federal District }\end{array}$ & $\begin{array}{c}\text { Zhentralniy } \\
\text { Federal } \\
\text { District } \\
\end{array}$ & $\begin{array}{l}\text { Yuzhniy } \\
\text { Federal } \\
\text { District } \\
\end{array}$ & $\begin{array}{c}\text { Privolzhskiy } \\
\text { Federal } \\
\text { District } \\
\end{array}$ & $\begin{array}{l}\text { Uralskiy } \\
\text { Federal } \\
\text { District } \\
\end{array}$ & $\begin{array}{c}\text { Sibirskiy } \\
\text { Federal } \\
\text { District } \\
\end{array}$ & $\begin{array}{c}\text { Dal'nevostoch- } \\
\text { niy Federal Dis- } \\
\text { trict }\end{array}$ \\
\hline Arkhangelsk $9 / 0$ & $\begin{array}{c}\text { Belgorod - } \\
1 / 1\end{array}$ & $\begin{array}{c}\text { Astrakhan } \\
1 / 0\end{array}$ & Kirov 5/1 & Kurgan $5 / 2$ & Altai $20 / 2$ & $\begin{array}{c}\text { Amur } \\
6 / 1\end{array}$ \\
\hline Vologda $-7 / 1$ & $\begin{array}{c}\text { Bryansk - } \\
5 / 1\end{array}$ & $\begin{array}{c}\text { Volgograd - } \\
12 / 2\end{array}$ & $\begin{array}{l}\text { Nizhniy Nov- } \\
\text { gorod } 29 / 3\end{array}$ & $\begin{array}{c}\text { Sverdlovsk - } \\
33 / 2\end{array}$ & $\begin{array}{c}\text { Transbaikal } \\
2 / 0\end{array}$ & $\begin{array}{c}\text { Kamchatka } \\
2 / 1\end{array}$ \\
\hline Kaliningrad 4/1 & $\begin{array}{c}\text { Vladimir - } \\
10 / 1\end{array}$ & $\begin{array}{c}\text { Krasnodar } \\
37 / 5\end{array}$ & Orenburg 20/2 & Tyumen $30 / 3$ & $\begin{array}{c}\text { Irkutsk } \\
19 / 2\end{array}$ & Magadan $1 / 0$ \\
\hline $\begin{array}{c}\text { Murmansk } \\
1 / 0\end{array}$ & Voronezh $8 / 2$ & $\begin{array}{c}\text { Adygei } \\
7 / 1\end{array}$ & $\begin{array}{c}\text { Penza } \\
8 / 1\end{array}$ & $\begin{array}{c}\text { Chelyabinsk- } \\
11 / 2\end{array}$ & $\begin{array}{c}\text { Kemerovo - } \\
6 / 1\end{array}$ & $\begin{array}{c}\text { Primorye } \\
23 / 3\end{array}$ \\
\hline Novgorod $-8 / 2$ & Ivanovo $-3 / 1$ & $\begin{array}{l}\text { Rostov } \\
32 /(4\end{array}$ & $\begin{array}{c}\text { Perm } \\
16 / 1\end{array}$ & & $\begin{array}{c}\text { Krasnoyarsk } \\
19 / 4\end{array}$ & $\begin{array}{c}\text { Yakutia } \\
16 / 1\end{array}$ \\
\hline $\begin{array}{l}\text { Pskov- } \\
8 / 3\end{array}$ & $\begin{array}{c}\text { Kaluga } \\
8 / 3\end{array}$ & $\begin{array}{c}\text { Kabardino- } \\
\text { Balkaria } \\
1 / 1\end{array}$ & $\begin{array}{l}\text { Bashkorto- } \\
\text { stan - 34/2 }\end{array}$ & & $\begin{array}{c}\text { Novosibirsk } \\
12 / 3\end{array}$ & Sakhalin $2 / 0$ \\
\hline $\begin{array}{c}\text { Karelia - } \\
1 / 1\end{array}$ & Kostroma 4/1 & $\begin{array}{c}\text { Karachai- } \\
\text { Cherkess } \\
5 / 4\end{array}$ & Mari El - 11/1 & & $\begin{array}{c}\text { Omsk } \\
10 / 0\end{array}$ & $\begin{array}{c}\text { Khabarovsk } \\
17 / 0\end{array}$ \\
\hline $\begin{array}{l}\text { Komi - } \\
6 / 1\end{array}$ & $\begin{array}{c}\text { Kursk } \\
9 / 5\end{array}$ & $\begin{array}{c}\text { Dagestan } \\
2 /(1\end{array}$ & $\begin{array}{c}\text { Mordovia } \\
3 / 0\end{array}$ & & $\begin{array}{c}\text { Buryatia } \\
5 / 1\end{array}$ & $\begin{array}{c}\text { Jewish Auto- } \\
\text { nomous Region } \\
2 / 0\end{array}$ \\
\hline \multirow[t]{9}{*}{$\begin{array}{c}\text { Leningrad - } \\
21 / 1 \\
\end{array}$} & $\begin{array}{c}\text { Lipetsk } \\
6 / 4\end{array}$ & $\begin{array}{l}\text { North Ossetia } \\
\text { - Alania 4/0 }\end{array}$ & $\begin{array}{c}\text { Tatarstan - } \\
28 / 6 \\
\end{array}$ & & $\begin{array}{c}\text { Khakassia } \\
2 / 0\end{array}$ & Chukchi $-1 / 0$ \\
\hline & $\begin{array}{c}\text { Moscow - } \\
59 / 22 \\
\end{array}$ & $\begin{array}{c}\text { Stavropol } \\
18 / 6 \\
\end{array}$ & $\begin{array}{c}\text { Samara } \\
20 / 6 \\
\end{array}$ & & $\begin{array}{c}\text { Tomsk } \\
6 / 0 \\
\end{array}$ & \\
\hline & Orel 2/0 & & Saratov $-12 / 5$ & & & \\
\hline & $\begin{array}{c}\text { Ryazan } \\
4 / 0\end{array}$ & & $\begin{array}{c}\text { Udmurtia } \\
7 / 1\end{array}$ & & & \\
\hline & $\begin{array}{c}\text { Smolensk - } \\
8 / 6 \\
\end{array}$ & & $\begin{array}{c}\text { Ul'yanovsk } \\
6 / 3 \\
\end{array}$ & & & \\
\hline & Tambov $-4 / 4$ & & $\begin{array}{c}\text { Chvashia } \\
4 / 0\end{array}$ & & & \\
\hline & Tver' $18 / 4$ & & & & & \\
\hline & Tula $12 / 2$ & & & & & \\
\hline & $\begin{array}{c}\text { Yaroslavl - } \\
9 / 0\end{array}$ & & & & & \\
\hline Total: $65 / 10$ & Total: $170 / 54$ & Total:119/24 & Total 203/32 & $\sum 79 / 9$ & $\sum 101 / 13$ & Total $70 / 6$ \\
\hline \multicolumn{4}{|c|}{ European part of the RF $557-70 \%$} & \multicolumn{3}{|c|}{ Asian part of the RF $250-30 \%$} \\
\hline
\end{tabular}


Bottled drinking water from the first category guarantees greater chemical safety and provides better health preservation. Premium waters and waters for children nutrition are practically free from any adverse chemicals (xenobiotics) and it is confirmed by all the existing analysis techniques; that is, such waters are practically completely safe. They are also the most useful mass product for health as they contain biogenic elements that are necessary for a body; as a result, these waters not only preserve health but also improve it considerably.

Greater epidemiologic safety was also a significant part in regulating quality of bottled drinking waters. To achieve this goal, experts adjusted techniques for control over epidemic safety of bottled drinking water by introducing a new and more reliable integral parameter for glucose+ bacteria (GPB) into SER $^{6}$. This parameter comprises the whole group of bacteria from Enterobacteriaceae family, that is, it guarantees that examined water doesn't contain either lactose+ bacteria (E.coli, total coliforms, or thermotolerant coliforms) or pathogenic (Salmonella) and potentially pathogenic bacteria that don't ferment lactose. The parameter is based on two basic signs, a differential sign of glucose fermentation and negative oxidase test. These signs are genetically native for the whole Entero- bacteriaceae family and it provides stability of the GPB parameter as a necessary property of an indicator microorganism thus making it truly reliable in terms of water quality control [17-19]. Tables 7 and 8 show results of comparative analysis performed on existing sanitary-indicator parameters for epidemiologic safety of water.

Reliability of the parameter was convincingly conformed by long-term research results. Thus, in 2013 Zhuravlev [20] determined a long-term period during which salmonella survived in drinking water (42 days in centralized water supply systems). Indicator value remained only for a group of glucose + coliforms as their vegetating dynamics completely corresponded to that of salmonella. A parameter of thermotolerant E.coli didn't provide epidemic safety of water under the same conditions as regards salmonella as E.coli were detected in water during a shorter period of time (28 days), and salmonella were detected when E.coli were absent. It was detected during an experiment that salmonella were more resistant to chlorine than E.coli and total coliforms. Salmonellas died when a contact lasted for 4 hours, while it took E.coli only 1 hour, and total coliforms 2 hours, to die. Glucose+ coliforms died after 4 hours, just like salmonella, but indicator value as regards pathogenic bacteria still persisted.

Table 7

Comparative characteristics of coliform parameters

\begin{tabular}{|c|c|c|c|c|}
\hline Parameters & Glucose + coliforms & Total coliforms & $\begin{array}{c}\text { Thermotolerant } \\
\text { coliforms }\end{array}$ & E.coli \\
\hline $\begin{array}{l}\text { Identification } \\
\text { signs }\end{array}$ & $\begin{array}{l}\text { Glucose, acid } \\
\text { and gas, } 37^{\circ} \mathrm{C}\end{array}$ & $\begin{array}{l}\text { Lactose, acid, } \\
\text { and gas, } 37^{\circ} \mathrm{C}\end{array}$ & $\begin{array}{l}\text { Lactose, acid, } \\
\text { and gas, } 44^{\circ} \mathrm{C}\end{array}$ & $\begin{array}{l}\text { Lactose, acid, and } \\
\text { gas, } 44^{\circ} \mathrm{C} \text {, indole }\end{array}$ \\
\hline \multirow{4}{*}{$\begin{array}{l}\text { Stems from } \\
\text { Enterobacte- } \\
\text { riaceae } \\
\text { family }\end{array}$} & Escherichia & Escherichia & Escherichia & Escherichia \\
\hline & $\begin{array}{c}\text { Klebsiella, Citobacter } \\
\text { Enterobacter }\end{array}$ & $\begin{array}{c}\text { Klebsiella, Citobacter } \\
\text { Enterobacter }\end{array}$ & Klebsiella & \\
\hline & $\begin{array}{c}\text { Rahnella } \\
\text { Buttiauxella }\end{array}$ & \begin{tabular}{c|} 
Rahnella \\
Buttiauxella
\end{tabular} & \multirow{2}{*}{$\begin{array}{l}\text { Water with } \\
\text { standard } \\
\text { quality }\end{array}$} & \\
\hline & $\begin{array}{l}\text { Gafnia, Morganella Edward- } \\
\text { siella, Providencia, Serattia } \\
\text { Proteus, Salmonella }\end{array}$ & & & \\
\hline $\begin{array}{l}\text { Essence of a } \\
\text { sign }\end{array}$ & $\begin{array}{l}\text { Wide-scale, hygienically } \\
\text { reliable, integral, provides } \\
\text { epidemiologic safety }\end{array}$ & $\begin{array}{c}\text { Less wide, integral, } \\
\text { not stable }\end{array}$ & $\begin{array}{l}\text { Narrow, not } \\
\text { stable }\end{array}$ & $\begin{array}{l}\text { The most narrow, } \\
\text { stable }\end{array}$ \\
\hline
\end{tabular}

\footnotetext{
${ }^{6}$ On implementation of sanitary-epidemiologic rules and standards "Drinking water. Hygienic requirements to quality of bottled water. Quality control. SER 2.1.4.1116-02" (together with "SER 2.1.4.1116-02. 2.1.4. Drinking water and water supply to settlements. Drinking water": The Order by the RF Chief Sanitary Inspector dated March 19, 2002 No. 12 (last edited on June 28, 2010) [websource] // KonsultantPlus. - URL: http://www.consultant.ru/document/cons_doc_LAW_6030/ (date of visit September 01, 2018).
} 
Epidemiologic reliability of identification techniques: comparative assessment

\begin{tabular}{|c|c|}
\hline Identification as per lactose (LPB) & Identification as per glucose (GPB) \\
\hline $\begin{array}{l}\text { Sporadic morbidity on the south of the country caused by opportun- } \\
\text { istic pathogenic bacteria (Kattakurgan, Azov) }\end{array}$ & \multirow{4}{*}{$\begin{array}{l}\text { Episodes and sporadic morbidity } \\
\text { were not registered during } 30 \text { years } \\
\text { when a standard parameter for } \\
\text { water quality per State Standard } \\
2874-73 \text { was applied }\end{array}$} \\
\hline Episodes of enteric infections in Moscow region (Protvino, Oktyabrskiy) & \\
\hline $\begin{array}{l}\text { Water-related episodes abroad when coliforms were not detected } \\
\text { Liverpool (1965) Seligmanm Reiteer } \\
\text { Riverside (1968) Yallager, Spino }\end{array}$ & \\
\hline $\begin{array}{l}\text { More than half of } 126 \text { water-related episodes in the USA occurred } \\
\text { when there were no coliforms in drinking water }\end{array}$ & \\
\hline
\end{tabular}

A modified procedure for determining glucose+ bacteria, apart from being more informative, streamlines sanitary-microbiologic analysis (making it approximately 1 day shorter) (Table 9). There is also a substantiated necessity to perform microbiologic control over blue pus bacillus occurrence.

Stricter requirements to quality and safety of drinking water call for regulatory base updating [21-23]. Today we should indicate that there are some incorrect positions fixed in subordinate documents of the sanitary legislation. For example, "mineral water" and "drinking water" are considered to be identical notions in some of them and it contradicts to conceptual determination of such waters in well-known encyclopedias and reference books. Then, a new term, "mineral table drinking water" was introduced into world practice; certain documents allow 10 times higher concentration of xenobiotics belonging to the 1st and 2nd hazard category $(\mathrm{Hg}, \mathrm{Pb}$, and $\mathrm{As})$ for such water as compared with standards fixed even for water taken from communal water supply systems. Such water can cause serious health risks not only for children but also for adults and it can't be permitted for consumption as "Water for children nutrition".

Table 10 shows some recommendations on adjustments that should be made in certain subordinate acts. We should also note that there are a lot of uncertainty factors related to separation of an internationally accepted concept and term "mineral water" into Russian ones "mineral drinking therapeutic water" and "mineral drinking therapeutic and table water", not to mention an absurd "table mineral drinking water" concept. It is also confirmed by substantial differences in a number of controlled parameters for such waters in comparison with existing Russian and international regulatory documents (Figure 2).

Table 9

Techniques for coliform bacteria determination: comparative characteristics

\begin{tabular}{|c|c|c|c|}
\hline \multirow{3}{*}{$\begin{array}{c}\text { A day } \\
\text { of sample } \\
\text { inoculation }\end{array}$} & ISO 9308-1:2000 technique & MG 4.2.1018-01 technique & Developed quick test \\
\hline & \multicolumn{3}{|c|}{ Inoculation via membrane filtration } \\
\hline & \multicolumn{3}{|c|}{ Incubation for $18-24$ hours under $37^{\circ} \mathrm{C}$ in a lactose selective medium } \\
\hline $\begin{array}{l}\text { After } \\
24 \text { hours }\end{array}$ & $\begin{array}{l}\text { Selective inoculation of co- } \\
\text { lonies on nonselective agar } \\
\text { Incubation for } 18-24 \text { hours } \\
\text { under } 37^{\circ} \mathrm{C}\end{array}$ & $\begin{array}{l}\text { Selective oxidase test on colonies } \\
\text { Microscopy after Gram stain } \\
\text { Fermentation in a lactose medi- } \\
\text { um for } 24-48 \text { hours under } 37^{\circ} \mathrm{C}\end{array}$ & $\begin{array}{l}\text { Oxidase test performed simul- } \\
\text { taneously on all the colonies on } \\
\text { a membrane filter. } \\
\text { Final results after } 18-24 \text { hours }\end{array}$ \\
\hline $\begin{array}{l}\text { After } \\
48 \text { hours }\end{array}$ & $\begin{array}{l}\text { Determination of oxidase } \\
\text { activity }\end{array}$ & $\begin{array}{l}\text { Preliminary accounting of gas- } \\
\text { sing }\end{array}$ & \\
\hline $\begin{array}{l}\text { After } \\
72 \text { hours }\end{array}$ & & Final accounting of gassing & \\
\hline \multirow[t]{2}{*}{ TOTAL } & 48 hour duration & $\begin{array}{l}3 \text { day duration without taking } \\
\text { into account biochemical prop- } \\
\text { erties variability }\end{array}$ & $\begin{array}{l}\text { 18-24 hour duration; precise } \\
\text { differentiation of colonies }\end{array}$ \\
\hline & \multicolumn{2}{|c|}{ Results not authentic due to subjective selection of colonies } & No subjective assessments \\
\hline
\end{tabular}


Documents regulating safety of drinking mineral waters that require adjustments

\begin{tabular}{|c|c|c|c|}
\hline No. & Title of a document & Parameters under control & Required adjustments \\
\hline 1 & $\begin{array}{l}\text { State Standard 13273-88 "Min- } \\
\text { eral drinking therapeutic waters } \\
\text { and mineral drinking therapeu- } \\
\text { tic and table waters. Technical } \\
\text { conditions" }\end{array}$ & $\begin{array}{l}>70 \text { parameters, contents of } \\
8 \text { biogenic elements are } \\
\text { regulated. } \\
\text { Safety parameters are not } \\
\text { regulated. }\end{array}$ & $\begin{array}{l}\text { 1. The term "drinking" is not substan- } \\
\text { tiated for simultaneous introduction } \\
\text { together with the term "mineral" for } \\
\text { therapeutic and therapeutic and table } \\
\text { waters }\end{array}$ \\
\hline 2 & $\begin{array}{l}\text { SER 2.3.2.1078-01. "Food raw } \\
\text { materials and food products". } \\
\text { item 1.8.2. "Waters; drinking } \\
\text { ones, mineral natural table ones, } \\
\text { therapeutic and table ones, } \\
\text { therapeutic ones" }\end{array}$ & $\begin{array}{l}9 \text { safety parameters, } 3 \text { out of } \\
\text { them higher than MPC: } \\
\mathrm{Pb}-0.1 \mathrm{mg} / \mathrm{dm}^{3} \text { (10 times } \\
\text { higher) } \\
\left.\mathrm{Cd}-0.01 \mathrm{mg} / \mathrm{dm}^{3} \text { ( } 5 \text { times }\right) \\
\mathrm{Hg}-0.005 \mathrm{mg} / \mathrm{dm}^{3}(10 \\
\text { times) }\end{array}$ & $\begin{array}{l}\text { 1. }-\ll-\ll-\ll-«-\ll \\
\text { 2. Introduction of the term "table" is } \\
\text { not substantiated (water is "therapeu- } \\
\text { tic and table" in its essence) } \\
\text { 3. Introduction of mineral therapeutic } \\
\text { waters and mineral therapeutic and } \\
\text { table waters into this SER is not sub- } \\
\text { stantiated }\end{array}$ \\
\hline 3 & $\begin{array}{l}\text { The Customs Union Technical } \\
\text { regulations CU TR 021/2011 } \\
\text { "On food products safety". } \\
\text { Appendix 3. "Hygienic re- } \\
\text { quirements to food products } \\
\text { safety", item } 8 \text { "Beverages" }\end{array}$ & $\begin{array}{l}3 \text { safety parameters higher } \\
\text { thamnMPC: } \\
\mathrm{Pb}-0.1 \mathrm{mg} / \mathrm{dm}^{3} \text { (10 times } \\
\text { higher) } \\
\mathrm{Cd}-0.01 \mathrm{mg} / \mathrm{dm}^{3} \text { (5 times) } \\
\mathrm{Hg}-0.005 \mathrm{mg} / \mathrm{dm}^{3} \text { (10 } \\
\text { times) }\end{array}$ & $\begin{array}{l}\text { 1. The term "table" water is intro- } \\
\text { duced again. } \\
\text { 2. Mineral natural waters are unrea- } \\
\text { sonably assigned into "beverages" } \\
\text { category. } \\
\text { 3. There is no list of biogenic ele- } \\
\text { ments (water is controlled only as per } \\
3 \text { safety parameters). }\end{array}$ \\
\hline
\end{tabular}

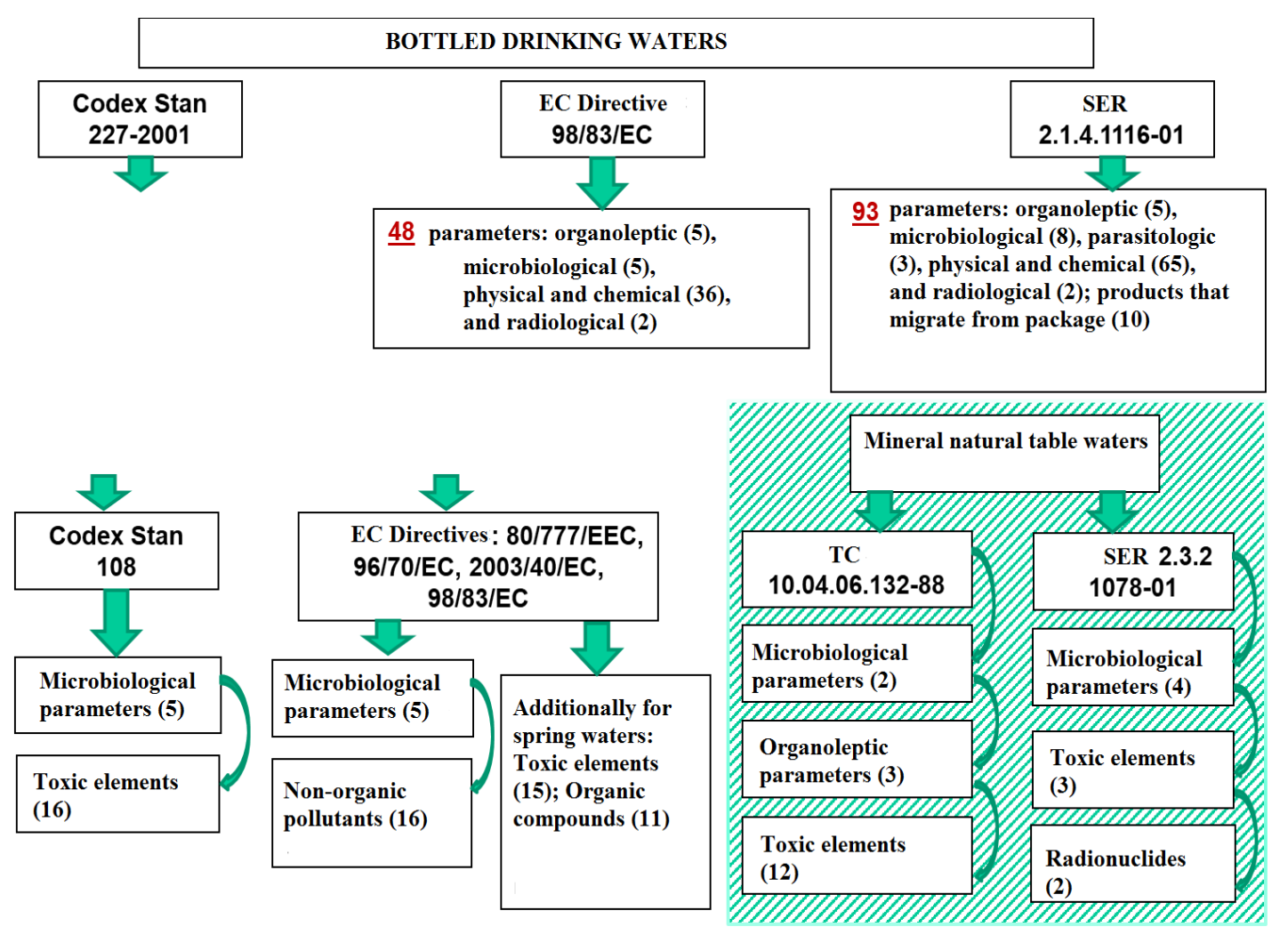

Figure 2. Regulatory documents for control over safety of different bottled waters 
Regulatory and legal base should be updated in such a way that could provide support to manufacture of high quality bottled waters including those aimed for children nutrition. When such waters were introduced into daily rations at schools and pre-school children facilities in Moscow, Barnaul, Samara, and Smolensk, their considerable health-improving effects were proven $[24,25]$.

Therefore, development of drinking water market as a segment of the overall food consumer market requires the following:
- updated regulatory and methodical base for control over quality and safety of distributed waters;

- improved systems for monitoring over epidemiologic safety based on up-to-date research techniques and tools;

- wider implementation of methodology for assessing health risks related to consumption of water with different quantitative and qualitative structure.

Funding. The research was not granted any sponsor support.

Conflict of interests. The authors state there is no any conflict of interests.

\section{References}

1. Nedachin A.E., Artemova T.Z., Dmitrieva R.A., Doskina T.V., Talaeva Yu.G., Ivanova L.V. [et al]. Problems of epidemic safety of drinking water use by the population of Russia. Gigiena $i$ sanitariya, 2005, no. 6, pp. 14-18 (in Russian).

2. Zuev E. T., Fomin G. S. Pit'evaya i mineral'naya voda. Trebovaniya mirovykh i evropeiskikh standartov $\mathrm{k}$ kachestvu i bezopasnosti [Drinking and mineral water. The requirements of world and European standards for quality and safety]. Moscow, Protektor Publ., 2003, 319 p. (in Russian).

3. Barrell R.A., Hunter P.R., Nichols G. Microbiological standards for water and their relationship to health risk. Commun. Dis. Public Health, 2000, vol. 3, no. 1, pp. 8-13.

4. Borisova N.I., Borisov A.V. Current state and problems of the sector of water supply and sanitation in the new economic development of Russia and its regions. Ekonomika i predprinimatel'stvo, 2014, vol. 49, no. 8, pp. 728-773 (in Russian).

5. Malysheva A.G., Rakhmanin Yu.A. Fiziko-khimicheskie issledovaniya i metody kontrolya veshchestv $\mathrm{v}$ gigiene okruzhayushchei sredy [Physico-chemical studies and methods for the control of substances in environmental hygiene]. Sankt-Peterburg, MPO «Professional» Publ., 2012, 717 p. (in Russian).

6. Nedachin A.E., Artemova T.Z., Ivanova L.V., Talaeva Yu.G., Bogatyreva I.A., Butorina N.N. [et al]. Improving the standard and methodological basis for bacteriological monitoring the quality of drinking water. Gigiena i sanitariya, 2007, no. 5, pp. 36-39 (in Russian).

7. Unguryanu T.N. Risk dlya zdorov'ya naseleniya pri kompleksnom deistvii veshchestv, zagryaznyayushchikh pit'evuyu vodu [The risk to public health in the complex effect of substances that pollute drinking water]. Ekologiya cheloveka, 2011, no. 3, pp. 14-20 (in Russian).

8. Bi B., Liu X., Guo X., Lu S. Occurrence and risk assessment of heavy metals in water, sediment, and fish from Dongting Lake, China. Environmental Science and Pollution, 2018, vol. 25, no. 34, pp. 34076-34090.

9. Calderon R.L. The epidemiology of chemical contaminants of drinking water. Food Chem. Toxicol., 2000, vol. 38, suppl. 1, pp. 13-20.

10. Ljung K, Vahter M. Time to re-evaluate the guideline value for manganese in drinking water? (Review). Environ Health Perspect, 2007, vol. 115, no. 11, pp. 1533-1538.

11. Turbinskii V.V., Khmelev V.A. Gigienicheskii prognoz opasnosti prirodnogo i tekhnogennogo zagryazneniya istochnikov pit'evogo vodosnabzheniya dlya zdorov'ya naseleniya v Sibiri [Hygienic forecast of the danger of natural and man-made pollution of drinking water supply sources for the health of the population in Siberia]. SWorld: Sbornik nauchnykh trudov, 2012, vol. 33, no. 3, pp. 54a-60 (in Russian).

12. Rakhmanin Yu.A., Mikhailova R.I. Razvitie proizvodstva butilirovannykh vod vysshei kategorii kachestva yavlyaetsya vazhnym napravleniem uluchsheniya pit'evogo vodosnabzheniya [The development of the production of bottled waters of the highest quality category is an important direction for improving the drinking water supply]. Voda Magazine, 2010, no. 6, pp. 32-33 (in Russian). 
13. Sevost'yanova E.M. Topical questions of mineral water production. Aktual'nye voprosy industrii napitkov, 2018, no. 2, pp. 145-148 (in Russian).

14. Lavrov K.L. O potreblenii, kachestve i bezopasnosti vody pit'evoi butilirovannoi [About consumption, quality and safety of drinking bottled water]. Konkurentosposobnost' territorii: Materialy XIX Vserossiiskogo ekonomicheskogo foruma molodykh uchenykh $i$ studentov: $v 8$ chastyakh. - Ekaterinburg, 2016, pert 7, pp. 205-208 (in Russian).

15. Sidorenko G.J., Rakhmanin Yu.A. Guidelines on Health Aspects of Water Desalination. Geneva, WHO, ETS/80.4, 60 p.

16. Zhuravlev P.V., Aleshnya V.V., Panasovets O.P., Morozova A.A., Artemova T.Z., Talaeva Yu.G. [et al]. The significance of glucose positive coliform bacteria and potentially pathogenic bacteria as an indicator of epidemiological safety of tap water. Gigiena $i$ sanitariya, 2013, no.1, pp. 56-58 (in Russian).

17. Dechesne M., Soyeux E. Assessment of source water pathogen contamination. J. Water Health, 2007, vol. 5, suppl. 1, pp. 39-50.

18. Rakhmanin Yu.A., Ivanova L.V., Artemova T.Z., Gipp E.K., Zagainova A.V., Maksimkina T.N., Krasnyak A.V., Zhuravlev P.V., Aleshnya V.V., Panasovets O.V. Distribution of bacteria of the Klebsiella strain in water objects and their value in developing of the water caused acute intestinal infections. Gigiena i sanitariya, 2016, vol. 95, no. 4, pp. 397-406 (in Russian).

19. Ambartsumyan L.I., Guba E.N., Guseva M.V., Diyanova S.N., Illarionova V.V. Problems of quality and safety of bottled drinking water. Izvestiya vysshikh uchebnykh zavedenii. Pishchevaya tekhnologiya, 2018, vol. 364, no. 4, pp. 96-99 (in Russian).

20. Belov G.V., Kasymbekov Zh.O., Azhimatova M.R., Ivanova O.K. Riski poteri kachestva butylirovannykh vod (na primere predpriyatii severa Kyrgyzstana) [Risks of loss of quality of bottled water (on the example of enterprises in the north of Kyrgyzstan)]. Meditsina Kyrgyzstana, 2014, no. 3-2, pp. 10-16 (in Russian).

21. Korotkov V.V., Dolgova A.V. Hygienic problems of bottled drinking water safety in the Lipetsk Region. Zdravookhranenie Rossiiskoi Federatsii, 2011, no. 4, pp. 28 (in Russian).

22. Sevost'yanova E.M., Lozhkomoeva M.M. Kriterii otsenki kachestva vody mineral'noi, prednaznachennoi dlya pitaniya detei razlichnykh vozrastnykh grupp [Criteria for assessing the quality of mineral water intended for the nutrition of children of different age groups]. Puti intensifikatsii proizvodstva $i$ pererabotki sel'skokhozyaistvennoi produktsii $v$ sovremennykh usloviyakh: Materialy mezhdunarodnoi nauchno-prakticheskoi konferentsii: v 2-kh chastyakh. In: V.N. Khramova ed. Volgograd, 2012, vol. 2, pp. 136-139 (in Russian).

23. Sevost'yanova E.M. Obespechenie pit'evogo rezhima v obrazovatel'nykh uchrezhdeniyakh [Providing drinking regime in educational institutions]. Voprosy pitaniya, 2014, vol. 83, no. S3, pp. 87 (in Russian).

Rakhmanin Yu.A., Mikhailova R.I. FOOD RISKS ANALYSIS AND WATER SAFETY. Health Risk Analysis, 2018, no. 4, pp. 31-42. DOI: 10.21668/health.risk/2018.4.04.eng

Received: 28.09 .2018

Accepted: 17.12 .2018

Published: 30.12 .2018 
UDC 613.2

DOI: 10.21668/health.risk/2018.4.05.eng

\section{HEALTH RISK ASSESSMENT WHEN GIVING GROUNDS FOR HYGIENIC CRITERIA OF FOOD PRODUCTS SAFETY}

\section{P.Z. Shur, N.V. Zaitseva}

Federal Scientific Center for Medical and Preventive Health Risk Management Technologies, 82 Monastyrskaya Str., Perm, 614045, Russian Federation

Safety of any product, including food, is viewed as absence of unacceptable risks for life and health. Given that, we propose methodical approaches to health risk assessment in substantiating hygienic standards for contaminants contents in food products; these standards are to be harmonized with internationally accepted principles and supplemented with a methodology recommended by the Eurasian Economic Commission. We describe approaches to assessment of product risks with application of health risk evolution modeling; when giving grounds for hygienic standards, these approaches allow to predict health risk evolution over a period during which a consumer contacts a product; to calculate risk levels for different consumer groups, including sensitive ones; to model health risk as per preset exposure scenarios.

The article contains some examples of setting hygienic requirements to contents of chemical contaminants and biological agents in food products. Thus, a hygienic standard for contents of tetracycline antibiotics in meat products was fixed taking into account consequences of gut organisms imbalance as an increased risk of digestive organs diseases, dermatitis, food allergy, or blood diseases. When a hygienic standard for ractopamine contents in meat products was being fixed, it was shown that its occurrence in any concentration that can be detected with contemporary techniques caused unacceptable health risk in a form of functional disorders in the circulatory system. Therefore, ractopamine was to be prohibited in any concentration. When maximum permissible nitrates contents in fruit and vegetable was being substantiated, experts took into account both carcinogenic risks caused by transformation of nitrates into nitrosoamines, and health risks related to methemoglobin formation. Hygienic requirements to permissible listeria contents in food products ready for consumption were substantiated taking into account quantities of such products (primarily, dairy ones) recommended for consumption by sensitive population groups (first of all, pregnant and breast-feeding women).

The outlined experience accumulated in health risk assessment when giving grounds for hygienic criteria of food products safety in the EAEU and Russia can be useful for improvement and international harmonization of risk assessment. It is advisable to consider such basic aspects in the process as possible convergence of scientific approaches to assessing consumer health risks when substantiating hygienic standards, harmonization of risk assessment tools, exchange of experience and a constructive international discussion on practices related to substantiation of hygienic standards.

Key words: health risk assessment, hygienic standards, food products, hazard factors, level of exposure, international harmonization of risk assessment.

The Russian Federation accession to the World Trade Organization, collaboration in the Customs Union within the framework of the Eurasian Economic Community, makes sanitary legislation convergence and, in particular, harmonization of sanitary and hygienic standards of product quality in line with international standards, to be one of the highest priorities.

To date, application of the methodology for analyzing health risks while ensuring product safety is enshrined in international legal acts and national legislation of Russian Federation. Currently, the development of regulatory standards for the quality of environmental objects necessarily requires methodology for assessing risk to public health.

In the Russian Federation, first of all, they include the Federal Law "On Technical Regulation"1 No. 184-FZ, Federal Law "On Sanitary and Epidemiological Welfare of the Population" No. 52-FZ. The Russian Federation laws, as well as international documents, interpret product

(C) Shur P.Z., Zaitseva N.V., 2018

Pavel Z. Shur - Doctor of Medicine, Academic Secretary (e-mail: shur@fcrisk.ru; tel.: +7 (342) 238-33-37; ORCID: https://orcid.org/0000-0003-2356-1145).

Nina V. Zaitseva - Academician of the Russian Academy of Sciences, Doctor of Medical Sciences, Professor, Scientific Director (e-mail: znv@fcrisk.ru; tel.: +7 (342) 237-25-34; ORCID: https://orcid.org/0000-0001-5171-3105).

${ }^{1}$ On Technical Regulation (last edited on July 29, 2017): The RF federal law issued on December 27, 2002 No.184-FZ [Web-source] // KODEKS: an electronic fund of legal and reference documentation.. - URL: http://docs.cntd.ru/document/901836556 (date of visit April 22, 2017).

${ }^{2}$ On Sanitary and Epidemiologic Welfare of the Population: The RF Federal Law issued on March 30, 1999 No. 52-FL [websource] // KonsultantPlus. - URL: http://www.consultant.ru/document/cons_doc_LAW_22481/ (date of visit April 22, 2017). 
safety as the absence of unacceptable risk to consumer life and health. This is the legal basis for applying the methodology in developing hygienic standards that ensure food safety for health in Russia, and the Eurasian Economic Union.

Food products safety in Russia and the EAEU is ensured by the establishment of mandatory requirements within the framework of the Customs Union Technical Regulations. However, in the transitional period, when the complete package of technical regulations has not been finally formed, in the absence of a standard, the Unified Sanitary-Epidemiological and Hygienic Requirements for Goods subject to Sanitary and Epidemiological Surveillance (Control) shall be applied in the system of technical regulation. Hygienic standards are an integral part of technical regulations. In the field of food-stock and foodstuffs safety in Russian Federation and in the territory of the Customs Union, more than 7,000 sanitary and epidemiological indicators are monitored, 3 thousand of which were harmonized in the preparation of the regulatory system of the Customs Union Agreement on Sanitary Measures.

At the same time, it is necessary to emphasize that Russian Federation, as a member of the WTO, retained the right to establish more stringent requirements than the international ones, if needed in view of the protection level established on its territory, provided there's a competent scientific rationale developed on the basis of the risk assessment system.

It should be noted that, both in the system of technical regulation and in the Unified Sanitary and Epidemiological Requirements, hygienic standards established in the framework of the hygienic rationing concept according to "zero" risk criteria are used as indicators of food safety. These hygienic standards need to be acknowledged based on the concept of tolerable (acceptable) level of risk and, in some cases, also to be revised. Justification of hygienic standards for the quality of food products on the basis of health risk criteria is one of the key elements in harmonization with the standards adopted in global practice.

For this purpose, the basic principles for validating the risk-based standards in Russia are harmonized with international practice, primarily with the guidelines of Codex Alimentarius Com- mission [1]. They include the priority of safety, concept of non-zero risk, phasing of the procedure, preference for quantitative assessments, priority to epidemiological studies, and others.

In accordance with these principles, by now, the standards for a number of food safety hazards have already been substantiated by health risk criteria in the EAEU. First of all, they include pesticides, nitrates, tetracyclines residuals, ractopamine, and tolerable content of Listeria.

However, this is just the beginning of a big job. To systematically implement it, food priority items, such as bakery, confectionery, vegetable oil, milk, meat products, etc., were identified using the production and consumption criteria. Priority pollutants of food products were identified. These include metals, mycotoxins, antibiotics and a number of organic compounds. As one of the identification criteria, we consider the absence of a harmonized approach to justification of the existing standards.

Methodical approaches to risk assessment for the tasks of validating the hygienic standards are basically identical to the general practice of food safety health risk assessment.

In line with the phasing approach to health risk assessment procedure, the development of quality standards using risk criteria includes phases of hazard identification, exposureresponse assessment, exposure assessment and risk profile. However, to solve the problems of validating the hygienic standards, these phases are defined by a number of features.

So, when defining a hazard, no hazard factors are being identified, since a certain factor is already under regulation. The major focus is made to the in-depth analysis of the information available on its features, sources and actual content levels in products, to studying hygienic norms and standards in global practice. The framework to form probable effects of exposure and identification of the most sensitive contingents, including the individual sensitivity markers being applied, is also subject to evaluation.

Based on hazard identification, a decision is made about the need for and the possibility for further procedure to justify risk-based standards.

The peculiarities of exposure-response assessment phase for chemical factors, and characteristics of hazard for microbiological factors, is the establishment of no observed effect levels 
and/or threshold exposure levels in laboratory and epidemiological studies. As the no observed effect levels, the values characterizing the absence of an adverse effect (NOAEL) are most often considered. When validating hygienic standards according to the findings of epidemiological studies, reference levels of exposure (BMD, BMC) are often used.

An important component in the "exposureeffect (response)" assessment phase is the analysis and, if necessary, mathematical models that describe quantitatively the dependences of the adverse effect probability on the level of exposure. At this stage, the parameters of health risk evolution models, recommended by the Eurasian Economic Commission as a tool for risk assessment of products, including food, can be justified.

When validating hygienic standards in the exposure assessment phase, the scenarios are formed, which foresee the maximum possible, standard, and actual level of exposure. In scenarios that provide standard and actual level of exposure, it is advisable to consider the exposure profile for the most sensitive population groups. The exposure assessment for the tasks of validating hygienic standards by health risk criteria is done indirectly and directly, and the methods addressed to examining the exposure markers are very much in demand.

The risk profile is developed step-by-step for the scenarios considered at the stage of exposure assessment using the parameters and models chosen in the "exposure-effect (response)" assessment. In the event, if the maximum possible exposure level does not lead to unacceptable health risk, the remaining scenarios need not be considered. Through risk profiling phase, we establish the levels of risk factors in environmental objects or products that provide the maximum exposure that determines tolerable (acceptable) level of health risk. These values are considered risk-based standards.

In the course of profiling risk, for the tasks of justifying hygienic standards, there are some relevant aspects of this process as follows:

- Assessment of the threshold (reference) levels uncertainty and identification of the modifying factors;

- Assessment of the adverse effects severity;

- Identifying levels of tolerable (acceptable) level of health risk.
To ensure that a hygienic standard reliably provides the level of risk not higher than the tolerable, based on the uncertainty analysis of risk assessment, there are safety factors/modifying factors established, upon which the threshold or no observed effect levels are reviewed. For example, when using findings of the epidemiological study made for the most sensitive recipients groups, the modifying factors can be equal to 1 .

An important issue in establishing riskbased standards is the identification of the tolerable (acceptable) level of risk. Today, in Russia it is customary to consider the value of $1 \cdot 10^{-4}$ as an acceptable level of health risk. This level characterizes lifelong risk of death or disease with a severity close to unity.

Assessing the severity of various effects (responses) has an essential role in the quantitative assessment of risk, and may affect the value of hygienic standards validated by risk criteria. The value characterizing the severity effect of 0 - absolute health, up to 1 - death is determined also on the basis of the expert assessments, including the standardized scales for disease severity applied. For example, when calculating DALY index used by the World Health Organization (WHO) to estimate harm due to diseases, a severity index standardized relative to the state of death is used.

A quantitative assessment of health risk, taking into account the severity of the probable responses, showed that consumption of food products containing residual tetracyclines at a level of $10 \mu \mathrm{g} / \mathrm{kg}$ and higher could lead to unacceptable risk to the health of children population. The standards for the tolerable levels of tetracycline - the acceptable daily intakes (ADI), and the maximum residues level in food (MRL) were recorded in 1990 in the thirty-sixth report of the Joint FAO/WHO Expert Committee on Food Additives (JECFA) [2].

The no-observed effect level (NOEL) of tetracycline is set at $2 \mathrm{mg}$ per day. The study results of tetracycline effects on humans served as the basis here. As a critical effect, we considered the impact on intestinal microflora (increased coliform resistance). With the establishment of an acceptable daily intake ( $3 \mu \mathrm{g}$ per kg of body weight, per day), the uncertainty factor of 10 was taken, due to variability of intestinal flora in humans. 


$$
A D I=\frac{M_{50}(\mu g / g) \times \text { IntestinesContentMass }(220 \mathrm{~g})}{\text { Bio-availablePeroralDose } \times \text { StockFactor } \times \text { IndividualBodyMass }(60 \mathrm{~kg})}
$$

In the fortieth report of the Joint FAO/WHO Expert Committee on Food Additives, the acceptable daily intake of tetracyclines was reconsidered [3]. On the basis of the Committee's conclusion that the variability is small among individuals and the uncertainty factor is no longer appropriate, it is therefore advisable to take $30 \mu \mathrm{g}$ per $\mathrm{kg}$ of body weight per day as an acceptable daily dose. To quantify the risk, we calculated tolerable daily doses for tetracycline and oxytetracycline for different types of microorganisms by the formula (1) recommended by FAO/WHO [4].

The formula was developed based on $\mathrm{MIC}_{50}$ modal value $\left(\mathrm{MIC}_{50}\right.$ is the minimum antibiotic concentration that inhibits growth of $50 \%$ of cultures of a particular microorganism), the safety factor to consider different types of variability, the intestinal contents, the weight of an individual, and the bioavailability of the antibiotic oral dose. $\mathrm{MIC}_{50}$ values of tetracycline and oxytetracycline for 10 different microorganisms were taken in accordance with the WHO Food Additives Series 36, with safety factor value of 1 , the proportion of tetracyclines bioavailable oral dose of 0.6 , the mass of intestinal contents of $220 \mathrm{~g}$, the average mass of an individual $-60 \mathrm{~kg}$.

The acceptable daily intakes for 10 different types of microorganisms obtained in the calculation, by the formula (1), varied from $0.37 \mu \mathrm{g} / \mathrm{kg}$ body weight relative to Clostridium spp. up to $195.6 \mu \mathrm{g} / \mathrm{kg}$ body weight for Escherichia coli and Proteus spp. (Table 1); such a high variability in the results may indicate the need to include an additional uncertainty factor in the calculation of a tolerable daily dose, especially for the most sensitive population groups, for example children, to carry out health risk assessment, taking into account the parameters of these groups.

Table 1

Examples of acceptable daily intakes of variable microorganisms

\begin{tabular}{|l|c|}
\hline \multicolumn{1}{|c|}{ Microorganism } & $\begin{array}{c}\text { Acceptable Daily } \\
\text { Intake, } \mu \mathrm{g} / \mathrm{kg}\end{array}$ \\
\hline Escherichia coli & 195.56 \\
\hline Bifidobacterium spp. & 97.78 \\
\hline Bacteroides fragilis & 24.44 \\
\hline Eubacterium spp. & 12.22 \\
\hline Clostridium spp. & 0.38 \\
\hline Streptococcus spp. & 97.78 \\
\hline Fusobacterium spp. & 0.76 \\
\hline Lactobacillus spp. & 12.22 \\
\hline Proteus spp. & 195.56 \\
\hline Peptostreptococcus spp. & 12.22 \\
\hline
\end{tabular}

The formation of an imbalance in intestinal microbial flora, according to in vitro studies, can be illustrated by the results of mathematical modeling of facultative microflora growth against the background of obligate flora suppression $^{3}$, primarily of Bifidobacterium.

Scientific studies devoted to pathogenetic processes in the intestine ${ }^{4}[2-8]$ present materials on the occurrence of microorganisms imbalance of varying degree for various diseases (Table 2, 3) [5].

According to the studies' results in the whole population, these diseases are associated with a change in the microflora of the first class: from 18.6 to $34.8 \%$, the second: from 24.2 to $45.7 \%$, the third: from 27.0 to $56.3 \%$. In the children's population, there is also an imbalance of the intestinal microflora in these diseases: of the first class: from 2.0 to $74.0 \%$, the second class: from 26.0 to $84.0 \%$ and the third: from 0.0 to $39.1 \%$.

\footnotetext{
${ }^{3}$ Petrenko V.V. Clinical and pathogenetic peculiarities and ways to treat dysbacteriosis in the intestines and dislipidemia in patients with functional constipation: thesis of the dissertation for candidate of medical sciences degree. - Saint Petersburg, 2009. - 122 p. Gusakova E.V. Interference currents applied in complex sanatorium-resort treatment of patients with irritable bowels syndrome: thesis of the dissertation for candidate of medical sciences degree. - Moscow, 2003. - $121 \mathrm{p}$.

Orlova N.A. Dysbiosis and possible ways to treat it in patients with inflammatory intestines diseases with combined pathologies and/or symptoms beyond the intestines: thesis of the dissertation for candidate of medical sciences degree. - Saint Petersburg, 2010. - $130 \mathrm{p}$.

${ }^{4}$ Ivanova T.N. Microbiological peculiarities of dysbiosis in people living in the polar regions: thesis of the dissertation for candidate of medical sciences degree. - Saint Petersburg, 2008. - 159 p.
} 
Table 2

Occurrence of intestinal microflora microorganisms imbalance in various diseases (adults), $\%$

\begin{tabular}{|l|c|c|c|c|}
\hline \multicolumn{1}{|c|}{ Group (code ICD10) } & Absence & $\begin{array}{c}1 \text { class } \\
\text { severity }\end{array}$ & $\begin{array}{c}2 \text { class } \\
\text { severity }\end{array}$ & $\begin{array}{c}3 \text { class } \\
\text { severity }\end{array}$ \\
\hline IBS with diarrhea (K58.0) & 0 & 37.8 & 35.1 & 27.0 \\
\hline IBS without diarrhea (K58.9) & 0 & 18.6 & 45.8 & 35.6 \\
\hline Constipation (K59.0) & 0 & 21.2 & 24.2 & 54.5 \\
\hline Inflammatory bowel disorder (K50-K51) & 0 & 0.00 & 43.7 & 56.3 \\
\hline
\end{tabular}

Table 3

Occurrence of intestinal microflora microorganisms imbalance in various diseases (children)

\begin{tabular}{|l|c|c|c|c|}
\hline \multirow{2}{*}{ Group (code ICD10) } & \multicolumn{4}{c|}{ Imbalance, \% } \\
\cline { 2 - 5 } & $\begin{array}{c}\text { No } \\
\text { disorders }\end{array}$ & $\begin{array}{c}\text { 1class } \\
\text { severity }\end{array}$ & $\begin{array}{c}2 \text { class } \\
\text { severity }\end{array}$ & $\begin{array}{c}3 \text { class } \\
\text { severity }\end{array}$ \\
\hline IBS with diarrhea (K58.0) & 0 & 22.2 & 66.7 & 11.1 \\
\hline Constipation (K59.0) & 0 & 74.0 & 26.0 & 0 \\
\hline Functional bowel disorder, unspecified (K59.9) & 0 & 15.0 & 84.0 & 1.0 \\
\hline Iron deficiency anemia (D50) & 0 & 39.8 & 46.6 & 13.6 \\
\hline Other atopic dermatitis (L20.8) & 0 & 40.6 & 37.2 & 22.2 \\
\hline Duodenitis (K29.8, K29.9) & 26.7 & 31.5 & 33.7 & 8.1 \\
\hline Food allergies (T78.0, T78.1, T78.4) & 1.4 & 12.6 & 46.9 & 39.1 \\
\hline General variable immunodeficiency, unspecified (D83.9) & 0 & 2.0 & 80.0 & 18.0 \\
\hline
\end{tabular}

Based on the average daily intakes of animal origin food products in Europe and daily intakes of animal origin food for the adult population in Russian Federation, as well as the values of tetracycline maximum residual levels (MRL) recommended by the WHO (1990), FAO/WHO (1998) adopted in the USA, and the maximum tolerable levels in the Customs Union, the maximum daily intake of tetracycline with food was established for 10 exposure scenarios.

Modeling the imbalance in the intestine microflora upon calculation of the values for the maximum daily intake and tetracycline concentration in the gastrointestinal tract for the exposure scenarios studied made it possible to establish that the scenarios harmlessness to health (the content of facultative microorganisms does not exceed $5 \%$ of the total number of bacteria) were the ones, which assumed the intake of tetracyclines residual amounts not exceeding $10 \mu \mathrm{g} / \mathrm{kg}$ per day.

The risk contingent, people with tetracycline-sensitive intestinal microflora, account for up to $70 \%$ of the population [6]. With this in mind, the consumption of food products containing tetracyclines may increase the risk of a number digestive system disorders
(K58.0, K58.9, K59.0, K50-K51) in the population of Russia by $23 \%$ of cases, if the balance of the intestinal microflora is disturbed. As the reference most sensitive population for the quantitative health risk assessment, children aged 1-11 years were considered. Assessing the risk of developing an intestinal microflora imbalance and further increase in the risk of associated diseases in children, considering the exposure peculiarities for this group, showed that the risk of developing an intestinal microflora imbalance under tetracyclines effect for this group was absent only when consuming food with residual amounts of antibiotics in food products at a level not higher than $10 \mu \mathrm{g} / \mathrm{kg}$.

If there is an imbalance of intestinal microflora in children, including those caused by residual tetracycline concentrations in food products of more than $10 \mu \mathrm{g} / \mathrm{kg}$, the risk of digestive system disorders increases to 0.000461 , of dermatitis - to 0.000725 , food allergy - to 0.000149 , of blood diseases - up to 0.001372 . An increase in the risk of digestive system sick rate in children's population in Russian Federation can be up to $4 \%$ of cases, blood diseases up to $8 \%$ of cases, skin diseases - up to $0.9 \%$ of cases, allergies - up to $0.1 \%$ of cases. 
With the quantitative assessment of microbiological risk applied, taking into account its severity showed that the standards for Listerium content in a number of the EAEU food products ensure safety of consumers' health in contrast to the norms recommended by the Codex Alimentarius Commission for products in trade.

Listeriosis, caused by L. Monocytogenes intake with food, is relatively rare, but a serious disease affecting mainly sensitive population groups. The infection source and route is usually unknown, but the food contaminated with L. Monocytogenes is considered the main path of infection and the cause of $99 \%$ of Listeriosis cases [7].

According to the Centers for Disease Control and Prevention, in 2000, L. Monocytogenes ranked second in terms of mortality (21\%) among all the foodborne infections pathogens under monitoring by the organization, and the number one in the rate of hospitalization $(90.5 \%)$. The mortality in cases of invasive listeriosis among the hospitalized patients was $20-30 \%[8,9]$.

The most frequent sources of Listeriosis outbreaks are various kinds of soft cheeses, processed meat, salami, pasteurized milk, unpasteurized milk, raw vegetables, etc. [10].

In accordance with the requirements of the Customs Union Technical Regulations and the Unified Sanitary Requirements, L. Monocytogenes content in $25 \mathrm{~g}$ of product is not allowed, which corresponds to a tolerable level of bacteria content of L. Monocytogenes $/ \mathrm{g}$ $0.04 \mathrm{CFU}$ for all product groups under study.

The primary document of Codex Alimentarius that contains requirements for tolerable levels of L. Monocytogenes in food is CAC/GL61-2007 [11]. In accordance with CAC/GL61-2007, the criterion value for the allowable content of L. Monocytogenes in food products is chosen based on the probability of growth and reproduction of bacteria in the product group under study. Thus, for food products that do not support growth and reproduction of L.Monocytogenes due to their physicochemical properties, an acceptable level of bacteria in $100 \mathrm{CFU}$ of L. Monocytogenes/g is established, and for food products in which growth and reproduction of L. Monocytogenes is possible $-0.04 \mathrm{CFU}$ of L. Monocytogenes/g. The content of L.Monocytogenes in fish, fruit and vegetable products is standardized by CAC/GL 21-1997 [12] in accordance with the established requirements for the production, and using the HACCP system.

In the European Union countries, in accordance with EU Regulation 1441/2007 [17], the criteria for L.Monocytogenes content for infant formula and therapeutic food products (0.04 CFU L. Monocytogenes/g) are established, for other foods, in which L. Monocytogenes growth and reproduction are possible (100 CFU L.Monocytogenes/g in market circulation, $0.04 \mathrm{CFU}$ L.Monocytogenes/g before being released to the market by the manufacturer), as well as for other products that do not support L.Monocytogenes growth and reproduction (100 CFU L.Monocytogenes/g).

To assess population health risks associated with the intake of L.Monocytogenes with food products, dose-response models were used. In this context, the dose is understood as the amount of microorganisms coming through gastrointestinal tract. An adverse health effect was considered as the probability of infection, development of a disease or onset of death. Such models, as a rule, are constructed using the known statistical functions of probability distribution, the dependencies ratios are determined from the findings of epidemiological studies. It should be noted that in the models considered, dose-response dependencies are described at the population level, the disease probability at the level of an individual is not estimated. In assessing risk, attention should be paid to the characteristics of the population being studied, in particular, to the immune status.

One of the simplest and most frequently used models is an exponential model with one parameter $[14,15]$ :

$$
P_{i}=1-\exp \left[-r_{i} \cdot N_{i}\right],
$$

where $P_{i}$ is a disease probability after intake of $i$-th product, $N_{i}$ is a consumed dose of microorganisms, $r_{i}$ - parameter corresponding to a disease probability when exposed to a single microorganism.

Equation (2) is widely used to assess the likelihood of diseases caused by the action of 
Listeria Monocytogenes [16]. In calculating the risk of disease in people with normal immunity, the known coefficients were used for three types of products:

1. Smoked fish: $r_{1}=5.6 \cdot 10^{-10}[22]$;

2. Chocolate milk: $r_{2}=5.8 \cdot 10^{-12}[21]$.

3. Tuna-corn salad (vegetables): $r_{3}=1.8 \cdot 10^{-8}[16]$.

The daily dose of microorganisms was calculated at the exposure assessment phase.

When assessing risk of a disease after consuming several types of products, we used the probability summation hypothesis: $P=\sum_{i} P_{i}$, which is valid for small values of $P_{i}$.

To calculate the probability of a disease in people of the sensitive group, a coefficient $r=3.15 \cdot 10^{-7}$ was used.
The exposure assessment was based on the average daily intake of food groups considered to be the most probable sources of L. Monocytogenes [18] by different population groups and the tolerable content of L. Monocytogenes in food. For the Russian Federation population, several options were considered for daily intakes by the adult population, including pregnant and lactating women of the following food categories: vegetables, fruits, fat products, dairy products, meat products, fish (seafood) used to assess the exposure to L. Monocytogenes [17]. Pregnant and lactating women were considered as the population sensitive groups. The exposure scenarios characteristics are presented in Table 4.

The maximum daily intake of L. Monocytogenes with food products, taking into account the optimal average daily intake of food for pregnant and lactating women, is shown in Table 5.

Table 4

Characteristics of exposure scenarios

\begin{tabular}{|c|l|c|}
\hline Scenario & \multicolumn{1}{|c|}{ Set of Food Products } & $\begin{array}{c}\text { Tolerable content } \\
\text { of L. Monocytogenes } \\
\text { in a food product, } \\
\text { CFU/g }\end{array}$ \\
\hline 1 & Recommended daily intake of food products in Russian Federation & $0.04^{* *}$ \\
\hline 2 & Recommended daily intake of food products in Russian Federation & 100 \\
\hline 3 & $\begin{array}{l}\text { Actual daily intake of food products by the adult population in Rus- } \\
\text { sian Federation }\end{array}$ & 0.04 \\
\hline 4 & $\begin{array}{l}\text { Actual daily intake of food products by the adult population in Rus- } \\
\text { sian Federation }\end{array}$ & 100 \\
\hline 5 & $\begin{array}{l}\text { Optimal average daily food intake for pregnant women, completed by } \\
\text { modeling results for Scenario 1 (vegetables and fish)* }\end{array}$ & 0.04 \\
\hline 6 & $\begin{array}{l}\text { Optimal average daily food intake for pregnant women, completed by } \\
\text { modeling results for Scenario 2 (vegetables and fish)* }\end{array}$ & 100 \\
\hline 7 & $\begin{array}{l}\text { Optimal average daily food intake for pregnant women, completed by } \\
\text { modeling results for Scenario 3 (vegetables and fish)* }\end{array}$ & 0.04 \\
\hline 8 & $\begin{array}{l}\text { Optimal average daily food intake for pregnant women, completed by } \\
\text { modeling results for Scenario 4 (vegetables and fish)* }\end{array}$ & 100 \\
\hline 9 & $\begin{array}{l}\text { Optimal average daily food intake for lactating women, completed by } \\
\text { modeling results for Scenario 1 (vegetables and fish)* }\end{array}$ & 0.04 \\
\hline 10 & $\begin{array}{l}\text { Optimal average daily food intake for lactating women, completed by } \\
\text { modeling results for Scenario 2 (vegetables and fish)* }\end{array}$ & 100 \\
\hline 11 & $\begin{array}{l}\text { Optimal average daily food intake for lactating women, completed by } \\
\text { modeling results for Scenario 3 (vegetables and fish)* }\end{array}$ & 0.04 \\
\hline 12 & $\begin{array}{l}\text { Optimal average daily food intake for lactating women, completed by } \\
\text { modeling results for Scenario 4 (vegetables and fish)* }\end{array}$ \\
\hline
\end{tabular}


Table 5

The maximum daily intake of L.Monocytogenes with food products, taking into account the optimal average daily intake of food for pregnant and lactating women (g, gross), fully providing for their physiological needs for food substances and energy

\begin{tabular}{|c|c|c|c|c|}
\hline \multirow[b]{2}{*}{$\begin{array}{l}\text { Food products } \\
\text { group } \\
\text { Food products } \\
\text { group }\end{array}$} & \multicolumn{2}{|c|}{$\begin{array}{l}\text { L. Monocytogenes CFU } \\
\text { (tolerable content of L.Monocytogenes } \\
\text { in food product } 0.04 \mathrm{CFU} / \mathrm{g} \text { ) }\end{array}$} & \multicolumn{2}{|c|}{$\begin{array}{l}\text { L. Monocytogenes CFU } \\
\text { (tolerable content of L.Monocytogenes } \\
\text { in food product } 100100 \mathrm{CFU} / \mathrm{g} \text { ) }\end{array}$} \\
\hline & $\begin{array}{l}\text { L. Monocytogenes } \\
\text { CFU (tolerable } \\
\text { content of } \\
\text { L.Monocytogenes } \\
\text { in food product } \\
0.04 \text { CFU } / g \text { ) }\end{array}$ & $\begin{array}{l}\text { L. Monocytogenes } \\
\text { CFU (tolerable } \\
\text { content of } \\
\text { L.Monocytogenes } \\
\text { in food product } \\
100100 \mathrm{CFU} / \mathrm{g} \text { ) }\end{array}$ & $\begin{array}{l}\text { L. Monocytogenes } \\
\text { CFU (tolerable } \\
\text { content of } \\
\text { L.Monocytogenes } \\
\text { in food product } \\
0.04 \mathrm{CFU} / \mathrm{g} \text { ) }\end{array}$ & $\begin{array}{l}\text { L. Monocytogenes } \\
\text { CFU (tolerable } \\
\text { content of } \\
\text { L.Monocytogenes } \\
\text { in food product } \\
100 \mathrm{CFU} / \mathrm{g} \text { ) }\end{array}$ \\
\hline Vegetables & 20 & 5000 & 20 & 5000 \\
\hline Fruits & 12.8 & 3200 & 12.8 & 3200 \\
\hline Fat products & 2.48 & 6200 & 2.48 & 6200 \\
\hline Dairy & 23.6 & 5900 & 27.6 & 6900 \\
\hline Meat products & 6.8 & 1700 & 6.8 & 1700 \\
\hline Fish (seafood) & 2.8 & 700 & 2.8 & 700 \\
\hline
\end{tabular}

Table 6

Results of assessing Listeriosis probability

\begin{tabular}{|l|c|c|c|c|c|c|}
\hline Food products group & Scenario 1 & Scenario 2 & Scenario 3 & Scenario 4 & Scenario 5 & Scenario 6 \\
\hline Vegetables & $2.76 \mathrm{E}-07$ & $\mathbf{6 . 8 9 E}-04$ & $1.41 \mathrm{E}-07$ & $\mathbf{3 . 5 3 E - 0 4}$ & $2.76 \mathrm{E}-07$ & $\mathbf{6 . 8 9 E}-04$ \\
\hline Dairy & $2.16 \mathrm{E}-10$ & $5.40 \mathrm{E}-07$ & $1.29 \mathrm{E}-10$ & $3.22 \mathrm{E}-07$ & $7.43 \mathrm{E}-06$ & $\mathbf{1 . 8 6 E - 0 3}$ \\
\hline Meat products & - & - & - & - & - & - \\
\hline Fish & $1.35 \mathrm{E}-09$ & $3.37 \mathrm{E}-06$ & $5.38 \mathrm{E}-10$ & $1.34 \mathrm{E}-06$ & $1.35 \mathrm{E}-09$ & $3.37 \mathrm{E}-06$ \\
\hline Total & $2.77 \mathrm{E}-07$ & $\mathbf{6 . 9 3 E - 0 4}$ & $1.42 \mathrm{E}-07$ & $\mathbf{3 . 5 4 E - 0 4}$ & $7.71 \mathrm{E}-06$ & $\mathbf{2 . 5 5 E - 0 3}$ \\
\hline Food products group & Scenario 1 & Scenario 2 & Scenario 3 & Scenario 4 & Scenario 5 & Scenario 6 \\
\hline Vegetables & $1.41 \mathrm{E}-07$ & $\mathbf{3 . 5 3 E - 0 4}$ & $2.76 \mathrm{E}-07$ & $\mathbf{6 . 8 9 E - 0 4}$ & $1.41 \mathrm{E}-07$ & $\mathbf{3 . 5 3 E - 0 4}$ \\
\hline Dairy & $7.43 \mathrm{E}-06$ & $\mathbf{1 . 8 6 E - 0 3}$ & $8.69 \mathrm{E}-06$ & $\mathbf{2 . 1 7 E - 0 3}$ & $8.69 \mathrm{E}-06$ & $\mathbf{2 . 1 7 E - 0 3}$ \\
\hline Meat products & - & - & - & - & - & - \\
\hline Fish & - & - & - & - & - & $1.34 \mathrm{E}-06$ \\
\hline Total & $5.38 \mathrm{E}-10$ & $1.34 \mathrm{E}-06$ & $1.35 \mathrm{E}-09$ & $3.37 \mathrm{E}-06$ & $5.38 \mathrm{E}-10$ & $\mathbf{2 . 5 2 E - 0 3}$ \\
\hline
\end{tabular}

Based on the results of the dose-response modeling, the integrated probability of Listeriosis development was obtained for 12 exposure scenarios (Table 6).

Thus, for all exposure scenarios developed taking into account the maximum allowable content of L.Monocytogenes in a readyto-eat and marketed food product (L. Monocytogenes/g $100 \mathrm{CFU}$ ), the risk of Listeriosis is assessed as unacceptable to population.

In exposure scenarios using the allowable content of L. Monocytogenes at the end-point of food production (L.Monocytogenes/g 0.04 CFU), the risk level of health disorders associated with the intake of L.Monocytogenes with food is characterized as negligible (scenarios based on the optimal and actual daily consumption of food products by the Russian Federation population) and allowable (scenarios based on the optimal average daily set of food products for pregnant and lactating women).

In some cases, when validating hygiene standards, along with a quantitative assessment of the health risk, a quantitative estimate of the probable effect is used.

So, to solve the important task of validating the permissible levels of nitrate content in crop products used in the countries of the Customs Union, carcinogenic risk assessment was applied, taking into account the probable relationship between nitrate levels and the concentration of nitrosamines that are carcinogens in 
food products, as well as the probability of developing non-carcinogenic effects [19].

The most sensitive population group is children. This is due to a number of factors: a higher level of fluid intake per $\mathrm{kg}$ of body weight, an increased risk of developing intestinal infections, an increased hemoglobin susceptibility to oxidation compared with adults, an incompleteness of the gastrointestinal tract leading to an elevated $\mathrm{pH}$ in stomach, which in turn creates favorable environment for nitrate-reducing microflora and reduction of nitrates to nitrites; in addition, the presence of a less active methaemoglobinreductase in children of early age, in comparison with older children and adults, and hence its ability to metabolize excess methaemoglobin.

At the stage of assessing the dose-response relationship based on the published findings of the studies dedicated to nitrates action, we constructed exponential models for the dependence of non-carcinogenic (3) (methemoglobinemia) [20] and carcinogenic (4) [21] responses on the nitrates intake with food products of plant origin. When modeling the probability of methemoglobinemia occurrence, we took into account the conversion of $8 \%$ of nitrates, supplied with food products into nitrites.

$$
\begin{aligned}
& y=1-e^{0,000639 \cdot \mathrm{x}} \\
& y=1-e^{1,44 \mathrm{E}-07 \cdot \mathrm{x}}
\end{aligned}
$$

Where: $y$ is the percentage of methhemoglobin in blood (3), carcinogenic risk (4), and $x$ is the amount of nitrate ingested (mg/person/day).
The exposure was assessed on the basis of the recommended and actual average daily consumption of plant foods in Russian Federation and the acceptable levels of nitrates in them in the Customs Union countries. During exposition assessment, 5 scenarios were developed, taking into account the receipt of nitrates with vegetable origin food at the recommended intake level for vegetables and potatoes (maximum values within the range) (scenario 1), with an average actual level of consumption by the population aged 1 to 11 years (scenario 2), aged 11 to 18 (scenario 3), aged 18 to 60 (scenario 4), over the age of 60 (scenario 5), and the acceptable levels of nitrate content in vegetables and potatoes adopted in the countries of the Customs Union.

For the developed scenarios, the possible daily intake of nitrates with vegetables and potatoes, as well as doses of nitrates using standard mean body weight for children $(22.6 \mathrm{~kg})$, adolescents $(53 \mathrm{~kg})$ and adults $(60 \mathrm{~kg})$ was calculated. The obtained levels of possible daily intake of nitrates and the values of daily doses for nitrates supplied with products of plant origin for different scenarios are presented in Table 7.

Based on modeling the dose-response relationship, the probable levels of methaemoglobin were obtained for 5 levels of exposure being considered (Table 8 ).

Methaemoglobin levels for all the scenarios studied range from $0.24 \%$ (scenario 2 ) to $1.03 \%$ (scenario 1). Considering that the background level of methaemoglobin is from 1 to $3 \%$, and the health disorders are observed at the levels of higher than $10 \%$, the results of

Table 7

Levels of nitrates intake with crop products and the corresponding dose for different exposure scenarios

\begin{tabular}{|l|c|c|c|c|c|}
\hline & Scenario 1 & Scenario 2 & Scenario 3 & Scenario 4 & Scenario 5 \\
\hline Nitrate intake, $\mathrm{mg} /$ day & 202.2 & 47.9 & 70.5 & 87.5 & 84.0 \\
\hline Nitrates dose, $\mathrm{mg} / \mathrm{kg} /$ day & 3.4 & 2.1 & 1.3 & 1.5 & 1.4 \\
\hline
\end{tabular}

Table 8

Probable levels of methaemoglobin for various exposure conditions with nitrates

\begin{tabular}{|c|c|c|}
\hline Scenario & Nitrates intake with food of vegetable origin, $\mathrm{mg} /$ day & Methemoglobin level, \% \\
\hline Scenario 1 & 202.2 & 1.03 \\
\hline Scenario 2 & 47.9 & 0.24 \\
\hline Scenario 3 & 70.5 & 0.36 \\
\hline Scenario 4 & 87.5 & 0.45 \\
\hline Scenario 5 & 84.0 & 0.43 \\
\hline
\end{tabular}


health risk assessment for permissible nitrate levels in crop products showed that the predicted non-carcinogenic effect - methemoglobinemia ranged within the limits of the background level. This allows the conclusion that there is no unacceptable risk of developing non-carcinogenic effects (methemoglobinemia) associated with the intake of nitrates with plant origin foodstuffs.

The level of carcinogenic risk for all the investigated exposure scenarios is at the level of the maximum permissible $\left(1 \times 10^{-6}-1 \times 10^{-4}\right)$, with the maximum carcinogenic risk obtained for scenario 1, taking into account the recommended standards for the consumption of plant foods and tolerable values for the content of nitrates in these products $\left(2.92 \times 10^{-5}\right)$.

Within the framework of cooperation between the scientific institutions of Russia, Belarus and Kazakhstan the new approaches to risk assessment of products using modeling of health risk evolution were proposed [22].

When validating hygiene standards, the below approaches allow:

- to predict evolution of the health risk during the period of consumer contact with products;

- to calculate risk level for different groups of consumers, including the sensitive;

- to model health risks according to the specified exposure scenarios

The evolutionary model of health risk accumulation (evolution of disorders risk in organs and body systems functions), when using products (goods), is a mathematical description of the consumers health status changes under the exposure to harmful factors' complex typical of products (goods) with a long time. Evolution of disorders risk in organs and body systems functions is caused by mechanisms of two types: natural abnormalities associated with cells damage in organs, and risk increment due to non-standardized effect of factors common for products (goods).

The evolutionary model for accumulation of risk to consumer health from products (goods) is constructed on the basis of paired dependences that reflect influence of factors inherent in products (goods) on the state of human health and shown forth in scientific publications. Pair dependencies are included in the evolutionary model of accumulating risk to consumers' health of products (goods) using the algorithms for their adaptation to computational forms.

The computational form for evolutionary model is the system of recurrence relations recorded for each type of response (health disorder). The general form of the recurrence relations is given by the expression (5) [23-25]:

$$
R_{t+1}^{i}=R_{t}^{i}+\left(\alpha_{i} R_{t}^{i}+\sum_{j} \Delta R_{t}^{i j}\right) C,
$$

Where:

$R_{t+1}^{i}$ is a risk of health disorders by the $i$ th respond at a time $t+1$;

$R_{t}^{i}$ is a risk of health disorders by the $i-t h$ respond at a time $t$;

$\alpha_{i}$ is a coefficient that takes into account the evolution of risk due to natural causes;

$\Delta R_{t}^{i j}$ is increment of health disorders risk by the $i$-th response, due to the $j$-th factor for 1 year from the time $t$;

$C$ is a time empirical coefficient.

Empirical coefficient of time allows for execution of calculations with a time step of less than 1 year. The coefficient' values per different time steps are shown in Table 9.

Table 9

The value of time empirical coefficient (C), depending on the time step

\begin{tabular}{|c|c|c|c|c|c|}
\hline $\begin{array}{c}\text { Time } \\
\text { step, } t\end{array}$ & 1 hour & 1 day & 1 week & 1 moth & 1 year \\
\hline$C$ & 0.000114 & 0.00274 & 0.019231 & 0.083333 & 1 \\
\hline
\end{tabular}

In evolutionary modeling, we consider:

- risk of non-infectious non-carcinogenic impairment of body organs and systems functions under exposure to chemical agents (noncarcinogenic substances);

- risk of carcinogenic effects (malignant neoplasms) caused by exposure to chemical agents (carcinogens);

- risk of infectious and parasitic diseases when exposed to biological agents.

Increment of health disorders risk due to the factors typical of products (goods) is determined on the basis of paired dependences (6):

$$
\Delta R_{t}^{i j}=\beta_{i j} f^{i j}\left(X_{t}^{j}\right),
$$


Where:

$\Delta R_{t}^{i j}$ is increment of health disorders risk by the $i$-th response, due to the $j$-factor during 1 year from the time $t$;

$\beta_{i j}$ is a coefficient that reflects the influence of the $j$-th factor common for products (goods) on the rate of accumulating the risk of the $i$-th effect (response);

$f^{i j}\left(X_{t}^{j}\right)$ is a function that reflects the relationship between the $j$-th factor exposure and the risk of health disorders by the $i$-th effect (response);

$X_{t}^{j}$ is exposure of the $j$-th factor at a time $t$.

The particular form of $f^{i j}\left(X_{t}^{j}\right)$ function and the values of $\beta_{i j}$ coefficients may be different for each pair "factor - effect (response)" in view of different mechanisms of the factors and methods for constructing models.

Coefficients that take into account risk evolution due to natural causes $\left(\alpha_{i}\right)$ are determined based on the background morbidity and mortality rates for the diseases classes (in the case of non-carcinogenic risk) and the specific ICDs (in the assessment of carcinogenic effects risk), reflecting the functional impairment of critical organs and systems.

When choosing the no observed exposure levels for chemical risk factors of products (goods), there are some peculiarities as follows:

- in establishing the no observed level, focus to the critical effects (critical organs/system), which arise at the lowest exposure level (for non-carcinogenic action);

- establishing the no observed level for different time characteristics of the exposure (acute, chronic);

- absence of the no observed level for carcinogenic effects of chemicals with a genotoxic mechanism.

The characteristics (parameters) of the dose-response relationship are:

- version of the dependence that reflects an increase in the probability of developing a dangerous reaction with increasing the dose (concentration) by $1 \mathrm{mg} / \mathrm{kg}$, or $1 \mathrm{mg} / \mathrm{m}^{3}\left(\mathrm{SF}_{\mathrm{i}}\right.$, $\mathrm{SF}_{\mathrm{o}}, \mathrm{SF}_{\mathrm{d}}, \mathrm{UR}$ );

- level of exposure associated with a certain probability of the effect;
- safe level of exposure (for non-carcinogens and carcinogens with a non-genotoxic mechanism).

When assessing microbiological risk, the "exposure-response" assessment is included into hazard characterization phase. The features of the "exposure-response" dependencies assessment for biological factors include:

- analysis of susceptibility of a risk contingent to the effects of biological hazards of products (goods);

- need to evaluate (using laboratory data) the sources and methods for preparing stuff containing pathogens;

- taking into account the variability and virulence of the pathogen during interaction with the susceptible organism and the environment;

- calculation of the biological agent effect probability to the people with different immunity levels;

- possibility to preserve microorganisms in the source, within transfer factors of the infection pathogen;

- using statistical models of dependence between the dose, virulence and manifestation (type, severity) of health responses in a susceptible population, taking into account pathways.

This approach was practiced to validate the hygienic standard for the content of ractopamine in meat products. In accordance with the decision of the Codex Alimentarius Commission, the maximum permissible levels of ractopamine in pork and beef were set at $0.01 \mathrm{mg} / \mathrm{kg}$, in liver: $0.04 \mathrm{mg} / \mathrm{kg}$, kidneys: $0.09 \mathrm{mg} / \mathrm{kg}$ [26].

At the same time, currently, ractopamine is banned for use in feed of farm animals in 80 countries of the world, including the European Union countries [27, 28], and authorized for use in pig breeding by 22 countries. Ractopamine is used in a number of countries as a feed additive, stimulating the build-up of muscle mass, reduction of fat mass and increasing the efficiency of using fodder for pigs, cattle, turkeys.

The Russian delegation position expressed at the $35^{\text {th }}$ session of the Codex Alimentarius Commission was that the permissible daily dose of ractopamine is insufficiently justified, and cannot be used to establish the 
maximum allowable levels of ractopamine in meat and by-products. The scientific basis for such position was the results of health risk assessment conducted by Rospotrebnadzor research organizations in collaboration with RAMS Research Institute of Nutrition.

Toxicological assessment of ractopamine in animal experiments did not allow for the unambiguous conclusions about the no observed levels. In experiments on mice, rats, dogs and monkeys, a number of dose-dependent effects were recorded at orally administered intakes of 2 to $568 \mu \mathrm{g} / \mathrm{kg}$ of body weight, including an increasing heart rate and heart left ventricle contractions amplitude, a decrease in both systolic and diastolic blood pressure. Several studies revealed that effects (e.g., bradycardia in dogs) were also observed with minimal exposure [27, 29].

In assessment of health risk associated with the receipt of ractopamine residual amounts with food recommended by the Codex Alimentarius Commission conducted in Russian Federation, the information on uterine leiomyoma development in an experiment was used as the initial data for the formation of exposure-effect model for calculating the carcinogenic risk level in mice [30]. It was determined that the carcinogenic risk would correspond to an acceptable level.

For non-carcinogenic effects, simulation of the exposure-effect dependence was carried out on based on the data provided by the European experts in the $\mathrm{FAO} / \mathrm{WHO}$ reports [31]. As a basic model, an evolutionary model of accumulating risk of cardiovascular system disorders was used, described in the methodological guidelines "Quantification of non-carcinogenic risk under exposure to chemicals based on the construction of evolutionary models. ${ }^{5}$.

In accordance with the mentioned document, a recurrence ratio of accumulating functional disorders risk for cardiovascular system is constructed in simulation by the formula 5 . In constructing a recurrence ratio of accumulating functional disorders risk for cardiovascular system under exposure to ractopamine from meat products, its toxicokinetics was taken into consideration (down-regulation in the body by $85 \%$ during the day [32]), and an increasing heart rate was considered as a marker effect.

This recurrence equation is the basis for constructing the evolution curve for the risk of cardiovascular system dysfunction under exposure to D-ractopamine dose (the calculated risk) and its associated curve without taking into account the effect of ractopamine $(\mathrm{D}=0)$ (the background risk).

An assessment of non-carcinogenic risk to health coming from food was made for two scenarios: the content of ractopamine in amounts recommended by the Codex Alimentarius Commission as an MRL and at the limit level for ractopamine quantitative determination in meat products.

As a result of modeling cardiovascular system dysfunctions, it was found that when implementing the first scenario (intake of foods containing ractopamine at the level of residues proposed by the Codex Alimentarius Commission) the risk of cardiovascular system dysfunctions would be 0.47 , which, according to MP 2.1.10.0062-12 , is classified as an unacceptable risk. In assessing risk in the second scenario (intake of ractopamine with food at the limit level for quantitative determination), the risk of cardiovascular system dysfunctions would be 0.141 , which, according to MP 2.1.10.0062-12, is also classified as unacceptable. This level of risk can also lead to a reduction in the life expectancy due to additional cases of cardiovascular system disorders (diseases characterized by high blood pressure, atherosclerotic heart disease).

As aforesaid, ADI value, adopted as the basis for establishing MRL for ractopamine ranges within $0-1 \mu \mathrm{g} / \mathrm{kg}$ of body weight, i.e. not authentically different from zero, and therefore cannot be used in practice, in particular, when determining the permissible residues of ractopamine in meat products.

The presented experience of health risk assessment in validating hygienic criteria for food safety in the EAEU and Russia can be

\footnotetext{
${ }^{5} \mathrm{MG}$ 2.1.10.0062-12. Qualification of non-carcinogenic risk under exposure to chemicals based on the construction of evolutionary models: Methodical guidelines. - M.: Rospotrebnadzor's Center for Hygiene and Epidemiology, 2012 - 36 c.
} 
useful for improvement and international harmonization of risk assessment. As the basic directions in this process, it is advisable to consider:

- convergence of scientific approaches to the assessment of risk to consumers health when validating the hygiene standards;

- harmonization of risk assessment tools;
- exchanging experience and constructive international discussion on the practice for validating the hygienic standards.

Funding. The research was not granted any sponsor support.

Conflict of interests. The authors state there is no any conflict of interests.

\section{References}

1. CAC/GL 62-2007 Working Principles for Risk Analysis for Food Safety for Application by Governments. Rome, 2007, 41 p.

2. Evaluation of certain veterinary drug residues in food. Thirty-sixth report of the Joint FAO/WHO Expert Committee on Food Additives. World Health Organ Tech Rep Ser., 1990, vol. 799, pp. 1-68.

3. Evaluation of certain veterinary drug residues in food: fiftieth report of the Joint FAO/WHO Expert Committee on Food Additives. Geneva, World Health Organization, 1999, 108 p.

4. Toxicological evaluation of certain veterinary drug residues in food. WHO Food Additives Series, 1996, № 38, nos 873-883 on INCHEM. Available at: http://www.who.int/foodsafety/publications/monographs/en/ (16.04.2017).

5. Zaitseva N.V., Shur P.Z., Aminov A.I., Kiryanov D.A., Kamaltdinov M.R. To estimate the additional risk of diseases of the gastrointestinal tract associated with dysbiosis of the intestinal microflora due to the impact of tetracycline residues in foods. Zdorov'e naseleniya i sreda obitaniya, 2012, no. 7, pp. 46-48 (in Russian).

6. Moubareck C., Gavini F., Vaugien L., Butel M.J., Doucet-Populaire F. Antimicrobial susceptibility of bifidobacteria. J Antimicrob Chemother, 2005, vol. 55, no. 1, pp. 38-44.

7. Foodborne listeriosis. Report of the WHO Working Group. Bulletin of the World Health Organization, 1988, vol. 66, no. 4, pp. 421-428.

8. Mead P.S., Slutsker L., Dietz V., McCraig L.F., Bresee S., Shapiro C., Griffin P.M., Tauxe R.V. Foodrelated illness and death in the United States. Emerging Infectious Diseases, 1999, vol. 5, no. 5, pp. 607-625.

9. CDC [U.S. Centers for Disease Control and Prevention]. 1998. 1997 Annual Report. CDC/USDA/FDA Foodborne Diseases Active Surveillance Network. CDC's Emerging Infections Program (Revised 14 March 2000). Available at: https://www.google.com/url?sa=t\&rct=j\&q=\&esrc= s\&source $=$ web\&cd $=1 \&$ cad $=$ rja\&uact $=8 \&$ ved $=2$ ahUKEwiYjJLAus7eAhWJDSwKHadkCMEQFjAAegQ ICRAC\&url=https \% 3A \% 2F \% 2Fwww2a.cdc.gov \% 2Fncid \% 2Ffoodnet \% 2Fsteering \% 2F $2004 \%$ 2Fjune \% 2FJune04 packet.pdf\&usg=AOvVaw0UNrRvIsjf23RQ3IeZZOUB (23.03.2017).

10. FDA/FSIS [U.S. Food and Drug Administration/Food Safety and Inspection Agency (USDA). 2001. Draft Assessment of the relative risk to public health from foodborne Listeria monocytogenes among selected categories of ready-to-eat foods. Center for Food Safety and Applied Nutrition (FDA) and Food Safety Inspection Service (USDA). Available at: https://www.foodsafety.gov/ dms/lmrisk.html (24.06.2013).

11. Guidelines On The Application Of General Principles Of Food Hygiene To The Control Of Listeria Monocytogenes In Foods. CAC/GL61-2007, 2007, 28 p. Available at: http://www.fao.org/input/download/standards/10740/CXG_061e.pdf(16.04.2017).

12. Principles and guidelines for the establishment and application of microbiological criteria related to foods. Codex Alimentarius Volume 1B General requirements (Food hygiene), 1997, 4 p.

13. Commission regulation (EC) No1441/2007 of 5 December 2007 amending Regulation (EC) No2073/2005 on microbiological criteria for foodstuffs. EUR-Lex. Available at: https:/eur-lex.europa.eu/eli/reg/2007/1441/oj (16.04.2017).

14. Haas C.N. Estimation of risk due to low doses of microorganisms: a comparison of alternative methodologies. American journal of epidemiology, 1983, vol. 118, pp. 573-582.

15. Rose J.B., Haas C.N., Regli S. Risk assessment and control of waterborne giardiasis. American journal of public health, 1991, vol. 81, pp. 709-713.

16. Risk assessment of Listeria monocytogenes in ready-to-eat foods: interpretative summary (Microbiological risk assessment series; no. 4). Geneva, World Health Organization, 2004, 81 p. 
17. Lindqvist R., Westöö A. Quantitative risk assessment for Listeria monocytogenes in smoked or gravad salmon/rainbow trout in Sweden. International Journal of Food Microbiology, 2000, vol. 58, pp. 181-196.

18. Rekomenduemye nabory produktov dlya pitaniya beremennykh zhenshchin, kormyashchikh materei i detei do 3-kh let (Razrabotany GU NII pitaniya PAMH) [Food products recommended for consumption by pregnant women, breast-feeding mothers, and children under 3 (Drawn up by Scientific Research Institute for Nutrition of the Russian Academy of Sciences)]. Registr. Available at: http://www.rlsnet.ru/articles_467.htm (16.04.2017) (in Russian).

19. Shur P.Z., Kiryanov D.A., Atiskova N.G., Chigvintsev V.M., Khrushcheva E.V. Justificaion of acceptable nitrate levels in crop product using health risk criteria. Zdorov'e naseleniya $i$ sreda obitaniya, 2013, vol. 248, no. 11, pp. 47-48 (in Russian).

20. Shuval H.I., Gruener N. Epidemiological and toxicological aspects of nitrates and nitrites in the environment. Am. J. Public Health, 1972, vol. 62, no. 8, pp. 1045-1052.

21. Ingested Nitrate and Nitrite and Cyanobacterial Peptide Toxins. International Agency for Research on Cancer (IARC), Monographs on the Evaluation of Carcinogenic Risks to Humans. Geneva, World Health Organization, 2010, vol. 94, 464 p.

22. Metodologiya otsenki riskov zdorov'yu naseleniya pri vozdeistvii khimicheskikh, fizicheskikh i biologicheskikh faktorov dlya opredeleniya pokazatelei bezopasnosti produktsii (tovarov) / Evraziiskaya ekonomicheskaya komissiya [Health risk assessment methodology under exposure to chemical, physical, and biological factors for determining criteria of products (goods) safety / The Eurasian Economic Commission]. Moscow, Yumanite Media, 2014, 115 p. (in Russian).

23. Kamaltdinov M.R., Kiryanov D.A. The application of recurrent relations for integrated health risk assessment. Zdorov'e sem'i - 21 vek, 2011, no. 3. Available at: http://www.fh-21.perm.ru/download/2011-3-6.pdf (16.04.2017) (in Russian).

24. Zaitseva N.V., Shur P.Z., May I.V., Kiryanov D.A. Approaches to the assessment of integrated health risk population based on evolution of mathematical models. Zdorov'e naseleniya i sreda obitaniya, 2011, no. 10, pp. 6-9 (in Russian).

25. Zaitseva N.V., Shur P.Z., Kiryanov D.A., Kamaltdinov M.R., Tsinker M.Yu. MEthodical approaches for health population risk estimation based evolution models. Zdorov'e naseleniya i sreda obitaniya, 2013, vol. 238, no. 1, pp. 4-6 (in Russian).

26. Residue evaluation of certain veterinary drugs. Joint FAO/WHO Expert Committee on Food Additives. Meeting 2010 - Evaluation of data on ractopamine residues in pig tissues. Available at: http://www.fao.org/docrep/012/i1618e/i1618e00.pdf(16.04.2017).

27. Scientific Opinion of the Panel on Additives and Products or Substances used in Animal Feed (FEEDAP) on a request from the European Commission on the safety evaluation of ractopamine. The EFSA Journal, 2009, vol. 1041, pp. 1-52.

28. Alemanno A., Capodieci G. Testing the Limits of Global Food Governance: The Case of Ractopamine. European Journal of Risk Regulation, 2012, vol. 3, 12 p.

29. Evaluation of certain veterinary drug residues in food. Sixty-second report of the Joint FAO/WHO Expert Committee on Food Additives. WHO technical report series 925. Rome, 2004. Available at: http://apps.who.int/iris/bitstream/handle/10665/43039/WHO_TRS_925.pdf?sequence=1 (16.04.2017).

30. Williams G.D. A Chronic Toxicity Study of Ractopamine Hydrochloride Administered Orally to Beagle Dogs for One Year. Unpublished report on study No. D05885 from Toxicology Division, Lilly Research Laboratories, Division of Eli Lilly and Company, Greenfield, IN, USA. Submitted to WHO by Elanco Animal Health, Division of Eli Lilly and Company, Indianapolis, IN, USA. June, 1987, 66 p.

31. WHO. Food additives series: 53 ractopamine (addendum) First draft prepared by Professor Fritz R. Ungemach. IPCS INCHEM. Available at: http://www.inchem.org/documents/jecfa/jecmono/v53je08.htm (16.04.2017).

32. Residues of Some Veterinary Drugs in Animals and Foods. FAO. Rome, 1993, 179 p.

Shur P.Z., Zaitseva N.V. Health risk assessment when giving grounds for hygienic criteria of food products safety. Health Risk Analysis, 2018, no. 4, pp. 43-56. DOI: 10.21668/health.risk/2018.4.05.eng

Received: 22.10 .2018

Accepted: 15.11 .2018

Published: 30.12.2018 


\title{
RISK ASSESSMENT PRACTICE IN HYGIENIC AND EPIDEMIOLOGICAL STUDIES
}

UDC 613.2

DOI: $10.21668 /$ health.risk/2018.4.06.eng

\section{NUTRITIONAL STATUS: THE TRENDS OF PRESCHOOL CHILDREN AGED 10-60 MONTHS IN THE NORTH OF VIETNAM}

\author{
Nguyen Thi Trung Thu ${ }^{1}$, Le Thi Thuy Dung ${ }^{2,3}$, Le Thi Tuyet ${ }^{1}$ \\ ${ }^{1}$ Hanoi National University of Education, Vietnam \\ 136 Xuan Thuy Str., Cau Giay District, Hanoi, 123106, Viet Nam \\ ${ }^{2}$ M.K. Ammosov North-Eastern Federal University, 58 Belinsky Str., Yakutsk, Republic of Sakha (Yakutia), \\ 677027, Russian Federation \\ ${ }^{3}$ Hanoi Medical University, 1 Ton That Tung Str., DongDa, Hanoi, 116001, Viet Nam
}

Health is the necessary foundation for the comprehensive development of children. Unhealthy nutritional status of children in all its forms is a global problem. Our research goal was to assess prevailing nutritional status and changes in it among pre-school children in the north of Vietnam. There were several stages in the examination, each performed once a quarter, from September 2017 to March 2018. The results showed that children's height and weight grew. At the initial stage of the examination average age of children was equal to 42 months, average weight and height were $14 \mathrm{~kg}$ and $95 \mathrm{~cm}$ respectively. At stage 2, average height and weight were equal to $14.2 \mathrm{~kg}$ and $97 \mathrm{~cm}$, and at stage 3 they were $15 \mathrm{~kg}$ and $99 \mathrm{~cm}$, respectively. All the applied models revealed the correlation between anthropometric indices of children aged 10-60 months and their age $(p<0.05)$, however, only the model $y$ $=0.2736 x+2.8943$ with $R^{2}=0.8571$ revealed a tight correlation between body mass index and age. We applied the WHO standards (2006) to assess the nutritional status of children. After 6 months of the examination we detected an increase in number of children with good nutritional status and a decrease in number of those with bad one that was the most tightly connected with malnutrition. At stage 3 we revealed $15.7 \%$ children with stunting, $4.3 \%$ children with underweight, and $3.3 \%$ with both disorders, among those who received insufficient nutrition. $1.5 \%$ children suffered from hypotrophy; and $0.1 \%$ children had underweight, stunting, and hypotrophy. Prevalence of overweight and obesity didn't decrease as at stage 1 overweight was detected in $4.5 \%$ cases, and obesity, in $1.2 \%$ cases; and at stage 3, they were detected in $5.5 \%$ and $1.1 \%$ cases respectively. Apart from that, in some cases malnutrition and disorders related to overweight occurred simultaneously: stunting and overweight in $0.6 \%$ cases, stunting and obesity, in $0.1 \%$ cases.

Key words: development of children, nutritional status, pre-school children, malnutrition, stunting, overweight, obesity.

\section{Introduction}

Health is the necessary foundation for the comprehensive development of children. Good health helps children not only to develop intelligence, raise the stature, increase mobility, learn and discover the world, but also to reduce the risk of illness and death. Therefore, regular nutritional assessment plays an important role in child care for family and school.
Nutritional status that doesn't conform to standards and can be determined as "unsatisfactory" or "unhealthy" in all its forms is a global health concern. Not only malnutrition (underweight, stunting, wasting and these disorders combined) but also over-nutrition (overweight and obesity) are reported to be serious problems affecting developing countries. Both of these conditions are hazardous for children as they cause greater risks of poor health and negative consequences for physical, cognitive, and be-

\footnotetext{
(C) Nguyen Thi Trung Thu, Le Thi Thuy Dung, Le Thi Tuyet, 2018

Nguyen Thi Trung Thu - PhD, Faculty of Biology (e-mail: trungthuhnue@gmail.com; tel. (+84) 983-42-09-85).

Le Thi Thuy Dung - Master of Science, Faculty of Pediatrics (e-mail: letono2002@gmail.com; tel: (+84) 987-00-89-14).

Le Thi Tuyet - PhD, Faculty of Biology (e-mail: lttuyet@gmail.com; tuyetlt@hnue.edu.vn; tel: (+84) 968-79 -55-55).
} 
havioral development among them than population in general $[1,2]$. Unhealthy nutritional status is a multi-factorial disease that is influenced by environmental and genetic factors, as well as the interaction between them [3, 4]. Malnutrition is one of the leading causes of morbidity and mortality among children under the age of five in developing countries [5].

Under-nutrition is the underlying cause of death in estimated $45 \%$ of all deaths among children aged under 5 years [5]. As per data provided by the $\mathrm{WHO}$, the number of children affected by stunting, underweight, and wasting globally was $37 \%, 15 \%$ and $8 \%$ respectively [6]. Under-nutrition is reported to be higher in Asia and Africa than in Europe; in Africa the prevalence of stunting and underweight has increased over the past 23 years [6].

According to the National Institute for Nutrition, in 2010 nutritional status among children under 5 years improved in Vietnam, but still unhealthy nutritional status prevalence remains at a high level. Vietnam has been one of these countries where malnutrition is an important public healthcare problem. The prevalence of underweight, stunting and wasting among preschool children were $17.5 \%, 29.3 \%$ and $7.1 \%$ at national level. The prevalence of over-nutrition among children under 5 years old is $5.6 \%$, of which the obesity prevalence is $2.8 \%$. In the urban areas the prevalence of over-nutrition is $6.5 \%$ [7].

Although, Vietnam has many programs to improve nutritional status at children, undernutrition is still a challenge for the public healthcare in the country.

The study therefore aimed to assess the prevalence of nutritional status among preschool children in the North of Vietnam, special attention being paid to occurrence of more than one nutritional status disorder. In addition, the aim was to evaluate the changes in nutritional status among children each 3 months.

\section{Data and methods}

\subsection{Data collection}

A longitudinal study was conducted in 8 preschools in Hanoi city, Nam Dinh prov- ince, Thanh Hoa province. 2,035 children aged 10-60 months were selected randomly excluding children who had any medical causes for malnutrition, overweight or obesity such as disorders (hypothyroidism and Cushing syndrome) or drugs (steroids, antidepressants, antipsychotics, and seizure medications). The study was conducted during 6 months from September 2017 to March 2018.

Sample size for cross-sectional study was calculated as per the following formula [8]:

$$
N=\frac{Z_{1-\alpha / 2}^{2} \times p \times(1-p)}{d^{2}} \times D E
$$

where $p$ (risk factor ratio in the study population) was estimated at $10 \%, d$ (maximum error of estimation) was 0.02 with reliability of $98 \%$, DE (design factor) was 2 , $\mathrm{Z}_{(1-\alpha) / 2}$ (coefficient of confidence) was 1.96 with $\alpha=0.05$. With an additional $10 \%$ nonresponse in the formula, the sample size needed for the study was 1,989 children.

In fact, the study was to be conducted on 2,287 preschool children. We excluded children with lacking information (birth date, weight, height, sex), children aged over 60 months, and children who were absent on the day of measurement; thus, the total sample size dropped to 2,035 children, and it was slightly larger than expected sample size. Our study was approved by The Ethics Committee of the Vietnam National Institute for Nutrition.

\subsection{Measurements}

Data about name, date of birth, sex of the children were taken from the school databases. Anthropometric indices, including weight and height, were measured twice for each individual, and the means of weight and height were used for the purpose of analysis. Weight and height were measured for children wearing light clothing, without shoes or other things that can affect results of weight and height measuring. The measurements were repeated at 0,3 , and 6 months in the time study. Body mass index (BMI) was calculated as the weight per square of the height $\left(\mathrm{kg} / \mathrm{m}^{2}\right)$. 
The nutritional status of the children was classified using criteria of sex-specific weight-for-age (W/A), height-for-age (H/A), weight-for-height $(\mathrm{W} / \mathrm{H}) \mathrm{z}$-score for children aged under 5 proposed by the World Health Organization in 2006 [9]. Z-score is the deviation of an individual's value from the median value of a reference population, divided by the standard deviation of the reference population (such as National Center for Health Statistics, NCHS) [9].

Children nutritional status was determined and assigned into one of the following categories: malnutrition (underweight, stunting, wasting and coordination), normal nutritional status, over-nutrition (overweight, obesity); weight/height ratios were also identified for a specific age.

Children with below -2 standard deviations ( $-2 \mathrm{SD})$ of the WHO median for W/A z-score, H/A z-score, and W/L z-score were considered to suffer from underweight, stunting or wasting respectively. And children with deviations from $+2 \mathrm{SD}$ to $+3 \mathrm{SD}$ and over +3 SD of the WHO median for $\mathrm{W} / \mathrm{H}$ $\mathrm{z}$-score were considered to suffer from overweight and obesity.

\subsection{Statistical analysis}

Data were imported and statistically processed with EpiData software, Microsoft Excel, and SPSS 16.0 software. The qualitative variables were represented by quantity (n) and percentage (\%), and compared by the $\chi 2$ test. Quantitative variables were checked for standard distribution. If variables were standard distribution, they were expressed as a mean \pm SD and compared by Student T test. If variables were non-standard distribution, they were expressed as a median $(25$ th -75 th percentile) and compared by Mann-WhitneyU test. Determining the correlation of anthropometric indices and age was based on the function $\mathrm{f}(\mathrm{x})=\mathrm{ax}+\mathrm{b}$ with $\mathrm{R}^{2}$ value. $P$ values of $<0.05$ for both sides were considered significant.

\section{Results and discussion}

\subsection{Characteristics of the research objects}

The characteristics of 2,035 children from 11 preschools in Hanoi, Nam Dinh and, Thanh Hoa are presented in Table 1.

The most part of the data were collected in Hanoi with 904 chidlren (44.42\%), followed by Nam Dinh with 609 children $(29.93 \%)$ and minimum in Thanh Hoa with 522 children $(25.65 \%)$. Among them, there were 1,113 boys $(54.7 \%)$ and 922 girls $(45.3 \%)$. The sex ratio in this study is 120.7 boys/100 girls. This ratio is higher than the sex ratio at birth in Vietnam in 2009 ( 110,6 boys/100 girls) according to the General Statistics Bureau [10].

Results in Table 1 showed that anthropometric indices in this study such as weight, height, BMI z-score, W/H z-score changed according to an age and mean values for the population (with $P<0.0001$ ).

The study had three stages, and there was a three months break between them. Children's weight and height were increment. In detail, at stage 1, children's age was 42 months, mean weight and height were $14 \mathrm{~kg}$ and $95 \mathrm{~cm}$, respectively. At stage 2, mean weight and height were $14.2 \mathrm{~kg}$ and $97 \mathrm{~cm}$ and at stage 3 , they were $15 \mathrm{~kg}$ and $99 \mathrm{~cm}$. After 6 months, children's weight increased by $1 \mathrm{~kg}$, but the increase was not uniform, weight increased

Table 1

Participants' sampling as per age groups, divided by sex and totally

\begin{tabular}{|l|c|c|c|c|c|c|}
\hline \multirow{2}{*}{ Age group } & \multicolumn{2}{|c|}{ Boys } & \multicolumn{2}{c|}{ Girls } & \multicolumn{2}{c|}{ Total } \\
\cline { 2 - 7 } & $n$ & $\%$ & $n$ & $\%$ & $n$ & $\%$ \\
\hline $10-24$ months & 76 & 6.83 & 53 & 5.75 & 129 & 6.34 \\
\hline $25-36$ months & 296 & 26.59 & 240 & 26.03 & 536 & 26.34 \\
\hline $37-48$ months & 489 & 43.94 & 399 & 43.28 & 888 & 43.64 \\
\hline $49-60$ months & 252 & 22.64 & 230 & 24.94 & 482 & 23.68 \\
\hline $10-60$ months & 1113 & 100 & 922 & 100 & 2035 & 100 \\
\hline
\end{tabular}


Anthropometric characteristics in children aged 10-60 months

\begin{tabular}{|l|c|c|c|c|c|c|}
\hline \multicolumn{1}{|c|}{ Characteristic } & Stage 1 & Stage 2 & Stage 3 & $P_{1-2}$ & $P_{2-3}$ & $P_{1-3}$ \\
\hline Age & $\begin{array}{c}42,68 \\
(35.22-48.62)\end{array}$ & $\begin{array}{c}45 \\
(38-51)\end{array}$ & $\begin{array}{c}48,0 \\
(40.97-54.0)\end{array}$ & $<0.0001$ & $<0.0001$ & $<0.0001$ \\
\hline Height & $\begin{array}{c}95,0 \\
(89.5-101)\end{array}$ & $\begin{array}{c}97 \\
(92-103)\end{array}$ & $\begin{array}{c}99 \\
(93-105)\end{array}$ & $<0.0001$ & $<0.0001$ & $<0.0001$ \\
\hline $\begin{array}{l}\text { H/A } \\
\text { z-score }\end{array}$ & $\begin{array}{c}-0.89 \\
(-1.74--0.02)\end{array}$ & $\begin{array}{c}-0.51 \\
(-1.25-0)\end{array}$ & $\begin{array}{c}-0.71 \\
(-1.43-0)\end{array}$ & $<0.0001$ & 0.101 & $<0.0001$ \\
\hline Weight & $\begin{array}{c}14,0 \\
(12.5-15.6)\end{array}$ & $\begin{array}{c}14,2 \\
(13.0-16.0)\end{array}$ & $\begin{array}{c}15.0 \\
(13.5-17)\end{array}$ & $<0.0001$ & $<0.0001$ & $<0.0001$ \\
\hline $\begin{array}{l}\text { W/A } \\
\text { z-score }\end{array}$ & $\begin{array}{c}-0.62 \\
(-1.3-0.12)\end{array}$ & $\begin{array}{c}-1-0,06 \\
(-1.0-0.04)\end{array}$ & $<0.0001$ & 0.259 & $<0.0001$ \\
\hline BMI & $(14.49-16.51)$ & $(14-16,18)$ & $(14.51-16.54)$ & 0,006 & $<0.0001$ & 0.301 \\
\hline $\begin{array}{l}\text { BMI } \\
\text { z-score }\end{array}$ & $\begin{array}{c}-0.04 \\
(-0.78-0.77)\end{array}$ & $\begin{array}{c}0 \\
(0-0.67)\end{array}$ & $\begin{array}{c}15 \\
(-0.14-0.9)\end{array}$ & $<0.0001$ & 0.001 & $<0.0001$ \\
\hline $\begin{array}{l}\text { W/H } \\
\text { z-score }\end{array}$ & $\begin{array}{c}-0.14 \\
(-0.84-0.61)\end{array}$ & $(-0.11-0.46)$ & $(-0.12-0.58)$ & $<0.0001$ & $<0.0001$ & $<0.0001$ \\
\hline
\end{tabular}

Scale comparison between 2 groups was performed with $\chi^{2}$ test. Variables were presented by median $\left(25^{\text {th }}-75^{\text {th }}\right.$ percentile), $P$ was received from Mann-Whitney $\mathrm{U}$ test.

$0.2 \mathrm{~kg}$ at stage 2 and $0.8 \mathrm{~kg}$ at stage 3 (with $P<0.0001)$. In addition, children's height increased by $4 \mathrm{~cm}$ after 6 months, approximately by $0.67 \mathrm{~cm}$ per 1 month. This showed that height increased stably. These results were comparable with the results obtained by Phuong H.V. et al in 2015 in the Red river delta in research performed on children aged 36-59 months (mean weight and height were $14.7 \mathrm{~kg}$ and $98.5 \mathrm{~cm}$, respectively) [11]. The values of anthropometric indices were within the range from -2 SD to +2 SD, so children's weight and height could be considered normal for their age. BMI z-score at stage 2 and 3 was 0 SD (standard deviation) and was higher than that at stage 1 (with $P<0.05$ ), because weight was gained faster than height grew.

According to data obtained in general nutrition survey performed in 2009-2010 on children under 5 years old, W/A z-score, H/A z-score, $\mathrm{W} / \mathrm{H}$ z-score were -0.82, -0.86, -0.47, respectively [7]. So, since 2010, nutritional status among Vietnamese children under 5 years has improved. According to data obtained in research that included 145,078 children aged 3-6 years in Tianjin, China and was performed from 2006 to 2014, mean val- ues of height z-scores increased significantly (from 0.34 to 0.54 ), mean values of weight z-scores were constant, and mean values of BMI z-scores decreased significantly (from 0.40 to 0.23 ) [12].

\subsection{The correlation between anthropometric indices and age}

All models show the correlation between anthropometric indices and age among children aged $10-60$ months $(P<0.05)$. However, only model $y=0.2736 x+2.8943$ with $R^{2}=0.8571$ showed the tight correlation between BMI and age. This can explain $85 \%$ of the difference in BMI among children aged 10-60 month in this study. Presumably, BMI determined as per the WHO criteria can be used to classify the nutritional status among Vietnamese children aged 10-60 months.

\subsection{The prevalence of nutritional status among children aged 10-60 months}

We used the WHO 2006 standard to assess the nutritional status of children; the result was presented in Table 3. At stage 3, children had all nutritional status types: malnutrition, normal status, overweight, obesity, 


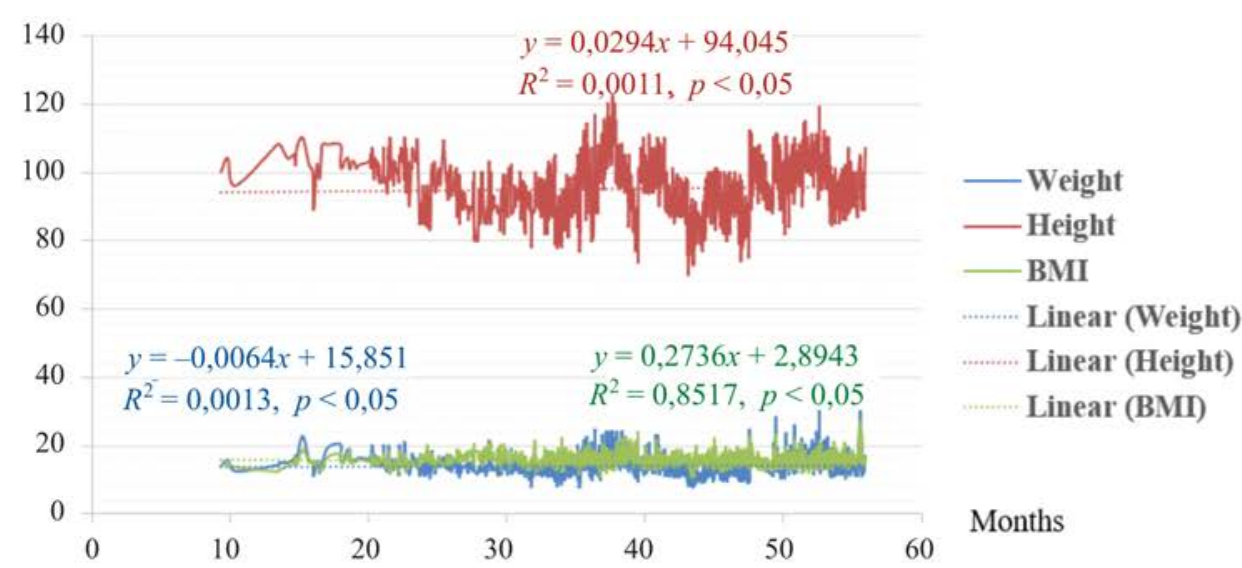

a. weight, height, BMI

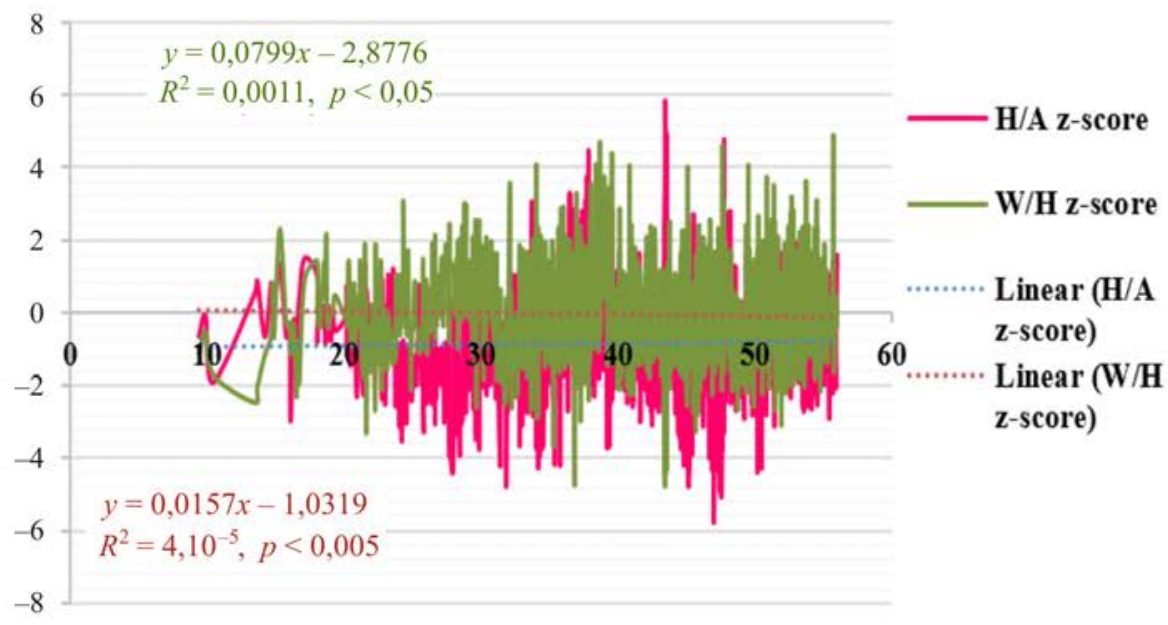

b. Z-score $\mathrm{H} / \mathrm{A}$ and $\mathrm{Z}$-score $\mathrm{W} / \mathrm{H}$

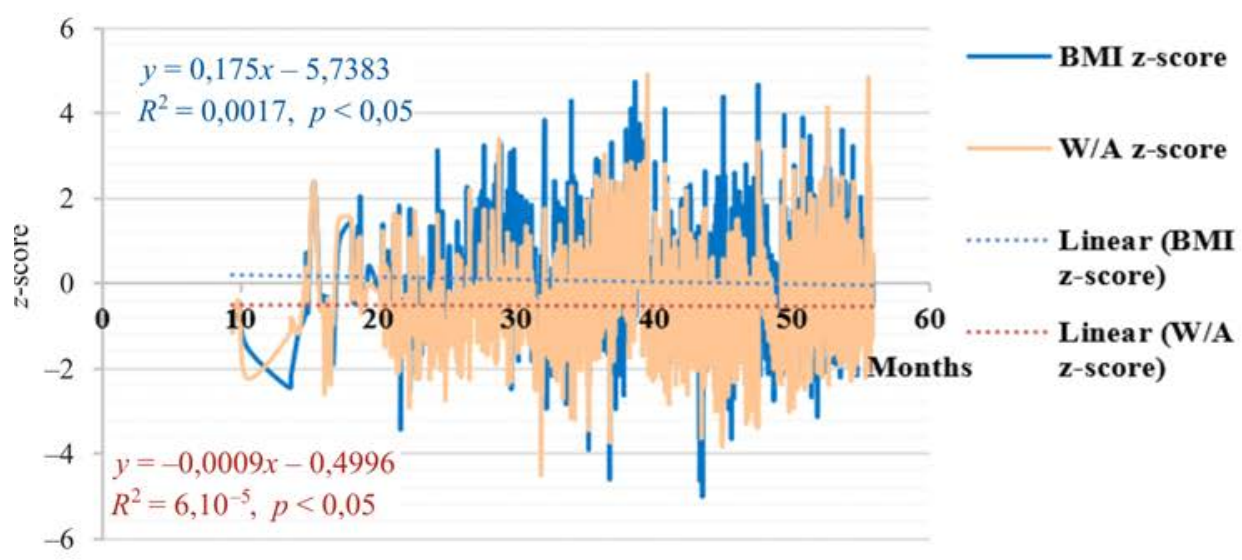

c. Z-score W/A and Z-score BMI

Figure 1. Shows the correlation between anthropometric indices:

a) weight, height, BMI; b) H/A z-score and W/A z-score;

c) W/H z-score and BMI z-score with age from 10-60 months 
Table 3

The correlation between anthropometric indices and age among children aged 10-60 months in Hanoi, Nam Dinh and Thanh Hoa

\begin{tabular}{|l|c|c|c|c|c|c|c|c|c|}
\hline \multirow{2}{*}{\multicolumn{1}{|c|}{ Nutritional status }} & \multicolumn{3}{|c|}{ Stage 1 } & \multicolumn{3}{c|}{ Stage 2 } & \multicolumn{3}{c|}{ Stage 3 } \\
\cline { 2 - 12 } & Boys & Girls & Total & Boys & Girls & Total & Boys & Girls & Total \\
\hline Normal & 72.9 & $74.0^{*}$ & 73.4 & 76.4 & 76.7 & 76.5 & 77.3 & $77.8^{*}$ & 77.5 \\
\hline Underweight & 7.9 & 8.0 & 7.9 & 5.2 & 5.9 & 5.6 & 3.9 & 4.7 & 4.3 \\
\hline Stunting & 18.1 & 19.8 & 18.8 & 16.2 & 17.0 & 16.6 & 15.0 & 16.6 & 15.7 \\
\hline Wasting & 3.6 & 3.8 & 3.7 & 1.9 & 2.4 & 2.1 & 1.4 & 1.7 & 1.5 \\
\hline Overweight & 6.0 & $2.8^{*}$ & 4.5 & 6.3 & $3.7^{*}$ & 5.1 & 7.0 & $3.7^{*}$ & 5.5 \\
\hline Obesity & 1.7 & $0.5^{*}$ & 1.2 & 1.8 & $0.8^{*}$ & 1.3 & 1.7 & $0.4^{*}$ & 1.1 \\
\hline Underweight and stunting & 5.3 & 5.4 & 5.4 & 4.0 & 4.4 & 4.2 & 2.8 & 4.0 & 3.3 \\
\hline Underweight and wasting & 1.2 & 1.5 & 1.3 & 0.5 & 0.5 & 0.5 & 0.4 & 0.1 & 0.2 \\
\hline $\begin{array}{l}\text { Underweight, stunting and } \\
\text { wasting }\end{array}$ & 0.5 & 0.4 & 0.5 & 0.4 & 0.1 & 0.2 & 0.2 & 0 & 0.1 \\
\hline Stunting and overweight & 0.7 & $0.4^{*}$ & 0.6 & 0.6 & $0.4 *$ & 0.5 & 0.9 & $0.3^{*}$ & 0.6 \\
\hline Stunting and obesity & 0.1 & 0.1 & 0.1 & 0.1 & 0.1 & 0.1 & 0.1 & 0.1 & 0.1 \\
\hline
\end{tabular}

Data were presented in $\%$, * means the difference between boys and girls is statistically significant.

and two disorders together (underweight and stunting, underweight and wasting...). After 6 months, good nutritional status increased incrementally, and bad nutritional status decreased, especially malnutrition. This highlights the significance of regular assessment of nutritional status in children under 5 years. Children develop actively and fast at this age, so it is very important to detect bad nutritional status timely to help families, schools and the community to react quickly and provide children with good nutrition necessary for their comprehensive development.

At stage 3, among malnutrition, the prevalence of stunting was the highest (15.7\%), next to underweight $(4.3 \%)$, underweight and stunting (3.3\%), wasting (1.5\%), underweight and wasting $(0.2 \%)$, underweight, stunting and wasting $(0.1 \%)$. The prevalence of overweight and obesity did not decrease with $4.5 \%$ overweight and 1.2\% obesity at stage 1 , and $5.5 \%$ overweight and $1.1 \%$ obesity at stage 3 , respectively. In addition, sometimes malnutrition and overweight occurred together: stunting and overweight $(0.6 \%)$, stunting and obesity $(0.1 \%)$.

The total share of stunting was $19.8 \%$, and the total share of underweight was $7.9 \%$, the share of wasting amounted to $1.8 \%$. These figures are lower than those obtained by the
National Institute of Nutrition in research performed among children under 5 years in Vietnam in 2010 with $29.3 \%$ of stunting, $17.5 \%$ of underweight, and $7.1 \%$ of wasting [7]. This showed that the prevalence of malnutrition among children under 5 years decreased significantly. A study among children aged 6-59 months from Northern Ethiopia showed high prevalence of malnutrition $(47.3 \%$ of stunting, $25.6 \%$ of underweight, and $8.9 \%$ of wasting) [13]. The study in six districts of Kilimanjaro showed high prevalence of underweight $(46.0 \%)$, stunting $(41.9 \%)$ and wasting (24.7\%). In further analysis, $21.1 \%$ children turned out to suffer from both underweight and wasting, $12.1 \%$ had wasting and stunting, and $32.5 \%$ had underweight and stunting; and $12 \%$ of children had all three nutritional status disorders [14]. So, if we fail to reduce the stunting condition, children will be exposed to the long term effects of stunting and may not reach their full growth potential [15].

The prevalence of over-nutrition among children under 5 years in this study amounted to $7.3 \%$. there was an increase in the figure in comparison with previous data obtained by the National Institute for Nutrition in 2009-2010 $(5.6 \%)$, of which the obesity prevalence was $2.8 \%$, and as for urban areas, the prevalence of 
over-nutrition was $6.5 \%$ there [7]. However, the prevalence of over-nutrition in this study is lower than that in Turkey (with $8.6 \%$ for overweight and $6.6 \%$ for obesity) among children under 5 years [16] and in Lebanon (with $6.5 \%$ for overweight and $2.7 \%$ for obesity) [17], and higher than that in Sub-Saharan Africa (with 6.8\% overweight/obesity) [18]. A community based cross-sectional study conducted in Gondar City showed the combined prevalence of overweight/obesity was $13.8 \%$ with overweight accounting for $9.6 \%$ and obesity for $4.2 \%$ of the total figure [19]. According to a longitudinal study performed on 2,677 Vietnamese children aged 3-6 years in 2013, 2014 and 2016, the overall estimated prevalence of overweight increased from 9.1\% to $16.7 \%$ and the overall prevalence off obesity decreased from $6.4 \%$ to $4.5 \%$ [20]. However, between 2006 and 2014 in China, there were no significant changes in prevalence of overweight and obesity among 3-4 years children. Nevertheless, prevalence of obesity increased from $8.8 \%$ in 2006 to $10.1 \%$ in 2010 , and then remained stable until 2014 among 5-6 year old children [12].

According to the national nutrition strategy accepted for 2011-2020, the prevalence of stunting and underweight in this study has achieved the target level fixed by the government [21]. In comparison with the study of Phuong H.V. performed on 39-59 month children in Thanh Liem, a Red River Delta district, the prevalence of stunting, underweight and wasting was $18.1 \%, 11.3 \%$ and $3.1 \%$; overweight and obesity was low at $1.9 \%$ [11]. So stunting and overweight in Hanoi, Nam Dinh and Thanh Hoa are still a public healthcare problem; to solve it, we need to improve nutritional status among preschool children.

In addition, normal nutrition status in girls was higher than in boys $(74.0 \%$ against $72.9 \%$, at stage 1 , and $77.8 \%$ against $77.3 \%$ at stage 3) with $P<0.05$. On the contrary, the total prevalence of overweight and obesity in boys was higher than in girls $(7.9 \%$, $1.8 \%$ against $4.0 \%, 0.5 \%$ respectively at stage 3). Similar results were obtained in the study performed in Northwest Ethiopia with prevalence of obesity equal to $7.4 \%$ among boys and 1.2\% among girls [19]; in China, boys also had higher prevalence of obesity than girls [12]. This might be explained by the differences in gender-dependent behaviors of children and family childcare. Although, no significant differences between genders were observed in a national crosssectional survey among 2-5 year old children in Lebanon [17]. So this discrepancy needs to be evaluated in details to provide appropriate strategy to control nutritional status for each gender of children.

\section{Conclusions}

The research results revealed a tight correlation between BMI and the children's age among preschool children, and roved that using BMI according to the WHO data to assess the nutritional status of children at this age was appropriate. Substantial number of children aged from 10 to 60 months in the Northern Vietnam suffer from both overweight and obesity, as well as underweight, wasting, and stunting. The regular assessment of anthropometric indicies has a positive effect, helping families and communities to evaluate nutritional status, thus ensuring a child has all th possibilities for further harmonious development.

Acknowledgments. Research has been accomplished due to financial support (funding) granted by the Ministry of Education and Training, Vietnam and Hanoi National University of Education, grant no B2018-SPH-50.

Conflict of interests. The authors state there is no any conflict of interests. 


\section{References}

1. Nguyen Thi Hong Hanh, Duong Thi Anh Le Thi Tuyet, Yang Tao Dao, Dinh-Toi Chu. Childhood obesity is a high-risk factor for hypertriglyceridemia: a case-control study in Vietnam. Osong public health and research perspectives, 2017, vol. 8, no. 2, pp. 138.

2. Nutrition-Challenges. World Health Organization, 2017. Available at: http: //www.who. int/nutrition/challenges/en/ (30.07.2018).

3. Goodarz D., Kathryn G.A., Christopher R.S., Günther F., Charles McCoy D., Peet E., Sania A., Smith Fawzi M.C., Ezzati M., Fawzi W.W. Risk factors for childhood stunting in 137 developing countries: a comparative risk assessment analysis at global, regional, and country levels. PLoS medicine, 2016, vol. 13, no. 11, pp. e1002164.

4. Le Thi Tuyet, Bui Thi Nhung, Duong Thi Anh Dao, Nguyen Thi Hong Hanh, Le Danh Tuyen, Tran Quang Binh, Vu Thi Minh Thuc. The Brain-Derived Neurotrophic Factor Val66Met Polymorphism, Delivery Method, Birth Weight, and Night Sleep Duration as Determinants of Obesity in Vietnamese Children of Primary School Age. Childhood Obesity, 2017, vol. 13, no. 5, pp. 392-399.

5. Black R.E., Victora C.G., Walker S.P., Bhutta Z.A., Christian P., de Onis M., Ezzati M., GranthamMcGregor S., Katz J., Martorell R., Uauy R. Maternal and child undernutrition and overweight in lowincome and middle-income countries. The Lancet, 2013, vol. 382, no. 9890, pp. 427-451.

6. World Health Statistics. 2015. Geneva, World Health Organization, 2015. Available at: http: //apps.who.int/iris/bitstream/10665/170250/1/9789240694439_eng.pdf?ua=1 (30.07.2018).

7. Summary report general nutrition survey 2009-2010. Hanoi, National Institute of Nutrition and United Nations Children's Fund, 2012, 33 p.

8. Wayne W.D., Cross C.L. Biostatistics: a foundation for analysis in the health sciences. Wiley, 2013. $-960 \mathrm{p}$.

9. WHO child growth standards: length/height for age, weight-for-age, weight-for-length, weight-for-height and body mass index-for-age, methods and development. 2006. Geneva, World Health Organization, 2006, $312 \mathrm{p}$.

10. Population and house census in Viet Nam 2009, Sex Ratio at Birth in Viet Nam: New Evidence on Status, Trends and Differences. The Ministry of Planning and Investment and General Statistics Bureau, 2011. Hanoi, Medical Publising House, 2011, 24 p.

11. Hoang Van Phuong, Le Danh Tuyen, Tran Thuy Nga, Nguyen Song Tu, Ha Anh Duc. Nutritional status of preschool children aged 36-59 months in Thanh Liem, a Red River Delta district, 2015. Vietnam Journal of Preventive medicine, 2017, vol. 27, no. 6, pp. 184-192.

12. Yanyu Xiao, Yijuan Qiao, Lei Pan, Jin Liu, Tao Zhang, Nan Li, Enqing Liu, Yue Wang, Hongyan Liu, Gongshu Liu, Guowei Huang, Gang Hu. Trends in the Prevalence of Overweight and Obesity among Chinese Preschool Children from 2006 to 2014. PloS one, 2015, vol. 10, no. 8, pp. e0134466-e0134466.

13. Amsalu F., Bikes D.B. Prevalence and Factors Associated with Stunting, Underweight and Wasting: A Community Based Cross Sectional Study among Children Age 6-59 Months at Lalibela Town, Northern Ethiopia. Journal of Nutritional Disorders \& Therapy, 2014, vol. 4, pp. 2.

14. Mgongo M., Chotta N., Hashim T., Uriyo J., Damian D., Stray-Pedersen B., Msuya S., Wandel M., Vangen S. Underweight, Stunting and Wasting among Children in Kilimanjaro Region, Tanzania; a Population-Based Cross-Sectional Study. International Journal of Environmental Research and Public Health, 2017, vol. 14, no. 5, pp. 509.

15. The state of food insecurity in the world 2014. Strengthening the enabling environment for food security and nutrition. Pome, Food and Agriculture Organization of the United Nations, 2014. Available at: http://www.fao.org/3/a-i4030e.pdf (30.07.2018).

16. Santas F., Santas G.. Prevalence of pre-school children for overweight/obesity in Turkey. World Journal of Pediatrics, 2018, vol. 14, no. 1, pp. 77-83. 
17. Nasreddine L., Hwalla N., Saliba A., Akl C., Naja F.. Prevalence and Correlates of Preschool Overweight and Obesity Amidst the Nutrition Transition: Findings from a National Cross-Sectional Study in Lebanon. Nutrients, 2017, vol. 9, no. 3, pp. 266.

18. Gebremedhin S. Prevalence and differentials of overweight and obesity in preschool children in Sub-Saharan Africa. BMJ open, 2015, vol. 5, no. 12, pp. e009005-e009005.

19. Sorrie M.B., Yesuf M.E., GebreMichael T.G. Overweight/Obesity and associated factors among preschool children in Gondar City, Northwest Ethiopia: A cross-sectional study. PloS one, 2017, vol. 12, no. 8, pp. e0182511-e0182511.

20. Do L.M., Tran T.K., Eriksson B., Petzold M., Ascher H.. Prevalence and incidence of overweight and obesity among Vietnamese preschool children: a longitudinal cohort study. BMC Pediatrics, 2017, vol. 17, no. 1, pp. 150-150.

21. Policy - National Nutrition Strategy for 2011-2020, With a vision toward 2030. Hanoi: Medical Publishing House, 2012. Avaialble at: https: //extranet.who.int/nutrition/gina/en/node/11519 (30.07.2018).

Nguyen Thi Trung Thu, Le Thi Thuy Dung, Le Thi Tuyet. Nutritional status: the trends of preschool children aged 10-60 months in the north of vietnam. Health Risk Analysis, 2018, no. 4, pp. 57-65. DOI: 10.21668/health.risk/2018.4.06.eng

Received: 09.11.2018

Accepted: 18.12 .2018

Published: 30.12.2018 
UDC 614.7: 616-01/-099

DOI: $10.21668 /$ health.risk/2018.4.07.eng

\title{
HYGIENIC ASSESSMENT OF ENVIRONMENTAL FACTORS THAT CAUSE INSUFFICIENT PROVISION WITH VITAMINS AMONG PRE-SCHOOL CHILDREN
}

\author{
A.M. Yambulatov ${ }^{1}$, O.Yu. Ustinova ${ }^{2,3}$ \\ ${ }^{1}$ Federal Service for Surveillance over Consumer Rights Protection and Human Well-being, Perm Regional Office, \\ 50 Kuybyisheva Str., Perm, 614016, Russian Federation \\ ${ }^{2}$ Federal Scientific Center for Medical and Preventive Health Risk Management Technologies, 82 Monastyrskaya Str., \\ Perm, 614045, Russian Federation \\ ${ }^{3}$ Perm State University, 15 Bukireva Str., Perm, 614990, Russian Federation
}

An issue related to insufficient provision with vitamins among children in Russia requires profound examination, especially as regards reasons for it, as it will allow to work out targeted prevention measures. Our research goal was to perform hygienic assessment of environmental factors (organization of nutrition, chemical contamination of environmental objects) that influence provision of preschool children with vitamins. We chose the following research objects: a typical pre-school children facility located in a large industrial center and 188 children aged 6-7 who attended it. We applied a set of sanitary-hygienic, laboratory, and mathematical techniques in our research. We assessed organization of nutrition in the facility; performed a comparative analysis of nutrition quality with calculation and individual weighting technique. We also examined concentrations of technogenic chemicals in the atmospheric air, the air inside the facility, and water supplied to the facility; determined their concentrations in children's blood; studied antioxidant protection system in children and a level of their provision with vitamins. We detected that nutrition in the facility was imbalanced, and actual consumption of some food products was up to 1.7 times lower that it was suggested in a menu, and actual introduction of vitamins was by $30 \%$ lower than calculated one. We showed that environmental objects (the atmospheric air, indoor air, and drinking water supplied to the facility) on industrially developed territories were contaminated with technogenic chemicals (formaldehyde, phenol, ethylbenzene, chloroform, and residual free/fixed chlorine) and it led to occurrence of their increased concentrations and increased concentrations of their metabolites in children's blood. We proved that increased concentrations of oxygen-containing aldehydes, aromatic hydrocarbons, and chlorine-organic compounds in children's blood made antioxidant protection enzymes less active and caused lower concentrations of antioxidant-active vitamins. So, insufficient provision with vitamins among pre-school children who attend a preschool children facility in a large industrial center is caused not only by insufficient exogenous introduction of vitamins with food but also by effects of their metabolic absorption related to occurrence of technogenic chemicals with pro-oxidant effects in biological media.

Key words: children, pre-school children facilities, hygienic assessment, nutrition, vitamins, rations and nutrition quality, technogenic chemicals.

Introduction. Rational and balanced nutrition makes for optimal metabolism necessary for proper physical and mental development of children while vitamins and microelements deficiency in daily ration leads to 1.5-3.0 times increase in probability of chronic diseases development even at an early age $^{1}[1-3]$. Research performed in the Russian Federation in 2000-2015 revealed that there was an urgent issue related to improper provision with vitamins among more than $70 \%$ of children regardless of a season, age, or a place where a child lived $[1,4,5]$. Insuf- ficient provision with vitamins (primarily A, C, D and B group) was close to hypovitaminosis in some cases; its frequency reached $90 \%$ in some Russian regions and this disorder had a complex nature in $2 / 3$ of children $[6,7]$. It was detected that frequency of insufficient provision with vitamins among children was often equal to $70 \%$ and more on industrially developed territories in spite of better social and economic conditions and higher living standards there $[6,8-10]$.

Most experts consider insufficient provision with vitamins among children to be caused

(C) Yambulatov A.M., Ustinova O.Yu., 2018

Aleksandr M. Yambulatov - chief specialist of the Department for Supervision of Food Hygiene (e-mail: random799@mail.ru; tel.: +7 (342) 236-32-64; ORCID: http://orcid.org/0000-0002-4098-5583).

Olga Yu. Ustinova - Doctor of Medicine, Associate Professor, Deputy Director for Healthcare Services; Associate Professor, professor of the Department of human ecology and life safety (e-mail: ustinova@fcrisk.ru; tel.: +7 (342) 236-32-64; ORCID: http://orcid.org/0000-0002-9916-5491).

${ }^{1}$ Polyakova A.S. Assessment of nutritional status among primary school children and substantiation of activities required to optimize it: thesis of a dissertation for Candidate of Medical Sciences degree. - N. Novgorod, 2005. - 24 p. 
by non-rational nutrition structure, storage procedures and processing technologies applied in food manufacturing, and with low natural concentrations of vitamins in products as well $[11,12]$. It was detected that at present a daily ration, even balanced and variable one, still had most vitamins in quantities that were 20-30\% lower than physiological standards $[5,6,13,14]$. Results of multi-focused research on actual nutrition offered to children at preschool children facilities revealed that it was frequently imbalanced, rations had excessive caloric values, but there was not sufficient quantity of proteins in them as they predominantly contained carbohydrates; fresh fruit, meat, and fermented milk products were also in deficiency [4, 5]. Experts analyzed nutrition consumed by pre-school children at their homes and revealed that nutrition regimes were often violated and children often ate food that was not recommended for children nutrition (culinary products fried in deep fat, chips, snacks, and carbonated drinks) [15-17]. Such "western" food doesn't provide physiological balance of nutrients consumed with it, including vitamins, and, consequently, causes health disorders among children $[5,6,18]$.

At the same time, chemical environmental factors also exert significant influence on children provision with vitamins $[10,19,20]$. Chronic introduction of technogenic chemicals into a child's body causes elevated concentrations of toxicants in biological media accompanied with a significant increase in activity of free radical oxidation processes and, consequently, with greater consumption of vitamins participating in antioxidant protection $[5,15$, 18]. Most experts believe that technogenic chemicals produce the most adverse effects on concentrations of retinol and its ethers, riboflavin, pyridoxine hydrochloride, pantothenic, ascorbic, and folic acids, cholecalciferol, ergocalciferol, and rutin $[2,5,6,11]$.
Our research goal was to perform hygienic assessment of environmental factors (organization of nutrition and chemical contamination of environmental objects) that influence provision with vitamins among pre-school children.

\section{Data and methods.}

We chose the following research object: a typical pre-school children facility located in a large industrial center and 188 children aged 6-7 who attended it. To perform the research, we applied a set of sanitary-hygienic, laboratory, and mathematical techniques. Medical and biological research was accomplished in full conformity with ethical principles fixed in Helsinki Declaration approved in 1975 and last supplemented in 1983 and the RF National Standard GOST-R 52379-2005 2 .

To perform sanitary-hygienic assessment of nutrition in the pre-school children facility, we took data collected during scheduled inspections accomplished by Rospotrebnadzor Regional office in Perm in 2016-2017. We examined nutrition quality and how well it was provided with vitamins via calculations that were based on data taken from menus, technological charts, and rejection logs. We assessed actual nutrition consumed by 120 children at the pres-school children facility with an individual weight method [11].

To study influence exerted by chemical environmental factors on violations of provision with vitamins, we performed a profound laboratory examination of 188 children who had been attending the pres-school facility for not less than 3 years.

Atmospheric air samples were taken on the territory of the pre-school children facility and inside it in conformity with the existing regulatory documents ${ }^{3}$. Formaldehyde was detected in air samples via high-performance liquid chromatography ("Agilent 1200 Series" liquid chromatograph with diode-matrix detector); ethylbenzene was detected via gas chromatography ("Kristall 5000" gas chromatograph with

\footnotetext{
${ }^{2}$ GOST R 52379-2005. Good clinical practice: The RF National Standard. (ICH E6 GCP) [web-source] // KODEKS: an electronic fund of legal and reference documentation. - URL: http://docs.cntd.ru/document/1200041147 (date of visit August 16, 2018).

${ }^{3}$ GOST (State Standard) 17.2.3.01-86. Environmental protection. Atmosphere. Rules for control over air in settlements [web-source] // Gost.one. - URL: https://dev.gost.one/document/GOST_17230186-57912 (date of visit August 16, 2018).

GOST (State Standard) R ISO 16000-1-2007. Air in closed rooms. Part 1. Sampling. General provisions: The RF National Standard [web-source] // KODEKS: an electronic fund of legal and reference documentation. - URL: http://docs.cntd.ru/document/gost-r-iso-16000-1-2007 (date of visit August 16, 2018).
} 
HP-FFAP $50 * 0.32 * 0.50$ capillary column and flame ionization detector); phenol was detected via spectrophotometry ("Lambda" spectrophotometer, "PerkinElmer" Inc., the USA), in conformity with existing methodical and regulatory documents ${ }^{4}$. Average daily concentrations of chemicals were calculated as arithmetic mean of single concentrations in samples taken within one day. Drinking water quality in the pre-school children facility was estimated as per data collected during monitoring by the Federal Information Fund for Social and Hygienic Monitoring and field observation results. Chloroform and tetrachloromethane were detected via gas chromatography ("Chromatek-Kristall-5000" chromatograph with halogen-selective detector) ${ }^{5}$.

Concentrations of vitamins $\mathrm{B}_{6}$ and $\mathrm{B}_{12}$ in children's blood were detected with a microbiologic test combined with a colorimetric technique ("ID-Vit ${ }^{\circledR}$ Vitamin $B_{6}$ " and "ID-Vit ${ }^{\circledR} V i$ tamin $B_{12}$ ", Immunodiagnostik AG, Germany); concentration of vitamin $\mathrm{C}$ was detected with a colorimetric technique with a test system for detecting water-soluble vitamin $\mathrm{C}$ (Immunodiagnostik AG, Germany); concentrations of vitamins $\mathrm{A}, \mathrm{D}$ and $\mathrm{E}$ were detected with ELISA techniques ("Vitamin A, ELISA/Human Vitamin A, VA Elisa Kit, 96 CSB", CUSABIO BIOTECH, Co. Ltd., China; "25-OH vitamin D", "Euroimmune AG" Germany; "Vitamin E, ELISA/Human Vitamin E, VE Elisa Kit, 96 CSB", CUSABIO BIOTECH, Co. Ltd., China) ("ELx808IU" laboratory immunologic analyzer, "Infinite F50" ELISA microplate reader).

To assess strain that occurred in oxidativeantioxidant reactions in examined children, we determined overall antioxidant activity of blood serum, lipid hydroperoxides and malonic dialdehyde concentrations, superoxide dismutase and glutathione peroxidase ("Konelab" automatic biochemical analyzer, "ELx808" ELISA absorbance microplate reader). Research was performed as per conventional procedures with standard test kits.

All the obtained data were analyzed with variation and frequency analysis taking into account Pierson criterion; numerical values validity was estimated as per Fischer and Student criteria; "technogenic chemicals concentration in blood - vitamin contents in blood" relationship and "vitamin concentration in blood - adverse effect marker" relationship were estimated as per odds ratio (OR) calculation and its confidence interval (CI). OR $\geq 1$ meant a correlation existed.

Our research was performed within the plan of scientific-research work approved by the Federal Scientific Center for Medical and Preventive Health Risk Management Technologies in accordance with the branch scientific-research program by Rospotrebnadzor entitled "Hygienic scientific substantiation for minimizing heath risks for the RF population" for 2016-2020.

Results and discussion. According to the data obtained during scheduled inspections, the kitchen unit at the examined pre-school children facility can't facilitate the complete cooking processes and operates with semicooked food; nevertheless, it is equipped with all the necessary technological, cooling, and washing devices. Children are provided with 5 meals a day (breakfast, brunch, lunch, mid-

\footnotetext{
${ }^{4}$ Determination of adverse substances in biological media: Methodical guidelines. - M.: Rospotrebnadzor's Federal Center for Hygiene and Epidemiology, 2008. - 183 p.

MG 4.1.2110-06. Determining mass concentrations of formaldehyde, acetaldehyde, propionic aldehyde, butyric aldehyde and acetone in urine samples via high-performance liquid chromatography [web-source] // KODEKS: an electronic fund of legal and reference documentation. - URL: http://docs.cntd.ru/document/1200065242 (date of visit August 16, 2018).

MG 4.1.764-99. gas chromatography for quantification of aromatic hydrocarbons (benzene, toluene, ethylbenzene, o,$\mathrm{m}$,-p-xylene) in biological media (urine) [web-source] // KODEKS: an electronic fund of legal and reference documentation. URL: http://docs.cntd.ru/document/1200039011 (date of visit August 16, 2018).

MG 4.1.2108-06. Determining mass concentration of phenol in biological media (blood) via gas chromatography [websource] // KODEKS: an electronic fund of legal and reference documentation. - URL: http://docs.cntd.ru/document/1200065240 (date of visit August 16, 2018).

Guide 52.04.186-89 Guide for control over atmospheric contamination (Parts II and III. Appendices to Part I) [web-source] // KODEKS: an electronic fund of legal and reference documentation. - URL: http://docs.cntd.ru/document/1200037440 (date of visit August 16, 2018).

${ }^{5}$ MG 4.1.2115-06 Determining mass concentrations of chloroform, 1,2-dichloroethane, tetrachloromethane in biological media (blood) via gas chromatography analysis of equilibrium vapor [web-source] // KODEKS: an electronic fund of legal and reference documentation. - URL: http://docs.cntd.ru/document/1200065247 (date of visit August 16, 2018).
} 
afternoon snack, and dinner); breaks between meals don't last longer than 4 hours; there is a draft 10-day menu for children younger than 3 and from 3 to 7 years. Cooked food is enriched with vitamin $\mathrm{C}$ all the year round as it is prescribed by the Hygienic Requirements SER 2.4.1.3049-13 ${ }^{6}$. We examined the results obtained during scheduled inspections at the preschool children facility and analyzed data from daily menus and cumulative lists; our examination revealed that food satisfied all agerelated physiological needs of children in nutrients and energy. Assessment of actual meals provided for children didn't reveal any repeated dishes in 3 days menus and this fact, combined with met requirements to a daily set of products, proved that children were offered diverse ration. But at the same time, we studied quantitative characteristics of a menu and revealed that a set of products offered to chil- dren contained 3 times higher quantities of curds, curd products and fish, 1.4 times higher quantities of juices, fruit and vegetables, and 1.7 times higher quantities of sugar than it was fixed in consumption rates; however, milk and fermented milk products were offered in insufficient quantities (Table 1).

As we analyzed menus, technological charts, and rejection logs, we revealed that the total amount of food consumed by children and contents of basic nutrients and energy in daily ration as well conformed to the existing standards and regulations ${ }^{6}$ fixed for nutrition that should be provided for pre-school children. Our further research on daily ration offered to children in the pre-school children facility showed that protein contents accounted for $14.2 \pm 1.4 \%$ of its caloric value; fats accounted for $30,1 \pm 3.7 \%$; and carbohydrates, for $56.2 \pm$ $\pm 3.8 \%$. The figures met the requirements fixed

Table 1

Weight of products consumed by a child at the pre-school children facility compared with recommended hygienic standards (g/day, gross) ${ }^{6}$

\begin{tabular}{|l|c|c|c|}
\hline \multicolumn{1}{|c|}{$\begin{array}{c}\text { Food product } \\
\text { (group of food products }\end{array}$} & $\begin{array}{c}\text { Weight of products consumed } \\
\text { by a child at the pre-school children } \\
\text { facility (examined menus) }\end{array}$ & $\begin{array}{c}\text { Recommended weight } \\
\text { for daily consumption } \\
\text { by children aged 6-7 }\end{array}$ & $\begin{array}{c}\text { Validity } \\
\text { of discrepancy } \\
(p \leq 0.05)\end{array}$ \\
\hline $\begin{array}{l}\text { Milk and fermented milk } \\
\text { products with mass fraction } \\
\text { of fat not lower than 2.5\% }\end{array}$ & $399.1 \pm 107.8^{*}$ & $450^{*}$ & $\mathbf{0 . 0 4 1}$ \\
\hline $\begin{array}{l}\text { Curds, curd products with } \\
\text { mass fraction of fat not } \\
\text { lower than 5\% }\end{array}$ & $118.0 \pm 32.0^{*}$ & $40^{*}$ & $\mathbf{0 . 0 0 2}$ \\
\hline Sour cream & $18.4 \pm 14.0$ & 11 & 1.0 \\
\hline Meat & $102.8 \pm 74.1$ & 60.5 & 0.16 \\
\hline Rye bread (rye-white bread) & 50.0 & 50 & - \\
\hline White bread or grain bread & 80.0 & 80 & - \\
\hline Cereals and beans & $55.0 \pm 31.5$ & 43 & 0.07 \\
\hline Butter & $21.8 \pm 4.2$ & 21 & 0.28 \\
\hline Vegetable oil & $10.3 \pm 6.0$ & $47^{*}$ & 0.37 \\
\hline Sugar & $55.1 \pm 10.6^{*}$ & 114 & 0.0016 \\
\hline Fresh fruit & $126.3 \pm 59.4$ & $100^{*}$ & $\mathbf{0 . 1 * 1 0 ^ { - 5 }}$ \\
\hline Fruit (vegetable) juices & $135.7 \pm 59.4^{*}$ & $39^{*}$ & $1.71^{*} 10^{-5}$ \\
\hline Fish (fillet) & $86.2 \pm 20.9^{*}$ & 209 & 0.92 \\
\hline Potato & $211.5 \pm 106.1$ & 325 & 0.24 \\
\hline Vegetables and greenery & $278.7 \pm 173.6$ & & \\
\hline
\end{tabular}

${ }^{6}$ SER 2.4.1.3049-13. Sanitary-epidemiologic requirements to facilitating, maintenance, and organization of pre-school children facilities functioning: Sanitary-epidemiologic rules and standards [web-source] // KODEKS: an electronic fund of legal and reference documentation. - URL: http://docs.cntd.ru/document/499023522 (date of visit August 16, 2018). 
by the SER 2.4.1.3049-13 ${ }^{6}$ (where proteins account for $12-15 \%$; fats, for $30-32 \%$, and carbohydrates, for $55-58 \%$, accordingly) ${ }^{7}$ (Table 2 ).

We calculated and analyzed daily rations as regards provision with vitamins and revealed that every day children obtained $0.89 \pm 0.20 \mathrm{mg}$ of vitamin $\mathrm{B}_{1}, 1.0 \pm 0.3 \mathrm{mg}$ of vitamin $\mathrm{B}_{2}$, and $39.9 \pm 12.6 \mathrm{mg}$ of vitamin $\mathrm{C}$; the quantities corresponded to age-related physiological consumption rates $^{7}$ (Table 3 ).

We examined actual nutrition provided for children with an individual weight method and detected that children actually consumed 1.2-1.7 times less milk, meat, butter, and sugar than it was calculated (Table 4).

Actual amount of proteins consumed by a child, taking into account all the food he or she refused to finish up, was equal to only $54.2 \pm 10.4 \mathrm{~g}$; fats, $54.2 \pm 10.2 \mathrm{~g}$; carbohydrates, $205.9 \pm 17.5 \mathrm{~g}$; all the figures were on average by $17.5 \%$ lower than values obtained during analysis of menus when the same amounts were calculated theoretically. Simultaneously, actual amount of proteins consumed by children didn't have any authentic discrepancies from physiological standards (54 g; $p=0.27$ ), but consumption of fats and carbohydrates was authentically lower (60 g and $261 \mathrm{~g}$ respectively; $p=0.04-0.001$ ). caloric value of actually consumed ration amounted to only 1,522.8 \pm $\pm 111.9 \mathrm{kcal}$ and it was 1.2 times lower that a value obtained during analysis of menus when it was calculated theoretically $(p \leq 0.001)$ and authentically lower than the recommended hygienic standard (1,800 kcal; $p \leq 0.001)$ (Table 5).

The detected discrepancies between calculated and actual amounts are basically caused by children not finishing all the offered dishes up; losses of nutrients (carbohydrates and fats) and lower caloric value of ration, taking into account actual amounts consumed by children, reach $18.5 \%(p \leq 0.001)$. And as children tended to consume less fats and carbohydrates, a contribution made by these nutrients into overall caloric value of ration also decreased $(32.0 \pm 4.7 \%$ and $54.3 \pm 5.1 \%$ respectively). Simultaneously we detected poorer provision of children's nutrition with certain vitamins and microelements; thus, actual consumption of vitamins $\mathrm{B}_{1}$ and $\mathrm{B}_{2}$ was 1.2-1.3 times lower than the calculated value; $\mathrm{Fe}$ and $\mathrm{Ca}, 1.2-1.4$ times lower $(p=0.02-$ 0.001 ) which was next to the lower bound of the physiological need in them (Table 6).

Table 2

Comparative analysis of caloric value and nutrients contents in ration provided by the pre-school children facility and physiological needs

\begin{tabular}{|l|c|c|c|}
\hline $\begin{array}{c}\text { Energetic and } \\
\text { nutrient value }\end{array}$ & $\begin{array}{c}\text { Standard physiological needs in energy } \\
\text { and nutrients for children aged 3-711 }\end{array}$ & $\begin{array}{c}\text { Actual } \\
\text { provision }\end{array}$ & $\begin{array}{c}\text { Validity of discrep- } \\
\text { ancy }(p \leq 0.05)\end{array}$ \\
\hline Energy (kcal) & 1,800 & $1,864.0 \pm 134.1$ & 0.87 \\
\hline Protein, g & 54 & $66.3 \pm 9.3$ & 0.89 \\
\hline Fats, $\mathrm{g}$ & 60 & $62.5 \pm 9.8$ & 0.63 \\
\hline Carbohydrates, $\mathrm{g}$ & 261 & $261.3 \pm 19.1$ & 0.94 \\
\hline
\end{tabular}

Table 3

Comparative analysis of vitamins and minerals contents in ration provided by the pre-school children facility and physiological needs

\begin{tabular}{|c|c|c|}
\hline Vitamins and minerals & Analysis of menus, $\mathrm{mg}$ & ${\text { Children's physiological needs, } \mathrm{mg} / \text { day }^{\mathrm{Il}}}$ \\
\hline $\mathrm{B} 1$ & $0.89 \pm 0.2$ & $0.4-1.8 \mathrm{mg} /$ day \\
\hline $\mathrm{B} 2$ & $1.0 \pm 0.3$ & $0.3-1.5 \mathrm{mg} /$ day \\
\hline $\mathrm{C}$ & $39.9 \pm 22.6$ & $30-90 \mathrm{mg} / \mathrm{day}$ \\
\hline $\mathrm{Ca}$ & $784.3 \pm 95.7$ & $400-1200 \mathrm{mg} /$ day \\
\hline $\mathrm{Fe}$ & $15.8 \pm 6.0$ & $4-18 \mathrm{mg} /$ day \\
\hline
\end{tabular}

${ }^{7}$ Chemical structure of food products: Reference book / edited by I.M. Skurikhin, Professor, Corresponding member of the MAI, and V.A. Tutel'yan, Professor, Academician, member of the RAMS. - M.: DeLiprint, 2002. - 236 p. 
Table 4

Actual quantities of basic food products actually consumed by a child against calculated amounts: comparative analysis ( $\mathrm{g} /$ day, gross)

\begin{tabular}{|l|c|c|}
\hline \multicolumn{1}{|c|}{ Food products } & $\begin{array}{c}\text { Amounts calculated } \\
\text { as per menus }\end{array}$ & $\begin{array}{c}\text { Individual weight } \\
\text { method }\end{array}$ \\
\hline $\begin{array}{l}\text { Milk and fermented milk products with mass } \\
\text { fraction of fat not lower than 2.5\% }\end{array}$ & $399.1 \pm 107.8^{*}$ & $236.7 \pm 62.3^{*}$ \\
\hline $\begin{array}{l}\text { Curds, curd products with mass fraction of } \\
\text { fat not lower than 5\% }\end{array}$ & $118.0 \pm 32.0$ & $93.02 \pm 54.8$ \\
\hline Sour cream & $19.0 \pm 13.8$ & $18.8 \pm 14.1$ \\
\hline Meat (without bones) & $102.8 \pm 71.4^{*}$ & $62.8 \pm 55.7^{*}$ \\
\hline Fish (fillet) & $86.2 \pm 20.9$ & $77.2 \pm 19.2$ \\
\hline Potato & $211 \pm 106.1$ & $197.8 \pm 111.5$ \\
\hline Vegetables, greenery & $278.7 \pm 173.6$ & $203.71 \pm 122.8$ \\
\hline Fresh fruit & $126.3 \pm 59.4$ & $104.6 \pm 65.5$ \\
\hline Fruit (vegetable) juices & $135.7 \pm 55.6$ & $126.2 \pm 37.2$ \\
\hline Xлеб pжаной & 50.0 & 69.9 \\
\hline White bread & 80.0 & $41.7 \pm 26.3$ \\
\hline Cereals and beans & $49.5 \pm 34.3$ & $18.4 \pm 4.4^{*}$ \\
\hline Butter & $21.9 \pm 4.2^{*}$ & $8.8 \pm 4.6$ \\
\hline Vegetable oil & $9.8 \pm 6.0$ & $39.1 \pm 7.5^{*}$ \\
\hline Sugar & $55.1 \pm 10.6^{*}$ & \\
\hline
\end{tabular}

Note: $*$ means a discrepancy is statistically authentic $(p<0.05)$.

Table 5

Assessment of nutrients contents and caloric value of ration calculated as per menus and performed with individual weight method: comparative analysis of the results

\begin{tabular}{|l|c|c|c|}
\hline $\begin{array}{c}\text { Nutrient and } \\
\text { energetic value }\end{array}$ & $\begin{array}{c}\text { Calculated } \\
\text { as per menus }\end{array}$ & Weight method & $\begin{array}{c}\text { Validity of discrepancy } \\
(p \leq 0.05)\end{array}$ \\
\hline Proteins, g & $66.3 \pm 9.3^{*}$ & $54.2 \pm 10.4^{*}$ & $\mathbf{0 . 0 0 1}$ \\
\hline Fats, g & $62.5 \pm 9.8^{*}$ & $54.2 \pm 10.2^{*}$ & $\mathbf{0 . 0 0 9}$ \\
\hline Carbohydrates, g & $261.3 \pm 19.1^{*}$ & $205.9 \pm 17.5^{*}$ & $\mathbf{1 . 0 7}^{*} \mathbf{1 0}$ \\
\hline Caloric value, kcal & $1,864.5 \pm 134.1^{-11}$ & $1,522.8 \pm 111.9^{*}$ & $\mathbf{1 . 2 1}^{*} \mathbf{1 0}$ \\
\hline
\end{tabular}

Table 6 We examined children's provision with

Contents of certain vitamins and minerals in mg calculated as per menus and assessed with individual weight method: comparative analysis

\begin{tabular}{|c|c|c|c|}
\hline $\begin{array}{c}\text { Vitamins } \\
\text { and } \\
\text { minerals }\end{array}$ & $\begin{array}{c}\text { Calculated as } \\
\text { per menus }\end{array}$ & $\begin{array}{c}\text { Weight } \\
\text { method }\end{array}$ & $\begin{array}{c}\text { Validity of } \\
\text { discrepancy } \\
(p \leq 0,05)\end{array}$ \\
\hline $\mathrm{B} 1$ & $0.89 \pm 0.2^{*}$ & $0.72 \pm 0.2^{*}$ & $\mathbf{0 . 0 0 0 1}$ \\
\hline $\mathrm{B} 2$ & $1.0 \pm 0.3^{*}$ & $0.79 \pm 0.28^{*}$ & $\mathbf{0 . 0 0 0 1}$ \\
\hline $\mathrm{C}$ & $39.9 \pm 22.6$ & $35.0 \pm 21.8$ & 0.4 \\
\hline $\mathrm{Ca}$ & $784.3 \pm 95.7^{*}$ & $571.2 \pm 64.3^{*}$ & $\mathbf{2 . 0 9 * 1 0 ^ { - 1 0 }}$ \\
\hline $\mathrm{Fe}$ & $15.8 \pm 6.0^{*}$ & $13.5 \pm 6.3^{*}$ & $\mathbf{0 . 0 0 0 5}$ \\
\hline
\end{tabular}
vitamin and revealed that content of vitamin A in blood $\left(0.23 \pm 0.02 \mu \mathrm{g} / \mathrm{cm}^{3}\right)$ on average amounted to the physiological standard $\left(0.13-0,51 \mu \mathrm{g} / \mathrm{cm}^{3} ; p=0.68\right)$; however, it didn't exceed $0.12 \pm 0.01 \mu \mathrm{g} / \mathrm{cm}^{3}$ in $15 \%$ children and it was authentically lower that the standard $(p \leq 0.01)$. Contents of vitamin $\mathrm{E}$ $\left(0.37 \pm 0.03 \mu \mathrm{mol} / \mathrm{dm}^{3}\right)$ corresponded to the physiological standard $\left(0.15-0.87 \mu \mathrm{mol} / \mathrm{dm}^{3}\right.$, $p=0.46-0.87)$ in all examined children. But at the same time, provision with vitamin $\mathrm{C}$ didn't exceed $4.82 \pm 0.31 \mu \mathrm{g} / \mathrm{cm}^{3}$ and was close to the lower bound of the physiological standard (4.0-14.96 $\left.\mu \mathrm{g} / \mathrm{cm}^{3}, p=0.09\right)$; and it amounted 
to only $2.88 \pm 0.23 \mu \mathrm{g} / \mathrm{cm}^{3}$ in $75 \%$ children ( $p \leq 0.001$ against the physiologic standard). Average provision with vitamin $\mathrm{D}$ in the examined children reached $29.38 \pm 1.91 \mathrm{ng} / \mathrm{cm}^{3}$ (the physiological standard is $30-100 \mathrm{ng} / \mathrm{cm}^{3}$, $p=0.26$ ); however, it didn't exceed 23.16 \pm $\pm 1.13 \mathrm{ng} / \mathrm{cm}^{3}$ in $70 \%$ children and was lower than the physiological standard $(p=0.02)$. We revealed the same trend when analyzing contents of vitamins B group: as average group contents of vitamin $\mathrm{B}_{6}$ amounted to $6.48 \pm$ $\pm 0.58 \mu \mathrm{g} / \mathrm{dm}^{3}$ (the physiological standard is $\left.4.6-18.6 \mu \mathrm{g} / \mathrm{dm}^{3}, p=0.72\right) ; 60 \%$ children had only $3.46 \pm 0.20 \mu \mathrm{g} / \mathrm{dm}^{3}$ in their blood which was lower than the standard $(p=0.02)$. Contents of vitamin $\mathrm{B}_{12}$ amounted to only $166.35 \pm 24.49 \mathrm{pmol} / \mathrm{dm}^{3}$ (the standard being $\left.149-616 \mathrm{pmol} / \mathrm{dm}^{3}, p=0.68\right)$, however, it was even lower in $45 \%$ children (121.44 \pm $\pm 4.10 \mathrm{pmol} / \mathrm{dm}^{3}$ ) and didn't correspond to the physiological standard $(p=0.02)$. Overall, only $22.3 \%$ of the examined children had contents of basic vitamins (A, C, Д, E, B 6 и $\left.\mathrm{B}_{12}\right)$ in their blood that corresponded to the physiological standards. Selective deficiency of only one vitamin (basically it was vitamin $\mathrm{B}_{12}$ ) was detected in $37.8 \%$ children; combined deficiency of two vitamins, in $35.1 \%$ $\left(\mathrm{B}_{6}\right.$ and $\mathrm{B}_{12}$ in $28.2 \%$ children, and vitamins $\mathrm{B}_{12}$ and $\mathrm{D}$ in $6.9 \%$ ); a situation when a child had vitamin deficiency as per three vitamins $\left(\mathrm{B}_{6}, \mathrm{~B}_{12}\right.$ and $\left.\mathrm{D}\right)$ was rare and it was detected only in $4.8 \%$ of the examined children.

To establish what role chemical factors played in occurring vitamins deficiency among children, we assessed atmospheric air quality on the territory of the pre-school children facility and inside it. Our research revealed that average daily contents of formaldehyde in the atmospheric air amounted to $0.0051 \pm 0.0010 \mathrm{mg} / \mathrm{m}^{3}$ (MPCa.d. $=0.01 \mathrm{mg} / \mathrm{m}^{3}, p \leq 0.001$ ); ethylbenzene concentration was $\leq 0.002 \mathrm{mg} / \mathrm{m}^{3}$ (MPCa.d. = $\left.=0.02 \mathrm{mg} / \mathrm{m}^{3}, p \leq 0.001\right)$, and it didn't exceed any hygienic standards. However, phenol concentration $\left(0.0074 \pm 0.0018 \mathrm{mg} / \mathrm{m}^{3}\right.$; MPCa.d. $=$ $\left.=0.003 \mathrm{mg} / \mathrm{m}^{3}, p \leq 0.001\right)$ was 2.5 times higher than the permissible one. At the same time, our research revealed that formaldehyde and phenol concentrations in the air in playrooms reached $0.0270 \pm 0.0054 \mathrm{mg} / \mathrm{m}^{3}$ and $0.0169 \pm 0.0042$ $\mathrm{mg} / \mathrm{m}^{3}$ respectively, and it was higher than permissible levels $(p \leq 0.0001-0.001)$. We also detected ethylbenzene in the air inside playrooms $\left(0.0013 \pm 0.0003 \mathrm{mg} / \mathrm{m}^{3}\right)$, however, its concentration was lower than the maximum permissible one (MPCa.d. $=0.02 \mathrm{mg} / \mathrm{m}^{3} ; p=0.0001$ ). Chloroform occurred in water supplied to the pre-school children facility $(0.54 \pm 0.08 \mathrm{mg} / \mathrm{l})$ and its concentration amounted to 2.70 MPC $(p \leq 0.001)$; we also detected residual free/bound chlorine there in concentrations equal to $2.20 / 1.25 \mathrm{MPC}$ $(1.1 \pm 0.4 / 1.5 \pm 0.6 \mathrm{mg} / 1 ; p \leq 0.05)$.

Basing on the results obtained in our research, we divided all the children into two basic groups; out focus group was made up of 146 children with their provision with two or more vitamins being lower that the physiological standard; our reference group was made up of 42 children with their vitamin provision being equal to the physiological standards as per all the examined vitamins. Both groups were comparable as per their gender structure $(p=0.83)$. Our next step was to analyze concentrations of technogenic organic chemicals in blood and compare the results. Chemical and analytical research revealed that chloroform contents $(0.00099 \pm$ $\pm 0.00007 \mathrm{mg} / \mathrm{dm}^{3}$ in the focus group; and $0.00071 \pm 0.00006 \mathrm{mg} / \mathrm{dm}^{3}$ in the reference group) and ethylbenzene $(0.00021 \pm 0.00002$ $0.00013 \pm 0.00002 \mathrm{mg} / \mathrm{dm}^{3}$ accordingly) in children from both groups were authentically higher than the average regional contents $(p \leq 0.001)$, but concentrations of phenol $(0.0088 \pm 0.0012$ $\left.0.0055 \pm 0.0016 \quad \mathrm{mg} / \mathrm{dm}^{3}\right), \quad$ formaldehyde $\left(0.00393 \pm 0.00050-0.00202 \pm 0.00026 \mathrm{mg} / \mathrm{dm}^{3}\right)$ and tetrachloromethane $(0.000043 \pm 0.000005$ $0.000024 \pm 0.000007 \mathrm{mg} / \mathrm{dm}^{3}$ accordingly) were authentically lower $(p=0.03-0.001)$. At the same time, concentrations of the examined organic chemicals were authentically higher in children from the focus group than in those form the reference one $(p \leq 0.0001-0.001)$, and a number of children with concentrations of these chemicals in their blood being higher than the average regional level ( $81 \%$ as per phenol; $38 \%$ formaldehyde; $89 \%$, tetrachloromethane; $37 \%$, ethylbenzene) was 1.4-2.1 times greater than in the reference group $(38 \%, 22 \%, 65 \%, 18 \%$ respectively) ( $p=0.02-0.04)$. Children with insufficient vitamins provision ran 2.2-6.9 times 
higher relative risk of increased concentrations of organic chemicals in blood (phenol, formaldehyde, tetrachloromethane, and ethylbenzene) than children from the reference group $(\mathrm{OR}=$ $=2.18-6.89 ; \quad \mathrm{CI}=1.21-8.44 ; p=0.02-0.04)$. Besides, regression analysis allowed to detect a weak correlation between increased ethylbenzene and tetrachloromethane concentrations in blood and a decrease in vitamin $\mathrm{A}$ contents $\left(R^{2}=0.19-0.26 ; F=16.59-216.88\right.$; $p=0.02-0.04)$; an average correlation between increased formaldehyde and tetrachloromethane concentrations and a decrease in vitamin $\mathrm{B}_{6}$ contents $\left(R^{2}=0.39-0.48 ; \quad F=28.77-381.16\right.$; $p=0.001-0.002)$. We also detected an average correlation between increased phenol and formaldehyde concentrations in blood and lower contents of vitamin A $\left(R^{2}=0.39-0.46\right.$; $F=12.03-78.18 ; \quad p=0.01-0.02)$ and vita$\min \mathrm{C} \quad\left(R^{2}=0.37-0.44 ; \quad F=44.31-109.53\right.$; $p=0.01-0.02)$.

We examined oxidative and antioxidant processes and revealed that antioxidant protection in children from the focus group (glutathione peroxidase was equal to $34.44 \pm 5.29 \mathrm{ng} / \mathrm{cm}^{3}$; and superoxide dismutase, to $44.21 \pm 5.00 \mathrm{ng} / \mathrm{cm}^{3}$ ) was authentically lower than in children from the reference group (glutathione peroxidase was equal to $43.78 \pm 5.61 \mathrm{ng} / \mathrm{cm}^{3}$; and superoxide dismutase, to $59.39 \pm 7.00 \mathrm{ng} / \mathrm{cm}^{3}$, $p=0.001-0.014)$. Besides, antioxidant activity of blood serum amounted to $35.23 \pm 1.33 \%$ in children from the focus group while it was authentically higher in the reference group and amounted to $38.63 \pm 1.04 \%(p=0.01)$. We detected an average correlation between increased phenol, formaldehyde, and ethylbenzene concentrations in blood and a decrease in glutathione peroxidase $\left(R^{2}=0.38-0.41\right.$; $F=27.12-149.36 ; p=0.01-0.02)$ and superoxide dismutase $\left(R^{2}=0.47-0.53 ; F=31.74-238.11\right.$; $p=0.01-0.03$ ). Besides, we revealed a correlation between increased chloroform and tetrachloromethane contents in blood and a decrease in superoxide dismutase $\left(R^{2}=0.37-0.44\right.$; $F=12.98-273.25 ; p=0.001-0.02)$ and antioxidant activity of blood serum $\left(R^{2}=0.29-0.38\right.$; $F=19.09-88.24 ; p=0.01-0.02)$.

\section{Conclusions:}

1. Imbalanced nutrition and losses of nutrients caused by children not finishing their food up and not consuming the whole amount of dishes offered to them by the pre-school children facility lead to $20-30 \%$ decrease in quantity of exogenously introduced vitamins.

2. Environmental objects (atmospheric air, indoor air, drinking water supplied to pre-school children facilities) on industrially developed territories are contaminated with technogenic chemicals (formaldehyde, phenol, ethylbenzene, chloroform, residual free/bound chlorine), and it causes higher concentrations of these chemicals and their metabolites in children's blood.

3 . Increased concentrations of oxygencontaining aldehydes, aromatic hydrocarbons, and chlorine-organic compounds in children's blood make antioxidation enzymes less active and lead to lower contents of vitamins with antioxidant potential.

4. High prevalence of hypovitaminosis among pre-school children on industrially developed territories is caused by insufficient exogenous introduction of vitamins with food and effects of their metabolic absorption associated with increased concentrations of technogenic chemicals with pro-oxidant properties in biological media.

Funding. The research was not granted any sponsor support.

Conflict of interests. The authors state there is no any conflict of interests.

\section{References}

1. Kon' I.Ya. Detskaya (pediatricheskaya) dietologiya (nutritsiologiya): dostizheniya i problem [Children (pediatric) dietology (nutritiology): achievements and problems]. Pediatriya, 2012, vol. 91, no. 3, pp. 59-66 (in Russsian).

2. Kostantin Zh., Kugach V.V. Vitaminy i ikh rol' v organizme [Vitamins and their role in a body]. Vestnik farmatsii, 2006, vol. 32, no. 2, pp. 58-70 (in Russian).

3. Makarova A.Yu., Gorelova Zh.Yu., Sokolova S.B. Pitanie chasto boleyushchikh doshkol'nikov v organizovannykh kollektivakh i doma [Nutrition of pre-school children with poor health 
in pre-school children facilities and at home]. Praktika pediatra, 2010, March, April, pp. 46-51 (in Russian).

4. Kuchma V.R., Chernigov V.V. Monitoring of the modernization of childrens nutrition in educational institutions. Zdorov'e naseleniya $i$ sreda obitaniya, 2012, vol. 233, no. 8, pp. 7-10 (in Russian).

5. Chesnokov L.A., Kuz'micheva N.A., Krasikov S.I., Sharapova N.V., Mikhailova I.V. Some indicators of vitamin and antioxidatic status of inhabitans of region. Zdorov'e naseleniya i sreda obitaniya, 2013, vol. 243, no. 6, pp. 9-11 (in Russian).

6. Vrzhesinskaya O.A., Kodentsova V.M., Starovoitov M.V., Safronova A.I., Abramova T.V., Toboleva M.A., Aleshina I.V., Levchuk L.V. Assessment of vitamin supply in preschoolers. Rossiiskii vestnik perinatologii i pediatrii, 2017, vol. 62, no. 1, pp. 114-120. DOI: 10.21508/1027-4065-2017-62-1-114-120 (in Russian).

7. Ponomarenko, A.Yu. Problemy doshkol'nogo pitaniya v Rossii / A.Yu. Ponomarenko [Issues related to pre-school nutrition in Russia]. Rossiya v izmenyayushchemsya mire: Sbornik nauchnykh statei mezhdunarodnoi konferentsii. Kaliningrad, 2014, pp. 88-91 (in Russian).

8. Barman M., Murray F., Bernardi A.I., Sandberg A.-S., Sandin A. Nutritional impact on Immunological maturation during Childhood in relation to the Environment (NICE): A prospective birth cohort in Northern Sweden. BMJ Open, 2018, vol. 8, no. 10, e022013.

9. Zaitseva N.V., May I.V., Balashov S.Yu. Medical and biologic parameters of the population health state in conditions of inhabitancy complex natural-technogenic pollution. Izvestiya Samarskogo nauchnogo tsentra Rossiiskoi akademii nauk, 2009, vol. 11, no. 1-6, pp. 1144-1148 (in Russian).

10. Kuchma V.R., Milushkina O.Yu., Bokareva N.A., Detkov V.Yu., Fedotov D.M. Hygienic evaluation of the influence of environmental factors on the functional indices of schoolchildren. Gigiena i sanitariya, 2013, no. 5, pp. 91-94 (in Russian).

11. Gromova O.A., Torshin I.Yu., Pronin A.V. Kognitivnyi i neiroplasticheskii potentsial vitamina $\mathrm{D}$ u detei i podrostkov [Cognitive and neuroplastic potential of $\mathrm{D}$ vitamin in children and teenagers]. Farmateka, 2015, no. 6, pp. 15-24 (in Russian).

12. Kleshchina Yu.V., Eliseev Yu.Yu., Pavlov N.N. Specific features of the disturbeds nutrition in children. Zdorov'e naseleniya i sreda obitaniya, 2012, vol. 233, no. 8, pp. $20-22$ (in Russian).

13. Perevalov A.Ya., Lir D.N., Tapeshkina N.V. Hygienic assessment of children`s nutrition in preschool educational institutions. methodological approaches. Zdorov'e sem'i - 21 vek, 2014, vol. 4, no. 4, pp. 174-192 (in Russian).

14. Tapeshkina N.V. The structure of the nourishment of preschoolers during the weekend (short report). Voprosy pitaniya, 2014, vol. 83, no. 2, pp. 64-67 (in Russian).

15. Tkachuk E.A., Tarmaeva I.Yu., Tsyrenzhapova N.A., Boeva A.V. Characteristics of mineral composition of food used in primary schools. Kazanskii meditsinskii zhurnal, 2014, vol. 95, no. 3, pp. 434-438 (in Russian).

16. Kim M.-H., Yeon J.-Y. Status and needs of nutrition education for children's sugars intake reduction in elementary school. Journal of Nutrition and Health, 2018, vol. 51, no. 5, pp. 433-444.

17. Tilles-Tirkkonen T., Nuutinen O., Sinikallio S., Poutanen K., Karhunen L. Theory-informed nutrition education curriculum Tools For Feeling Good promotes healthy eating patterns among fifth grade pupils: cross-sectional study. Journal of Human Nutrition and Dietetics, 2018, vol. 31, no. 5, pp. 647-657.

18. Ivanova I.V., Chernaya N.L., Nikolaev A.G., Senyagina E.I. Specificities and stereotypes of nutrition of present-day schoolchildren in Yaroslavl. Voprosy detskoi dietologii, 2010, no. 1, pp. 25-28 (in Russian).

19. Nefedova L.V., Shvets A.A., Nefedov P.V. O sostoyanii sanitarno-epidemiologicheskogo blagopoluchiya doshkol'nykh obrazovatel'nykh uchrezhdenii g. Krasnodara [On sanitary-epidemiologic well-being of pre-school children facilities in Krasnodar]. Fundamental'nye issledovaniya, 2008, no. 6, pp. 66-67 (in Russian).

20. Semenova N.V., Kun O.A., Denisov A.P., Filippova E.D. Influence of level of sanitary and epidemiologic wellbeing on physical development of the children visiting preschool educational institutions. Mezhdunarodnyi zhurnal prikladnykh i fundamental'nykh issledovanii, 2015, no. 3, pp. 378-381 (in Russian).

Yambulatov A.M., Ustinova O.Yu. Hygienic assessment of environmental factors that cause insufficient provision with vitamins among pre-school children. Health Risk Analysis, 2018, no. 4, pp. 66-74. DOI: 10.21668/health.risk/2018.4.07.eng

Received: 28.10 .2018

Accepted: 14.12 .2018

Published: 30.12.2018 
UDC 338.45: 616.2: 613.6.02

DOI: $10.21668 /$ health.risk/2018.4.08.eng

Read

online

\title{
GENETICALLY MODIFIED FOOD PRODUCTS: PECULIARITIES OF GENETIC IDENTIFICATION
}

\author{
G.F. Mukhammadiyeva ${ }^{1}$, D.O. Karimov ${ }^{1}$, O.V. Dolgikh ${ }^{2}$, A.V. Krivtsov ${ }^{2}$, A.A. Mazunina ${ }^{2}$ \\ ${ }^{1}$ Ufa Research Institute of Occupational Health and Human Ecology, 94 Stepan Kuvykin Str., Ufa, 450106, \\ Russian Federation \\ ${ }^{2}$ Federal Scientific Center for Medical and Preventive Health Risk Management Technologies, 82 Monastyrskaya Str., \\ Perm, 614045, Russian Federation
}

Our research goal was to perform a genetic analysis of food stuffs produced in Russia in order to determine whether genetically modified components, predominantly soya, occurred in them. We also set a task to draw up an optimal list of genetic modifiers for sausages and soya products; this list was to be applied as a tool for monitoring of undeclared GMO and for providing biological safety of food stuffs. We applied polymerase chain reaction in real-time mode to analyze certain food products (sausages and soya products); the analysis was to reveal genetically modified organisms. The task was to identify the following GMO genes: promoters (p35SCaMV, P-SSUAra, Ubil, ract1, hsp70, TA29 tobacco promoter), terminators (nos3, T-E9, T-g7, T-OCS), reporter genes (nptll, qHptFP308, bar, pat_10-P), bio-pesticides Bacillus Thuringensis (Bt) or Cry-toxins (CrylAb/Ac), reporter gene of $\beta$-glucuronidase (GUS-gene). Analysis of some sausage samples allowed us to identify the following GMO genes: CrylAb/Ac, P-FMV, P-nos, bar, gus_9-P, T-nos3, nptii, P-TA29, T-E9, T-g7, T-OCS. The research performed on food products revealed GMO in $56 \%$ of the analyzed sausage samples. Genetic modification of the analyzed food samples had its peculiarities; a set of identified genes that included promoter genes P-FMV, terminators (nos3, T-g7, T-OCS), CrylAb/Ac endotoxin, and a reporter of GMO bar was one of them. We recommend to use the following candidate genes for GMO contents in food products: Cry1Ab/Ac, P-FMV, P-nos, bar, gus_9-P, T-nos3, nptii, P-TA29, T-E9, T-g7, T-OCS. They all are evidence that genetic modifications took place and they all can be applied as marker genes for control over food products safety as per GMO contents criterion.

Key words: genetically modified organisms, genes, promoters, terminators, food products safety, polymerase chain reaction, DNA.

Nowadays genetically modified plants are grown in 28 countries; they are especially widely spread in the USA, Brazil, Argentina, India, and Canada. Soya, potato, corn, sugar beet, tomato, pumpkin, and rape are the most common cultures. Territories where genetically-modified plants are cultivated grow annually on average by $15-18 \%$. Every year more than 4,000 genetically modified cultures are tested in field tests. More than $60 \%$ of all the soya, $15 \%$ of all the potatoes, and $7 \%$ of all the corn produced in the world are genetically modified. Certain food products and dishes in the USA are at present produced only with genetic engineering technologies (for example, hamburgers, some salads, fried potatoes, etc.) [1-3].

In Russia transgenic cultures are not sown and grown for commercial use. There are only closed experimental fields that belong to various research centers. Some genetically modified cultures are grown in the

(C) Mukhammadiyeva G.F., Karimov D.O., Dolgikh O.V., Krivtsov A.V., Mazunina A.A., 2018

Guzel F. Mukhammadiyeva - Candidate of Biological Sciences, Head of the Molecular and Genetic Research Laboratory at Toxicology and Genetics Department (e-mail: ufniimt@mail.ru; tel.: +7 (347) 255-19-48; ORCID: https:// orcid.org/0000-0002-7456-4787).

Denis O. Karimov - Candidate of Medical Sciences, Head of the Department for Toxicology and Genetics (e-mail: karimovdo@gmail.com; tel.: + 7 (347) 255-19-48; ORCID: https://orcid.org/0000-0003-0039-6757).

Oleg V. Dolgikh - Doctor of Medical Sciences, Professor, Head of the Department for Immune-Biological Diagnostics (e-mail: oleg@fcrisk.ru; tel.: +7 (342) 236-39-30; ORCID: https://orcid.org/0000-0003-4860-3145).

Alexandr V. Krivtsov - Candidate of Medical Sciences, Head of the Immune-Genetics Laboratory (e-mail: oleg@fcrisk.ru; tel.: +7 (342) 236-39-30; ORCID: http://orcid.org/0000-0001-7986-0326).

Alena A. Mazunina - Junior Researcher at the Department for Immune-Biological Diagnostics (e-mail: oleg@fcrisk.ru; tel.: +7 (342) 236-39-30; ORCID: https://orcid.org/0000-0002-3579-4125). 
RF in order to test their biological safety; they are potatoes (Moscow and Moscow region, Tambov, Krasnodar, the Far East), soya (Krasnodar region), sugar beet (Moscow region, Tambov, Krasnodar region, the Far East), corn (Moscow region, Tambov, Krasnodar, the Far East). Transgenic potato is also grown to test various cultivars (in 18 regions), and transgenic sugar beet and soya are grown for further processing and use in Moscow region and on some other territories. As there is no ban on imports of transgenic food products into Russia and there is a considerable growth in their outputs in the world, such products are penetrating the Russian market in bigger and bigger quantities $[4,5]$.

A system of control over genetically modified organisms (GMO) existing in Russia is based on regulatory consequences detection (35S promoter and NOS terminator). However, genetic engineering development led to creation of the GMO that belong to the second generation and don't contain these regulatory consequences. Such cultures can potentially occur on the Russian food market and remain unidentified $[6,7]$.

It is vital to provide biological safety of food products, and to do this, it is necessary to identify genetically modified food sources that are not declared as well as GMO combinations. To develop an optimal diagnostic combination of genetic markers (test-systems) for each food product is a most significant task that needs to be solved for providing food products quality and safety. Real-time polymerase chain reaction is an efficient technique for nucleic acids analysis [8-12].

Our research goal was to perform genetic analysis of Russian food products quality in order to reveal possible occurrence of genetically modified components (predominantly soya) in them; to determine an optimal list of genetic markers for sausages and soya products that can help to monitor GMOs that are not declared and to provide food biological safety.
Data and methods. Overall, we analyzed 47 samples of food products that were sold in the Republic of Bashkortostan and Perm region trying to detect genes of both transgenic soya and non-transgenic one. Analyzed samples were mostly represented by sausage products and meat delicacies (45 samples) such as sausages (boiled, semismoked, and boiled-smoked ones), smoked products (ham and carbonade), pate. We also examined soya products (two samples): hard tofu and soya milk.

We quantitatively determined $35 \mathrm{~S}$ promoter of cauliflower mosaic virus in the genetically modified soya DNA; our determination included sampling and samples preparations; DNA extraction out of food products samples; DNA fragments amplification and hybridization-fluorescent detection that takes place directly during real-time polymerase chain reaction (PCR) with TaqMan probes.

In addition to quantitative determination of marker of cauliflower mosaic virus $35 \mathrm{~S}$ promoter we performed a qualitative real-time PCR for screening other genetic modification markers [13-20] that included ${ }^{1}$ :

- detection of promoters applied in plants transfection: p35SCaMV, Act1, Ubi1, hsp70, TA29 tobacco promoter; as a rule, these promoters are the most widely used by GMOs creators;

- detection of the following terminators: nos3, T-E9, T-g7, T-OCS;

- detection of the following reporter genes: nptll, hpt, bar, dhfr, epsps, cp4;

- detection of MARs.

DNA was extracted out of samples with "DNA-sorb-C" reagents kit (Rospotrebnadzor's Central Scientific Research Institute for Epidemiology, Moscow) aimed for DNA extraction out of clinical materials, food products, and animal forages.

Amplification was performed with "AmpliKvant GM soya-FL" reagents kit aimed for detecting the following DNA fragments:

${ }^{1}$ Marker genes in food products that are evidence of performed genetic modifications: Information and methodical letter No. 11132 dated December 14, 2017. - Perm: Rospotrebnadzor regional office in Perm region, 2017. 
a consequence of $35 \mathrm{~S}$ promoter of cauliflower mosaic virus (P-35S CamV) and endogenous control (soya EC), that is, a gene that is specific both for transgenic and non-transgenic soya. This approach allowed to detect soya DNA occurrence in an examined sample. Polymerase chain reaction was performed with Rotor-Gene Q device (Qiagen, Германия) and CFX96 Real Time System device with detection of reaction products in real time mode. To perform fluorescent detection of PCR products, we applied the following channels: FAM/Green - recombinant DNA of 35S promoter and JOE/Yellow soya gene (endogenous control).

According to GMO determination technique we simultaneously examined reference samples, a positive one (a sample with certain GM-content, soya line MON89788) and a negative one (a sample that was certainly without any GM-content).

Post-registration monitoring aimed at detecting GM-content included examination of documents issued for genetically modified sources (GMS), food products and control over GM-products marking.

Documents were examined via analyzing a list of GMS allowed for use in the RF and a list of GMS manufactured in the world in large quantities (the list includes 81 GMS, such as soya, corn, rape, potato, marrow, papaya, tomato, rice, sugar beet, muscat melon, flax, etc.). We controlled marking on each food product manufactured from GMS and containing more than $0.9 \%$ GMS components in its structure.
Results and discussion. We performed laboratory control of food products in order to accomplish qualitative and quantitative determination of GMS contents in accordance with the State Standards and $\mathrm{MG}^{2,3,4,5}$.

When we examined food products trying to identify genetically modified sources, we didn't reveal $35 \mathrm{~S}$ promoter of cauliflower mosaic virus in any sample. We detected nontransgenic soya in 38 out of 47 analyzed product samples; 5 out of 38 products samples didn't have any data on soya occurrence in their structure on a label.

Screening qualitative examinations of 16 food products (sausages, salami, summer sausage, servelat) revealed that some samples had genetically-modified ingredients (Figure).

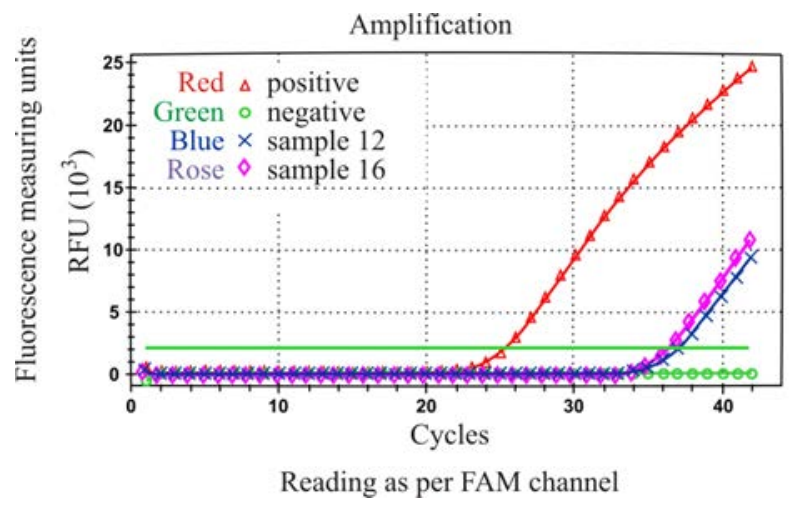

Figure. Polymerase chain reaction performed with CFX96 Real Time System device with detection of reaction products in real time mode. Amplification curves for 2 food products samples ("Bmketnaya" summer sausage and "Muskatnaya" boiled-smoked sausage) with P-FMV gene identification

\footnotetext{
${ }^{2}$ State Standard R 53244-2008. Food products. Analysis technique for detecting genetically modified organisms and products made of them. Techniques based on quantitative determination of nucleic acids [web-source] // KODEKS: an electronic fund of legal and reference documentation. - URL: http:// http://docs.cntd.ru/document/1200073607 (date of visit August 21, 2018).

${ }^{3}$ State Standard R ISO 21571-2014. Food products. Analysis technique for detecting genetically modified organisms and products made of them. Nucleic acid extraction [web-source] // KODEKS: an electronic fund of legal and reference documentation. - URL: http://docs.cntd.ru/document/1200114752 (date of visit August 15, 2018).

${ }^{4}$ MG 4.2.2304-07. Techniques for identification and quantitative determination of vegetable genetically modified organisms [web-source] // KODEKS: an electronic fund of legal and reference documentation. - URL: http://docs.cntd.ru/document/437120957 (date of visit August 06, 2018).

${ }^{5}$ MG 4.2.3390-16. Detection and identification of vegetable GMO with polymerase chain reaction in a matrix format [web-source] // KODEKS: an electronic fund of legal and reference documentation. - URL: http://docs.cntd.ru/document/456058289 (date of visit August 10, 2018).
} 
Table 1

Results of food products samples examination as per GMO contents

\begin{tabular}{|c|c|c|c|c|c|c|c|c|c|c|c|c|c|c|c|c|c|c|}
\hline $\begin{array}{c}\text { Samples } \\
\text { No. }\end{array}$ & $\begin{array}{l}\text { CaMV } \\
\text { P-35S }\end{array}$ & $\begin{array}{l}\text { CrylAb/ } \\
\text { Ac gene }\end{array}$ & P-FMV & P-nos & T-nos & bar & FMV34S & gus_9-P & qHptFP308 & NOS3-Taq & nptii & P-ract & P-SSuAra & P-TA29 & pat_10-P & T-E9 & T-g7 & T-OCS \\
\hline 1 & neg & neg & neg & neg & neg & neg & neg & neg & neg & neg & neg & neg & neg & neg & neg & neg & neg & neg \\
\hline 2 & neg & neg & neg & neg & neg & neg & neg & neg & neg & + & neg & neg & neg & neg & neg & neg & neg & neg \\
\hline 3 & neg & neg & neg & neg & neg & neg & neg & neg & neg & neg & neg & neg & neg & neg & neg & neg & neg & neg \\
\hline 4 & neg & neg & + & neg & neg & neg & neg & neg & neg & neg & + & neg & neg & neg & neg & neg & neg & neg \\
\hline 5 & neg & neg & neg & neg & neg & neg & neg & neg & neg & neg & neg & neg & neg & neg & neg & neg & neg & neg \\
\hline 6 & neg & + & neg & neg & neg & neg & neg & neg & neg & neg & neg & neg & neg & neg & neg & neg & neg & neg \\
\hline 7 & neg & neg & neg & neg & neg & neg & neg & neg & neg & neg & neg & neg & neg & neg & neg & neg & neg & neg \\
\hline 8 & neg & neg & neg & neg & neg & neg & neg & neg & neg & neg & neg & neg & neg & neg & neg & neg & neg & neg \\
\hline 9 & neg & neg & neg & neg & neg & neg & neg & neg & neg & neg & neg & neg & neg & neg & neg & neg & neg & neg \\
\hline 10 & neg & neg & neg & neg & neg & neg & neg & neg & neg & neg & neg & neg & neg & neg & neg & neg & neg & neg \\
\hline 11 & neg & + & neg & neg & neg & + & neg & neg & neg & neg & neg & neg & neg & neg & neg & neg & + & neg \\
\hline 12 & neg & neg & + & + & neg & neg & neg & neg & neg & + & neg & neg & neg & neg & neg & neg & neg & neg \\
\hline 13 & neg & neg & neg & neg & neg & neg & neg & neg & neg & + & neg & neg & neg & neg & neg & + & + & neg \\
\hline 14 & neg & neg & neg & neg & neg & + & neg & neg & neg & neg & neg & neg & neg & neg & neg & neg & neg & neg \\
\hline 15 & neg & neg & neg & neg & neg & neg & neg & neg & neg & neg & neg & neg & neg & + & neg & neg & neg & neg \\
\hline 16 & neg & neg & + & neg & neg & neg & neg & + & neg & neg & neg & neg & neg & neg & neg & neg & neg & neg \\
\hline $\mathrm{K}+$ & + & + & + & + & + & + & + & + & + & + & + & + & + & + & + & + & + & + \\
\hline K- & neg & neg & neg & neg & neg & neg & neg & neg & neg & neg & neg & neg & neg & neg & neg & neg & neg & neg \\
\hline
\end{tabular}

Our analysis of 16 food products samples, mostly variable sausages (Table 1), was aimed at identifying the following GMO genes: promoters (p35SCaMV, P-SSuAra, Ubi1, ract1, hsp70, tobacco TA29), terminators (nos3, T-E9, T-g7, T-OCS), reporter genes (nptll, qHptFP308, bar, pat_10-P), biopesticides genes Bacillus Thuringensis (Bt) or Cry-toxins (CrylAb/Ac), reporter gene of $\beta$-glucuronidase (GUS-gene); we revealed their absence in 7 analyzed food products samples against positive and negative reference samples. However, 9 sausage samples contained various GMO genes combinations such as Cry $1 \mathrm{Ab} / \mathrm{Ac}$, P-FMV, P-nos, bar, gus_9-P, T-nos3, nptii, P-TA29, T-E9, T-g7, T-OCS.

Conclusions. Our research didn't reveal any genetically modified soya as per a marker of $35 \mathrm{~S}$ promoter of cauliflower mosaic virus in food products. But at the same time we detected that a declared product structure of 5 sausage samples was false. Soya protein detected in their samples proves these food products have been falsified.
Post-registration monitoring aimed at GM-raw materials detection revealed occurrence of GMO markers that were not regulated in documents on standardization in $56 \%$ of analyzed sausage samples. Analysis of sausage samples allowed to identify candidate genes of genetically modified organisms, namely P-FMV promoter, terminators (nos3, T-g7, $\mathrm{T}-\mathrm{OCS}), \mathrm{Cry} 1 \mathrm{Ab} / \mathrm{Ac}$ endotoxin, bar reporter.

Such genes as Cry1Ab/Ac, P-FMV, P-nos, bar, gus_9-P, T-nos3, nptii, P-TA29, T-E9, T-g7, T-OCS can serve as an evidence that products containing them have been genetically modified. Genetic analysis of quality performed for products manufactured in Russia and aimed at detecting genetically modified components in them allows to recommend these genes to be applied as maker genes for control and providing food products safety as per GMO contents criterion.

Funding. The research was not granted any sponsor support.

Conflict of interests. The authors state there is no any conflict of interests. 


\section{References}

1. Bawa A.S., Anilakumar K.R. Genetically modified foods: safety, risks and public concerns-a review. J Food Sci. Technol., 2013, vol. 50, no. 6, pp. 1035-1046. DOI: 10.1007/s13197-012-0899-1

2. Wu Y., Li J., Wang Y., Li X., Li Y., Zhu L., Li J., Wu G. Development and application of a general plasmid reference material for GMO screening. Plasmid, 2016, vol. 87-88, pp. 28-36. DOI: 10.1016/j.plasmid.2016.08.001

3. James C. Global Status of Commercialized Biotech/GM Crops: 2014. ISAAA Brief. ISAAA: Ithaca, NY, 2014, no. 49, pp. 10-15.

4. Donnik I.M., Voronin B.A. Legal regulation of genetic engineering in agriculture in the Russian Federation. Agrarnyi vestnik Urala, 2017, vol. 156, no. 2, pp. 4 (in Russian).

5. Muratov A.A., Moskovenko N.V., Tikhonov S.L., Tikhonova N.V., Kurdyumov A.V. Normativno-pravovye aspekty regulirovaniya geneticheski modifitsirovannykh produktov na territorii Tamozhennogo soyuza [Regulatory aspects of the regulation of genetically modified products in the territory of the Customs Union]. Agroprodovol'stvennaya politika Rossii, 2017, vol. 63, no. 3, pp. 78-83 (in Russian).

6. Tutel'yan V.A. Obespechenie bezopasnosti genno-inzhenerno-modifitsirovannykh organizmov dlya proizvodstva pishchevykh produktov [Ensuring the safety of genetically engineered and modified organisms for food production]. Vestnik Rossiiskoi akademii nauk, 2017, vol. 87, no. 4, pp. 342-347. DOI: 10.7868/S0869587317040090 (in Russian).

7. Tyshko N.V. Control over genetically-modified sources of plant origin in food: scientific basis and methodical maintenance. Voprosy pitaniya, 2017, vol. 86, no. 5, pp. 29-33 (in Russian).

8. Chernysheva O.N., Sorokina E.Yu. Analytical methods for control of foodstuffs made from bioengineered plants. Voprosy pitaniya, 2013, vol. 82, no. 3, pp. 53-60 (in Russian).

9. Zaitseva N.V., Ulanova T.S., Dolgikh O.V., Nurislamova T.V., Mal'tseva O.A. Diagnostics of Early Changes in the Immune System Due to Low Concentration of N-Nitrosamines in the Blood. Bull Exp Biol Med., 2018, vol. 164, no. 3, P. 334-338. DOI: 10.1007/s10517-018-3984-2

10. Gerdes L., Busch U., Pecoraro S. GMOfinder - a GMO screening database. Food Analytical Methods, 2012, vol. 5, no. 6, pp. 1368-1376. DOI: 10.1007/s12161-012-9378-6

11. Morisset D., Novak P.K., Zupanič D., Gruden K., Lavrač N., Žel J. GMOseek: a user friendly tool for optimized GMO testing. BMC Bioinformatics, 2014, vol. 15, no. 1, pp. 258. DOI: 10.1186/1471-2105-15-258

12. Angers-Loustau A., Petrillo M., Bonfini L., Gatto F., Rosa S., Patak A., Kreysa J. JRC GMOMatrix: a web application to support Genetically Modified Organismsdetection strategies. BMC Bioinformatics, 2014, vol. 15, no. 1, pp. 417. DOI: 10.1186/s12859-014-0417-8

13. Alasaad N., Alzubi H., Kader A.A. Data in support of the detection of genetically modified organisms (GMOs) in food and feed samples. Data Brief, 2016, vol. 7, pp. 243-252. DOI: 10.1016/j.dib.2016.02.035

14. Debode F., Janssen E., Berben G. Development of 10 new screening PCR assays for GMO detection targeting promoters (pFMV, pNOS, pSSuAra, pTA29, pUbi, pRice actin) and terminators (t35S, tE9, tOCS, tg7). Eur Food Res Technol., 2013, vol. 236, no. 4, pp. 659-669. DOI: $10.1007 / \mathrm{s} 00217-013-1921-1$

15. Debode F., Janssen E., Bragard C., Berben G. Detection by real-time PCR and pyrosequencing of the cry $1 \mathrm{Ab}$ and cry $1 \mathrm{Ac}$ genes introduced in genetically modified (GM) constructs. Food Addit Contam Part A Chem Anal Control Expo Risk Assess, 2017, vol. 34, no. 8, pp. 1398-1409. DOI: 10.1080/19440049.2017.1317925

16. Dörries H.H., Remus I., Grönewald A., Grönewald C., Berghof-Jäger K. Development of a qualitative, multiplex real-time PCR kit for screening of genetically modified organisms (GMOs). Anal. Bioanal Chem., 2010, vol. 396, no. 6, pp. 2043-2054. DOI: 10.1007/s00216-009-3149-2

17. Gu K., Mao H., Yin Z. Production of marker-free transgenic Jatropha curcas expressing hybrid Bacillus thuringiensis $\delta$-endotoxin $\mathrm{Cry} 1 \mathrm{Ab} / 1 \mathrm{Ac}$ for resistance to larvae of tortrix moth (Archips micaceanus). Biotechnol Biofuels, 2014, vol. 7, pp. 68. DOI: 10.1186/1754-6834-7-68 
18. Randhawa G.J., Singh M. Multiplex, construct-specific, and real-time PCR-based analytical methods for Bt rice with cry1Ac gene. J. AOAC Int., 2012, vol. 95, no. 1, pp. 186-194.

19. Hernandez-Rodriguez C.S., Hernandez-Martinez P., Van Rie J., Escriche B., Ferre J. Shared midgut binding sites for Cry1A.105, Cry1Aa, Cry1Ab, Cry1Ac and Cry1Fa proteins from Bacillus thuringiensis in two important corn pests, Ostrinia nubilalis and Spodoptera frugiperda. PLoS One, 2013, vol. 8, no. 7, pp. e68164. DOI: 10.1371/journal.pone.0068164

20. Bahrdt C., Krech A.B., Wurz A., Wulff D. Validation of a newly developed hexaplex real-time PCR assay for screening for presence of GMOs in food, feed and seed. Anal Bioanal Chem., 2010, vol. 396, no. 6, pp. 2103-2112. DOI: 10.1007/s00216-009-3380-x

Mukhammadiyeva G.F., Karimov D.O., Dolgikh O.V., Krivtsov A.V., Mazunina A.A. Genetically modified food products: peculiarities of genetic identification. Health Risk Analysis, 2018, no. 4, pp. 75-80. DOI: 10.21668/health.risk/2018.4.08.eng

Received: 19.09 .2018

Accepted:

Published: 30.12.2018 
UDC 546.175: 351.773.1: 641.31

DOI: $10.21668 /$ health.risk/2018.4.09.eng

Read

online

\title{
ASSESSMENT OF RISKS CAUSED BY IMPACTS EXERTED ON A HUMAN BODY BY NITRATES CONTAINED IN FOOD PRODUCTS
}

\author{
I.P. Saldan, O.I. Shved, B.A. Balandovich, A.S. Nagornyak, O.N. Mazko, O.G. Makarova, \\ S.P. Filippova, O.V. Zhukova, N.Yu. Potseluev
}

Altai State Medical University, 40 Lenina avenue, Barnaul, 656038, Russian Federation

Food products contamination with xenobiotics of various genesis exerts negative influence on population health. According to multiple research performed on various territories in Russia, nitrates are basic contaminants occurring in food products and they make a considerable contribution into higher morbidity with specific nosologic forms, notably pathologies which are primarily caused by factors related to nutrition.

The paper focuses on analysis of laboratory research data on nitrates concentrations in food products; the data were collected in Altai region and they are taken from research reports issued by certified test laboratories. The authors also performed their own laboratory research at the Institute for Occupational Hygiene and Industrial Ecology of the RF Public Healthcare Ministry; it allowed to conclude that increased nitrates contents in food products were a vital issue which requires further examination and research performed with high precision laboratory research techniques.

We assessed hazard quotients (HQ) for nitrates occurring in vegetables and melons, individual carcinogenic risks (ICR), and population carcinogenic risks (PCR). Our hygienic assessment of nitrates concentrations in food products allowed us to reveal boundaries of risk properties variability.

It is necessary to work out recommendations how to reduce exposure of Altai region population to nitrates and to give grounds for priority approaches to administrative decision-making aimed at lowering population risks caused by consumption of nitrates-contaminated food products.

Key words: hygienic assessment, contamination with nitrates, monitoring, safety, food products quality, risk assessment.

\section{Introduction.}

To provide food safety for population in our country is a basic task which authorities in any region in the RF should solve. Altai region nowadays is a major producer and supplier of vegetable and animal food products both for its own population and people living in other regions; some products are also exported to the nearest countries. And as free economic zones such as the Customs Union and the Eurasian Economic Union are developing rapidly, this task is becoming even more significant.
Some hygienic problems are still to be solved in Altay region; for example, problems related to preventing various xenobiotics, including nitrates, from penetrating into food products at all the stages in their manufacturing, distribution, and storage. There are no well developed approaches to efficient population health preservation via more rational and optimal nutrition.

As per data taken from various research and works, vegetables, melons, and potato are most likely to be contaminated with ni-

(c) Saldan I.P., Shved O.I., Balandovich B.A., Nagornyak A.S., Mazko O.N., Makarova O.G., Filippova S.P., Zhukova O.V., Potseluev N.Yu., 2018

Igor' P. Saldan - Doctor of Medical Sciences, Professor (e-mail: rector@agmu.ru; tel.: +7 (3852) 56-68-02).

Ol'ga I. Shved - post-graduate student (e-mail: laukhina_olga@mail.ru; tel.: +7 (3852) 56-69-36).

Boris A. Balandovich - Doctor of Medical Sciences, Professor (e-mail: dr.balandovich@mail.ru; tel.: +7 (3852) 56-69-95).

Aleksei S. Nagornyak - post-graduate student (e-mail: tezaurismosis@gmail.com; tel.: +7 (3852) 56-69-36).

Olesya N. Mazko - Candidate of Medical Sciences, Senior Researcher (e-mail: noemail@agmu.ru; tel.: +7 (3852) 66-99-27).

Olesya G. Makarova - Candidate of Medical Sciences, Senior Researcher (e-mail: noemail@agmu.ru; tel.: +7 (3852) 66-99-27).

Sof'ya P. Filippova - Candidate of Medical Sciences, Associate Professor (e-mail: sofya.filippova@mail.ru; tel.: +7 (3852) 56-69-36).

Ol'ga V. Zhukova - Candidate of Medical Sciences, Associate Professor (e-mail: oov-@mail.ru; tel.: +7 8 (3852) 56-69-36).

Nikolai Yu. Potseluev - Candidate of Medical Sciences, Associate Professor (e-mail: pocelueff@mail.ru; tel.: +7 (3852) 56-69-36). 
trates $^{1,2,3}[1-3]$. Nitrates penetrate a human body in excessive doses due to vast application of nitrogen fertilizers in contemporary vegetable cultivation and due to nitrate compounds applied in food industry as preservatives and food additives, and it exerts adverse effects on health ${ }^{2,3}[2-4]$. If we assess nitrates contamination of food products which are sold in Altai region, it will allow us to estimate their contents in consumed food products and will help to implement prevention activities aimed at reduction of nitrates concentrations in food products. It is known that when some nitrates (about 5-7\%) are contained in food products in quantities higher than allowable concentrations, they can convert into nitrites in the gastrointestinal tract; and it is nitrites that exert adverse effects on a person's body and his or her health ${ }^{1}[5,6]$. When nitrites penetrate human blood, they make for ferrous iron oxidizing into ferric one, and it results in occurrence of hemiglobin which is unable to bring oxygen to body organs and tissues. Food products are a major way for nitrates to penetrate a body; first of all, we can mention vegetable products here (up to $80 \%$ nitrates enter a body with vegetables, including potatoes, melons, and fruit). Besides, nitrate can penetrate a body with drinking water and with medications $[2,4,7]$.

Nitrates hold a specific place among chemicals which are carcinogenic in their essence. Some research proves that they are related to malignant neoplasms emergence in the gastrointestinal tract [7]. Nitrates and nitrites are known to be authentic factors which cause higher stomach cancer risk as per data provided by authors who focus on issues related to influence exerted by food factors on carcinogenesis [8-10]. Research results reveal a significant correlation between oncologic tumors frequency and total load with mineral fertilizers and, consequently, nitrates [11, 12].

As a rule, hygienic assessment of food products is performed in specialized certified laboratories which makes for high quality products which are safe for consumers being sold on markets. Hygienic assessment of food products is to verify their conformity with the Customs Union Technical Regulations. Research related to nitrates concentrations in food products is regularly performed in Altai region by relevant test laboratories.

So, nowadays it is vital to hygienically assess nitrates contamination of food products on Altai region territory and to calculate risks of carcinogenic and non-carcinogenic effects caused by consumption of such products.

Research goal. Our goal was to assess nitrates contamination of food products manufactured and sold on Altai region territory and to assess risks related to consumption of such products by population in order to prevent adverse effects on a human body.

\section{Tasks.}

1. To assess nitrates contamination of food products produced and sold on Altai region territory via capillary electrophoresis.

2. To assess risks of emergence and growth in morbidity with certain nosologies under exposure to nitrates.

3. To work out scientifically grounded recommendations on improvement of laboratory control systems and prevention of alimentary-dependent diseases.

Data and methods. We took our data for retrospective analysis from official statistic reports provided by the Rospotrabnadzor re-

\footnotetext{
${ }^{1}$ MG 2.1.10.0062-12. Quantitative assessment of non-carcinogenic risk under exposure to chemicals based on evolution models design: methodical guidelines [Web-source]. - 2012. - P. 22. - URL: http://docs.cntd.ru/document/1200095225 (date of visit February 22, 2018).

${ }^{2}$ On sanitary-epidemiologic safety in the Russian Federation in 2013: State report [web-source]. - URL: http://rospotrebnadzor.ru/documents/details.php?ELEMENT_ID=1984 (date of visit February 22, 2018).

${ }^{3}$ On sanitary-epidemiologic safety in the Russian Federation in 2015: State report [web-source]. - URL: $\mathrm{http} / / /$ rospotrebnadzor.ru/documents/details.php?ELEMENT_ID=6851 (date of visit February 22, 2018).
} 
gional office in Altai region collected over 2011-2015.,3. More than 70,000 laboratory test results were analyzed; 13,000 out of them were analyzed in terms of their conformity to hygienic standards of nitrates contents in food products. All the data were statistically processed as per conventional techniques in Microsoft Excel 2013.

To determine nitrates contents in food products, we performed our research at the Institute for Occupational Hygiene and Industrial Ecology of Altai State Medical University; various vegetables such as cucumbers, tomatoes, cabbage, beetroot, onion, potatoes, and marrows brought from different Altai region territories (Barnaul, Ust'-Pristanskiy, Petropavlovskiy, and Zav'yalovskiy districts) were analyzed with the capillary electrophoresis technique [13-15]. This technique is based on separating components in a complicated mixture in a crystal capillary under exposure to applied electric field and it allows to examine micro-volumes of a sample. Confinement parameter (migration time) is a qualitative characteristics of a substance, and a peak height or square proportionate to a substance concentration is its quantitative characteristics [13]. Range of nitrate-ions measuring with capillary electrophoresis amounts to $5.0-50.0 \mathrm{mg} / \mathrm{l}$, a relative measurement uncertainty here being equal to $10 \%$. It was the first time when this technique was applied to examine nitrates contents in food products in Altai region. 189 food products samples were examined with it; they were chosen as research objects within scientific research NIR No. 02-18 planned in accordance with a working program for a postgraduate student training and research schedules approved in the Institute for Occupational Hygiene and Industrial Ecology of Altai State Medical University.
Carcinogenic risk caused by exposure to nitrates was assessed as per the Guidelines on assessment of population health risks under exposure to chemicals which pollute the environment ${ }^{4}$. We took average food products consumption in the region as our basic scenario. Consumption parameters were determined according to official data provided by the Federal Statistic Service, to be exact, its regional offices in Altai region and Altai Republic [16]. We calculated average annual consumption of each product per 1 person. A body weight of an adult man was considered to be equal to $70 \mathrm{~kg}$. Average daily nitrates doses were calculated as per average values for nitrates contents in examined food products.

We calculated individual carcinogenic risk with a modified exponential model ${ }^{2,3,5}$ $[5,7]$ :

$$
I C R=\exp \left(1,44 \cdot 10^{-7} K\right)^{-1}
$$

where

ICR is individual carcinogenic risk;

$\mathrm{K}$ is a quantity of nitrates which penetrated a body, mg/person/day.

Population carcinogenic risk was calculated as per a conventional technique [7]:

$$
P C R=I C R \cdot P O P,
$$

where

PCR is population carcinogenic risk;

POP is a number of people in an examined population, people.

To assess non-carcinogenic risks, we applied a hazard quotient (HQ) ${ }^{1}$ [7] and a mathematical model ${ }^{2,3}[5,7]$ :

$$
\Delta R=0,00052\left\langle\frac{1}{1+e^{-(-6,89+0,04 K)}}-\frac{1}{1+e^{-(-6,89+0,04 \cdot 1,6)}}\right\rangle,
$$

where $\Delta R$ is a non-carcinogenic risk growth.

${ }^{4} \mathrm{P}$ 2.2.1.10.1920-04. Guidelines on assessment of population health risks under exposure to chemicals which pollute the environment. - M.: Federal Center for State Sanitary and Epidemiologic Surveillance of the RF Public Healthcare Ministry, 2004. - $143 \mathrm{p}$.

${ }^{5}$ MY 2.3.7.2519-09 Determination of exposure and assessment of population health risks caused by chemical contaminants contents in food products. Methodical guidelines. - M.: Rospotrebnadzor's Federal Center for Hygiene and Epidemiology, 2010. -27 p. 
Results and discussion. We detected that experts from a test laboratory center at the Altai Center for Hygiene and Epidemiology examined 70,000 food products samples over 5 years, 2011-2015. The share of samples which didn't conform to hygienic standards varied from $0.1 \%$ to $2.0 \%$. In 2011 nitrates contents were higher than hygienic standards in $0.3 \%$ samples (vegetables, potatoes, and herbs). All the non-conforming samples were domestic products. In 2012 specific weight of samples not conforming to hygienic standards as per nitrates contents grew to $0.4 \%$. In 201314 fruit and vegetables samples out of 2,800 examined ones deviated from hygienic standards as per nitrates contents which accounted for $0.5 \%$ of the overall samples quantity. In 201428 out of 2,333 samples didn't conform to hygienic standards as per nitrates contents. Samples of fruit, vegetables, and melons deviated from standards most frequently. All the nonconforming samples taken in 2014 were domestic products. Specific weight of food products samples and food raw materials which didn't conform to hygienic standards amounted to $1.2 \%$ in 2014. In 20154 fruit and vegetables samples out of 2,289 examined ones deviated from hygienic standards as per nitrates contents which accounted for $0.2 \%, 3$.

We applied capillary electrophoresis technique in a laboratory at the Institute for Occupational Hygiene and Industrial Ecology to examine 189 samples of vegetables. Nitrates concentrations detected during food products examination ranged from $21.2 \pm 2.4 \mathrm{mg} / \mathrm{kg}$ to $1619.0 \pm 12.3 \mathrm{mg} / \mathrm{kg}$ of a product mass, average values here ranging from $46.0 \pm 1.7 \mathrm{mg} / \mathrm{kg}$ in marrows to $678.3 \pm 15.8 \mathrm{mg} / \mathrm{kg}$ in beetroot, as we can see in Figure 1.

As per statistic data provided by the Altai Regional Office of the Federal Statistic Service, vegetables, melons, potatoes, fruits and berries account for a considerable share of the overall food products consumption and are a significant part in Altai population food ration (Figure 2). They account for $31.6 \%$ of an aver- age statistical ration, share of potatoes being equal to $10.8 \%$; that of melons and vegetables, $12.4 \%$.

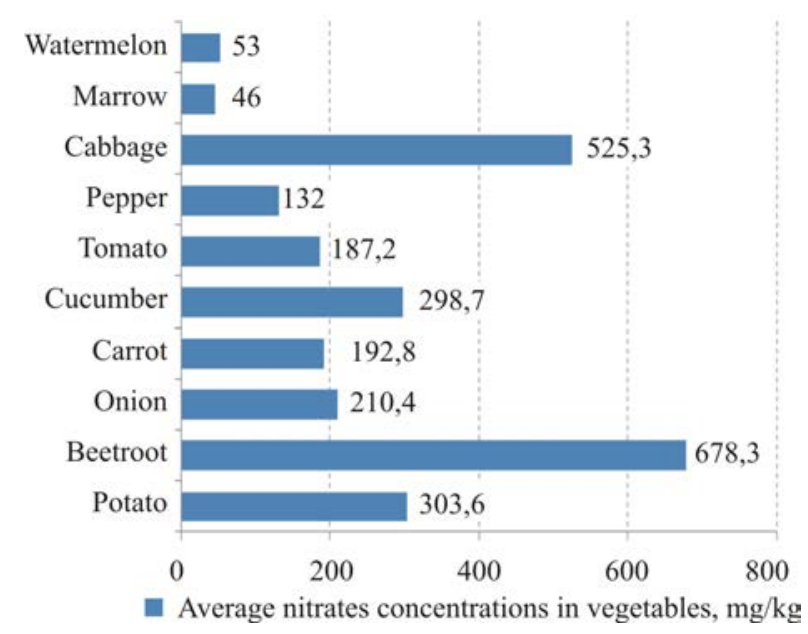

Figure 1. Average nitrates concentrations in various vegetables

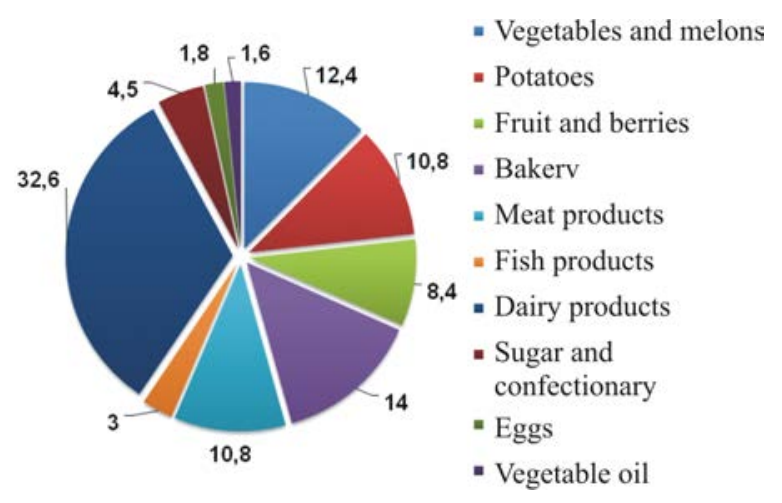

Figure 2. Shares of various food products in population ration in Altai region

We calculated average daily nitrates doses which penetrated a body with vegetables and potatoes; to do that, we determined average nitrates concentrations in examined vegetables (Figure 3). Average doses in which nitrates penetrated a body amounted to $170 \mathrm{mg}$ /day in Altai region $(77.4 \mathrm{mg} /$ day were introduced with potatoes; $92.6 \mathrm{mg} /$ day, with other vegetables).

We detected that cucumbers, onion, and potatoes made the greatest contribution into exposure to nitrates in Altai region. Excessive nitrates concentrations which were higher than MPC were detected in those products were 
registered most frequently; these concentrations also exceeded MPC greater than concentrations in any other products (Figure 4).

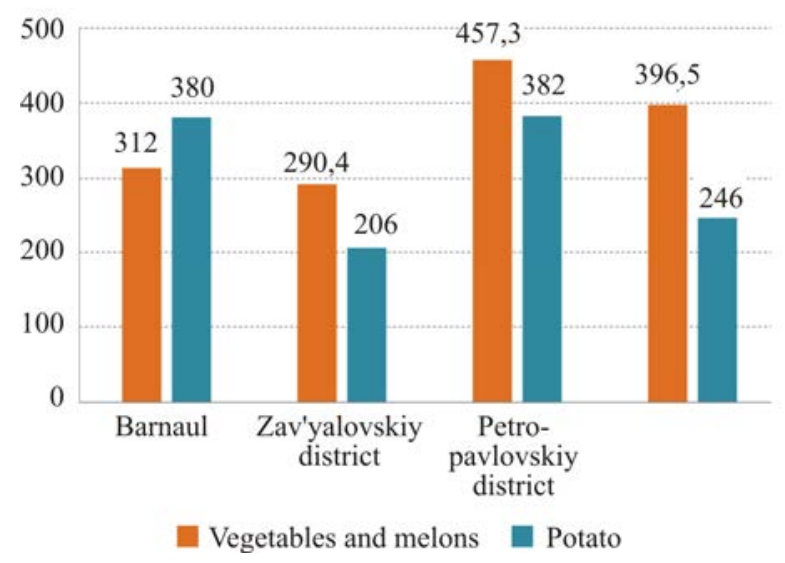

Figure 3. Average nitrates concentrations in food products, $\mathrm{mg} / \mathrm{kg}$

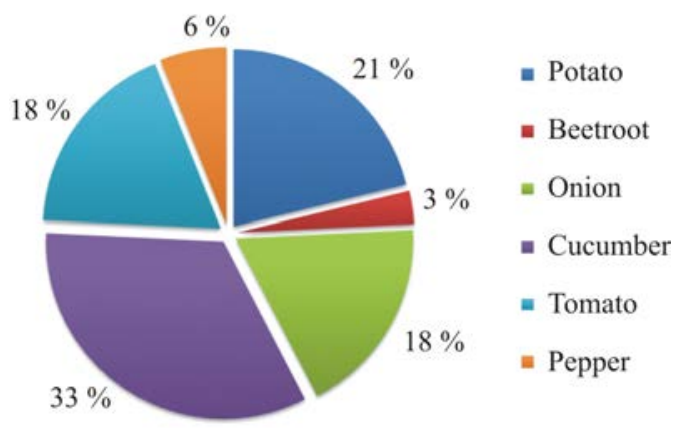

Figure 4. Specific weight of various vegetables in overall volume of products not conforming to hygienic standards as per nitrates concentration

Our calculation of individual carcinogenic risks (ICR) revealed that there was an additional probability that malignant neoplasms could emerge in a person during his or her life time. Carcinogenic risk could be estimated as low for all the examined territories in Altai region $\left(1 \cdot 10^{-6}-1 \cdot 10^{-4}\right)$; the maximum individual carcinogenic risk was detected on the examined territory, Petropavlovskiy region $\left(3.2 \cdot 10^{-5}\right)$. Though ICR is considered to be low, nevertheless, it is higher than permissible (which is lower than $1 \cdot 10^{-6}$ ); therefore, it makes a certain contribution into a probability that such pathology as a malignant neoplasm can emerge in an individual, as we can see on Figure 5.
Population carcinogenic risk shows a number of malignant neoplasms cases which occur in an examined population in addition to a background risk level. Individual and population carcinogenic risks show upper limit of possible carcinogenic risk for a period which is equal to an average life time of an individual (70 years) $[5,7]$.

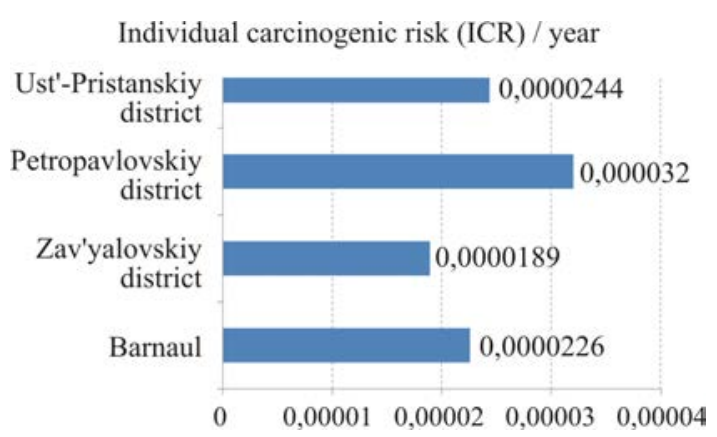

Figure 5. Individual carcinogenic risks caused by vegetables contamination with nitrates on different territories in Altai region

A carcinogenic process is a random one; it has long-term latent period; there are a lot of differences in age sensitivity to it; and a probability of death outcome for each individual is difficult to determine as it is time- and agedependent. Therefore, it is next to impossible to try and predict terms in which malignant neoplasms can occur even on the basis of all the available scientific data.

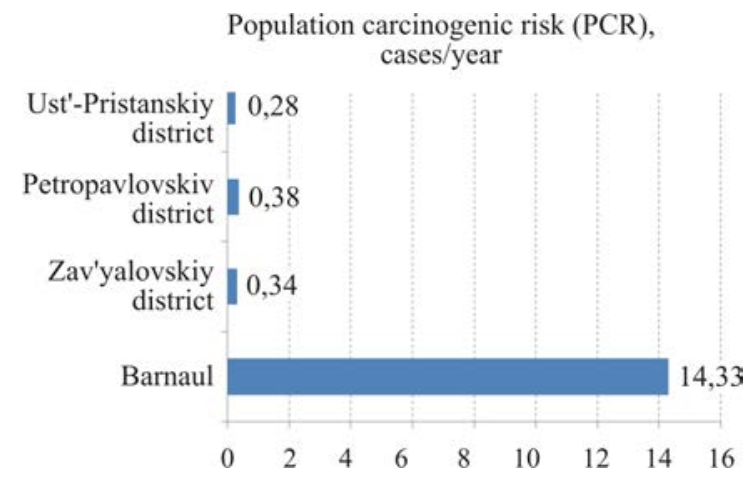

Figure 6. Population carcinogenic risks caused by exposure to nitrates on different territories in Altai region

As we can see from Figure 6, contamination of food products with nitrates makes a certain contribution into morbidity with ma- 
lignant neoplasms due to additional cases of the disease in population living on different territories in Altai region. 14 additional cases beyond the background level were detected in Barnaul; tentatively 1 additional case of the disease in three years was detected in Ust'Pristanskiy, Petropavlovskiy, and Zav'yalovskiy districts due to population number in these three regions being considerably smaller than in Barnaul (more than 20 times smaller).

Our estimation of hazard quotients for nitrates contained in fruit and vegetables revealed that their values were not higher than 1 ; it allowed us to conclude that effects exerted by nitrates on population health could be considered permissible provided that they entered a body in calculated doses during life time. Yet, should nitrates penetrate a human body in doses higher than calculated ones, HQ value can become higher than permissible one, and it will lead to greater hazardous influence exerted by nitrates and possible carcinogenic and non-carcinogenic effects in population living in the region. Thus, the hazard quotient in Petropavlovskiy region is already close to 1 , which means there is a greater possibility there that hazardous effects can occur when population consumes food products which contain calculated nitrates doses.

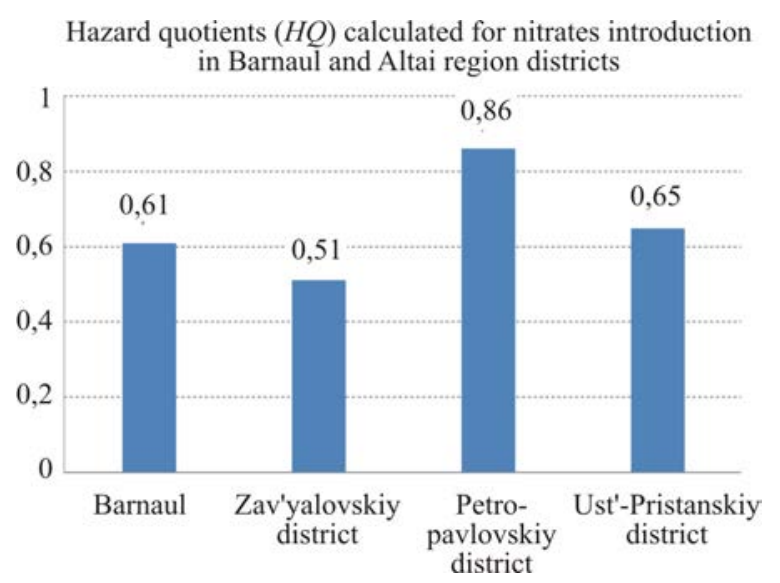

Figure 7. Hazard quotients (HQ) calculated for nitrates introduction in Barnaul and Altai region districts

\section{Conclusion.}

We analyzed available data obtained via laboratory research concerning nitrates contents in food products in Altai region. We detected that some vegetable products contained nitrates in concentrations higher than MPC. Excessive nitrates quantities were detected in vegetables (including potato and onion), herbs, melons and watermelons. Our own research revealed that such vegetables as cucumber, tomato, and onion, were most contaminated with nitrates.

Assessment of hazard quotients (HQ) for nitrates contained in vegetables and melons allows to consider influence exerted by nitrates on population health to be permissible provided that nitrates penetrate a body in calculated doses during life time. But at the same time, should nitrates penetrate a body in doses higher than calculated ones, it can cause HQ values become higher than permissible ones.

Individual carcinogenic risk (ICR) caused by nitrates concentrations in food products is estimated as low. ICR determined by nitrates contents in food products varies from $1.89 \cdot 10^{-5}$ to $3.2 \cdot 10^{-5}$. Such risk level doesn't require any additional measures aimed at its reduction; still, it is subject to selective periodic control as it makes a certain contribution into a probability of malignant neoplasms occurrence in population.

Value of population carcinogenic risk (PCR) caused by nitrates contents in food products allows us to assume that there is a possibility of $0.28-14.33$ malignant neoplasms cases occurring in population living on the examined territories which are additional to the background oncologic morbidity.

Funding. The research was not granted any sponsor support.

Conflict of interests. The authors state there is no any conflict of interests. 


\section{References}

1. Kislitsyna L.V. Otsenka soderzhaniya khimicheskikh kontaminant v produktakh pitaniya zhitelei Primorskogo kraya [Assessment of chemical contaminants concentrations in food products consumed by Primorskiy region population]. Zdorov'e. Meditsinskaya ekologiya. Nauka, 2011, vol. 46, no. 3, pp. 36-42 (in Russian).

2. Habermeyer M., Roth A., Guth S., Eisenbrand G., Diel P. [et al.] Nitrate and nitrite in the diet: how to assess their benefit and risk for human health. Molecular Nutrition and Food Research, 2015, vol. 59, no. 1, pp. 106-128.

3. Lucas Reijnders, Food safety, environmental improvement and economic efficiency in the Netherlands. British Food Journal, 2004, vol. 106, no. 5, pp. 388-405.

4. Poortmans J.R., Carpentier A., Gualano B. Nitrate supplementation and human exercise performance: too much of a good thing? Current Opinion in Clinical Nutrition and Metabolic Care, 2015, vol. 18, no. 6, pp. 599-604. DOI: 10.1097/MCO.0000000000000222.

5. Onishchenko G.G., Zaitseva N.V., May I.V. [et al.]. Analiz riska zdorov'yu v strategii gosudarstvennogo sotsial'no-ekonomicheskogo razvitiya: monografiya [Health risk analysis in the strategy of state social and economical development: monograph]. In: G.G. Onishchenko, N.V. Zaitseva eds. Moscow, Perm, Perm National Research Polytechnic University Publ., 2014, 738 p. (in Russian).

6. Ximenes M.I., Rath S., Reyes F.G. Polarographic determination of nitrate in vegetables. Talanta, 2000, vol. 51, no. 1, pp. 49-56.

7. Shur P.Z., Kir'yanov D.A., Atiskova N.G., Chigvintsev V.M., Khrushcheva E.V. Obosnovanie dopustimykh urovnei soderzhaniya nitratov $\mathrm{v}$ rastenievodcheskoi produktsii po kriteriyam riska zdorov'yu [Justificaion of acceptable nitrate levels in crop product using health risk criteria]. Zdorov'e naseleniya i sreda obitaniya, 2013, vol. 248, no. 11, pp. 47-48 (in Russian).

8. Lazarev V.V. Problema zabolevaemosti zlokachestvennymi novoobrazovaniyami v Omskoi oblasti [Morbidity with malignant neoplasms in Omsk region]. Bezopasnost' gorodskoi sredy: materialy mezhregional'noi nauchno-prakticheskoi konferentsii s mezhdunarodnym uchastiem [Urban environment safety: materials of theoretical and practical conference with international participation]. 2016, pp. 209-211(in Russian).

9. Deryagina V.P., Krivosheeva L.V., Savluchinskaya L.A., Golubeva I.S., Ryzhova N.I. Mekhanizmy realizatsii modifitsiruyushchego deistviya nitritov na kantserogenez [Modifying impacts exerted by nitrates on carcinogenesis: implementation mechanisms]. Novye informatsionnye tekhnologii v meditsine, biologii, farmakologii i ekologii: Materialy Mezhdunarodnoi konferentsii [New information technologies in medicine, biology, pharmacology and ecology: International conference materials]. In: E.L. Gloriozova ed. Gursuf-Yalta, 2017, pp. 185-191 (in Russian).

10. Boev V.M., Kuksanov V.F., Bystrykh V.V. Khimicheskie kantserogeny sredy obitaniya i zlokachestvennye novoobrazovaniya [Chemical carcinogens in the environment and malignant neoplasms]. Moscow, Meditsina Publ., 2002, 175 p. (in Russian).

11. Suleimanova N.D. Ekologicheskie aspekty zlokachestvennykh novoobrazovanii zhenskikh polovykh organov [Environmental aspects of malignant neoplasms of female genital organs]. Vestnik Dagestanskoi gosudarstvennoi meditsinskoi akademii, 2016, vol. 18, no. 1, pp. 75-79 (in Russian).

12. Davydov M., Demidov L., Polyakov B. Sovremennoe sostoyanie i problemy onkologii [Oncology: contemporary state and issues]. Vrach, 2006, no. 13, pp. 3-7 (in Russian).

13. Khomov Yu.A., Fomin A.N. Kapillyarnyi elektroforez kak vysokoeffektivnyi analiticheskii metod (obzor literatury) [Capillary electrophoresis as the high effective analytical method (review of the literature)]. Sovremennye problem nauki I obrazovaniya, 2012, no. 5, p. 349 (in Russian).

14. Velikinac I., Cudina O., Janković I., Agbaba D., Vladimirov S. Comparison of capillary zone electrophoresis and high performance liquid chromatography methods for quantitative determination of ketoconazole in drug formulations. Farmaco, 2004, vol. 59, no. 5, pp. 419-424. DOI: 10.1016/j.farmac.2003.11.019. 
15. Quaglia Giovanna M. [et al.]. Determination of fenticonazole and its impurities by capillary electrophoresis and high performance liquid chromatography. J. of High Resolution Chromatography, 2001, vol. 24, no. 5, pp. 392-396.

16. Potreblenie produktov pitaniya $\mathrm{v}$ domashnikh khozyaistvakh Altaiskogo kraya [Food products consumption in Altai region households]. Federal'naya sluzhba gosudarstvennoi statistiki po Altaiskomu krayu i Respublike Altai: Ofitsial'nyi sait. Available at: http://akstat.gks.ru/wps/wcm/connect/rosstat ts/ akstat/resources/929513804e9856abb99cbba638e2bbf1/\%D0\%9F\%D0\%BE\%D1\%82\%D1\%80.\%D0\% BF\%D1\%80\%D0\%BE\%D0\%B4.\%D0\%BF\%D0\%B8\%D1\%82\%D0\%B0\%D0\%BD\%D0\%B8\%D1\%8F.h tm (10.02.2018) (in Russian).

Saldan I.P., Shved O.I., Balandovich B.A., Nagornyak A.S., Mazko O.N., Makarova O.G., Filippova S.P., Zhukova O.V., Potseluev N.Yu. Assessment of risks caused by impacts exerted on a human body by nitrates contained in food products. Health Risk Analysis, 2018, no. 2, pp. 81-88. DOI: 10.21668/health.risk/2018.4.09.eng

Received: 02.03 .2018

Accepted: 01.06.2018

Published: 30.12.2018 
UDC 616-053.2+613.2/.3: [614.31/638 (470.56)

DOI: $10.21668 /$ health.risk/2018.4.10.eng

\title{
RISK OF HEALTH DISORDERS IN CHILDREN CASUED BY CONSUMPTION OF CONTAMINATED FOOD PRODUCTS
}

\author{
A.G. Setko, J.K. Mryasova, A.V. Turin \\ Orenburg State Medical University, 6 Sovetskaya Str., Orenburg, 460000, Russian Federation
}

Prevalence of diseases related to chemical contamination of the environment, including food products, among various population group is still a vital issue. A child's body is the most sensitive to influences exerted by environmental contamination; deficiency of nutrients in a ration leads to a drastic increase in a risk of ecology-related health disorders. Our research goal was to hygienically assess safety of teenagers' and children's nutrition in Orenburg, taken in dynamics over 2007-2015, within risk assessment frameworks. Nutrition safety was assessed as per various food products groups. First of all, we focused on chemical contaminants; the priority ones that were identified included nitrates, heavy metals (lead, cadmium, mercury, arsenic, and copper), pesticides, chloramphenicol, and histamine. Laboratory analysis revealed the most contaminated products that included meat and meat products, milk and dairy products, fish and fish products, vegetative and animal oil. Dynamics taken over a long-term period allowed us to detect that a major contribution into a risk caused by chemical contamination was made by nitrates, mercury, cadmium, and arsenic. We determined non-carcinogenic hazards related to food products provided for nutrition in schools and pre-school children facilities; the first place belonged to impacts on the cardiovascular system, $H_{c v s}=4.99$; the second rank place was taken by impacts on the hormonal system, $H I_{\text {horm }}=4.56$; the third place belonged to impacts on the CNS, $H I_{c n s}=3.2$. Impacts on blood followed $\left(H I_{b l o o d}=3.18\right) ;$; they were followed by impacts on the immune system $\left(H I_{\text {immune }}=2.99\right)$, nervous system $\left(H I_{n e r v}=2.28\right)$, and kidneys $\left(H I_{\text {kidneys }}=2.28\right)$. When we assessed noncarcinogenic hazard indexes for nutrition outside children and teenagers facilities, we detected risks for the hormonal system $\left(H I_{\text {horm }}=2.8\right)$; $C N S\left(H I_{\text {cns }}=2.0\right)$; kidneys $\left(H I_{\text {kidneys }}=1.63\right)$; immune system $\left(H I_{\text {immune }}=1.58\right)$; reproductive system $\left(H I_{\text {repr }}=1.24\right)$; and the nervous system $\left(H I_{\text {nerv }}=1.17\right)$.

Total non-carcinogenic risk for critical organs and systems was assessed as "high" for the hormonal system (HI=7.4), CNS $(H I=5.2)$, and the cardiovascular system $(H I=5.8)$. Average non-carcinogenic risk was detected for the immune system $(H I=4.6)$ and the nervous system $(H I=3.5)$, for kidneys $(H I=3.9)$ and blood $(H I=3.6)$.

We detected changes in the microelement state of children and teenagers that were characterized with some parameters being higher than an average level in the country, namely as per lead contents (by $56 \%$ ), cadmium contents (by $87 \%$ ), mercury contents (by $30 \%$ ), and arsenic contents (by $23 \%$ ).

Key words: chemical contamination, health risk, children, nutrition safety, contaminants, non-carcinogenic risk.

Introduction. Nowadays quality and safety of food products are pressing issues and serious efforts are required to solve them, both by biochemists, microbiologists, and toxicologists, and by manufacturers and sanitary-epidemiologic authorities as well. As per data provided by the Federal Russian Institute of Nutrition, healthy nutrition can prevent up to $80 \%$ of cardiac infarctions, strokes, and diabetes [1, 2].

Food manufacturing technologies, chemistry, microbiology, and biotechnologies are constantly developing and it leads to creation of new food additives and GMOs that appear on the market in large quantities. And growing anthropogenic contamination of the environment calls for legal regulation performed by the state over relations in the sphere of providing food products safety and quality including sanitary-epidemiologic surveillance; when it is necessary, and especially when it concerns children nutrition, requirements to food products safety are to be toughened [3-8].

Nutrition is a key factor in preserving and improving population health; this postulate is

(C) Setko A.G., Mryasova J.K., Turin A.V., 2018

Andrey G. Setko - Doctor of Medical Sciences, Professor, head of Department for Children's and Teenagers' Hygiene and Nutrition and Occupational Hygiene (e-mail: a_isetko@mail.ru; tel.: +7 (3532) 50-06-06 (ext. 401); ORCID: https://orcid.org/0000-0002-4363-2169).

Jeanna K. Mryasova - full-time post-graduate student at the Department for Children and Teenagers Hygiene with Nutritional and Occupational Hygiene (e-mail: jane-very@mail.ru, tel.: +7 (3532) 50-06-06 (ext. 402)).

Alexander V. Turin - Candidate of Medical Sciences, Associate Professor at Department for DisastrousAccidents Medicine (e-mail: K GDiP@orgma.ru; tel.: +7 (3532) 50-06-06 (ext. 402); ORCID: https://orcid.org/0000-0002-5589-8116). 
fixed in the most significant state documents such as "The RF Food Security Doctrine" and "Fundamentals of the RF state policy in the sphere of healthy nutrition for a period up to 2020" [9]. Rospotrebnadzor presented the state viewpoint at the UN General Assembly on nutrition in September 2016 in New York: "when we solve issues related to sufficient and balanced nutrition, it is absolutely unacceptable to allow elevated health risks caused by microbiological and chemical contaminants in food products. Contemporary tools for risks assessment should give grounds for building up national strategies and plans aimed at fight against malnutrition in all its forms and at providing food safety and quality".

Special attention should be paid to the most vulnerable population groups, such as children and teenagers. A child body is highly sensitive to chemicals; multiple research proves that a share of children with various health disorders is substantially higher on urbanized territories. Recently there has been a negative trend related to increased burden of heavy metals $(\mathrm{Pb}, \mathrm{Cd}$, As, and $\mathrm{Hg})$ contained in food products on a child body [10-14]. Significant contamination of food products exerts negative impacts on proper functioning of systems in a growing child's body; it primarily influences the cardiovascular, hormonal, immune, nervous systems, and blood. Chemical contamination of food products exerts adverse impacts on children's physical development, causes strain in adaptation mechanisms and makes functional parameters go down [15-21].

Our research goal was to hygienically assess safety of basic food products used in nutrition provided for children and teenagers in Orenburg over 2007-2015 in terms of possible health risks that can be caused by them.

Data and methods. Safety of food products consumed by children and teenagers at their schools in Orenburg was assessed as per laboratory research data provided by Orenburg Regional Center for Hygiene and Epidemiology and according to MG 2.3.7.2125-06 "Social and hygienic monitoring. Chemical contamination of food raw materials and food products. Samples collection, processing, and analysis of parameters"1; experts checked whether food products conformed to standards fixed in the Customs Union Technical Regulations $^{2}$. Results of examinations performed on 5,106 food samples were analyzed in 8-year dynamics; all the samples were taken in Orenburg within scheduled inspections and examinations of food products safety. Non-carcinogenic risks caused by food products contaminated with chemicals was assessed according to the Guide R 2.1.10. 1920-04 "Guidelines on assessment of population health risk under exposure to chemicals which pollute environment ${ }^{3}$. Risk assessment was performed as per the complete chart and included four stages: hazard identification, assessment of exposure to chemicals, assessment of "dose response" relationship, and risk characteristics. Assessment of exposure assumed two exposure scenarios. The first scenario was aimed at assessing actual dose burdens borne by children at their schools, that is, it covered only food offered to children at educational establishments. The second scenario quantified exposure levels with determined concen-

\footnotetext{
${ }^{1}$ MG 2.3.7.2125-06. Social and hygienic monitoring. Chemical contamination of food raw materials and food products. samples collection, processing, and analysis of parameters [web-source] // KODEKS: an electronic fund of legal and reference documentation. - URL: http://docs.cntd.ru/document/1200048757 (date of visit June 16, 2018).

${ }^{2}$ CU TR 21/2011. On food products safety: The Customs Union Technical Regulations [web-source] // KODEKS: an electronic fund of legal and reference documentation. - URL: http://docs.cntd.ru/document/902320287 (date of visit June 16, 2018).

CU TR 033/2013. On safety of milk and dairy products: The Customs Union Technical Regulations [web-source] // KODEKS: an electronic fund of legal and reference documentation. - URL: http://docs.cntd.ru/document/499050562 (date of visit June 16, 2018).

CU TR 034/2013. On safety of meat and meat products: The Customs Union Technical Regulations [web-source] // KODEKS: an electronic fund of legal and reference documentation. - URL: http://docs.cntd.ru/document/499050564 (date of visit June 16, 2018).

${ }^{3} \mathrm{P}$ 2.1.10.1920-04. Guidelines on assessment of population health risk under exposure to chemicals which pollute environment. - M.: The Federal Center for the State Sanitary and Epidemiologic Surveillance of the RF Public Healthcare Ministry, 2004. $-143 \mathrm{P}$.
} 
trations and calculated doses of exposure to chemicals in food products sold in retail networks taking into account standard coefficients and calculation values as well as statistical data on consumption of basic food products. Risk characteristics for non-carcinogenic chemicals was calculated by comparing actual daily exposure (daily dose) with a reference dose or concentration; such characteristics also included calculating hazard quotient and hazard index that took into account impacts exerted by different chemicals on the same target systems and organs. When HQ (HI) was equal to 1 or lower it meant there was a negligible risk of hazardous impacts; when $\mathrm{HI}$ (HQ) was from 1 to 5, it meant a risk was average; when HI (HQ) was from 5 to 10 , a risk of non-carcinogenic effects was high.

Results and discussion. Food products contaminated with foreign chemicals can become a source of chronic contaminants accumulation in a body and lead to a decrease in quantities of essential substances due to oxidation. Such food products are actually hazardous as a growing child's body is extremely sensitive to penetration of abiogenous substances that produce adverse effects on a child's development and functioning of the most significant systems in a body, namely the immune, nervous, and genital ones. Nutrition safety was assessed as per 8 food products groups with such hazardous chemicals identified in them as nitrates, heavy metals $(\mathrm{Pb}, \mathrm{Cd}, \mathrm{Hg}$, $\mathrm{As}$, and $\mathrm{Cu})$, pesticides, chloramphenicol, and histamine.

We analyzed results of laboratory examinations and revealed that contamination levels differed in various food products groups. Thus, meat and meat products, milk and dairy products, fish and fish products, vegetable oil and butter were the most contaminated $(100 \%-$ $75 \%$ ); the next rank place belonged to fruit and vegetables, grain, sugar, and confectionary. The analysis allowed us to determine average daily doses of contaminants $(\mathrm{mg} / \mathrm{kg})$ consumed with food products and it substantiated assessment of non-carcinogenic risks for children's health.

According to the first exposure scenario, we assessed non-carcinoigenic risks caused by chemical contamination of food products consumed by children at their educational establishments. On average, 98-99\% children attending educational establishments in Orenburg were offered cooked meals and it allowed us to perform authentic assessment and minimize uncertainty errors.

We assessed non-carcinogenic risks caused by chemical contaminants consumed with food products in dynamics over a long period of time; the assessment results revealed that risk value as per priority contaminants was close to minimum over recent years $(\mathrm{HQ} \leq 1)$ (Figure 1). The greatest total noncarcinogenic hazard quotient was detected as per 1) nitrates that were mostly consumed with fruit, vegetables, meat, and meat products; 2) $\mathrm{Hg}$, mostly consumed with fish and fish products $(44 \%)$, fruit and vegetables $(22 \%)$, meat and meat products $(19 \%)$; 3$)$ As, mostly consumed with milk and dairy products, meat and meat products, fish and fish products $(43 \%, 23 \%$ and $18 \%$ respectively). The next rank place was taken by $\mathrm{Cd}$; this contaminant was mostly consumed with vegetable oil and butter, meat and meat products, fruit and vegetables $(45 \%, 29 \%$ and $13 \%$ respectively)

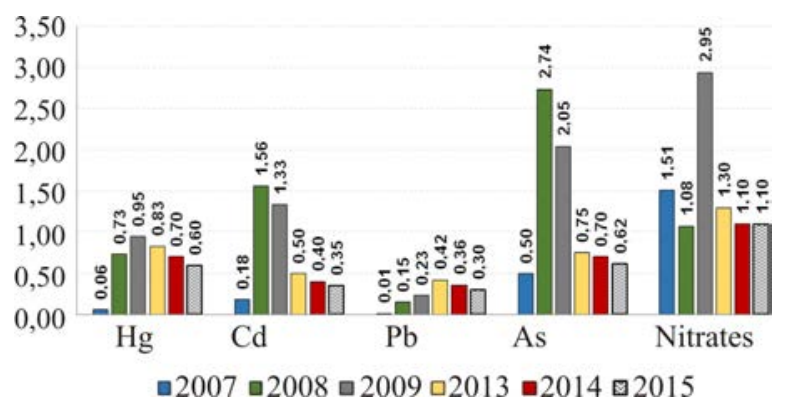

Figure 1. Dynamics of non-carcinogenic effects caused by contaminated food products consumed at educational establishments (HQ)

We calculated non-carcinogenic hazard indexes taking into account that different contaminants can exert their adverse impacts on the same target organs and systems. the greatest exposure risk was detected for the cardiovascular system $\left(H I_{\mathrm{cvs}}=4.99\right)$. The second rank place was taken by risk for the hormonal system $\left(H I_{\text {horm. }}=4.56\right)$; risk for the CNS took 
the third place $\left(H I_{\mathrm{cns}}=3.23\right)$. Risks for blood followed $\left(H I_{\text {blood }}=3.18\right)$; the next was risk for the immune system $\left(H I_{\text {immune }}=2.99\right)$, the nervous system (HInerv $=2.28)$, and kidneys $\left(H I_{\text {kidneys }}=2.28\right)$ (Figure 2$)$.

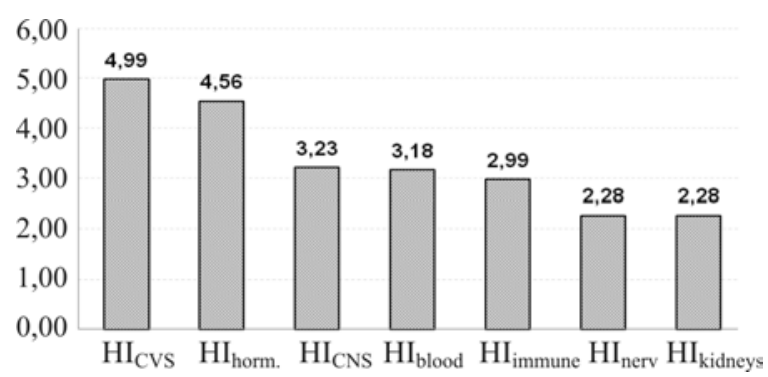

Figure 2. Total hazard indexes for critical organs and systems in a child's body calculated for children as per food consumed at their educational establishments $(H I)$

The second exposure scenario involved food consumed by children and teenagers beyond their educational establishments, that is, food consumed at home. Home meals satisfy from $40 \%$ to $60 \%$ of the overall daily need in nutrients and energy. In this scenario, exposure doses were calculated on the basis of examination results obtained for food products distributed through retail networks in the city, and safety and quality parameters as well; they were calculated as per a standard formula for calculating an average dose for food consumption in families with low middle incomes.

We assessed non-carcinogenic hazard indexes for meals consumed beyond educational establishments and detected that the first rank place belonged to risk of impacts on the hormonal system $\left(H I_{\text {horm. }}=2.8\right)$; the second one, risks for the CNS $\left(H I_{\mathrm{cns}}=2.0\right)$; the third one, risks to kidneys $\left(H I_{\text {kidneys }}=1.63\right)$; risks for other organs and systems followed (Figure 3). We should note that non-carcinogenic risks caused by meals consumed beyond educational establishments were 1.5-2 times lower than those caused by food consumed at such establishments.

Lower risks caused by consumption of chemicals with food products bought in retail outlets than those caused by food consumed at educational establishments are primarily ex- plained by poorer laboratory support provided for monitoring over quality and safety of food products; this poorer support doesn't allow to reduce errors of uncertainties in risk assessment. It is also confirmed by official statistic data on shares of food samples not conforming to hygienic standards as per chemical contaminants concentrations; they amounted to $0.64 \%$ in $2014,0.55 \%$ in 2015 , and $0.56 \%$ in 2016 in the RF in general, and to $0.1 \%, 0 \%$ and $0.06 \%$ in Orenburg respectively.

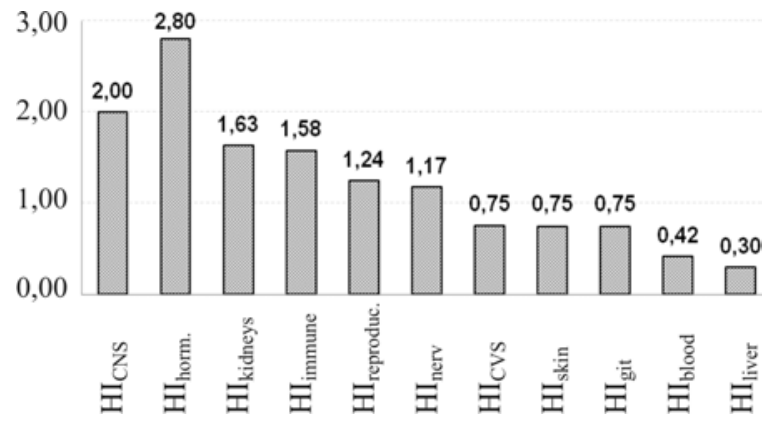

Figure 3. Total hazard indexes for critical organs and systems in a child's body calculated

for children as per food consumed beyond their educational establishments $(H I)$

At the next stage we assessed total noncarcinogenic risk for critical organs and systems caused by chemical contamination of food products, both consumed at educational establishments and distributed by retail networks in the city. We detected high risk for the hormonal system $(H I=7.4)$, the CNS $(H I=5.2)$, and the cardiovascular system $(H I=5.8)$. Average non-carcinogenic risks were detected for the immune system $(H I=4.6)$, the nervous system $(H I=35)$, kidneys $(H I=3.9)$, and blood $(H I=3.6)$ (Table).

There has been a growth in primary morbidity among children over the last 2-3 years at the population level; thus, morbidity with the circulatory system diseases has went up by $39.7 \%$; the nervous system diseases, by $24.3 \%$; neoplasms, by $8.9 \%$; injuries and intoxication, by $2 \%$; the respiratory system diseases, by $1.6 \%$; eye and its accessory apparatus diseases, by $1.3 \%$. Primary morbidity among teenagers has also grown as per several nosologies; morbidity with digestive organs 
Table

Risks of non-carcinogenic effects produced on children's health by chemicals consumed with food products

\begin{tabular}{|l|c|c|c|}
\hline $\begin{array}{c}\text { Critical organs } \\
\text { and systems }\end{array}$ & $\begin{array}{c}\text { Index of non-carcinogenic } \\
\text { hazard occurring beyond } \\
\text { educational establish- } \\
\text { ments } H I \text { (units) }\end{array}$ & $\begin{array}{c}\text { Index of non-carcinogenic } \\
\text { hazard occurring at educa- } \\
\text { tional establishments } H I \\
\text { (units) }\end{array}$ & $\begin{array}{c}\text { Total } \\
\text { non-carcinogenic } \\
\text { hazard index }(H I)\end{array}$ \\
\hline Central nervous system & 2.0 & 3.2 & 5.2 \\
\hline Hormonal system & 2.8 & 4.6 & 7.4 \\
\hline Kidneys & 1.6 & 2.3 & 3.9 \\
\hline Immune system & 1.6 & 3.0 & 4.6 \\
\hline Reproductive system & 1.2 & 0.0 & 1.2 \\
\hline Nervous system & 1.2 & 2.3 & 3.5 \\
\hline Cardiovascular system & 0.8 & 5.0 & 5.8 \\
\hline Skin & 0.8 & 0.0 & 0.8 \\
\hline Gastrointestinal tract & 0.8 & 0.0 & 0.8 \\
\hline Blood & 0.4 & 3.2 & 3.6 \\
\hline Liver & 0.3 & 0.0 & 0.3 \\
\hline
\end{tabular}

diseases has increased by $50.9 \%$; the nervous system diseases, by $40,6 \%$; blood and bloodmaking organs diseases, by $30.2 \%$; the musculoskeletal system diseases, by $13.7 \%$; ear and mastoid diseases, by $13.3 \%$; neoplasms, by $8.3 \%$; injuries and intoxications, by $6.2 \%$; the circulatory system diseases, by $0.9 \%$.

Conclusions. To sum up, we have detected that food products contamination causes high non-carcinogenic risks for the hormonal, cardiovascular, and central nervous systems in children and teenagers and it can lead to health disorders among these population groups.

Uncertainties in assessment of risks related to chemical contamination of food products consumed beyond educational establishments are 1.5-2 times higher than those occurring during assessment of nutrition provided for children and teenagers at their educational establishments due to qualitative laboratory control.

Given all the above-mentioned, we think it is necessary to update regulatory and methodical support for monitoring over quality and safety of food products as a part of social and hygienic monitoring as it will eventually allow to take into account all factors that influence validity of risk assessments.

Funding. The research was not granted any sponsor support.

Conflict of interests. The authors state there is no any conflict of interests.

\section{References}

1. Fetter V.V., Polyakov A.D. Comparative analysis of public health risk determined by chemical contamination of different types of food products. Health Risk Analysis, 2014, no. 2, pp. 55-67. DOI: 10.21668/health.risk/2014.2.07.eng (in Russian).

2. Fomina S.F., Stepanova N.V. Nekantserogennyi risk dlya zdorov'ya detskogo naseleniya g. Kazani, obuslovlennyi kontaminatsiei pishchevykh produktov i syr'ya [Non-carcinogenic risk to health of children population of Kazan, caused by contamination of food products and raw materials]. Aktual'nye voprosy obespecheniya sanitarno-epidemiologicheskogo blagopoluchiya naseleniya na urovne sub"ekta federatsii: Materialy mezhregional'noi nauchno-prakticheskoi internet-konferentsii [Vital issues related to providing sanitary-epidemiologic welfare of the population in a RF region: Materials collected at the regional theoretical and practical conference]. In: A.YU. Popova, N.V. Zaitseva, eds. Perm, 2017, pp. 236-243 (in Russian). 
3. Arnautov O.V. On improvement of the mechanism for establishing and changing indicators of quality and food safety in the regulatory and legal acts of the Eurasian Economical Union. Voprosy pitaniya, 2016, no. 1, pp. 110-116 (in Russian).

4. Bocharov E.P. Otsenka riska zdorov'yu naseleniya na territorii respubliki Tatarstan, svyazannogo s zagryazneniem produktov pitaniya [Assessment of population health risk related to food products contamination in the Republic of Tatarstan]. Voprosy pitaniya, 2015, vol. 84, no.S5, pp. 22 (in Russian).

5. Kon I.Ya., Konovalova L.S., Georgieva O.V. Issues of the support of the quality and safety of baby food. Gigiena i sanitariya, 2013, no. 1, pp. 36-39 (in Russian).

6. Kalinovskaya M.V., Litvinova O.S. Zaichenko, T.A., Sivokhina T.A. Sotsial'no-gigienicheskii monitoring kak instrument obespecheniya bezopasnosti pishchevoi produktsii v Rossiiskoi Federatsii [Social and hygienic monitoring as a tool for providing food products safety in the Russian Federation]. Rossiiskaya gigiena - razvivaya traditsii, ustremlyaemsya v budushchee: Materialy XII Vserossiiskogo $s^{\prime \prime}$ zda gigienistov i sanitarnykh vrachei, 17-18 noyabrya $2017 \mathrm{~g}$. [Russian Hygiene - we develop traditions and head for the future: Materials collected at the XII Russian Conference of hygienists and sanitary inspectors, held on November 17-18, 2017]. Moscow, 2017, pp. 80-82 (in Russian).

7. Onishchenko G.G. The Information on a sanitary-and-epidemiologic condition of general educational establishments and catering services of schoolboys. Voprosy pitaniya, 2008, no. 2, pp. 4-9 (in Russian).

8. Onishchenko G.G. Tasks and strategies of school nutrition in modern conditions. Voprosy pitaniya, 2009, vol. 78, no. 1, pp. 16-22 (in Russian).

9. Potoroko I. Ju., Popova N.V. State policy of Russia in the field of food safety and safety of foodstuff. Modern condition of the question. Vestnik yuzhno-ural'skogo gosudarstvennogo universiteta. Seriya: ekonomika i menedzhment, 2014, no. 21, pp. 92-98 (in Russian).

10. Setko A.G., Vyal'tsina N.E., Mryasova J.K., Plotnikova E.G. Risk zdorov'yu naseleniya, svyazannyi s upotrebleniem kontaminirovannykh pro-duktov pitaniya [Population health risk related to consumption of contaminated food products]. Rossiiskaya gigiena - razvivaya traditsii, ustremlyaemsya $v$ budushchee: Materialy XII Vserossiiskogo s"ez-da gigienistov i sanitarnykh vrachei [Russian Hygiene - we develop traditions and head for the future: Materials collected at the XII Russian Conference of hygienists and sanitary inspectors, held on November 17-18, 2017]. Moscow, 2017, pp. 167-170 (in Russian).

11. Setko I.M., Tymoshenko Evgenija, Setko A.G., Fateeva T.A. Feature microelement balance in the body school food contamination in heavy metal. Zdorov'e naseleniya i sreda obitaniya, 2013, no. 6, pp. 12-13 (in Russian).

12. Novikov S.M., Arutyunyan R.V., Shashina T.V., Sudakova E.V. [et al.]. Opyt otsenki kantserogennogo riska pri vozdeistvii khimicheskikh veshchestv, soderzhashchikhsya $\mathrm{v}$ pishchevykh produktakh [An experience of carcinogenic risk assessment under exposure to chemicals contained in food products]. Rossiiskaya gigiena - razvivaya traditsii, ustremlyaemsya $v$ budushchee: Materialy XII Vserossiiskogo $s^{\prime \prime} e z d a$ gigienistov $i$ sanitarnykh vrachei, 17-18 noyabrya $2017 \mathrm{~g}$. [Russian Hygiene - we develop traditions and head for the future: Materials collected at the XII Russian Conference of hygienists and sanitary inspectors, held on November 17-18, 2017]. Moscow, 2017, pp. 130-133 (in Russian).

13. Sergeev V.V., Klimushkin O.D., Il'ina E.V., Chernykh A.M. Otsenka riska vliyaniya khimicheskikh zagryaznitelei produktov pitaniya [Assessment of risks caused by chemical contaminants in food products]. Rossiiskaya gigiena - razvivaya traditsii, ustremlyaemsya v budushchee: Materialy XII Vserossiiskogo s"ezda gigienistov i sanitarnykh vrachei, 17-18 noyabrya $2017 \mathrm{~g}$. [Russian Hygiene - we develop traditions and head for the future: Materials collected at the XII Russian Conference of hygienists and sanitary inspectors, held on November 17-18, 2017]. Moscow, 2017, pp. 164-167 (in Russian).

14. Pokrovskii A.A. Metabolicheskie aspekty farmakologii i toksikologii pishchi [Metabolic aspects of food pharmacy and toxicology]. Moscow, Meditsina Publ., 1987, 181 p. (in Russian).

15. Ivanova I.L., Kislitsyna L.V. The impact of contaminated food on the incidence of digestive diseases of the population in the Primorsky territory. Zdorov'e. Meditsinskaya ekologiya. Nauka, 2014, vol. 58, no. 4, pp. 85-88 (in Russian). 
16. Kislitsyna L.V., Ivanova I.L., Kiku P.F. Estimation of risk of the likely impact of heavy metals in food on health of population of the Primorsky region. Zdorov'e. Meditsinskaya ekologiya. Nauka, 2015, vol. 62, no. 4, pp. 78-83 (in Russian).

17. Stepanova N.V., Fomina S.F., Valeeva E.R. Gigienicheskaya otsenka bezopasnosti pitaniya naseleniya Respubliki Tatarstan [Hygienic assessment of nutrition safety for population in the Republic of Tatarstan]. Voprosy pitaniya, 2016, vol. 85, no. S2, pp. 36-37 (in Russian).

18. Sorokina A.V., Giguz T.L., Polyakov A.Ya., Bogachanov N.D. Hygienic assessment of actual nutrition of children of school age as a risk factor for the formation of morphological and functional abnormalities. Zdorov'e naseleniya i sreda obitaniya, 2017, vol. 286, no. 1, pp. 27-30 (in Russian).

19. Kon I.Ya., Volkova L.Yu., Dimitrieva S.A. Aktual'nye problemy organizatsii pitaniya shkol'nikov [Vital issues related to organization of nutrition for children]. Zdorov'e naseleniya $i$ sreda obitaniya, 2009, vol. 194, no. 5, pp. 4-8 (in Russian).

20. Kuchma V.R., Rapoport I.K., Gorelova Zh.Yu. Nauchno-organizatsionnye osnovy mo-nitoringa realizatsii eksperimental'nykh proektov po sovershenstvovaniyu organizatsii pitaniya obuchayushchikhsya v GOU sub"ektov Rossiiskoi Federatsii i munitsipal'nykh obshcheobrazovatel'nykh uchrezhdeniyakh [Scientific and organizational grounds for monitoring and implementation of experimental projects aimed at updating organization of nutrition for schoolchildren in the RF regional and municipal educational establishments]. Zdorov'e naseleniya i sreda obitaniya, 2009, no. 5, pp. 9-11 (in Russian).

21. Kuchma V.R., Rapoport I.K., Gorelova Zh.Yu. Monitoring the realization of of experimental projects aimed at improvement of school alimentation in secondary school institutions in the regions of the russian federation and in municipal educational institutions. Zdorov'e naseleniya i sreda obitaniya, 2009, no. 8, pp. 27-29 (in Russian).

Setko A.G., Mryasova J.K., Turin A.V. Risk of health disorders in children casued by consumption of contaminated food products. Health Risk Analysis, 2018, no. 4, pp. 89-95. DOI: 10.21668/health.risk/2018.4.10.eng

Received: 05.03.2018

Accepted: 24.10 .2018

Published: 30.12 .2018 
UDC 616.98: $579.842 .23(470)$

DOI: $10.21668 /$ health.risk/2018.4.11.eng

PRINCIPLES OF CARTOGRAPHIC DIFFERENTIATION AND EPIDEMIOLOGIC ZONING OF NTURAL PLAGUE FOCI APPLIED TO ASSESS AND MINIMIZE POPULATION HEALTH RISKS

\author{
A.A. Kuznetsov ${ }^{1}$, A.N. Matrosov ${ }^{1}$, A.M. Porshakov ${ }^{1}$, A.A. Sludsky ${ }^{1}$, \\ A.A. Kovalevskaya ${ }^{2}$, V.P. Toporkov ${ }^{1}$ \\ ${ }^{1}$ «Microbe» Russian Scientific Research Anti-Plague Institute, 46 Universitetskaya Str., Saratov, 410005, \\ Russian Federation \\ ${ }^{2}$ Astrakhan Plague Control Station, 3 Kubanskaya St., Astrakhan, 414057, Russian Federation
}

In some South American, African, and Asian countries epidemiologic complications in natural plague foci occur due to people consuming meat of rodents, namely rats, bandicoot rats, guinea pigs, etc. People catch bubonic plague when splicing rodents' carcasses.

Our research objects were rules for cartographic differentiation and epidemiologic zoning of natural plague foci that are applied in epidemiologic surveillance performed by plague control authorities in the country.

Our research goal was to unify differentiation rules as it will help to more rationally organize epidemiologic surveillance in natural foci of dangerous infections on a large territory (a region, some regions, the country as a whole).

We suggest to apply a conventional topographic mapping and to take a list of a map scaled 1:25 000 ("a sector") as a minimum formalized unit for spatial analysis. We recommend to perform epidemiologic zoning as per potential epidemiologic hazards that are characteristic for specific sectors. To determine these hazards, we should take into account prevalence and number of potential infection sources in this or that sector. We should also assess a character or a possible course of epizootic processes in populations of infection carriers and (or) carriers of infectious agents, frequency of epizooties detection, density of population who live in this or that area permanently or stay there temporarily, as well as data on morbidity registered there over the last 25 years.

Morbidity, epizootic activity, and precise localization of contagion points are significant arguments for ranking such zones as the most epidemiologically hazardous. A risk of catching plague by people has become higher in natural plague foci on the RF territory due to, for example, an increase in quantity of marmots and gophers that are caught and consumed by local population. In 2014-2016 there were some single cases of people catching bubonic plague in GornoAltaysk highland focus; it substantiated assigning of contagion areas into the most epidemiologically hazardous category. The same situation is observed in plague foci in Tyva Republic and Kalmykia Republic.

Detailed epidemiologic zoning of natural plague foci based on cartographic differentiation is applied to perform well-grounded planning and carrying out examinations and prevention activities in each focus in order to minimize population health risks.

Key words: natural plague foci, cartography, epidemiologic surveillance, hazardous infections, prevention activities.

(C) Kuznetsov A.A., Matrosov A.N., Porshakov A.M., Sludsky A.A., Kovalevskaya A.A., Toporkov V.P., 2018

Aleksandr A. Kuznetsov - Doctor of Biological Sciences, Chief Researcher at the Laboratory for Epizootic Monitoring of the Epidemiologic Department (e-mail: sansanych-50@mail.ru; tel.: +7 (8452)73-46-48; ORCID: https://orcid.org/0000-0002-0677-4846).

Aleksandr N. Matrosov - Doctor of Biological Sciences, Leading Researcher at the Laboratory for Epizootic Monitoring of the Epidemiologic Department (e-mail: anmatrosov@mail.ru; tel.: +7 (8452)73-46-48; ORCID: https://orcid.org/0000-0003-4893-7188).

Aleksandr M. Porshakov - Candidate of Biological Sciences, Chief Researcher at the Laboratory for Epizootic Monitoring of the Epidemiologic Department (e-mail: rusrapi@microbe.ru; tel.: +7 (8452)73-46-48; ORCID: https://orcid.org/0000-0003-3363-765X).

Aleksandr A. Sludskii - Doctor of Biological Sciences, Leading Researcher at the Laboratory for Epizootic Monitoring of the Epidemiologic Department (e-mail: rusrapi@microbe.ru; tel.: +7 (8452)73-46-48; ORCID: https://orcid.org/0000-0003-4705-61-51).

Anastasiya A. Kovalevskaya - Epidemiologist at the Epidemiologic Department (e-mail: antichum@astranet.ru; tel.: +7 (8512)33-37-00).

Vladimir P. Toporkov - Doctor of Medical Sciences, Chief Researcher at the Laboratory for Epidemiologic Analysis and Prediction (e-mail: rusrapi@microbe.ru; tel.: +7 (8452)73-46-48). 
In some South American, African, and Asian countries epidemiologic complications in natural plague foci occur due to people consuming meat of rodents, namely rats, bandicoot rats, guinea pigs, etc. People catch bubonic plague when they splice rodents' carcasses [1-3]. In Russia and neighboring countries most plague cases occurred due to a transmissible mechanism when an infectious agent was caught via a bite of an infected flea [4]. Nowadays commercial spices of marmots have recovered their numbers and populations of little and long-tailed gophers have also grown; local population are now hunting these animals more actively as their meat is consumed as a delicacy, cavitory fats are used as a medication, and their skins are curried. In 2013-2016 people, including children, caught bubonic plague in marmot foci in Kyrgyzstan and Russia; contagion occurred due to contact between damaged skin and carcasses of plague-carrying animals when they were spliced [5-8]. In this relation, it is becoming more vital to get better insight into contemporary situation with this infection and other ones that are being registered again [9]. Epidemiologic surveillance in plague foci is now performed with new techniques, including geoinformation systems (GIS) and technologies that allow to systematize great volumes of retrospective and live data on the dynamics of spatial and biocenotic structure of foci [10-12].

Epidemiologic surveillance over plague helps to achieve a primary goal, namely epidemiologic well-being of population. Epizootologic monitoring in natural foci of this extremely dangerous infection is one of its basic instruments; in Russia this monitoring is performed by anti-plague establishments on the basis of their differentiation as per a formal-territorial principle [13, 14]. Minimal structural differentiation units are standardized and systematized via conventional mapping of state topographic maps that is common for the whole country territory. A list of a topographic map scaled 1:25,000 which is called "sector" is taken as a minimal unit. The necessity to apply such formalized units can be explained by the following: plague foci can be located in different administrative and economic units (regions, districts, etc.) that are large in their square, variable in their configuration, and are built as per economic, national, and other social and political criteria without taking natural zoning into account. For example, the whole GornoAltaysk highland natural plague focus is located within just one administrative district, Kosh-Agachskiy. Such administrative differentiation (or identification) of foci territories is undoubtedly necessary, but it is not sufficient for more profound and targeted assessment of epidemiologic state existing on a specific area. But if vast administrative territories are divided into relatively small standard parts, it leads to a drastic increase in possibilities for detecting and mapping of dangerous zones and it becomes especially vital when such zones don't have any apparent natural boundaries. The same absence of detailing is also characteristic for biogeographical zoning based on maps of natural zones, landscape or geobotanical provinces. Additional argument for introducing such small formalized differentiation units is a necessity to arrange data that are accumulated during epizootologic research; such arrangement is especially vital when geographic information technologies are applied $[13,14]$.

Research techniques. We predominantly applied cartographic techniques in our work. Anti-plague establishments, just as any other anti-epidemic ones, apply two categories of maps in their functioning. A basic type is a general vector interactive map that comprises large territories and is used for mapping, generalization and demonstration of departmental data, their assessment and comprehensive analysis. Maps scaled 1:1,000,000 are accessible for free and they can be used as a basis for creation of subject skeleton maps with medical contents that are then applied in reports and reviews. But it is necessary to 
have topographic maps scaled $1: 100,000$ or 1:200,000 for overall planning and organization of inspections and prevention activities. Epizootologic monitoring that is performed directly in a natural focus as well as scientific research requires multi-list topographic maps scaled 1:25,000 (both vector and raster ones) that can be downloaded into mobile devices or a notebook.

Nowadays, a wide range of users have free access to open digital topographic maps with various scales, up to $1: 25,000$. There are electronic maps, both vector ones and their standardized raster copies (tiles) that can be printed on a large-format printer and it allows more convenient work with them in field conditions.

We should also pay some attention to a system of coding that is applied to formalterritorial units, or sectors, and was developed for registration of natural plague foci on the RF territory $[13,14,15,16]$. According to it, each sector is assigned a digital code (cipher) which is formed from nomenclature of a relevant list of a topographic map scaled 1:25,000 and two-digit number of a natural plague focus. As each sector has its unique code, it provides additional opportunities for spatial identification of epidemiologic materials. Besides, as it was revealed by shaping of natural plague foci, in many cases sharp geodetic contours of sectors (lists of topographic maps) provide the only opportunity to determine an outer boundary of a focus if there are no linear elements in a landscape that can serve as such boundary in this particular area. But here we require reliable data on occurrence or absence of any enzootic signs as regards this particular infection on various sides from this formal boundary.

At present there is a most significant requirement to provide obligatory geo-coding of any information obtained via monitoring with global positioning systems GLONASS/GPS; that is, it is obligatory to state a longitude and latitude of any point where field data were collected, infection carriers numbers and numbers of infectious agent carriers were accounted, or any other work was performed on natural foci territory. When exact geographic coordinates are stated, it makes research data suitable for application in geographic information systems and provides an opportunity for their fast visualization and spatial analysis [14]. Besides, coordinates of any point at which data were collected automatically show which sector this point is located in as lists of topographic maps are framed with specific parallels and meridians.

Differentiation rules for enzootic territories are clearly regulated and it provides a significant advantage as this differentiation is greatly suitable for application for natural foci registration based on GIS principles. Rules for geographic differentiation of natural plague foci that are described in this paper can be applied by sanitary-epidemiologic institutions for mapping, systematization, and registration of natural foci of other dangerous and extremely dangerous infections. This proposition was our basic research goal.

Natural plague foci on the RF territory and in neighboring countries have a twodigit number (from 01 to 46) which comes from foci numbering accepted in the USSR; it is given in the right part of a cipher in round brackets $[14,15,16]$. To register natural foci of other infections, we can require greater number of digits that provides identification of foci as per an infection and their specific denomination that can have regional, landscape, or any other origin.

A cartographic model of the whole RF territory can be found on state topographic maps made in Gauss-Krueger cross-cylindrical projection; these maps have standard mapping based on an international millionscaled map. The biggest scale of maps that are in open access is equal to 1:25,000. Dimensions and locations (coordinates) of sectors are strictly regulated by normative and regulatory documents issued by the country cartographic and geodetic service and are not subject to any changes by other authorities. 
It provides unification and standardization of differentiation units that are applied in antiepidemic activities and prevents from any mistakes in determining exact points where field data were collected during epizootologic examinations. In order to synchronize differentiation units with cartographic analogues and to make documentation keeping more convenient, the order in which sectors are given their codes is to coincide with the rules fixed by the state cartographic, topographic and geodetic service for drawing up nomenclatures of topographic maps with variable scales. These rules are described in detail in manuals and reference literature on geodesy, topography, and cartography and cover both letter designations of lists and their digital analogues (nomenclature codes ${ }^{1}$ ).

According to these rules, Latin letters that denominate latitudinal rows on "millionscaled" maps ("10-km-scale") are replaced with ordinal numbers of rows starting from the equatorial (first) row A and step-by-step moving to the North Pole. Rows K, L, and M, where natural plague foci are located in the $\mathrm{RF}$, are numbered 11,12 , and 13. A list of a million-scaled map is divided into 144 lists with 100-thousand ("kilometer") scale (from 001 to 144); each such list contains 16 lists of 25-thousand ("250-meters") scale.

An overview of numeration given to lists of maps with above-mentioned scales (and, accordingly, sectors) is given on Figure 1 that shows one of sectors in Prikaspiyskiy sand plague focus. This sector has the following code: 123807224(43) where an underlined part corresponds to nomenclature of a list belonging to the International topographic map scaled 1:1,000,000. The sector corresponds to a list of a 25-thousand scaled map with its number L-38-72-Б- $\Gamma$ in the focus No. 43 (letters a, $\sigma, \mathrm{B}, \Gamma$ are replaced with numbers 1,2 , 3, 4 regardless of their register). Lists of the next map with larger scale are numbered from left to right and top-down starting from the upper left (north-western) corner. Nomenclature of a list that was printed in a print office is given beyond the frame, either on the top to the right or in the middle (variant with numbers is given in blue color - 12-38-072-2-4, variant with letters is black - L-38-72-Б-г). When there are fragments of different foci located in the same sector and there are distinct landscape boundaries between them,

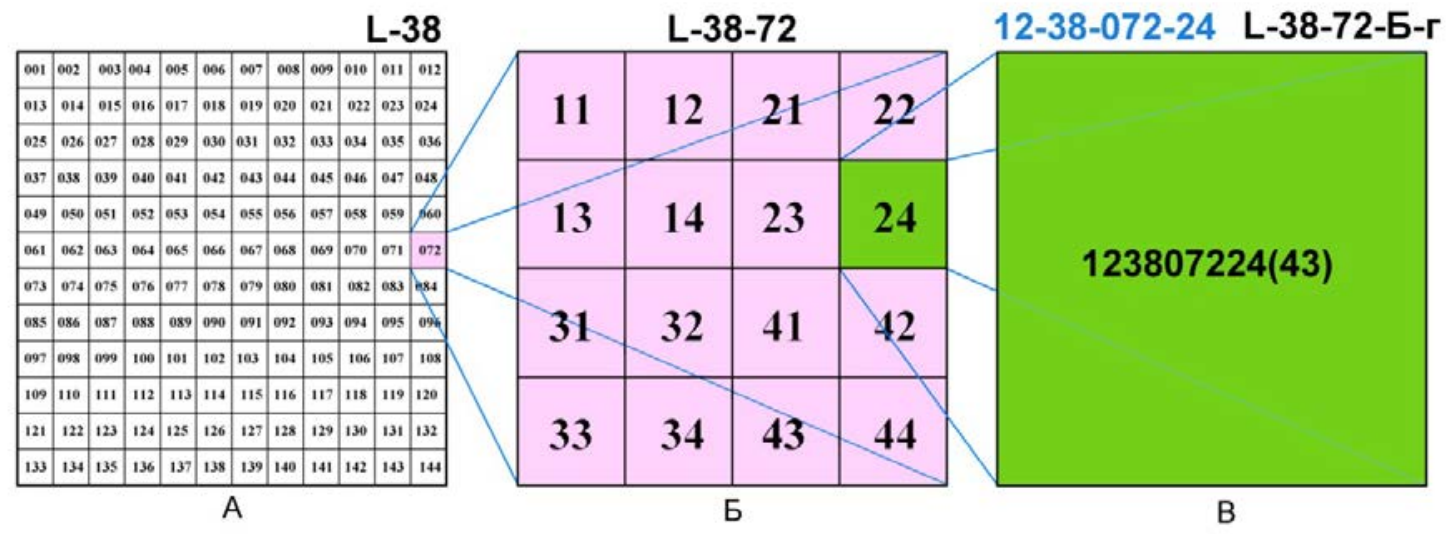

Figure 1. Order of numeration and placement: A shows lists of maps scaled 1:100,000 within one list of a map scaled 1:1,000,000; Б shows lists of maps scaled 1:25,000 (sectors) within one list of a map scaled 1:100,000; B is nomenclature of a list belonging to a map scaled 1:25,000 and a code of a relevant sector

${ }^{1}$ The Guide on cartographic work and printing of maps. Part 1. Drawing up and preparing topographic maps scaled 1:25,000, 1:50,000, 1:100,000 for printing. GKINP-05-050-77. - M., 1978. - 78 p. 
each such fragment (relevant area on a map of a sector) is given its code that contains the original number of a focus in brackets. According to this rule, a code of a sector with a focus number on the border of an enzootic territory is given only to its focus part (area), if a boundary of a focus is drawn as per a landscape element (for example, a bank of a river or a sea) and not as per a frame of this sector.

Lists of topographic maps (just as sectors corresponding to them) are limited by frames that are represented by specific parallels and meridians. Consequently, geographic coordinates of any point on the Earth surface automatically show which list (sector) this point is located in (in our case it is somewhere within the eastern part of the northern hemisphere). In case any code of any sector is lost, it can be easily recovered as per coordinates of a point where filed materials were collected bearing in mind that meridians limiting a sector "width" are located 7' 30" away from each other starting from the Greenwich ("zero") meridian, and parallels limiting a sector "height" are located 5' 00" away from each other starting from the Equator.

Therefore, data on location of points where epizootologic research took place on this or that territory allow to group the obtained results as per significantly small standard formal-territorial units, or sectors (with their approximate square being $10 \times 10 \mathrm{~km}$ ). This additional grouping still allows any materials to be combined as per administrative districts and any other units that an examined territory is divided into. Differentiation as per sectors also allows to analyze spatial organization of natural infection foci in greater details since administrative districts are substantially greater in their sizes than sectors, and their configurations and sizes vary significantly thus making districts-based analysis extremely rough. Visualization of sector frames on a vector map that is shown on a PC screen is provided by a grade grid with relevant fractionality.
Cartographic technique based on up-todate developments in geoinformatics is widely applied worldwide to study spread of diseases [17, 18]. Epidemiologic zoning of enzootic territories as per potential epidemic danger of this or that area is of great practical interest. When a territory is divided into standard formalized parts (sectors), it is convenient for zoning and provides better visualization of it. By now, Rospotrebnadzor offices have accumulated great volumes of information on epizootic and epidemic signs of various natural foci infections that allow to differentiate vast enzootic territories as per an epidemiologic criterion $[19,20]$. It is important to make a correct choice on parameters that are applied to assess how dangerous this or that area is in terms of possible contagion of population. The basic parameters here are occurrence, distribution peculiarities, and quantity (number and density) of contagion sources. Contagion sources can be represented by warm-blooded carriers and (or) arthropods carriers (if there are any as per this or that infection enzooticity). Any registration of an infectious agent within animals population on this or that territory is also important regardless of how frequently this agent is registered. Any detected cases of contagion among population with their exact geographic localization also matter a lot. However, even if there are no disease cases on this or that territory, it is important to take into account density of population that can contact contagion sources if there are any and it is especially vital if any epizootic process was registered there in past or is registered now.

Contemporary improved epidemiologic zoning is based on epizootologic and epidemiologic status as well as on population density on a territory of specific sectors. Retrospective characteristics of epizootic signs within each sector has 2 positions: plague epizooties were detected at least once (over the last 50 years) or they have never been detected at all. The third position is epidemi- 
ological and it is related to cases of contagion among population over the last 25 years. Density of population living within a sector is also described as per 2 positions: less than 1 person per $1 \mathrm{~km}^{2}$ and more than 1 . Both characteristics are combined in a table where this or that combination of positions determines a level of potential epidemic danger in conventional scores with the following characteristics assigned to them: 1 means low level; 2, average; 3 , high; 4, extremely high (Table).

Table

A level of potential epidemic danger (in scores) on a territory of a sector depending on plague occurrence and population density

\begin{tabular}{|l|c|c|}
\hline \multirow{2}{*}{$\begin{array}{c}\text { Plague occurrence } \\
\text { in a sector }\end{array}$} & \multicolumn{2}{|c|}{$\begin{array}{c}\text { Population density } \\
\text { (people per } 1 \mathrm{~km}^{2} \text { ) }\end{array}$} \\
\cline { 2 - 3 } & Less than 1 & More than 1 \\
\hline No occurrence & 1 & 2 \\
\hline $\begin{array}{l}\text { There have been } \\
\text { plague epizooties } \\
\text { (over the last } 50 \\
\text { years or more) }\end{array}$ & 2 & 3 \\
\hline $\begin{array}{l}\text { People have caught } \\
\text { plague (over the last } \\
\text { 25 years) }\end{array}$ & 4 & 4 \\
\hline
\end{tabular}

Events that have happened over last years in Gorno-Altayskiy highland natural plague focus [21] determine the necessity to apply high-level gradation that is established only for three sectors in Altay mountains. However, profound specific and non-specific prevention activities that have been performed in the focus provide some sort of assurance that a number of such sectors will not grow in future. Nevertheless, population morbidity is registered annually or almost annually in natural foci of other dangerous infections; therefore, application of the fourth gradation there will be quite justified. On the whole, experience in epidemiologic zoning of natural plague foci can be applied for zoning of other infections foci that incorporates two or three gradations of potential epidemic danger.
In order to make epizootologic monitoring rational and efficient, it is necessary to accomplish epizootologic differentiation of an enzootic territory that is also made within specific sectors. Occurrence, intensity and duration of epizootic processes within populations of infection carriers and infection agent carriers are basic criteria applied to assess epizootologic status of a sector territory. Frequency of registered epizooties assessed over a long period of time is a simple but quite objective parameter; this frequency can be given within a specific sector or it can be based on increased detailing. Information on potential sources of contagion or infected animals is applied via extrapolation and interpolation of data obtained from a limited number of places and with variable techniques. Accounting and inspection work that is performed periodically in regulated volumes is a basic source of information. Extrapolation is basically performed as per landscape criteria when large-scaled topographic maps and images taken from space are applied; or it is done with round technique [13]. Interpolation involves averaging of data taken from neighboring cells in case there are no data on this or that sector.

Figure 2 gives an example of epidemiologic zoning on skeleton maps of Prikaspiyskiy sand plague focus (A) and Gorno-Altaiskiy highland plague focus (B) that have attracted a lot of attention due to significant epizootologic and epidemiologic signs [21]. A result of foci zoning was obtained via analyzing history of epizootic signs during the whole examination period, present distribution of population across the territory and single cases of the diseases among population in the Altay republic in 2014-2016 [21].

These single cases of bubonic plague among population gave grounds for ranking contagion areas (three sectors) among territories with the highest epidemic danger. It is important to mention that local population poached gray marmots and consumed meat of these animals that were the basic carriers 

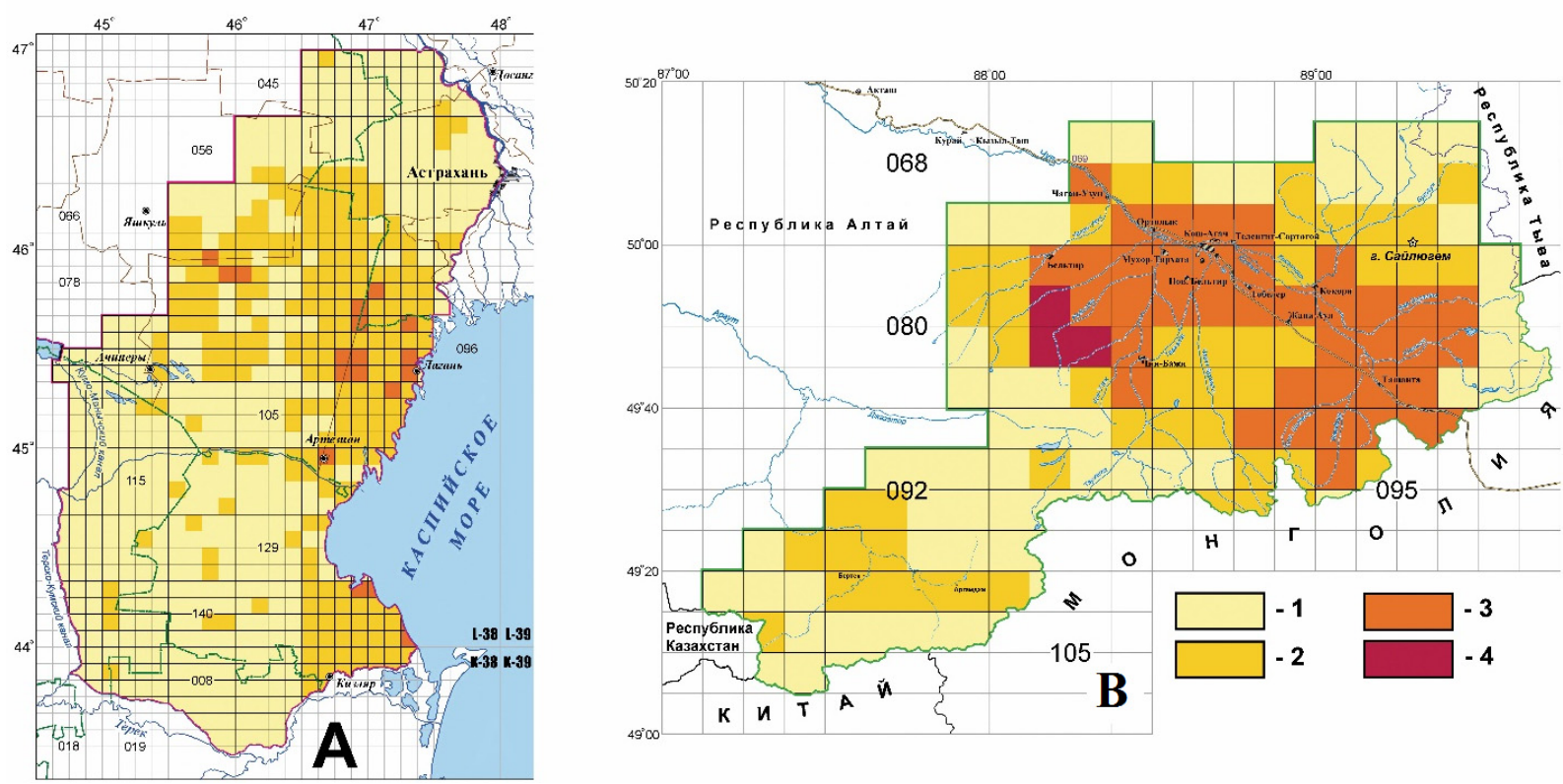

Figure 2. Differentiation of sectors located in Prikaspiyskiy sand plague focus (A) and Gorno-Altaiskiy highland plague focus (B) as per a level of potential epidemic danger: 1 means low level; 2, average; 3 , high; 4 , extremely high

of the plague agent. People spliced animals' carcasses at home and it resulted in contagion.

Results and discussion. It is necessary to highlight that speed, validity, and correctness of epizootologic assessment directly depend on how well an anti-plague service is equipped with contemporary means and devices for information gathering and analysis. When field groups are equipped with specialized vehicles, such as diagnostic autolaboratories and mobile housing, it increases their mobility and makes field research more comfortable and qualitative. Computers equipped with Internet connection, satellite navigators, large-scaled topographic maps, and high-resolution images taken from space help to bind areas with persistent occurrence of infectious diseases to landscape structures of various types or anthropogenic elements. Video-inspection and photo-fixation of a territory performed with air drones or even from helicopters is another promising observation technique.
Conclusion. Therefore, cartographic systematization and differentiation of natural infections foci of various etiology on the whole country territory can substantially enrich our knowledge on their location, sizes, and epidemiologic danger. Targeted work with maps secures correct spatial perception of vast enzootic territories and allows to objectively assess actual spread of contagion sources that are dangerous for population. Unification of differentiation principles for natural plague foci that is being implemented at present makes it possible to recommend these principles as a standard for zoning of natural foci of other dangerous infectious diseases; zoning itself is necessary for substantiated planning and accomplishing observation and prevention activities in each focus.

Funding. The research was not granted any sponsor support.

Conflict of interests. the authors state there is no any conflict of interests. 


\section{References}

1. Lapshov V.A., Bokshtein F.M., Inapogi A.P. Melkie mlekopitayushchie selenii Gvinei [Small mammals of Guinean villages]. Byulleten' Moskovskogo obshchestva ispytatelei prirody. Otdel biologicheskii, 1992, no. 1, pp. 33-43 (in Russian).

2. Malekani V., Paulus J. Quelques aspects d la cjnsommation du cricetome, Cricetomys (Rongeur) par des populations zairoises. Tropiculture, 1989, vol. 7, no. 4, pp. 141-144.

3. Whitaker R., Murafi M. Rodent control by Irura tribals. Bombay Natur. Hist. Soc., 1988, vol. 85 , no. 2 , pp. $263-270$.

4. Kokushkin A.M., Naumov A.V., A Kologorov.I., Marysaev V.B. Epidemicheskaya aktivnost' prirodnykh ochagov chumy v Rossii i drugikh stranakh sodruzhestva nezavisimykh gosudarstv za 120 let [Epidemic activity of natural plague foci in Russia and other countries of the Commonwealth of Independent States for 120 years]. Problemy osobo opasnykh infektsii, 1994, vol. 47, no. 4, pp. 3-28 (in Russian).

5. Balakhonov S.V., Korzun V.M., Kosilko S.A., Mikhailov E.P., Shchuchinov L.V., Mishchenko A.I., Zarubin I.V., Rozhdestvenskii E.N., Denisov A.V. Actual Aspects of Epidemiological Well-Being Support Anti-PLAgue for Population in Altai Republic. Epidemiologiya $i$ vaktsinoprofilaktika, 2016, vol. 89, no. 4, pp. 42-48 (in Russian).

6. Barnes S., Peck A. Mapping the future of health care: GIS applications in Health care analysis. Geographic Information systems, 1994, no. 4, pp. 31-33.

7. Blackburn J.K., McNyset K.M., Curtis A., Hugh-Jones M.E. Modeling the Geographic Distribution of Bacillus anthracis, the Causative Agent of Anthrax Disease, for the Contiguous United States using Predictive Ecologic Niche Modeling. Am. J. Trop. Med. Hyg., 2007, vol. 77, no. 6, pp. 1103-1110.

8. Clarke K.C., Osleeb J.R., Sherry J.M., Meert J.P., Larsson R.W. The use of remote sensing and geographic information systems in UNICEF's dracunculiasis (Guinea worm) eradication effort. Prew Vet. Med., 1991, no. 11, pp. 229-235.

9. Cliff A.D., Haggett P., Smallman-Raynor M. World Atlas of Epidemic Diseases. London, 2004, $212 \mathrm{p}$.

10. Dangendorf F., Herbst S., Reintjes R., Kistemann T. Spatial patterns of diarrhoeal illnesses with regard to water supply structures - a GIS analysis. International Journal of Hygiene and Environmental Health, 2002, vol. 205, no. 3, pp. 183-191.

11. Glass G.E., Schwartz B.S., Morgan J.M., Johnson D.T., Noy P.V., Israel E. Environmental Risk-Factors for Lyme-Disease Identified with Geographic Information-Systems. American Journal of Public Health, 1995, no. 85, pp. 944-948.

12. Tempalski B.J. The case of Guinea worm: GIS as a tool for the analysis of disease control policy. Geographic Information Systems, 1994, no. 4, pp. 8-32.

13. Kuznetsov A.A., Kutyrev V.V., Matrosov A.N., Toporkov V.P. Improvement of Monitoring of Natural Plague Foci Based on the Analysis of Ecologic and Epizootiologic Regularities of their Functioning. Problemy osobo opasnykh infektsii. 2004, vol. 88, no. 2, pp. 12-16 (in Russian).

14. Kuznetsov A.A., Porshakov A.M., Matrosov A.N., Kuklev E.V., Korotkov V.B., Mezentsev V.M., Popov N.V., Toporkov V.P., Toporkov A.V., Kutyrev V.V. Prospects of GIS-Passportization of Natural Plague Foci in the Territory of the Russian Federation. Problemy osobo opasnykh infektsii, 2012, vol. 111, no. 1, 48-53 (in Russian).

15. Prirodnye ochagi chumy Kavkaza, Prikaspiya, Srednei Azii i Sibiri [Natural foci of the plague of the Caucasus, Caspian, Central Asia and Siberia]. In: G.G. Onishchenko, V.V. Kutyrev eds. Moscow, Meditsina Publ., 2004, 192 p. (in Russian).

16. Soldatkin I.S., Rudenchik Yu.V., Popov N.V., Kuklev E.V., Kuznetsov A.A., Matrosov A.N. Pasportizaciya prirodnyh ochagov chumy na territorii stran SNG (kartograficheskie materialy) [Certification of natural plague foci in the territory of the CIS countries (cartographic materials)]. Saratov, 2000, 65 p. (in Russian).

17. Malkhazova S.M. Mediko-geograficheskii analiz territorii: kartografirovanie, otsenka, prognoz [Medical geographical analysis of territories: mapping, assessment, forecast]. Moscow, 2001, 240 p. (in Russian). 
18. Koch T. Cartographies of Diseases. Maps, Mapping, and Medicine. Redlands, 2005, 388 p.

19. Kuklev E.V., Soldatkin I.S., Khot'ko N.I. Epidemicheskii potentsial prirodnykh ochagov chumy i ego otsenka. Epidemiologiya i profilaktika prirodno-ochagovykh infektsii [Epidemic potential of natural plague foci and its assessment. Epidemiology and prevention of natural focal infections]. Saratov, 1981, pp. 3-8 (in Russian).

20. Cadastre of epidemic and epizootic manifestations of the plague in the territory of the Russian Federation and neighboring countries (from 1876 to 2016) [Cadastre of epidemic and epizootic manifestations of plague in the territory of the Russian Federation and neighboring countries (from 1876 to 2016)]. In: V.V. Kutyreva, A.Yu. Popova. Saratov, Amirit LLC Publ., 2016, 248 p. (in Russian).

21. Korzun V.M., Balakhonov S.V., Kosilko S.A. Mikhailov E.P., Mishchenko A.I., Denisov A.V., Rozhdestvensky E.N., Chipanin E.V. Bazarova G.H., Yarygina M.B., Abibulaev D.E., Shefer V.V. Gorno-Altai Natural Plague Focus Epizootical and Epidemical Activity in 2012-2016. Epidemiologiya $i$ vaktsinoprofilaktika, 2017, vol. 92, no. 1, pp. 36-38. DOI: 10.31631/2073-30462017-16-1-36-38 (in Russian).

Kuznetsov A.A., Matrosov A.N., Porshakov A.M., Sludsky A.A., Kovalevskaya A.A., Toporkov V.P. Principles of cartographic differentiation and epidemiologic zoning of ntural plague foci applied to assess and minimize population health risks. Health Risk Analysis, 2018, no. 4, pp. 96-104. DOI: 10.21668/health.risk/2018.4.11.eng

Received: 10.11 .2018

Accepted: 14.12.2018

Published: 30.12.2018 


\title{
RISK MANAGEMENT. RISK COMMUNICATION
}

UDC $316.77+613.2$

DOI: $10.21668 /$ health.risk/2018.4.12.eng

\section{STRATEGY AND TACTICS FOR BUILDING UP EFFICIENT RISK-COMMUNICATIONS IN THE SPHERE OF FOOD PRODUCTS SAFETY}

\author{
I.V. May ${ }^{1}$, N.A Lebedeva-Nesevrya ${ }^{2}$, A.O. Barg $^{2}$ \\ ${ }^{1}$ Federal Scientific Center for Medical and Preventive Health Risk Management Technologies, \\ 82 Monastyrskaya Str., Perm, 614045, Russian Federation \\ ${ }^{2}$ Perm State University, 15 Bukireva Str., Perm, 614990, Russian Federation
}

\begin{abstract}
The authors highlight that contemporary social and economic processes require development of a new paradigm for discussing human health risks caused by food products distribution (risk-communications). Today such a model is replaced with a "prototype" of risk-communication, or simple informing. And as there is no "feedback" from risk recipients, it is impossible to adequately adjust information flows or assess their efficiency. Consequently, risks tend to be underestimated or aggravated by consumers. Working our decisions on managing risks and plans how to implement them are to be solved jointly by experts, authorities, and population.

It is shown that there are some basic ways to build up an efficient risk-communications system in the sphere of food products safety; to do that, we need to achieve greater information activity and interest of population in issues related to products quality and safety; to form a stable attitude towards self-preserving behavior among people; to improve a state system for interaction between all the concerned parties on issues related to population health and food products safety. It is extremely important to fully use channels for information dissemination that are in demand by a target audience (for example, active application of social media) and to created conditions for public discussions about risks. Tactical tasks are methodical guidance on forms and means of providing information about health risks as they are to be relevant for a target audience. Expert community involvement into a constructive risk dialogue is a significant tool for increasing riskcommunications efficiency. As population tends to trust scientists, experts, and doctors more than public persons, representatives from these expert groups are to play a significant social role in a system of efficient risk-communications.

Key words: food products, safety, risk-communications, consumer decisions, risk management, information activity.
\end{abstract}

Provision of population with safe food products is a strategic task for our state and it is fixed in the RF Food Security Doctrine ${ }^{1}$. Special attention is paid to threats to food security that are related to a drastic growth in food products variety, wider ranges of applied technologies and raw materials, trade barriers removal, liberalization of state control and surveillance functions, and intense influence exerted on consumers by mass me- dia. Uncertainty in food products sphere is growing fast and the process is determined, among other things, by application of nanotechnologies [1] and genetically modified organisms [2] in food industry. Given that, the UN Food and Agricultural Organization (FAO) states that development of efficient risk communications is an effective way to decrease risks related to food products safety [3].

(c) May I.V., Lebedeva-Nesevrya N.A, Barg A.O., 2018

Irina V. May - Doctor of Biological Sciences, Professor, Deputy Director for Scientific Work (e-mail: may@fcrisk.ru; tel.: +7 (342) 237-25-47; ORCID: https://orcid.org/0000-0003-0976-7016).

Natalya A. Lebedeva-Nesevrya - Doctor of Sociological Sciences, Associate Professor, Professor at Sociology Department (e-mail: natnes@list.ru; tel.: +7 (342) 239-63-29; ORCID: https://orcid.org/0000-0003-3036-3542).

Anastasiya O. Barg - Candidate of Sociological Sciences, Associate Professor at the Department of Sociology (e-mail: an-bg@yandex.ru; tel.: +7 (342) 239-63-29; ORCID: https://orcid.org/0000-0003-2901-3932).

${ }^{1}$ On Approval of the RF Food Security Doctrine: The RF President Order issued on January 10, 2010 No. 120 [Websource] // Garant. - URL: http://base.garant.ru/12172719/ (date of visit September 22, 2018). 
Experts from the US National Institute for General Medical Sciences determine risk communications as "a process of information exchange on a risk (its nature, level, factors, and ways to manage it) between all the concerned parties or "stakeholders" that can be individuals, groups, or social institutions" [4]. The same concept is accepted by Russian researchers as well [5-7]. Efficient and fullfledged risk communication is always a dialogue when risk manufacturers and risk consumers as well as mediators such as authorities, mass media, or public organizations openly express their own opinions on a risk in order to resolve an existing social conflict. Consequently, consumers are involved into risk-related decision making. Overall, we can spot out three levels in information exchange that goes on during a risk communication process in the food products sphere. The first one is "information" when manufacturers, authorities, or any other institutions or organizations spread information about a risk for consumers' health without taking into account any possible feedback; a "dialogue" when information about a risk spreads via two-direction communication channels and is discussed; "engagement" when all the concerned parties can influence risk-related decisions [3].

Risk communications in the food products sphere can concentrate on the following topics or risks caused by a) chemical, microbiological, and physical contamination of food products [8], b) technological processes applied in food manufacturing [9], c) consequences of a food crisis [10], d) everyday practices related to food products handling [11]. Besides, new scientific data on risks related to food products safety can also be a specific topic for a discussion [12].

Frever et al. (2007) state that a key target of risk communication is to provide population with information that helps them to make "a well justified consumer decision" [10]. Ac- cording to data presented by J.L. Lusk and B. Briggeman, food products "safety" together with them "being natural", their price, taste and nutritional properties are significant criteria that influence food-related decision making [13]. And as per data provided by Martinez-Ruiz M.P. (2006) certain consumer groups (families with children, people with high incomes) rank food safety among the key criteria for decision making, and trends related to Americans' consumer behavior indicate that health-related attributes of consumer products, for example, use for health, absence of harm to health, conformity with healthy nutrition principles are becoming even more significant than price or a convenience related to buying itself [14].

As per data that can be found in domestic research, food products safety is also important for Russians. Thus, according to a questioning performed by the Russian Public Opinion Research Center in November 2018, $83 \%$ respondents read information on a product shelf life on a label when they choose food products, $51 \%$ are interested in a product structure and an its ingredients, $37 \%$ want to know who manufactured a product ${ }^{2}$.

Risk communication in the sphere of food products safety can also be performed in order to influence consumers' behavioral attitudes to minimize their risky behavior since having information that a product is unsafe doesn't guarantee this product is not consumed [15]. Results of sociological questionings performed in the RF confirm these statements. Thus, for example, as per data obtained by the "Public Opinion" Fund in 2014, Russians were well aware that fast food and street food was unsafe as people were asked "Are fast food outlets more useful or more harmful? Or they are approximately fifty-fifty?" and more than $40 \%$ respondents chose "more harmful" answer" Respondents mentioned the following harmful things about fast food outlets: "this food is

\footnotetext{
${ }^{2}$ Consumer behavior: a choice made by Russians [Web-source] // RPORC official web-site. - URL: https:// wciom.ru/index.php?id=236\&uid=9413 (date of visit September 22, 2018).

${ }^{3}$ Russians about fast food. What use and what harm Russians see about fast food restaurants [Web-source] // POF official web-site. -URL: https://fom.ru/ekonomika/11723 (date of visit September 22, 2018).
} 
dangerous as it causes stomach diseases" (34\% respondents), "low quality products" (18\%), "products structure is unknown, a lot of chemical additives" (12\%). But still, 45\% men and $36 \%$ women visit such places from time to time $(40 \%$ respondents in the overall sampling, 53\% and 49\% respectively in Moscow and cities with a population greater than a million). $59 \%$ respondents aged from 18 to 30 periodically buy fast food.

A decrease in social tension can be an ultimate goal of risk communication (for example, when results of experts judgment on a risk state it is quite permissible but consumers are still rather concerned) [16]. A necessity to discuss risks openly is in this case determined by a discrepancy between "images of a risk" that exist in experts' minds and ordinary people's ones; there can also be a discrepancy in how a risk is perceived by consumers, manufacturers, scientific community, and public authorities. Thus, Macgregor (1994) and Wu (2013) give evidence that public perception of food-related risks is to a great extent linked with impacts exerted by "psychometric factors" [17], or a degree to which a risk is "known" and "understood" by broad masses of population, how well it can be controlled, whether there are any benefits that can be derived from its realization, a number of people prone to it, etc., perceptible attributes of a products, and effects produced by mass media [18]. Food-related risks are perceived by people as something opposite to "quality" and "controllability", and here "quality" is associated with food being "fresh" and "manufactured locally", and "controllability" means that there are formal signs proving it has been "checked" by official institutions (tags, labels, any notifications a product conforms to quality standards) [20]. Consequently, various social (social-demographic, social-occupational, and territorial) groups give different charac- teristics of a risk, and situations perceived as safe ones can actually be rather risky [21]. A perception of genetically modified food products by population and experts is a very good example. Information placed on the WHO official web-site in "Food Safety" section explains that genetically modified products "currently available on the international market have passed safety assessments and are not likely to present risks for human health" ${ }^{4}$. But still, according to the results of a representative questioning performed by RPORC among Russians in 2014, 82\% respondents thought (they chose "rather agree" answer) that "GM foods are harmful for health", $67 \%$ respondents believed such foods caused cancer, $60 \%$ thought they could lead to infertility, and $59 \%$, to mutations ${ }^{5}$. As a result, most Russians were in favor of a complete ban on GM foods on the RF territory (Figure 1).

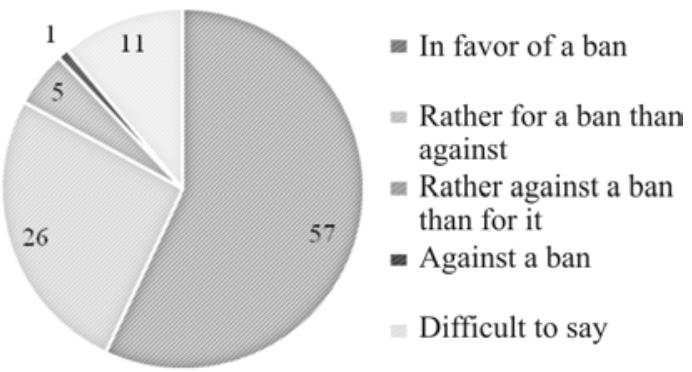

Figure 1. Russians' opinion on prohibition of GM foods on the RF territory (RPORC questioning results, 2014, in \% of the overall number of respondents)

Public opinion on the matter has actually remained static over several years; thus, in 2007 72\% Russians were sure that genetically modified additives in food products could exert adverse influence on people's health ${ }^{6}$. Data obtained via a questioning performed in China in 2016 reveal that $41 \%$ respondents had negative attitudes to GM foods, and only $11 \%$ of the overall number of respondents in that sam-

\footnotetext{
${ }^{4}$ Food Safety [web-source] // the WHO official web-site. - URL: http://www.who.int/foodsafety/areas_work/foodtechnology/faq-genetically-modified-food/ru/(date of visit September 22, 2018).

${ }^{5} \mathrm{GM}$ foods: pro and contra [Web-source] // RPORC official web-site. - URL: https://wciom.ru/index.php?id=236\&uid=691 (date of visit September 18, 2018).

${ }^{6}$ Genetically modified food additives: awareness and opinion. November 29, 2007. [Web-source]// POF official web-site. URL: http://bd.fom.ru/report/cat/business/ec_goods/d074823 (date of visit September 18, 2018).
} 
pling stated they understood basic principles of genetic engineering [22]; that is, reasons for people's disbelief in GM foods safety could be based, among other things, on very poor awareness of population on the matter.

An opposite case is when a risk is overestimated by experts in comparison with population and it is also quite possible. For example, as per results of a questioning performed among 90 British medical experts, most of them overestimated risks of lethal reactions caused by anaphylaxis among children with food allergies, and it caused increased anxiety and stress in children and their parents [23].

The Federal Service for Surveillance over Consumer Rights Protection and Human Well-being have implemented broad consulting of consumers. But at the same time, a number of covered consumers is very insignificant. People also tend to have very low level of trust in food products manufacturers, and it makes the situation even worse. Thus, for example, in 2017 Rospotrebnadzor offered to introduce obligatory marking of food products as per a specific "signal color" system that was meant to help to distinguish between products with low, average, and high contents of sugar, salt, and saturated fats. But when the RPORC conducted a questioning among Russians asking what consequences it could have, $76 \%$ respondents stated it could lead to some unfair manufacturers "giving false information on package thus misleading consumers"7. Overall, awareness about this system was quite low at the moment when the questioning was performed as only $10 \%$ respondents had good knowledge on the initiative of Rospotrebnadzor, and there were only $2 \%$ of those who knew about it among respondents aged 18-24 (see Figure 2).

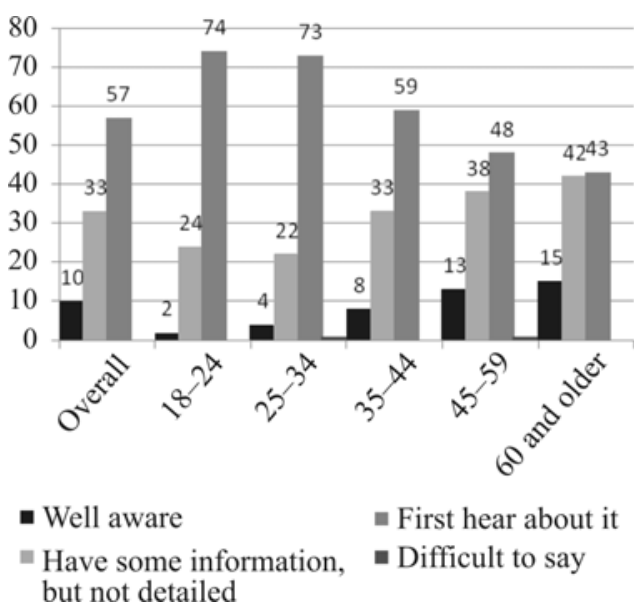

Figure 2. Awareness among Russians about Rospotrebnadzor initiative to mark food products as per "signal color" system (questioning by the RPORC in 2017, in $\%$ from overall number of respondents)

In a situation when institutional trust is low, mass media and experts become very significant subjects in risk communication and they should promote broader discussions about risks. However, at present mass media play a rather negative role in the process as they strive to cover bigger audience, attract more visitors to their web-sites and to increase their ratings. Trying to achieve these goals, mass media either "aggravate" risks or underestimate them especially if an information message is "ordered" by manufacturers, distributors, or sellers of a product. As a results, in April 2018 almost half Russian (41\%) believed that information given in mass media was mostly biased $^{8}$; more than half of respondents (57\%) thought domestic mass media didn't communicate all the information available to them to their audience ${ }^{9}$.

Results of another RPORC questioning revealed that $66 \%$ Russians trusted Russian scientists ${ }^{10}$, and $82 \%$ respondents were proud

\footnotetext{
${ }^{7}$ Food "signal color" system: pro and contra. An initiative all-Russian questioning performed by "RPORC-Sputnik" on December 22-24, 2017 г. [web-source] // RPORC official web-site. - URL: https://wciom.ru/index.php?id=236\&uid=8995 (date of visit October 10, 2018).

${ }^{8}$ Mass media: relevance and performance assessment [Web-source] // POF Official site. - URL:https://fom.ru/SMI-iinternet/14028 (date of visit September 18, 2018).

${ }^{9}$ Confidence in Russian mass media. Are mass media objective when covering events? Should they have more criticizing attitude towards public authorities? [Web-source] // POF Official site. URL: https://fom.ru/SMI-i-internet/12140 (date of visit September 18, 2018).

10 "Express" monthly all-Russian questioning accomplished on August 23, 2015. [Web-source] // RPORC official website. - URL: https://wciom.ru/zh/print_q.php?s_id=1037\&q_id=71653\&date=23.08.2015 (date of visit October 10, 2018).
} 
of Russian science and scientists ${ }^{11}$. Nevertheless, experts are poorly involved into communication with consumers. They mostly provide information to public authorities and don't adapt these data to peculiarities of their perception by population. Experts don't often think about consumers as equal participants in discussions. Besides, experts and public authorities still widely use traditional channels such as brochures, official sites, posters, TV, etc. Specific features of a target audience are rarely given any attention and, as a result, information channels efficiency is rather low. For example, official web-sites of regional authorities dedicated to healthy lifestyle are rather rarely visited. Several dozens of such sites were analyzed in various RF subjects and less than 100 unique visits per a week were detected.

At present there are quite a lot of TV programs about healthy nutrition on Russian TV. They are "To live healthily!" ("The First channel", the program rating is equal to $1.8 \%{ }^{12}$ ), "The most important things" ("Russia" channel, the program rating is $1.75 \%$ ), and "The most useful program" ("REN TV" channel, the program rating is $1 \%$ ). However, these programs are primarily watched by retired people and housewives. TV audience is "ageing" fast. As per data provided by the Federal Agency on Press and Mass Communications of the Russian Federation, TV watchers were averagely aged 48 in 2015 (it was about 44 in 2008) ${ }^{13}$. Data provided by the "Public Opinion" Fund (POF) in spring 2018 revealed that $61 \%$ respondents aged $18-30$ got latest news and information on news websites in the Internet, and $42 \%$ used forums, blogs, and social networks. Only $45 \%$ re- spondents in this age groups mentioned TV as a source of information. But as for people aged $46-60$, TV is a basic source of information for $84 \%$ of them ${ }^{14}$.

Social networks, blogs, micro-blogs, and forums are the most promising communication channels; they require competent involvement of experts on health risks [24]. Videos can be a very interesting form of risk communication including virus videos, photos, creation of "publics", subject web-pages etc., but such activities require competent authors that have not only subject knowledge but also knowledge on communicative technologies basics.

Nowadays experts are not present within the social media system and their place is taken by manufacturers and consumers who are fast and efficient in filling a communicative field up. It is them who become key "informers" and opinion leaders. Thus, a virus video "Chipotle: The Scarecrow" was watched 6.5 million times and downloaded 500,000 times over just two weeks. This short commercial shows awesome food manufacturing processes that incorporate chemical substances. A leading hero is implementing an alternative process of manufacturing and is producing healthy food; he describes it to his audience. Within Chipotle advertising campaign users who have seen the video are offered to download an application into their smartphones and to join a game with its basic target being a search for healthy food. The company explains the Chipotle mission on its official web-site stating that its main goal is to change people's concept of fast food and make them consume "...conventionally cooked highquality food similar to that offered in our restaurants".

\footnotetext{
11 "Express" monthly all-Russian questioning accomplished on June 19, 2016 г. [Web-source] // RPORC official website. - URL: https://wciom.ru/zh/print_q.php?s_id=1082\&q id=75198\&date=19.06.2016 (date of visit October 10, 2018).

${ }^{12}$ Data provided by Mediascope as per the second week of November 2018 for Russian cities with population not less than 100 thousand people [Web-source]. - URL: http://mediascope.net/services/media/media-audience/tv/national-and-regional/audience/?arrFilter_pf $\% 5 \mathrm{BCITY} \% 5 \mathrm{D}=5096 \&$ arrFilter_pf\%5BPERIOD\%5D=12\%2F11\%2F2018+-+18\%2F11\%2F 2018\&arrFilter_pf $\% 5$ BTYPE $\% 5 \mathrm{D}=21 \&$ arrFilter_pf $\% 5 B G E N R E \% 5 \mathrm{D}=42465 \&$ captcha_code $=06 \mathrm{~d} 6 \mathrm{~b} 54075 \mathrm{a} 4 \mathrm{dcce} 5 \mathrm{~d} 4 \mathrm{c} 6$ acabe627d46\&captcha_word= 3F5FD\&set filter $=\mathrm{Y}$ (date of visit October 10, 2018).

${ }^{13} \mathrm{TV}$ in Russia in 2016. Current situation, trends, and prospects of development. Brunch report. - M., 2017. - P. 31.

${ }^{14}$ Mass media: relevance and performance assessment [Web-source] // POF Official site. https://fom.ru/SMI-i-internet/14028 (date of visit October 10, 2018).
} 
"Short videos" have a great potential as a tool for informing food products consumers about health risks as it was proven by a piece of research performed on a sampling made up of 185 Swedish consumers. An experimental group was shown a short video about results of a scientific assessment that focused on health risks related to food safety (natural and artificial food additives). After having seen the video, consumers from the experimental group had authentically better awareness, more positive attitudes towards food products and lower anxiety than consumers from the reference group [25].

Consumers themselves partly fill up social media field with certain information. But bloggers often don't have enough knowledge in the sphere and pursue predominantly personal goals (for example, a blog about "healthy cooking" can be only a way to present oneself in the public space [26]). Research on food blogging performed in Australia by Lofgren $\mathrm{J}$. (2013) revealed that most bloggers didn't have any specialized education in the sphere of catering or medicine. As a result, population tend to have a specific risk assessment that differs from expert judgments and it makes achievement of social consensus more difficult [27].

Institutions that are responsible for distributing information about health risks including food-related ones enjoy great possibilities that are provided by up-to-date communication means via application of social media. When they apply the most popular social networks (Vkontakte, Odnoklassniki, Facebook, Twitter, YouTube, and Instagram) to communicate relevant information to consumers and try to explain complicated data with simple language, it helps to minimize content distortions caused by spreading rumors and to eliminate negative effects in cases when various mass media or unfair manufacturers exploit this subject only to pursue their personal goals. Risk communication via social media can be implemented in variable ways. One of the most relevant ones is to create pages of official communities in Vkontakte, Facebook and other active social networks. Another one is to apply banners (to implement exchange with banners among all official sources of information about health risks, electronic mass media, and famous bloggers). Experts can also "re-orientate" efficient bloggers and use them as "translators" of specific ideas and opinions. The World Health Organization experts have long been treating famous bloggers as "significant agents of influence" ${ }^{15}$.

Therefore, as consumers are basic recipients of food-related risks, one can build efficient risk communications only on the basis of profound examination and insight into specific health risks perception by individuals and population groups.

In addition to targeted informing about risks, it is necessary to study value orientations of consumers, their individual psychological peculiarities, peculiarities of spontaneous information spread via informal channels, parameters of confidence in information carriers etc. It is advisable to perform specific sociological research for building up risk profiles and determining peculiarities of risk perception by specific contingents as it will allow to provide a solid base for efficient risk communications.

Providing efficient risk communications in food safety sphere requires the following:

- to create standard and methodological ground (methodical guidelines on informing about health risks that include schemes for information spreading among various consumer groups and highlight the most suitable forms and channels; samples of information materials that determine basic contents of a message (depending on a channel format) and its design; rules that allow to built

\footnotetext{
${ }^{15}$ How to organize work with concerned parties [Web document // The WHO Regional office for Europe official site. - URL: http://www.euro.who.int/_data/assets/pdf_file/0009/373248/vss-stakeholder-management-rus.pdf (date of visit October 10, 2018).
} 
risk communications correctly with application of Internet resources; algorithms for building up feedback and involvement of all communication subjects into risk management);

- to provide monitoring of risk perception by various population groups (sociological research via questioning, focus groups, etc.);

- to organize interaction between risk communication subjects in order to increase their communicative competence and exchange of experience (scientific-practical conferences, skills development, workshops, webinars, etc.).

All the above-mentioned activities are to be performed with involvement of experts from the bodies and institutions of the Federal Service for Surveillance over Consumer Rights Protection and Human Well-being, the RF Public Healthcare Ministry, The Federal Service for Veterinary and Phytosanitary Surveillance, scientific research organizations, educational establishments, etc.

To sum up, we can state that there are the following ways to build up an efficient communications system: increased information activity and interest of the population in food safety matters; formation of not only great awareness about risks but also a persis- tent attitude towards self-preserving behavior in population; further development of the state system for risk communications in the sphere of population health and food safety. A most significant aspect here is to apply information channels that are in demand by a target audience as wide as its only possible (social media can be quite a good example here) and to create favorable conditions for public discussions on risks. Tactical tasks here are methodical support provided for all the concerned parties as regards forms and ways to communicate information about health risks that are relevant for a target audience. More active involvement of experts into a constructive dialogue about risks is a significant tool for increasing risk communications efficiency. And as population tend to confide in scientists, experts, and doctors more than in public agents, representatives from these groups should play a more significant social role within efficient risk communication systems.

Funding. The research was not granted any sponsor support.

Conflict of interests. The authors state there is no any conflict of interests.

\section{References}

1. Khotimchenko S.A., Gmoshinskii I.V., Tutel'yan V.A. Problem of safety provision of nanodimensional objects for human health. Gigiena i sanitariya, 2009, no. 5, pp. 7-10 (in Russian).

2. Tutel'yan V.A. Obespechenie bezopasnosti genno-inzhenerno-modifitsirovannykh organizmov dlya proizvodstva pishchevykh produktov [Ensuring the safety of genetically modified organisms for food production]. Vestnik Rossiiskoi akademii nauk, 2017, vol. 87, no. 4, pp. 342-347 (in Russian).

3. Risk communication applied to food safety handbook. Rome, FAO/WHO, 2016. Available at: http://www.fao.org/3/a-i5863e.pdf (10.10.2018).

4. Improving Food Safety and Risk Communication / in Enhancing Food Safety. The Role of the Food and Drug Administration.Washington, DC: The National Academies Press, 2010, 588 p. Available at: https://doi.org/10.17226/12892 (10.10.2018).

5. Barg A.O. Risk-communication in the sphere of health as a sort of social communication. Diskussiya, 2017, vol. 75, no. 1, pp. 50-55 (in Russian).

6. Andriyanova E.A., Chernyshkova E.V., Sidel'nikov S.A., Dolgova E.M. Risk-communication as the factor of medicine institutionalization. Sovremennye issledovaniya sotsial'nykh problem (elektronnyi nauchnyi zhurnal), 2017, vol. 8, no. 3-1, pp. 69-79 (in Russian).

7. Biblin A.M., Akhmatdinov R.R. Risk-kommunikatsiya pri obespechenii radiatsionnoi bezopasnosti: doverie naseleniya $\mathrm{k}$ internetu kak istochniku informatsii o radiatsionnoi obstanovke [Risk communication in ensuring radiation safety: public confidence in the Internet as a source of 
information on radiation conditions]. Fundamental'nye i prikladnye aspekty analiza riska zdorov'yu naseleniya: materialy vserossiiskoi nauchno-prakticheskoi internet-konferentsii molodykh uchenykh i spetsialistov Rospotrebnadzora. In: A.Yu. Popova, N.V. Zaitseva eds. Perm, 2017, pp. 263-274 (in Russian).

8. Kher S.V., De Jonge J., Wentholt M.T.A., Deliza R., de Andrade J.C., Cnossen H.J., Luijckx N.B.L., Frewer L.J. Consumer perceptions of risks of chemical and microbiological contaminants associated with food chains: a cross-national study. International Journal of Consumer Studies, 2011, vol. 37, no. 1, pp. 73-83.

9. Giles E.L., Kuznesof S., Clark B., Hubbard C., Frewer, L.J. Consumer acceptance of and willingness to pay for food nanotechnology: a systematic review. Journal of nanoparticle research: an interdisciplinary forum for nanoscale science and technology, 2015, vol. 17, no. 12, pp. 467.

10. Frewer L.J., Fischer A.R.H., Brennan M., Bánáti D., Lion R., Meertens R.M., Rowe G., Siegrist M., Verbeke W., Vereijken C. M.J.L. Risk/Benefit Communication about Food - A Systematic Review of the Literature. Critical Reviews in Food Science and Nutrition, 2016, vol. 56, no. 10, pp. 1728-1745. DOI: 10.1080/10408398.2013.801337

11. Fischer A.R., De Jong A.E., Van Asselt E.D., De Jonge R., Frewer L.J., Nauta, M.J. Food safety in the domestic environment: an interdisciplinary investigation of microbial hazards during food preparation. Risk Analysis, 2007, vol. 27, no. 4, pp. 1065-1082.

12. Van Kleef E., Ueland, Ø., Theodoridis G., Rowe G., Pfenning U., Houghton J., van Dijk H., Chryssochoidis G., Frewer L.J. Food risk management quality: consumer evaluations of past and emerging food safety incidents. Health, Risk and Society, 2009, vol. 11, no. 2, pp. 1-27.

13. Lusk J.L., Briggeman B. Food values. American journal of agricultural economics, 2009, vol. 91, no. 1, pp. 184-196. 10.1111/j.1467-8276.2008.01175.x

14. Martínez-Ruiz M.P., Gómez-Cantó C.M. Key External Influences Affecting Consumers' Decisions Regarding Food. Frontiers in psychology, 2006, vol. 7, p. 1618. DOI: 10.3389/fpsyg.2016.01618

15. Yegiyan N.S., Bailey R.L. Food as Risk: How Eating Habits and Food Knowledge Affect Reactivity to Pictures of Junk and Healthy Foods. Health communication, 2016, vol. 31, no. 5, pp. 635-642. DOI: 10.1080/10410236.2014.987098.

16. Hooker C., Capon A., Leask J. Communicating about risk: strategies for situations where public concern is high but the risk is low. Public health research and practice, 2017, vol. 27, no. 1, pp. e2711709. DOI: 10.17061/phrp2711709

17. MacGregor D.G., Slovic P., Morgan M.G. Perception of risks from electromagnetic fields: a psychometric evaluation of a risk-communication approach. Risk analysis, 1994, vol. 14, no. 5, pp. 815-828.

18. Wu L., Zhong Y., Shan L., Qin W. Public risk perception of food additives and food scares. The case in Suzhou, China. Appetite, 2013, vol. 70, pp. 90-98. DOI: 10.1016/j.appet.2013.06.091.

19. You M., Ju Y. A Comprehensive Examination of the Determinants for Food Risk Perception: Focusing on Psychometric Factors, Perceivers' Characteristics, and Media Use. Health communication, 2017, vol. 32, no. 1, pp. 82-91.

20. Tiozzo B., Mari S., Ruzza M., Crovato S., Ravarotto L. Consumers' perceptions of food risks: A snapshot of the Italian Triveneto area. Appetite, 2017, vol. 111, pp. 105-115. DOI: 10.1016/j.appet.2016.12.028

21. Stensgaard A., DunnGalvin A., Nielsen D., Munch M., Bindslev-Jensen C. Green, Yellow, and Red risk perception in everyday life - a communication tool. Allergy, 2017, vol. 72, no. 7, pp. 1114-1122. DOI: 10.1111/all.13095

22. Cui K., Shoemaker S.P. Public perception of genetically-modified (GM) food: A Nationwide Chinese Consumer Study. npj Science of Food, 2018, vol. 2. DOI: 10.1038/s41538-018-0018-4

23. Hanna H.J., Emmanuel J., Naim S., Umasunthar T., Boyle R.J. Community healthcare professionals overestimate the risk of fatal anaphylaxis for food allergic children. Clinical and experimental allergy, 2016, vol. 46, no. 12, pp. 1588-1595. DOI: 10.1111/cea.12846

24. Overbey K.N., Jaykus L.A., Chapman B.J. A Systematic Review of the Use of Social Media for Food Safety Risk Communication. Journal of food protection, 2017, vol. 80, no. 9, pp. 1537-1549. DOI: 10.4315/0362-028X.JFP-16-345 
25. Bearth A., Cousin M.E., Siegrist M. «The Dose Makes the Poison»: Informing Consumers About the Scientific Risk Assessment of Food Additives. Risk analysis, 2016, vol. 36, no. 1, pp. 130-144. DOI: $10.1111 /$ risa. 12410

26. Ramonova T.A. Kulinarnyi blog kak forma samoprezentatsii [Culinary blog as a form of self-presentation]. Istoriya edy $i$ traditsii pitaniya narodov mira: materialy II Mezhdunarodnogo simpoziuma. Moscow, MGU imeni M.V. Lomonosova; Tsentr po izucheniyu vzaimodeistviya kul'tur; Akademiya gastronomicheskoi nauki i kul'tury, 2016, pp. 373-377 (in Russian).

27. Lofgren J. Food Blogging and Food-related Media Convergence. M/C Journal, 2013, vol. 16, no. 3. Available at: http://journal.media-culture.org.au/index.php/mcjournal/article/view/638 (16.10.2018).

May I.V., Lebedeva-Nesevrya N.A., Barg A.O. Strategy and tactics for building up efficient risk-communications in the sphere of food products safety. Health Risk Analysis, 2018, no. 4, pp. 105-113. DOI: 10.21668/health.risk/2018.4.12.eng

Received: 22.10 .2018

Accepted: 14.12 .2018

Published: 30.12 .2018 
UDC $316.77+613.2$

DOI: $10.21668 /$ health.risk/2018.4.13.eng

Read

online

\section{HOW TO EFFECTIVELY COMMUNICATE RISKS TO DIVERSE CONSUMERS}

\section{Petrova, R. Garcia-Retamero}

Mind, Brain and Behavior Research Center, University of Granada, 36-38 Calle Real de Cartuja, Granada, 18071, Spain

The article outlines how to efficiently communicate risks described in numerical values to consumers. The issue is vital and its relevance is related to communication that applies numeric values is an essential part of informing consumers about hazards and advantages of food products; however, a lot of consumers have difficulty perceiving digital information about risks due to various reasons. Consequently, such people assess risks inadequately and can't make well justified decisions based on quantitative information. The authors explain that to remove numerical information and to replace it with verbal description is not advisable as it doesn't allow to solve an issue of efficient risk communication. They also give examples that illustrate how wrong communication tactics can lead to risks aggravation or underestimation. The authors apply certain propositions to prove efficiency of tested risk communication formats, such as standard categories, visual aids, conventional symbols, etc. It was detected that visual aids, or graphic images of information on risks, can eliminate a lot of problems and result in much better understanding of risks and decisions among diverse people. Such means are quite efficient when it comes to people with limited abilities related to perception of linguistic and numerical information, elderly people, highly educated people and population in general. The authors also give some positive examples on how information was adapted for diverse consumers. They come to a conclusion that well-thought-out and transparent risk communication formats that incorporate natural cognitive strategies can make risk communications much easier. Better understanding, in its turn, often leads to conscious decision making by consumers and health-oriented decisions, intentions, and behavior.

Key words: consumer products, risk assessment, health risks, informing, risk communications.

One can attract customers' attention using variable traditional and up-to-date communication channels. However, the challenge remains regarding how to communicate risk effectively to diverse audiences, especially when it comes to communicating numerical information. A growing body of research shows that many consumers have difficulty understanding numerical information about risk but such data are often an essential part in informing about risks. This paper dwells on various strategies that can help to improve risk communications regarding both individual consumers and basic decision making (for example, risk comprehension and risk perception). The research outlines formats that can either distort or improve perception and comprehension. We recommend several tools that can help to reveal people who can get wrong comprehension about risks and suggest certain approaches to creation of materials that inform about risks and are adapted for a specific audience.

Risk communications with numerical information are an essential part of informing consumers about hazards or advantageous of food products. The increased data gathering and enhanced analytical capabilities of today make reliable risk assessment available and the results should be communicated to consumers. The spread of technology and the Internet gives us the opportunity to easily reach consumers through various traditional and modern communication channels. However, the challenge remains regarding how to communicate risk effectively to diverse audiences. A growing body of research shows that many consumers have low risk literacy - they have difficulty understanding numerical information about risk. So, they can't make informed decisions based on numerical information. Thus, as per Galesic research [1], performed on repre-

(C) Petrova D., Garcia-Retamero R., 2018

Dafina Petrova - Candidate of Medical Science, postdoctoral researcher (e-mail: dafinapetrova@ugr.es; tel.: +34958245171; ORCID: https://orcid.org/0000-0002-0346-6776).

Rocio Garcia-Retamero - Candidate of Psychology Science, associate professor of experimental psychology (e-mail: rretamer@ugr.es; tel.: +34958245171; ORCID: https://orcid.org/0000-0001-9140-8519). 
sentative national samplings, about a third of the United States and Germany citizens cannot perform basic probability operations such as transforming proportions to percentages; as a results, they do not know which risk is bigger: 1 in 100,1 in 1000, or 1 in 10 .

Avoiding numerical information and replacing it with verbal labels is not a viable solution to this problem. Research shows that using verbal labels to describe risks such as "rare", "frequent", or "common" results in very variable and often inaccurate interpretations by communication recipients [2]. Fortunately, research in risk communication has generated several important insights that can help us communicate risks to consumers in an effective and transparent way. In particular, research shows that low risk literacy is not necessarily caused by people's cognitive limitations but is greatly influenced by a specific format of risk communication [3]. Here we briefly summarize several risk communication strategies that can help improve risk communication.

Avoid some risk communication formats and use recommended alternatives instead. Suppose that experts have detected salmonella in 3\% of popular brand bagged salads currently on the market. When communicating this risk to consumers, experts caution against using what has been termed the 1-out of-X format (i.e., 1 out of 33 salads on the market has been contaminated) [4]. Compared to other formats (percentages or proportions out of 100), the 1-out of-X format results on average in more worry and heightened risk estimates, so it may unnecessarily scare consumers [5]. An alternative option would be to communicate the risk using percentages. In this case, special attention should be paid to the reference class. To illustrate, research shows that if we communicate to consumers that "The risk of contaminated products is 3\%", about a third of consumers may mistakenly interpret this as for instance " $3 \%$ of the leaves in each bagged salad are contaminated" [6]. In contrast, if we specify the reference class (i.e., 3\% of bagged salad packages currently on the market are contaminated) we would avoid this confusion.
The size of the reference class is also important, because it may convey information about the reliability of estimates (more reliable with larger sample sizes) or the total number of persons or units at risk.

Special care should be taken also when comparing groups with different sizes. For instance, suppose that we communicate to consumers that contaminated salads have been found in 3 out of 50 stores in municipality A and 8 out of 200 stores in municipality B. Research shows that up to half of communication recipients may mistakenly infer that the risk is greater in municipality B (4\%) than in municipality A (6\%). This is because people often focus on the numerator in a fraction (3 vs. 8 ) and ignore or pay less attention to the denominator (the total number of stores in each municipality, 50 vs. 200) [7, 8]. To avoid confusion, experts recommend transforming the fractions using the same denominator (6 in 100 stores in municipality A and 4 in 100 stores in municipality B). When that is not possible or desirable, visual aids can help (see Figure 1). The most popular visual aids used to communicate risk information include bar graphs, line graphs, and icon arrays.

Use well-designed visual aids to boost comprehension. A growing body of research shows that visual aids - graphical displays of risk information - can solve numerous problems discussed above and robustly improve risk comprehension and decisions in diverse individuals (for a review see [9]). Visual aids have been effective in individuals with limited linguistic and numeric abilities, elderly individuals, highly educated professionals, and population in general. However, not all visual aids are equally effective. In order to inform consumers, they need to be welldesigned - transparent and with well defined elements that "accurately and clearly represent the relevant information by making partto-whole relationships in the data visually available" [9]. In a recent systematic review article, Garcia-Retamero and Cokely [10] offer useful evidence-based guidelines regarding how to design effective and transparent visual aids. As we can see in Figure 1, each 
square represents one store. Similar displays have been shown to facilitate risk comparisons in different contexts $[7,8]$.

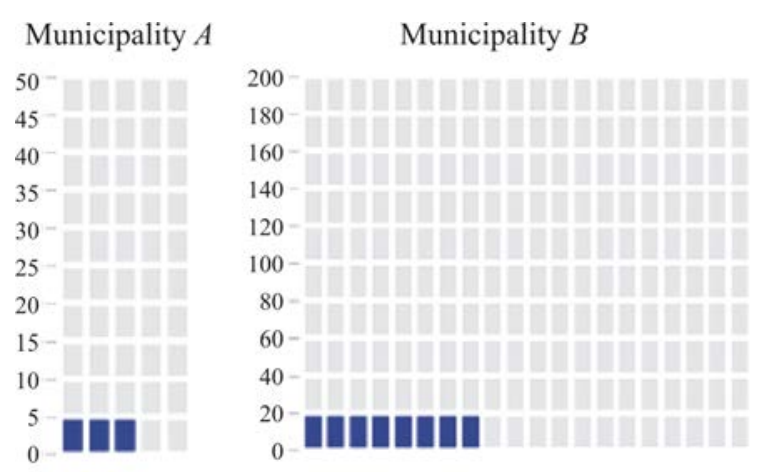

Stores that sold contaminated produce.

Stores that did NOT sell contaminated produce.

Figure 1. An example of icon arrays displaying the proportion of stores that may have sold contaminated produce in two municipalities with a different number of stores.

Use validated screening tools to optimize risk communication. Visual aids are powerful tools but unfortunately, they are not equally effective for everyone. In particular, visual aids will help consumers as long as they have a moderate level of graph literacy that is a skill that allows them to extract data and meaning from graphical representations of quantitative information [11-13]. The efficiency of different risk communication strategies may also depend on the statistical numeracy of consumers, i.e., their ability to understand and use mathematical expressions of probability [14]. Numeracy influences not only the extent to which consumers understand different risk communication formats, but also their preference for receiving quantitative information [15-17]. This suggests that tailoring information on the individual or average population level can increase risk communication efficiency (see [18] for an example from the medical domain). There are several validated tools that can help to adapt risk communication to individual recipients or on average to the population level. The new Subjective Graph Literacy scale assesses people's selfreported ability to process and use graphically presented information [13]. In only one minute, it provides a reliable and valid assessment of consumers' skills and risk communication preferences, making it especially efficient and user-friendly. There is also a more extensive scale measuring Objective Graph Literacy [11] that would be useful for more researchoriented applications. This scale uses test-like items and is a powerful predictor of performance on diverse graph-related tasks in populations with different cultural, educational, and demographic backgrounds [12].

Several measures of numeracy exist, including the Subjective Numeracy Scale [17] that is a useful addition to the Subjective Graph Literacy Scale. To measure objective numeracy with math-like questions one can choose among several instruments of varying length and difficulty $[14,19,20]$. For instance, the Berlin Numeracy Test (see riskliteracy.org) is among the most efficient stand-alone assessments of numeracy, risk literacy, and general decision making skill [21]. It provides a reliable assessment in 2-3 minutes and is suitable for use with educated samplings from diverse countries and cultures (e.g., college students, computer-literate adults, experts).

Conclusions. High level of education does not guarantee comprehension of risk communications as even some highly educated, experienced professionals misunderstand important risk communications in their field of expertise $[18,22]$. Subtle differences in risk communication formats and misunderstanding of risk statistics can have significant effects on comprehension and subsequent decisions and behavior. Fortunately, there are solutions to the problem: well-designed, transparent risk communication formats that make use of people's natural cognitive strategies can facilitate risk communication. Improved comprehension in turn often leads to informed decision making by consumers and health-oriented decisions, intentions, and behavior [10, 23-25].

Funding. The research was not granted any sponsor support.

Conflict of interests. The authors state there is no any conflict of interests. 


\section{References}

1. Galesic M., Garcia-Retamero R. Statistical numeracy for health: A cross-cultural comparison with probabilistic national samples. Archives of Internal Medicine, 2010, vol. 170, no. 5, pp. 462-468. DOI: 10.1001/archinternmed.2009.481

2. Lipkus I.M. Numeric, Verbal, and Visual Formats of Conveying Health Risks: Suggested Best Practices and Future Recommendations. Medical Decision Making, 2007, vol. 27, pp. 696-713.

3. Garcia-Retamero R., Galesic M. Transparent communication of health risks: Overcoming cultural differences. New York, Springer, 2013, 269 p. DOI: 10.1007/978-1-4614-4358-2

4. Sirota M., Juanchich M., Kostopoulou O., Hanak R. Decisive evidence on a smaller-than-youthink phenomenon: revisiting the "1-in-X" effect on subjective medical probabilities. Medical Decision Making, 2014, vol. 34, pp. 419-429.

5. Pighin S., Savadori L., Barilli E., Cremonesi L., Ferrari M., Bonnefon J. The 1-in-X Effect on the Subjective Assessment of Medical Probabilities. Medical Decision Making, 2011, vol. 31, pp. 721-729.

6. Gigerenzer G., Galesic M. Why do single event probabilities confuse patients? BMJ: British Medical Journal, 2012, vol. 344, pp. e245. DOI: 10.1136/bmj.e245

7. Garcia-Retamero R., Galesic M., Gigerenzer G. Do icon arrays help reduce denominator neglect? Med Decis Making, 2010, vol. 30, pp. 672-684.

8. Okan Y., Garcia-Retamero R., Cokely E.T., Maldonado A. Individual differences in graph literacy: overcoming denominator neglect in risk comprehension. J. Behav. Decis. Making., 2012, vol. 25, pp. 390-401.

9. Garcia-Retamero R., Cokely E.T. Communicating health risks with visual aids. Curr. Dir. Psychol. Sci., 2013, vol. 22, pp. 392-399.

10. Garcia-Retamero R., Cokely E.T. Designing visual aids that promote risk literacy: A systematic review of health research and evidence-based design heuristics. Human Factors, 2017, vol. 59, no. 4, pp. 582-627. DOI: 10.1177/0018720817690634

11. Galesic M., Garcia-Retamero R. Graph literacy: a cross-cultural comparison. Med. Decis. Making., 2011, vol. 31, pp. 444-457.

12. Garcia-Retamero R., Petrova D., Feltz A., Cokely E.T. Measuring Graph Literacy: A Systematic Review and Meta Analysis. Oxford University Press. Available at: http://oxfordre.com/communication/ view/10.1093/acrefore/9780190228613.001.0001/acrefore-9780190228613-e-302 (16.04.2017).

13. Garcia-Retamero R., Cokely E.T., Ghazal S., Joeris A. Measuring graph literacy without a test: A brief subjective assessment. Medical Decision Making, 2016, vol. 36, pp. 854-867.

14. Lipkus I.M., Samsa G., Rimer B.K. General Performance on a Numeracy Scale among Highly Educated Samples. Medical Decision Making, 2001, vol. 21, pp. 37-44.

15. Trevena L.J., Zikmund-Fisher B.J., Edwards A., Gaissmaier W., Galesic M., Han P.K. [et al]. Presenting quantitative information about decision outcomes: a risk communication primer for patient decision aid developers. BMC medical informatics and decision making, 2013, vol. 13, pp. S7.

16. Garcia-Retamero R., Galesic M. Communicating Treatment Risk Reduction to People With Low Numeracy Skills: A Cross-Cultural Comparison. Am. J. Public. Health., 2009, vol. 99, pp. 2196-2202.

17. Fagerlin A., Zikmund-Fisher B.J., Ubel P.A., Jankovic A., Derry H.A., Smith D.M. Measuring numeracy without a math test: development of the Subjective Numeracy Scale. Med. Decis. Making, 2007, vol. 27, pp. 672-680.

18. Petrova D., Kostopoulou O., Delaney B., Cokely E.T., Garcia-Retamero R. Strengths and gaps in physicians' risk communication: A scenario study of the influence of numeracy on cancer screening communication. Medical Decision Making, 2018, vol. 38, no. 3, pp. 355-365. DOI: 10.1177/0272989X17729359

19. Schwartz L.M., Woloshin S., Black W.C., Welch H.G. The role of numeracy in understanding the benefit of screening mammography. Ann Int. Med., 1997, vol.127, pp. 966-972. 
20. Weller J.A., Dieckmann N.F., Tusler M., Mertz C., Burns W.J., Peters E. Development and testing of an abbreviated numeracy scale: A rasch analysis approach. J. Behav. Decis. Making., 2013, vol. 26, pp. 198-212.

21. Cokely E.T., Galesic M., Schulz E., Ghazal S., Garcia-Retamero R. Measuring Risk Literacy: The Berlin Numeracy Test. Judg Decis. Making., 2012, vol. 7, pp. 25-47.

22. Garcia-Retamero R., Cokely E.T., Wicki B., Joeris A. Improving risk literacy in surgeons. Patient Educ Couns, 2016, vol. 99, pp. 1156-1161.

23. Petrova D., Garcia-Retamero R., Cokely E.T. Understanding the harms and benefits of cancer screening: a model of factors that shape informed decision making. Med. Decis. Making., 2015, vol. 35, pp. $847-858$.

24. Petrova D., Garcia-Retamero R., Catena A., van der Pligt J. To screen or not to screen: What factors influence complex screening decisions? J. Exp. Psychol. Appl., 2016, vol. 22, pp. 247-260.

25. Garcia-Retamero R., Cokely E.T. The influence of skills, message frame, and visual aids on prevention of sexually transmitted diseases. J. Behav. Decis. Making., 2014, vol. 27, pp. 179-189.

Petrova D., Garcia-Retamero R. How to effectively communicate risks to diverse consumers. Health Risk Analysis, 2018, no. 4, pp. 114-118. DOI: 10.21668/health.risk/2018.4.13.eng

Received: 13.09 .2018

Accepted: 17.12 .2018

Published: 30.12.2018 
UDC 614.777; 664.001.25(07)

DOI: $10.21668 /$ health.risk/2018.4.14.eng

Read

online

\title{
GENETICALLY MODIFIED FOOD PRODUCTS: DEVELOPMENT OF SAFETY ASSEESSMENT SYSTEM IN RUSSIA
}

\author{
N.V. Tyshko, E.O. Sadykova \\ Federal Research Center for Nutrition, Biotechnology and Food Safety, 2/14 Ust'inskiy lane, Moscow, 109240, \\ Russian Federation
}

The paper gives an overview of basic approaches to assessing safety of genetically modified organisms (GMOs) that are used in food products manufacturing. It contains data on overall volumes of GMOs production in the world and outlines basic trends in development of GMOs safety assessment in the Russian Federation.

In Russia a system for GMOs safety assessment was first created on the basis of domestic experience accumulated via medical and biological research on protein products of microbiological synthesis taking into account all the approaches that existed in the world. A combined algorithm was substantiated; the algorithm includes examinations of GMOs properties and obligatory examinations in vivo: toxicological ones performed via a chronic experiment on rats; allergic ones performed via a modeling experiment on rats; immunologic and genotoxic ones performed via experiments on mice. The system was developed further as, first of all, there was a search for biomarkers that allow to make toxicological research more sensitive; secondly, reproductive functions and offspring development were studied. Experts confirmed that parameters of apoptosis activity could be used as biomarkers; reproductive functions and offspring development were studied over several generations; the most sensitive parameters of rats' reproductive functions were determined under modeled toxic exposure; experts examined an influence exerted on reproductive functions by the seasonal factor and studied prenatal and postnatal development of offspring. New requirements to conducting medical and biological assessment of GMOs were formulated. Starting from 2011, reproductive toxicity of GMOs has been an obligatory part in the state certification of new GM products.

Requirements to safety assessment of GMOs with combined features have been developed on the basis of domestic and international experience; these requirements correspond to regulation principles for GMOs application in food products.

Key words: genetically modified organisms, food products, safety assessment, biological markers.

Scientific developments in molecular biology and genetic engineering have allowed to create new selection techniques based on targeted modifications of plants genomes. From 1996 to 2016 areas where genetically modified crops are being grown have increased worldwide by more than 100 times and have achieved a total square equal to 185.1 million ha $[1$, p. 2$] ; 28$ various plants have GM analogues and overall number of existing GM lines is 495,462 out of them being agricultural crops (Table 1) [2]. Basic GM cultures are soya with its crops being grown on 91.4 million ha (49\% from the total square of GMO crops and $78 \%$ from the total area where soya crops are grown); corn grown on 60.6 million ha $(33 \%$ and $33 \%$ respectively); cotton, 22.3 million ha (12\% and $64 \%$ respectively); rape, 8.6 million ha (5\% and $24 \%$ respectively) [1, p. 90].

Food and forage manufactured from genetically modified vegetable organisms have appeared on the market and it has led to a necessity to develop approaches to complex assessment of such products, first of all, safety assessment. A procedure for assessing safety of GM food was first introduced in 90ties last century; apart from analyzing properties of a donor-organism and a recipient-organism, a technique for genetic modification, and characteristics of a newly obtained organism, it assessed safety of a new protein expressed on the basis of recombinant DNA and equivalence of GMO chemical structure and its traditional analogue

(C) Tyshko N.V., Sadykova E.O., 2018

Nadezhda V. Tyshko - Candidate of Medical Sciences, Head of the Laboratory for Safety Assessment of Biological Technologies and New Food Sources (e-mail: tnv@ion.ru; tel.: +7 (495) 698-53-64; ORCID: https://orcid.org/0000-0002-8532-5327).

Elvira O. Sadykova - Candidate of Biological Sciences, Senior Researcher at the Laboratory for Safety Assessment of Biological Technologies and New Food Sources (e-mail: seo@ion.ru; tel.: +7 (495) 698-53-64; ORCID: https://orcid.org/0000-0001-5446-5653). 
Table 1

Plants and cultures with GM analogues (as per July 2017)

\begin{tabular}{|c|c|c|c|}
\hline No. & Culture & $\begin{array}{l}\text { Number } \\
\text { of GM lines }\end{array}$ & $\begin{array}{c}\text { Number of lines with combined features } \\
\text { obtained via hybridization }\end{array}$ \\
\hline \multicolumn{4}{|c|}{ Agricultural plants } \\
\hline 1 & Aubergine & 1 & - \\
\hline 2 & Beans & 1 & - \\
\hline 3 & Melon & 2 & - \\
\hline 4 & Marrow & 2 & - \\
\hline 5 & Potato & 47 & - \\
\hline 6 & Corn & 233 & $\begin{array}{c}187 \text {, out of them } 63(2 x), 67(3 x), 41(4 x) \text {, } \\
12(5 x), 4(6 x)\end{array}$ \\
\hline 7 & Flax & 1 & - \\
\hline 8 & Papaya & 4 & - \\
\hline 9 & Wheat & 1 & - \\
\hline 10 & Rape & 43 & 24, out of them $12(2 x), 2(3 x)$ \\
\hline 11 & Rice & 7 & - \\
\hline 12 & Sugar beet & 3 & - \\
\hline 13 & Sugar cane & 4 & - \\
\hline 14 & Sweet pepper & 1 & - \\
\hline 15 & Plum & 1 & - \\
\hline 16 & Soya & 36 & 11, out of them $9(2 x), 1(3 x), 1(4 x)$ \\
\hline 17 & Tomato & 11 & - \\
\hline 18 & Cotton & 58 & 23, out of them $12(2 x), 7(3 x), 4(4 x)$ \\
\hline 19 & Chicory & 3 & - \\
\hline 20 & Apple & 3 & - \\
\hline \multicolumn{4}{|c|}{ Other plants } \\
\hline 21 & Cloves & 19 & - \\
\hline 22 & Lucerne & 5 & $2(2 x)$ \\
\hline 23 & Petunia & 1 & - \\
\hline 24 & Bent & 1 & \\
\hline 25 & Rose & 2 & - \\
\hline 26 & Tobacco & 2 & - \\
\hline 27 & Poplar & 2 & - \\
\hline 28 & Gum tree & 1 & - \\
\hline
\end{tabular}

\begin{tabular}{|c|c|c|c|}
\hline No. & Culture & $\begin{array}{l}\text { Number } \\
\text { of GM lines }\end{array}$ & $\begin{array}{c}\text { Number of lines with combined features } \\
\text { obtained via hybridization }\end{array}$ \\
\hline \multicolumn{4}{|c|}{ Agricultural plants } \\
\hline 1 & Aubergine & 1 & - \\
\hline 2 & Beans & 1 & - \\
\hline 3 & Melon & 2 & - \\
\hline 4 & Marrow & 2 & - \\
\hline 5 & Potato & 47 & - \\
\hline 6 & Corn & 233 & $\begin{array}{l}\text { 187, out of them } 63(2 x), 67(3 x), 41(4 x), \\
12(5 x), 4(6 x)\end{array}$ \\
\hline 7 & Flax & 1 & - \\
\hline 8 & Papaya & 4 & - \\
\hline 9 & Wheat & 1 & - \\
\hline 10 & Rape & 43 & 24, out of them $12(2 x), 2(3 x)$ \\
\hline 11 & Rice & 7 & - \\
\hline
\end{tabular}


Genetically modified food products: development of safety asseessment system in Russia

\begin{tabular}{|l|l|c|c|}
\hline 12 & Sugar beet & 3 & - \\
\hline 13 & Sugar cane & 4 & - \\
\hline 14 & Sweet pepper & 1 & - \\
\hline 15 & Plum & 1 & - \\
\hline 16 & Soya & 36 & 11, out of them 9 (2x), 1 (3x), 1 (4x) \\
\hline 17 & Tomato & 11 & 23, out of them 12 (2x), 7 (3x), 4 (4x) \\
\hline 18 & Cotton & 58 & - \\
\hline 19 & Chicory & 3 & - \\
\hline 20 & Apple & 3 & - \\
\hline \multicolumn{4}{|c|}{ Other plants } \\
\hline 21 & Cloves & 19 & - \\
\hline 22 & Lucerne & 5 & - \\
\hline 23 & Petunia & 1 & - \\
\hline 24 & Bent & 1 & - \\
\hline 25 & Rose & 2 & - \\
\hline 26 & Tobacco & 2 & - \\
\hline 27 & Poplar & 2 & - \\
\hline 28 & Gum tree & 1 & \\
\hline
\end{tabular}

as per basic macro- and micro-nutrients, minor substances, anti-nutrients, natural and anthropogenic contaminants, and characterized technological parameters of GM vegetable raw materials [3, p. $30-39 ; 4$, p. $10-13 ; 5$, p. 6-9; 6, p. 4-11] as well. This approach to GMO assessment underlies national systems that nowadays exist in different countries all over the world.

A Russian system for GMO safety assessment was first created in 1995-1996. The system was developed on the basis of domestic experience in medical and biological research performed on protein products of microbiological synthesis [7, p. 59-70], as well as taking into account existing international approaches $[3$, p. 30-39; 4, p. 10-13; 5, p. 6-9;6, p. 4-11]. It was a combined algorithm that, apart from the above mentioned examinations of GMO properties, included an obligatory set of examinations in vivo: toxicological ones performed as a chronic experiment on rats; allergic ones performed as a model experiment on rats; immunological and genotoxic ones performed as experiments on mice (MG 2.3.2.970-00, 2000) $)^{1}$. Starting from safety assessments performed for the first GM lines that were subject to state registration the system has been recognized on the international level and has been qualified as the strictest one among similar systems applied for assessing GMO safety. Experience in GMO examinations accumulated in Russia over 1999-2005 confirmed that the approach was quite efficient; however, development of toxicological examinations methodology as well as a stable trend for a growth in squares of GM agricultural crops and GM lines and plants with GM analogues that appeared at that time made it necessary to develop the system for safety assessment further and in an advance mode.

There are some promising lines of development for the GMO safety assessment; first of all, it is searching for biological markers that allow to increase sensitivity of toxicological examinations; secondly, examination of reproductive functions and offspring development. Accomplished examinations confirmed that it was possible to apply parameters of apoptosis activity as biomarkers $[8$, p. $35 ; 9$, p. $997 ; 10$, p. $194 ; 11$, p. $213 ; 12$, p. $172 ; 13$, p. 203], and reproductive functions and offspring development in subsequent generations

${ }^{1}$ MG 2.3.2.970-00. medical and biological assessment of food products obtained from genetically modified sources: Methodical Guidelines [web-source] // KODEKS: an electronic fund of legal and reference documentation. - URL: http://docs.cntd.ru/document/1200006955 (date of visit July 05, 2018). 
were studied as well, and it allowed to determine the most sensitive parameters of rats' reproductive function under model toxic exposure and to study influence exerted by seasonality factor on the reproductive function, prenatal and postnatal development of offspring $[14$, p. $45-47 ; 15$, p. $24 ; 16$, p. 259 ; 17 , p. 334-339;18, p. $73 ; 19$, p. 36-42]. Eventually, new requirements to medical and biological GMO assessment were formulated and fixed in the methodical guidelines 2.3.2.2306-0 $7^{2}$. Starting from 2011, assessment of GMP reproductive toxicity has been obligatory within state registration procedures for new GM lines.

According to an existing non-official classification, nowadays vegetable GMOs include the first generation cultures, as well as cultures belonging to the second, third, and subsequent ones. GM cultures of the first generation distributed on the world food market and created in 1994-2004 have better agronomic properties such as resistance to pesticides, pests, viruses, fungal infections, and new consumer properties. In the early 2000 s it was assumed [20, p. 849-851] the GM cultures of the second and subsequent generations, apart from improved agronomic properties, would have longer shelf life, greater nutrient value and better taste; they would be free of allergens and able to produce immune preparations and medications; their blooming and fruiting periods would be changed as well as shapes and quantities of their fruits; their photosynthesis would be more efficient; they would produce nutrients with greater assimilation etc. However, most GM cultures belonging to the second generation are similar in their properties to those of the first one and the only difference between them is that the former were produced with more sophisticated and developed techniques for plants genomes transformation; such techniques allow to avoid application of marker genes associated with resistance to antibiotics or regula- tory transcription elements (promoters and terminators). Besides, a considerable number of GM cultures belonging to the second generation are so called "hybridization stacks" (or GM stacks) obtained via conventional crossing of two or more GMO lines that are characterized with a combination of features inherent to parent GM lines. Therefore, this non-official classification to great extent deals with a period when GMO were created. In spite of being widely used, it is rather provisional and doesn't allow to unambiguously classify GM objects as per their specific properties.

Occurrence of GMO with combined features and a growth in their output worldwide (Table 1) made it necessary to create new approaches to safety assessment and state registration of such GMO in the Russian Federation (in 2015 corps of such GMO were grown on 58.5 million ha which accounted for $33 \%$ of all the areas where GM cultures were grown, and in 2016 it was 75.4 million ha or $41 \%$ of the overall areas with GM crops) $[1$, p. 94; 21, p. 34]. Analysis of the world experience accumulated in the sphere proves it is necessary to differentiate a set of examinations depending on a technique which was applied to obtain GMO with combined features; the first technique, or Transformation stack, means a new gene (or genes) is introduced into a genome of an already existing and previously registered GMO with a genetic engineering technique; the second one, or Molecular stack, means that a genome belonging to a donor plant is transformed by genetic engineering with a vector or multiple vectors that contain two or more genes responsible for new properties; the third one, or Breeding stack, means that two already existing GMO are used as two parents forms to obtain a hybrid with conventional selection. Lines which are obtained with transformation or molecular stack are considered to be new GMO and are subject to complete registration

\footnotetext{
${ }^{2}$ Surveillance over manufacturing and distribution of GMO-containing food products: A collection of methodical guidelines. Part 2 [web-source]. - M., 2008. -URL:http://files.stroyinf.ru/Data2/1/4293785/4293785688.htm (date of visit July 05, 2018).
} 
procedures [22, p. 1; 23, p. 2]. To regulate hybrid GMO application is the most difficult issue as it is impossible to identify such products as PCR-analysis results reveal two (and more) GMO lines in such a way as if there is a mixture of them. Lines obtained via hybridization are treated in different way in various jurisdictions; they are considered to be a conventional selection product in the USA, Canada, Australia, and New Zealand and are not subject to a state registration provided that the initial GM lines have already been registered [24, p. 45]; but each new GMO obtained with already registered parents GM lines should be registered again in the EU countries, however, as long as safety is concerned, registration only deals with possible effects produced by interaction between two proteins (genes) that provide occurrence of new properties.

It is should be taken into account, that when a GMO with combined features obtained via hybridization of three or more parent lines (GMO of higher order) is registered, it means that all possible combinations created due to genetic segregation of such GMO (splitting of features in F1 and higher generations according to Mendel law) should be considered automatically registered. For example, if we register a GMO obtained via hybridization of six parent lines, we should also register all 63 possible hybrids that belong to $\mathrm{F} 1$ generation and contain recombinant DNA. A similar approach is applied in the European Union, Argentina, Brazil, the Philippines, Paraguay, Uruguay, and Japan [25, p. 8; 26; 27].

Basing on the analysis of domestic and international experience, experts have developed requirements to assessing safety of GMO with combined features; these requirements should correspond to principles of control over GMO application as food products generalized in MG 2.3.2.3388-16 ${ }^{3}$. The requirements are very close to a system for GMO safety assessment existing in Russia, the only basic difference concerns only GMO with combined features obtained via hybridization: in case initial GM lines have already undergone state registration on the Customs Union territory, a simplified set of examinations can be applied. Safety assessment in such cases should include expert analysis and estimation of data submitted by an applicant as well as initial GM lines submitted/obtained at a registration stage; expert assessment of techniques for GMO detection, identification, and quantification; confirmation whether Parameters of GMO safety and quality (contents of toxic elements, mycotoxins, radionuclides, pesticides, etc.) conform to requirements fixed by the Customs Union Technical Regulations (TP TC 021/2011 "On food products safety" and/or corresponding Technical Regulations that fix obligatory requirements to specific food products) ${ }^{4}$. Experts should also analyze data on compositional equivalence of initial GM lines and their conventional analogues (macro- and micronutrients contents), results of toxicological, allergic and other research, as well as results of post-registration monitoring accomplished in countries where GMO with combined features have been registered earlier.

When developing approaches to assessing safety of GMO with combined features obtained via hybridization, experts were guided by two preconditions: first, advisability of requirements (they should be based on analysis of scientific literature, approaches to GMO safety assessment existing both in Russia and abroad, accumulated scientific base $[28$, p. $2-14 ; 29$, p. 1845-1849; 30, p. 71-73; 31, p. 104-107]); second, possibilities to make sure these requirements are met (since GMO obtained with hybridization can be identified only basing on inspection of documents as results of PCR analysis performed on such GMO reveal only occurrence of parent GM lines in a sample as if it contains a mixture of them, and a manufac-

\footnotetext{
${ }^{3}$ MG 2.3.2.3388-16. Medical and biological assessment of safety of vegetable GMO with combined features: Methodical guidelines [web-source] // KODEKS: an electronic fund of legal and reference documentation. - URL: http://docs.cntd.ru/document/456042958 (date of visit July 05, 2018).

${ }^{4}$ CU TR 021/2011. On food products safety: The Customs Union Technical Regulations [web-source] // KODEKS: an electronic fund of legal and reference documentation. - URL: http://docs.cntd.ru/document/902320560 (date of visit July 05, 2018).
} 
turer can always register separate lines and not a combined development). GM soya belonging to MON87701×MON89788 line is the only example of GMO with combined features that can be unambiguously determined with PCR technique; it is due to MON87701 line being commercially distributed only when it is combined with another line. Obviously, in a situation when there are the strictest requirements to confirming safety of GMO with combined features and with parent lines already been examined and registered on the Customs Union territory, most such GMO will remain beyond regulation. The suggested approach creates conditions that are utmost favorable for a manufacturer to enter legal frameworks and can provide a possibility to control GMO with combined features. Naturally, such approach can be applied only to
GMO with their parent lines being profoundly examined and allowed for use as food products.

To sum up, an issue of GMO regulation is a complicated one and it requires maximum possible interaction between controlling authorities and manufacturers, creation of an open and transparent system that will allow to meet requirements fixed in the Federal Law No.358-FZ issued on July $03,2016^{5}$ and an assignment by the RF President No. Pr-1178 issued on June 22, $2016^{6}$ on providing monitoring over impacts exerted by GMO people and the environment.

Funding. The work has been accomplished due to support by a grant provided by the Russian scientific fund No. 16-16-00124

Conflict of interests. The authors state there is no any conflict of interests.

\section{References}

1. Global Status of Commercialized Biotech/GM Crops: 2016. ISAAA Brief. No. 52. ISAAA: Ithaca, NY, 2016, 125 p. Available at: https://www.isaaa.org/resources/publications/briefs/52/download/isaaa-brief-52-2016.pdf (10.07.2017).

2. GM Approval Database. ISAAA Editorial Policy. Available at: http://www.isaaa.org/gmapprovaldatabase/ (10.07.2017).

3. Strategies for assessing the safety of foods produced by biotechnology. Report of a Joint FAO/WHO Consultation. Geneva, World Health Organization, 1991. Available at: http://apps.who.int/ iris/bitstream/handle/10665/41465/9241561459-eng.pdf?sequence=1\&isAllowed=y (10.07.2017).

4. Safety evaluation of foods derived by modern biotechnology: concepts and principles. Paris, Organization for Economic Co-operation and Development (OECD), 1993, 77 p. https://www.oecd.org/ science/biotrack/41036698.pdf (10.07.2017).

5. Application of the principles of substantial equivalence to the safety evaluation of foods or food components from plants derived by modern biotechnology. Report of a WHO Workshop. Geneva, World Health Organization, WHO/FNU/FOS/95.1. WHO, 1995. Available at: http://apps.who.int/iris/bitstream/10665/58909/1/WHO_FNU_FOS_95.1.pdf(10.07.2017).

6. Biotechnology and food safety. Report of a joint FAO/WHO consultation. Rome, FAO, 1996. Available at: http://www.fao.org/ag/agn/food/pdf/biotechnology.pdf (10.07.2017).

7. Mediko-biologicheskie issledovaniya uglevodorodnykh drozhzhei (1964-1970 gg.) [Biomedical studies of hydrocarbon yeast (1964-1970)]. In: A.A. Pokrovskoii ed. Moscow, Nauka Publ., 1972, 145 p. (in Russian).

8. Tyshko N.V., Selyaskin K.E., Tutel'yan V.A. Opredelenie naibolee chuvstvitel'nykh metodov dlya otsenki aktivnosti apoptoza $\mathrm{v}$ organakh krys na modeli toksicheskogo vozdeistviya tetrakhlormetana [Determination of the most sensitive methods for assessing the activity of apoptosis in rat organs on the model of toxic effects of carbon tetrachloride]. Mezhdunarodnyi zhurnal eksperimental'nogo obrazovaniya, 2015, no. 2-1, pp. 34-36 (in Russian).

\footnotetext{
${ }^{5}$ On making amendments into certain legal acts of the Russian Federation concerning improvement of state regulation in the sphere of genetic engineering: The Federal Law issued on July 03, 2016 No. 358-FZ [web-source] // KonsultantPlus. URL: http://www.consultant.ru/document/cons doc LAW 200732/ (date of visit October 01, 2018).

${ }^{6} \mathrm{~A}$ list of assignments as per results of "the Direct Line with Vladimir Putin": The assignment by the RF President sated June 22, 2016 No. Pr-1178. [web-source] // GARANT.RU. - URL: http://www.garant.ru/products/ipo/prime/doc/71874466/ (date of visit October 01, 2018).
} 
9. Tyshko N.V., Selyaskin K.E., Tutel'yan V.A. Detection of rat internal organs apoptosis activity based on model of ccl4 toxic effects. Fundamental'nye issledovaniya, 2014, no. 10 (pert 5), pp. 993-998 (in Russian).

10. Tyshko N.V., Selyaskin K.E., Tutel'yan V.A. Ispol'zovanie pokazatelei aktivnosti apoptoza v kachestve sistemnykh biomarkerov pri otsenke bezopasnosti GMO (stat'ya) [Using indicators of apoptosis activity as systemic biomarkers in assessing the safety of GMOs (article)]. Transgennye rasteniya: tekhnologii sozdaniya, biologicheskie svoistva, primenenie, biobezopasnost': Materialy V Vserossiiskogo simpoziuma. Moscow, 2014, pp. 192-195 (in Russian).

11. Tyshko N.V., Selyaskin K.E., Tutel'yan V.A. Pokazateli aktivnosti apoptoza v kachestve chuvstvitel'nykh biomarkerov pri otsenke bezopasnosti pishchevoi produktsii, poluchennoi $\mathrm{s}$ ispol'zovaniem sovremennykh biotekhnologii [Indicators of apoptosis activity as a sensitive biomarker in assessing the safety of food products obtained using modern biotechnology]. Sovremennye tekhnologii produktov pitaniya: Materialy mezhdunarodnoi nauchno-prakticheskoi konferentsii. Kursk, 2014, pp. 210-213 (in Russian).

12. Shestakova S.I., Zhminchenko V.M., Pashorina V.A., Sadykova E.O., Timonin A.N., Tyshko N.V. Izmenenie aktivnosti apoptoza $\mathrm{v}$ organakh krys linii Vistar na raznykh etapakh ontogeneticheskogo razvitiya [Changes in the activity of apoptosis in the organs of Wistar rats at different stages of ontogenetic development]. Voprosy pitaniya, 2015, vol. 84 (prilozhenie), no. 3, pp. 172-174 (in Russian).

13. Sadykova E.O., Tyshko N.V., Khismatullina Z.R. Ispol'zovanie pokazatelei apoptoza v kachestve biomarkerov vozdeistviya ekotoksikantov [Using apoptosis indicators as biomarkers of exposure to ecotoxicants]. Materialy shkoly molodykh uchenykh «Osnovy zdorovogo pitaniya i puti profilaktiki alimentarno-zavisimykh zabolevanii». Moscow, 2016, pp. 201-205 (in Russian).

14. Utembaeva N.T., Pashorina V.A., Selyaskin K.E., Tyshko N.V. Methodical approaches to studying influence of seasonal factor on rat reproductive function in experiments on alimentary influence. Voprosy pitaniya, 2009, vol. 78, no. 1, pp. 43-48 (in Russian).

15. Tyshko N.V., Zhminchenko V.M., Pashorina V.A., Saprykin V.P., Selyaskin K.E., Utembaeva N.T., Tutel'yan V.A. Assessment of the impact of GMO of plant origin on rat progeny development in 3 generations. Voprosy pitaniya, 2011, vol. 80, no. 1, pp. 14-28 (in Russian).

16. Zhminchenko V.M., Pashorina V.A., Selyaskin K.E., Tyshko N.V. Otsenka reproduktivnoi toksichnosti $\mathrm{V}$ mediko-biologicheskikh issledovaniyakh biotekhnologicheskoi produktsii: osobennosti postanovki eksperimenta [Assessment of reproductive toxicity in biomedical research of biotechnological products: features of the experiment]. Voprosy pitaniya, 2014, vol. 83, no. 3, pp. 258-259 (in Russian).

17. Tyshko N.V., Zhminchenko V.M., Selyaskin K.E., Pashorina V.A., Utembaeva N.T., Tutelyan V.A. Assessment of the impact of genetically modified LibertyLink ${ }^{\circledR}$ maize on reproductive function and progeny development of Wistar rats in three generations. Toxicology Reports, 2014, vol. 1, pp. 330-340. DOI: 10.1016/j.toxrep.2014.05.013

18. Tyshko N.V., Zhminchenko V.M., Pashorina V.A., Saprykin V.P., Selyaskin K.E., Utembaeva N.T., Tutel'yan V.A. Evaluation of the effect of genetically modified plants on rat progeny development. Gigiena $i$ sanitariya, 2011, no. 6, pp.73-77.

19. Tyshko N.V., Selyaskin K.E., Mel'nik E.A., Pashorina V.A., Zhminchenko V.M. The separate and combined effects of calcium pantothenate deficiency and cadmium intoxication on rat reproductive function. Voprosy pitaniya, 2012, vol. 81, no. 1, pp. 33-43 (in Russian).

20. Vasil I.K. The science and politics of plant biotechnology - a personal perspective. Nature biotechnology, 2003, vol. 21, no. 8, pp. 849-851.

21. Parisi C., Tillie P., Rodríguez-Cerezo E. The global pipeline of GM crops out to 2020. Nature Biotechnology, 2016, vol. 34, no. 1, pp. 31-36. DOI:10.1038/nbt.3449.

22. Guidance Document of the Scientific Panel on Genetically Modified Organisms for the risk assessment of genetically modified plants containing stacked transformation events. EFSA Journal, 2007, vol. 512, pp. $1-5$.

23. Commission Implementing Regulation (EU) No 503/2013 of 3 April 2013 on applications for authorisation of genetically modified food and feed in accordance with Regulation (EC) No 1829/2003 of the European Parliament and of the Council and amending Commission Regula- 
tions (EC) No 641/2004 and (EC) No 1981/2006. Available at: https://eur-lex.europa.eu/LexUriServ/LexUriServ.do?uri=OJ:L:2013:157:0001:0048:EN:PDF (10.07.2017).

24. Proposed Rule: Premarket Notice Concerning Bioengineered Foods. Federal Register, 66. US Food and Drug Administration. Washington, FDA, 2001, pp. 4706-4738.

25. Panel on Genetically Modified Organisms (GMO); Scientific Opinion on Guidance for risk assessment of food and feed from genetically modified plants. EFSA J. EFSA, 2011, vol. 2150, pp. 1-37.

26. European Food Safety Authority (EFSA). Available at: http://www.efsa.europa.eu/ (10.07.2017).

27. Organisation for Economic Co-operation and Development (OECD). Available at: http:// www.oecd.org/ (10.07.2017).

28. Kramer C., Brune P., McDonald J., Nesbitt M., Sauve A., Storck-Weyhermueller S. Evolution of risk assessment strategies for food and feed uses of stacked GM events. Plant Biotechnol. J., 2016, pp. 1-15. Available at: https://www.onlinelibrary.wiley.com/doi/full/10.1111/pbi.12551 (10.07.2017).

29. Weber N., Halpin C., Hannah L.C., Jez J.M., Kough J., Parrott W. Editor's choice: crop genome plasticity and its relevance to food and feed safety of genetically engineered breeding stacks. Plant Physiol, 2012, vol. 160, pp. 1842-1853.

30. De Schrijver A., Devos Y., Van den Bulckea M., Cadot P., De Loose M., Reheul D., Sneyers M. Risk assessment of GM stacked events obtained from crosses between GM events. Trends Food Sci. Technol., 2007, vol. 18, pp. 101-109. DOI:10.1111/pbi.12551

31. Kok E., Pedersen J., Onori R., Sowa S., Schauzu M., De Schrijver A., Teeri T. Plants with stacked genetically modified events: to assess or not to assess? Trends Biotechnol., 2014, vol. 32, pp. 70-73. DOI: 10.1016/j.tibtech.2013.12.001

Tyshko N.V., Sadykova E.O. Genetically modified food products: development of safety asseessment system in Russia. Health Risk Analysis, 2018, no. 4, pp. 119-126. DOI: 10.21668/health.risk/2018.4.14.eng

Received: 16.09 .2018

Accepted: 18.12 .2018

Published: 30.12 .2018 
UDC 663.813+658.562.64

DOI: $10.21668 /$ health.risk/2018.4.15.eng

Read

\title{
EXPERIENCE OF BUSINESS COMMUNITY ON HOW TO DETECT AND STOP MARKET DISTRIBUTION OF JUICES NOT CONFORMING TO LEGAL REQUIREMENTS
}

\author{
N.N. Ivanova, L.M. Khomich \\ "Russian Union of Juice Producers" (RSPS), a non-commercial organization, build 1, 3 Arkhangelsky Pereulok, \\ Moscow, 1101000, Russian Federation
}

Since 2010 The Russian Union of Juice Producers (RUJP) have been examining quality of juices that are sold on the Russian market. The basic goal here is to prevent manufacture and distribution of products that don't conform to legal requirements; to build up and maintain trust of consumers into juice products manufactured in the country; to create better conditions for fair competition. Since then, a control system has been built; is covers most juice manufacturers that work on the Russian market, procedures for research and results processing have been worked out and tested, and there is tight interaction between manufacturers, retailers and wholesalers, and state authorities responsible for control (surveillance). Quality monitoring system (QMS) is a structure created by the Russian Union of Juice Producers for accomplishing quality monitoring. QMS of the RUJP is similar to European systems for control over juices quality, such as EQCS (European Quality Control System for Juice and Nectars for Fruit and Vegetables), and SGF (Sure-Global-Fair). Annually the RUJP experts plan examinations (tests) of juices and decide on types of products that should be examined, a number of samples to be examined, and sampling criteria. Products to be examined are usually bought in retail outlets and they can be either manufactured by companies that are RUJP members or by side organizations. Products are purchased taking into account risk criteria worked out by the RUJP. There is an Expert Council that operates within the RUJP; its basic functions are to draw up examinations (tests) programs as per quality and safety criteria, assessment of marking and organoleptic properties of a product, as well as results of physical and chemical research. If any examination reveal a product that doesn't conform to legal requirements, the RUJP take action to stop its manufacturing and distribution on the market.

Key words: quality, juice, juice products, monitoring, risk criteria, quality control, system, examinations.

\section{Introduction.}

At present population in the RF consumes fruits and vegetables in quantities that are 25-30\% lower than recommended ${ }^{1}$ [1]. Juice products help to partially make up for the existing shortage of fruits and vegetables in people's nutrition. Up-to-date production technologies ensure correspondence of juices to natural structure of fruits and vegetables these juices are made of [2-5]; all the beneficial properties of fruits and vegetables are preserved in juices to the maximum possible extent [6]. And here some research reveals that certain nutrients are more biologically avail- able when they are consumed out of juices than out of fruits these juices are made of $[7,8]$. Overall, we can find more than 30 necessary nutrients and biologically active substances in juices [9-14].

Annually about 2.3 billion liters of juices products are consumed in Russia; they are juices, nectars, fruit drinks, and juice-containing drinks [15]. Most such products are manufactured by Russian enterprises; as per expert judgments, $97 \%$ share on the market belongs to Russian products. As juice manufacturing is highly developed in Russia, it becomes truly vital to provide good quality of

(C) Ivanova N.N., Khomich L.M., 2018

Natalya N. Ivanova - President (e-mail: rsps@rsps.ru; tel.: +7 (495) 628-99-19); ORCID: http://orcid.org/0000-00024604-7221).

Liudmila M. Khomich - Project Manager (e-mail: 1.homich@rsps.ru; tel.: +7 (495) 628-99-19; ORCID: http:// orcid.org/0000-0002-4312-3559).

${ }^{1}$ On Approval of recommendations on rational standards for food products consumption that correspond to the contemporary standards of healthy nutrition: The Order by the RF Public Healthcare Ministry No. 614 dated August 19, 2016 [Websource] // Kontur.Normative. - URL: https://normativ.kontur.ru/document?moduleId=1\&documentId=279426 (date of visit September 18, 2018). 
juice products, to make sure consumers have confidence in juice products, and to create favorable conditions for fair competition between manufacturers.

\section{European quality control systems for juice products.}

European self-regulating organizations have been performing control over juice products quality for several decades. There are both national and regional quality control systems for juice products. Some of them belong to EQCS (European Quality Control System for Juice and Nectars from Fruits and Vegetables that was established in 1994) ${ }^{2}$, some operate within SGF association (Sure-Global-Fair, established in 1986) ${ }^{3}$ either under EQCS control or beyond it. Nowadays about 30 European countries participate in this or that control system. All quality control systems are devoted to their common motto that goes as "Safety, Quality, and Fair Competition".

Self-control performed by participating manufacturers is a basic principle of all European quality control systems. It usually implements the most up-to-date techniques for laboratory research [16-19]. Manufacturers that participate in quality control systems operations widely apply voluntary audit on their enterprises. It helps to prevent distribution of poor quality products on the market. Additional quality control is accomplished via purchasing products in retail outlets and assessing their conformity with standards; such tests include also products manufactured by enterprises that are not covered by quality control systems. In case any products don't conform to fixed standards, their manufacturers are dealt with. In most cases issues are solved without any help from state controlling authorities.
Creation of a quality control system for juice products in Russia.

In 2002 several Russian manufactures who produced food products and were members of The Russian Union of Juice Producers (RUJP) signed "The 12th March 2002 Agreement". It was an attempt to create a nongovernmental self-regulating quality control system for juice products in Russia [16]. Juice products distributed on the Russian market were examined within this project but there was no further development and the project was terminated in 2007.

In 2010 the RUJP decided to return to such practices and initiated creation of a quality control system for juice products distributed on the RF territory. By that moment, all the necessary preconditions had occurred in Russia for creation of the Quality Monitoring System (QMS) that was aimed at detecting and eliminating distribution of products not conforming to legal requirements on the Russian market. The juice-producing branch was highly developed, there was a sufficient legal base, and competition on the marker was also great.

Overall development of the branch

On one hand, the branch is highly developed, both technically and technologically; on the other hand, products made by Russian manufacturers prevail on the market. It is also important that there is a solid basis for the system, namely the RUJP, an efficiently operating branch union that comprises manufacturers with $90 \%$ share of the overall juice products market.

Existing legal and regulatory base.

In 2008 the Federal Law No. 178-FL "The Technical Regulations for juice products made of fruits and vegetables" ${ }^{4}$ was issued;

\footnotetext{
${ }^{2}$ European Quality Control System for Juice and Nectars from Fruits and Vegetables [web-source]. - URL: http://www.eqcs.org/about-us/ (date of visit September 18, 2018).

${ }^{3}$ Sure-Global-Fair [web-source]. - URL: https://www.sgf.org/index.php?id=29\&L=1 (date of visit September 18, 2018).

${ }^{4}$ The Technical Regulations for juice products made of fruits and vegetables: The Federal Law issued on October от 27, 2008 No.178-FL [Web-source] //Garant. - URL: http://base.garant.ru/12163096/ (date of visit September 20, 2018).
} 
sufficient number of standards for research techniques has been developed. Therefore, there are certain "rules of the game" that are common for all the manufacturers. There are laboratories equipped with all the necessary devices and qualified experts who can perform measurements in the country. Besides there are experts with experience in the juice producing industry and particularly in inspecting juice products quality.

\section{Great competition on the market}

After 1998 economic crisis a lot of foreign companies left the Russian market thus stimulating domestic manufacturing. As per estimates given by package manufacturers, in 2000 approximately 100 companies produced juices in Russia. Juice market in the country was developing quite drastically in 2000s. Juice products outputs grew and in 2010 more than 3 billion liters of juice products were manufactured annually. The branch comprises both large manufacturers that specialize in juice products and a great number of smaller companies; new participants constantly appear on the market. As per the RUJP estimates, there are about 200 Russian enterprises that manufacture juice products.

The following tasks were to be solved within the Quality Monitoring System:

- to prevent manufacturing and market distribution of juice products that don't conform to legal requirements;

- to maintain public confidence in juice products;

- to create favorable conditions for fair competition. (QMS).

The RUJP Quality Monitoring System

The RUJP experts have created a control system that comprises most manufactures operating on the Russian market. They have developed and tested schemes for research performance and results processing; the organization interacts with manufacturers, state control (surveillance) authorities, and trade companies.

The System Council is a ruling body of the QMS and it is responsible for determining basic lines of the QMS activities and for making decisions as per research results. The Experts Council also operates within the QMS. Experts determine parameters for products research (examinations), assess marking and consumer package of products and inspect its organoleptic and physical-chemical properties in terms of their conformity with the requirements fixed in the Customs Union Technical Regulations. Qualified specialists who work in the juice manufacturing industry are among these experts.

The RUJP experts have worked out risk assessment criteria in order to efficiently determine products not conforming to legal requirements on the Russian market. They have outlined 17 risk criteria that can be conventionally divided into two groups, "manufacturer-related risks" and "product-related risks". "Manufacturer-related risks" are established on the basis of data on a manufacturer (a region, production volumes, types of package used in production, etc.) and (or) on the basis of research results obtained for products made by a manufacturer within the QMS. "Productrelated risks" are based on research data obtained for variable juice products (certain juice products that cause the highest risks, for example pomegranate juice) and (or) research results obtained for a specific product within the QMS. Each criterion is scored as per a scale (it can be from 1 to 5 scores or from 1 to 10 scores depending on a criterion). The criteria and their values are revised once a year taking into account new data obtained within monitoring activities.

\section{Activities related to quality monitoring within the QMS.}

Monitoring activities include the following basic stages: market research - examinations - results analysis - taking actions.

Marker research.

Since 2010 the RUJP have been keeping a register of juice products manufacturers that operate on the Russian market. This register contains data on manufacturers and their products. At present there are data on about 200 manufacturers and 2,700 various 
juice products in it. This register is used as a basis when products are selected for examinations.

\section{Examinations}

Examination programs are created by experts according to requirements fixed for juice products in the Customs Union Technical Regulations ${ }^{5}$. There are several types of such programs: basic, additional, and control ones. Basic programs are about examining samples of a specific juice product, for example, apple or orange juice. Additional programs can include examinations of products that are risky in terms of non-compliance, variable products as per a specific parameter, products in specific package, etc. Control programs are designed for products that previously were determined as non-compliant as per results of basic or additional examination programs. Control examinations are performed once a year with their basic purpose being to check whether corrections declared by manufacturers have been truly efficient and non-compliance has been eliminated.

Products samples for examinations are purchased in retail outlets all around the country, and products manufactured by enterprises that are the RUJP members and by those that are not are purchased equally. Purchased samples are given to certified test laboratories where they are examined as per physical and chemical parameters fixed by experts in the field. The RUJP cooperates with more than 10 laboratories (both domestic and foreign ones), and each sample is examined on average as per $20-25$ parameters.

Results analysis.

Results obtained via chemical and physical examinations are then submitted to the
QMS Experts Council. Experts also assess products marking and their organoleptic properties. A report on products compliance with the legal requirements is made on the basis of complex analysis. According to these requirements, juice products are to be made of fresh fruits and vegetables or fruits and vegetables that are preserved fresh via physical effort on their edible parts and should preserve all the properties of fruit or a vegetable they are made of ${ }^{5}$. And here each juice should preserve its unique nutrient profile [9-13]. Experts who perform examinations are to have profound knowledge on natural composure of fruits, vegetables, and juices made of them, as well as great experience in juice products identification.

\section{Taking actions.}

Results obtained in performed examinations and inspections results on products are sent to their manufacturers; the same results obtained for products manufactured as per orders from retail networks are sent to these networks. When non-compliance is detected, results are also sent to state control (surveillance) authorities in order to attract their attention to non-compliant products distributed on the market. The RUJP experts provide consultations in all cases when certain correcting actions are required for eliminating detected noncompliances [20, 21].

The results of QMS operations over 2010-2017.

Over 2010-2017 33 examination programs were accomplished within the QMS operations, 23 basic and 10 additional and control ones. Experts examined about 1,200 products samples manufactured by more than 150 manufacturers. Overall, assessment of research re-

${ }^{5}$ CU TR 021/2011. On food products safety: The Customs Union Technical Regulations [Web-source] // KODEKS: an electronic fund of legal and reference documentation. - URL: http://docs.cntd.ru/document/902320560 (date of visit September 20, 2018).

CU TR 022/2011. Food products as regards their marking: The Customs Union Technical Regulations [Websource] // KODEKS: an electronic fund of legal and reference documentation. - URL: http://docs.cntd.ru/document/902320347 (date of visit September 20, 2018).

CU TR 023/2011. TR for juice products made of fruits and vegetables: The Customs Union Technical Regulations [Web-source] // KODEKS: an electronic fund of legal and reference documentation. - URL: http:// docs.cntd.ru/document/902320562 (date of visit September 20, 2018). 
sults on juice products market reveals that about $95 \%$ juice products on the Russian market conform to legal requirements. Analysis of data obtained via control examinations shows that in $60 \%$ cases non-compliant products that have been detected due to monitoring are either brought to conformity or their production stops.

Results of the QMS activities have proven its efficiency as an instrument of non-governmental control aimed at improvement of juice products quality on the market; they also indicate it is necessary to further develop the RUJP activities in the sphere.

Funding. The research was not granted any sponsor support.

Conflict of interests. The authors state there is no any conflict of interests.

\section{References}

1. Potreblenie produktov pitaniya $\mathrm{v}$ domashnikh khozyaistvakh [Household food consumption]. Federal'naya sluzhba gosudarstvennoi statistiki: ofitsial'nyi sait. Available at: http://www.gks.ru/wps/ wcm/connect/rosstat_main/rosstat/ru/statistics/publications/catalog/doc_1140095125312

$(18.10 .2018)$ (in Russian).

2. Landon S. Fruit juice nutrition and health. Food Australia, 2007, vol. 59, pp. 533-538.

3. Nicklas T.A., O’Neil C., Fulgoni V. Replacing $100 \%$ Fruit Juice with Whole Fruit Results in a Trade Off of Nutrients in the Diets of Children. Current Nutrition and Food Science, 2015, vol. 11, no. 4, pp. 267-273.

4. Nicklas T.A., O’Neil C., Fulgoni V. Consumption of $100 \%$ Fruit Juice is Associated with Better Nutrient Intake and Diet Quality but not with Weight Status in Children: NHANES 2007-2010. Int. J. Child. Health Nutri., 2015, vol. 4, pp. 112-121.

5. Nicklas T.A., O'Neil C.E., Kleinman R. Association between $100 \%$ juice consumption and nutrient intake and weight of children aged 2 to 11 years. Arch. Pediatr. Adolesc. Med., 2008, vol. 162, pp. 557-565.

6. Clemens R., Drewnowski A., Ferruzzi M., Toner C.D., Welland D. Squeezing Fact from Fiction about 100 \% Fruit Juice: Workshop Proceedings. Adv. Nutri., 2015, vol. 6, no. 6-2, pp. 236s-241s.

7. Aschoff J.K., Rolke C.L., Breusing N., Bosy-Westphal A., Högel J., Carle R., Schweiggert R.M. Bioavailability of $\beta$-cryptoxanthin is greater from pasteurized orange juice than from fresh oranges - a randomized cross-over study. Mol. Nutr. Food Res., 2015, vol. 59, pp. 1896-1904.

8. Aschoff J.K., Riedl K.M., Cooperstone J.L., Hogel J., Bosy-Westphal A., Schwartz S.J., Carle R., Schweiggert R.M. Urinary excretion of Citrus flavanones and their major catabolites after consumption of fresh oranges and pasteurized orange juice - a randomized cross-over study. Mol. Nutr. Food Res., 2016, vol. 60, pp. 2602-2610.

9. Ivanova N.N., Khomich L.M., Perova I.B. Nutrientnyi profil' yablochnogo soka [Apple Juice Nutrient Profile]. Voprosy pitaniya, 2017, vol. 86, no. 4, pp. 125-136 (in Russian).

10. Ivanova N.N., Khomich L.M., Perova I.B. Orange juice nutritional profile. Voprosy pitaniya, 2017, vol. 86, no. 6, pp. 103-113 (in Russian).

11. Ivanova N.N., Khomich L.M., Beketova N.A. Tomato juice nutritional profile. Voprosy pitaniya, 2018, vol. 87, no. 2, pp. 53-64 (in Russian).

12. Ivanova N.N., Khomich L.M., Perova I.B., Eller K.I. Sour cherry juice nutritional profile. Voprosy pitaniya, 2018, vol. 87, no. 4, pp. 78-86 (in Russian).

13. Ivanova N.N., Khomich L.M., Perova I.B., Eller K.I. Nutrientnyi profil' greipfrutovogo soka [Grapefruit Juice Nutrient Profile]. Voprosy pitaniya, 2018, vol. 87, no. 5, pp. 85-94 (in Russian).

14. Souci S.W., Fachmann W., Kraut H. Food composition and nutrition tables, based on the 7th edition. Stuttgart, Medpharm GmbH Scientific Publishers, 2008, pp. 1198-1199.

15. RSPS podvodit itogi raboty za 2017 god / Novosti [RSEF summarizes the work for 2017 / News]. Rossiiskii soyuz proizvoditelei sokov (RSPS). Available at: http://www.rsps.ru/news (18.09.2018) (in Russian) (18.09.2018). 
16. Cozzolino D. Recent trends on the use of infrared spectroscopy to trace and authenticate natural and agricultural food products. Applied Spectroscopy Reviews, 2012, vol. 47, no. 7, pp. 518-530.

17. Benjamin S.R., de Oliveira Neto J.R., de Macedo I.Y.L., Bara M.T.F., Gunha L.C., de Faria Carvalho L.A., de Souza Gil E. Electroanalysis for Quality Control of Acerola (Malpighia emarginata) Fruits and their Commercial Products. Food Analytical Methods, 2015, vol. 8, no. 1, pp. 86-92.

18. Hosu A., Cimpoiu C. Thin-layer chromatography applied in quality assessment of beverages derived from fruits. Journal of Liquid Chromatography and Related Technologies, 2017, vol. 40, no. 5-6, pp. 239-246.

19. Nakonieczna A., Paszkowski B., Wilczek A., Szypłowska A., Skierucha W. Electrical impedance measurements for detecting artificial chemical additives in liquid food products. Food Control, 2016, vol. 66, pp. 116-129.

20. Vinogradova I.V. Metodicheskie rekomendatsii po samoregulirovaniyu kachestva produktsii. In-t nats. proekta "Obshchestv, dogovor" [Guidelines for self-regulation of product quality. Inst Nat project "Societies contract"]. Moscow, MakTsentr Publ., 2003, 73 p. (in Russian).

21. Chudakova E.A., Kashirina N.A. Vysokoe kachestvo i bezopasnost' sokovoi produktsii kak rezul'tat primeneniya strukturirovannoi sistemy menedzhmenta na predpriyatiyakh pishchevoi promyshlennosti [High quality and safety of juice products as a result of the use of a structured management system at food industry enterprises]. Tekhnologii i tovarovedenie sel'skokhozyaistvennoi produktsii, 2014, no. 3, pp. 66-75 (in Russian).

Ivanova N.N., Khomich L.M. Experience of business community on how to detect and stop market distribution of juices not conforming to legal requirements. Health Risk Analysis, 2018, no. 4, pp. 127-132. DOI: 10.21668/health.risk/2018.4.15.eng

Received: 16.10 .2018

Accepted: 14.12 .2018

Published: 30.12.2018 


\section{SCIENTIFIC REVIEWS}

UDC 544.73: 613.2

DOI: $10.21668 /$ health.risk/2018.4.16.eng

\section{NANOMATERIALS IN FOOD PRODUCTS AND THEIR PACKAGE: COMPARATIVE ANALYSIS OF RISKS AND ADVANTAGES}

\section{I.V. Gmoshinski, V.A. Shipelin, S.A. Khotimchenko}

Federal Research Center for Nutrition, Biotechnology and Food Safety, 2/14 Ust'inskiy proezd, Moscow, 109240, Russian Federation

Nanomaterials (NMs) are applied in many spheres related to food products manufacturing including nanodispersed forms of food substances, nano-encapsulates, and nano-micelles, food additives with improved functional characteristics, new packaging materials with enhanced gas-, photobarrier, and antimicrobic properties. High chemical and catalytic activity of nanoparticles (NPS) and their ability to penetrate through biological barriers and accumulate in a body makes a lot of NMs toxic, and their toxic properties are to be taken into account when assessing safety of the abovementioned products. There are some priority NMs from the point of view of risk assessment and prospective hygienic standardization; they are silver NPs, NPs of amorphous silicon dioxide (aerosil), titanium dioxide NPs, and carbon nanotubes. Results of toxicological-hygienic research performed on laboratory animals revealed that a probable allowable daily dose of silicon dioxide (SiO2) NPs consumed with food should not exceed $1 \mathrm{mg} / \mathrm{kg}$ of body weight. And as nanosized $\mathrm{SiO} 2$ is used as a food additive, an issue of its hygienic standardization and regulation is truly vital. Silver NPs exert various toxic effects that have been examined in vivo; these effects are based on their ability to promote a dozed release of cytotoxic ions of silver (Ag+) in target organs (first of all, in the liver) under exposure to endogenous oxidants. Signs of silver NPs toxicity become obvious starting from a dose equal to $1 \mathrm{mg} / \mathrm{kg}$ of body weight and a maximum noobserved-adverse-effect-level (NOAEL) can be estimated as $0.1 \mathrm{mg} / \mathrm{kg}$. If values are recalculated for a human body taking into account adjusting coefficients, a non-hazardous dose of silver NPs under oral exposure amounts to $70 \mu \mathrm{g}$ a day. This estimation coincides with the upper permissible level that is fixed in Russia for consumption of silver as a chemical element. Titanium dioxide NPs and carbon nanotubes considered as possible food contaminants in the long term cause population health risks that require profound toxicological-hygienic assessment.

Key words: nanoparticles, silicon dioxide, titanium dioxide, carbon nanotubes, food additives, package, risk assessment.

\section{Introduction}

Artificial nanomaterials (NM) are applied in food products manufacturing in several spheres; they are nanodisperse forms of food substances with higher biological availability, digestibility, and compatibility with other components of food products; nanoencapsulates and nano-micelles that allow to obtain water-soluble form of lipophilic nutrients; food additives including those with im- proved functional properties; new packaging materials with better gas-, photo-barrier, and antimicrobic features. As per forecasts made in the beginning of the 21 st century, experts expected hundreds of food products, food additives and ingredients, and packaging materials manufactured with application of nanoparticles (NPs) and NM to appear on the market. However, there are certain problems related to practical implementation of innova-

(C) Gmoshinski I.V., Shipelin V.A., Khotimchenko S.A., 2018

Ivan V. Gmoshinski - Doctor of Biological Sciences, Leading Researcher at Laboratory for Food Toxicology and Nanotechnologies Safety Assessment (e-mail: gmosh@ion.ru; tel.: +7 (495) 698-53-71; ORCID: https://orcid.org/0000-00023671-6508, SPIN-код: 4501-9387).

Vladimir A. Shipelin - Candidate of Medical Sciences, Senior Researcher at Laboratory for Food Toxicology and Nanotechnologies Safety Assessment (e-mail: v.shipelin@yandex.ru; tel.: +7 (495) 698-53-71; ORCID: https://orcid.org/00000002-0015-8735, SPIN-код: 6779-8351).

Sergei A. Khotimchenko - Doctor of Medical Sciences, Professior, Head at Laboratory for Food Toxicology and Nanotechnologies Safety Assessmen (e-mail: hotimchenko@ion.ru; tel.: +7 (495) 698-52-35); ORCID: https://orcid.org/00000002-5340-9649, SPIN-код: 9310-3018). 
tive technologies, such as nanotechnological products being more expensive than conventional ones, absence of sufficient regulatory base, and public concern with possible risks associated with effects produced by NP and nano-objects on people and the environment. All the above mentioned resulted in nanotechnologies being applied in food manufacturing in much smaller volumes than it was expected $[1,2]$. Our short review focuses on basic risks related to application of nanomaterials in food products.

\section{Regulatory base for nano-safety}

NMs possess high chemical and catalytic activity and they are able to penetrate through biological barriers and accumulate in a body; these properties make many NMs toxic, and it should be taken into account when assessing possible risks associated with their effects on a body. Volumes of NMs production and their insolubility in water and biological media are considered to be their basic risks criteria in the EU countries, the USA, etc. In Russia a system of control over NMs safety was created; the system includes about 50 various regulatory and methodological documents approved by Rospotrebnadzor. Apart from the above-mentioned factors, it considers and takes into account such NM-related risk factors as their well-proven biological activity and toxicity, ability to penetrate a body and accumulate in organs and systems, migrate together with environmental objects, and exert certain influence on ecological systems [1, 3].

According to the CU TR $021 / 2011^{1}$ NM-containing food products or products manufactured with nanotechnologies and therefore having certain properties that make them principally different from products manufactured with "conventional" technologies are to be considered "innovative products" (new ty- pe products), and it is obligatory to assess their conformity through state certification. At present, there are about 60 nanoindustry products that have been certified in the RF and the Customs Union countries as innovative food products. Basically, they are biologically active additives (BAA) that contain nano-sized food substances; complex food additives such as emulsifiers, and certain technological aids and composite packaging materials that contain nano-clays. Besides, elements of nanotechnologies are widely used in membrane processing (nano- and ultra-filtration) of milk, lactoserum, juices, drinking water, etc. However, food products obtained with such technologies are conventional as per their structure and properties.

We analyzed a range of food products distributed on the market together with regulatory documents that fix requirements to their structure and safety; our analysis revealed that volumes of NPs and NMs application in food manufacturing were probably underestimated. Here we primarily mean that there are certain food additives that can contain nano-substances but sizes of their particles are not controlled or regulated by either Russian or foreign regulatory documents. Among them, there are such most interesting permissible food additives as amorphous silicon dioxide and titanium dioxide. Application of colloid metallic silver with particles smaller than $100 \mathrm{~nm}$ and multi-wall carbon nanotubes (MW CNTs) in food products is also of great interest if it comes to probable health risks.

\section{Amorphous silicon dioxide}

Amorphous silicon dioxide $\left(\mathrm{SiO}_{2}\right)$, or E551, is applied as a substance that prevents food products from caking and as a carrier. CU TR $029 / 2012^{2}$ fixes its permissible concentrations in spices (not more than $30 \mathrm{~g} / \mathrm{kg}$ ), food

\footnotetext{
${ }^{1}$ CU TR 021/2011. On food products safety: The Customs Union Technical Regulations [web-source] // KODEKS: an electronic fund of legal and reference documentation. - URL: http://docs.cntd.ru/document/902320560 (date of visit January 16, 2017).

${ }^{2}$ CU TR 029/2012. Requirements to safety of food additives, flavoring agents, and technological aids (last supplemented on September 18, 2014) [web-source] // KODEKS: an electronic fund of legal and reference documentation. - URL: http://docs.cntd.ru/document/902359401 (date of visit January 16, 2017).
} 
products that are tightly wrapped in foil $(30 \mathrm{~g} / \mathrm{kg})$, icing sugar $(10 \mathrm{~g} / \mathrm{kg})$, salt and its substitutes $(10 \mathrm{~g} / \mathrm{kg})$, cheese and cheese products $(10 \mathrm{~g} / \mathrm{kg})$, flavoring agents $(50 \mathrm{~g} / \mathrm{kg})$. Food raw materials that contain E551 are allowed for use in manufacturing children's nutrition. E551 content is not regulated in pelleted food products, biologically active additives (BAA), and sugary confectionary (except chocolate). Apart from above mentioned food products, amorphous $\mathrm{SiO}_{2}$ can possibly enter a body with medications and cosmetics (toothpastes etc.).

Fine-dispersed pyrogenic E551 (aerosil) accounts for a considerable part of the overall volumes of applied E551; specific surface area of aerosil is equal to $300-380 \mathrm{~m}^{2} / \mathrm{g}$, that is, according to a simplest geometric calculation, it consists of nanoparticles (NPs). Experts analyzed the structure of this E551 form with transmission electron microscopy (TEM) and atomic force microscopy, dynamic light scattering and spectrum acoustics; the analysis revealed that this material on its ultrastructural level was made of weakly bound (agglomerated) spherical NPs sized 20-60 nm [4]. At the same time, JECFA specification for this food additive [5] doesn't contain any information on a size of its particles, and this size, as a rule, is not controlled and declared by food products manufactures; consequently, a considerable part of food products distributed on the market can contain this substance in its nano-form. As per data given in [6], at present food exposure of a man to $\mathrm{SiO}_{2} \mathrm{NPs}$ can exceed $1.8 \mathrm{mg} / \mathrm{kg}$ of body weight per day.

Experimental research performed on laboratory animals revealed that $\mathrm{SiO}_{2} \mathrm{NPs}$ were biologically accessible under introduction into the gastrointestinal tract [6]. A subacute 92-day experiment performed on rats showed that when nano-sized $\mathrm{SiO}_{2}$ of "Aerosil" type was introduced in a dose equal to $100 \mathrm{mg} / \mathrm{kg}$ of body weight, animals had leucopenia, a share of T-helpers decreased, and a share of cytotoxic lymphocytes grew up, immune-regulatory index (CD4/CD8) also went down, and an imbal- ance occurred between pro- and anti-inflammatory cytokines, such as TNF- $\square$ and IL-10; all the above mentioned changes indicated there was an adverse effect on the immune system [7]. Morphologic examination revealed that the mucous tunic of the small intestine was the primary target organ for $\mathrm{SiO}_{2}$ NPs introduced with food; experts observed there a massive lymph-macrophage and eosinophilic infiltration of villi that was a sign of a stronger local immune reaction [8]. Taking into account 2 tenfold assurance factors when transferring data obtained in in vivo model onto a human body, we still understand that the possible allowable daily dose of $\mathrm{SiO}_{2}$ NPs introduced with food shouldn't exceed $1 \mathrm{mg} / \mathrm{kg}$ of body weight, and it calls for obligatory hygienic standardization and regulation of nano-sized $\mathrm{SiO}_{2}$, used as a food additive.

\section{Nano-sized titanium dioxide}

Titanium dioxide $\mathrm{TiO}_{2}$ is applied in food industry as a white dye E171 in fish, dairy, and confectionary products as well as in BAA shells and capsules. This substance can also be found in cosmetics sunscreens, varnishand-paint products, pharmaceuticals, and photocatalytic neutralizers - air purifiers. JECFA specification for this food additive [9] doesn't contain any information on sizes of its particles. Commercial $\mathrm{TiO}_{2}$ products that are distributed on the market are two crystalloid modifications, rutile and anatase [10]. The latter is highly likely to contain NPs. Given all that, we can state that $\mathrm{TiO}_{2}$ NPs can most probably be introduced into a body, notably with food or BAA [11].

Experts performed an experiment on animals that involved inhalation exposure to $\mathrm{TiO}_{2}$ NPs and this exposure led to emphysema-like damage to the lung tissues [12]. When $\mathrm{TiO}_{2}$ NPs in a dose equal to $1 \mathrm{mg} / \mathrm{kg}$ of body weight or more were introduced into laboratory animals orally during a sub-acute experiment, experts revealed disorders in functioning of energy and amino-acid metabolism enzymes [13], P 450 cytochrome system [14], immune system [15, 16], and 
liver proteome [17]. When these NPs enter the intestines, they can damage entherocytes and become biologically accessible to a certain extent $[18,19]$. Maximum NOAEL (noobserved-adverse-effect level) of $\mathrm{TiO}_{2} \mathrm{NPs}$ for rats in anatase and rutile forms amounts to less than $1 \mathrm{mg} / \mathrm{kg}$ of body weight during a 30-day experiment. And here it is impossible to precisely assess exposure of a man to these NPs, as we don't have any idea on what part of E171 food additive is a nano-material. Available data on oral toxicity of nano-sized $\mathrm{TiO}_{2}$, as opposed to its traditional form ("titanium white" with micron-sized particles [10]), allowed French Agency for Food, Environmental and Occupational Health \& Safety (ANSES) to make a proposal in 2017 to reconsider nano-sized E171 safety for people [20].

\section{Nano-sized colloid silver}

By 2016, 20 various biologically active additives that contain metallic silver NPs have been registered in the RF; this active component in BAA is a source of silver microelement. Besides, silver NPs can migrate into food products from packaging materials with anti-microbe properties. Valid legislation forbids to apply silver NPs in food manufacturing as disinfectants (preservatives or technological aids). However, as there are a lot of developments in the sphere, we can assume that such products can be registered and occur on the market some time in future. Silver NPs are the most widely used NM in production of perfume and cosmetics, varnish-and-paint, and disinfectants (by 2016 more than 130 products of the kind have been registered in the RF), and it makes involuntary contamination of food products with these NPs quite possible. As per data taken from literature, in 2011 the overall silver NPs production in the world amounted to more than 500 tons in terms of Ag, but in 2015 it could well exceed 1,000 tons and it corresponds to about $140 \mathrm{mg} / \mathrm{kg}$ per each person in the world.

As per data obtained via TEM, sizes of silver NPs are, as a rule, from $8-10$ to $60-80 \mathrm{~nm}$; these particles are round-shaped, sometimes they can have triangle or polyhedral shape, their contours are sharp, and their electron density is high. Industries produce several types of silver NPs. First of all, there is so called "ions-free silver" obtained via laser ablation or via electric explosion of a metal target. Secondly, they produce "cluster" silver that is synthesized through a photocatalytic procedure with polyvinylpyrrolidone (food additive E1201); and finally, there is colloid silver obtained via chemical reduction (under exposure to aldehydes) and stabilized with citric acid anion (E330) and colloid silver obtained via so called "biochemical synthesis" when silver salt is reduced with quercetin and sodium dioctyl sulfosuccinate (E480).

Silver NPs that are introduced into the gastrointestinal tract with food and water can be absorbed in it (biological accessibility amounts to about $1-3 \%$ as per data of radioisotopic research) [21, 22]. Absorbed NPs are distributed in organs and systems and their maximum quantity is accumulated in the liver and spleen; small quantities of NPs can penetrate through the blood-brain barrier in the brain and persist there for a long time [23]. Research performed with radioisotope markers revealed that small quantities of silver NPs (less than $1 \%$ of a consumed dose) can penetrate through the fetoplacental barrier of pregnant rats and accumulate in fetuses as well as be excreted with breast milk [24].

As per data obtained in multiple experiments that are described in literature, silver NPs produce toxic effects on eukaryote cells in a culture, water and soil organisms, and laboratory animals under inhalation, epicutaneous, and oral exposure.

Experts give rather controversial data on toxic impacts exerted by silver NPs under multiple oral introduction into laboratory animals. Thus, the following research [23] didn't reveal any signs of silver NPs toxicity for rats in a dose equal to $90 \mathrm{mg} / \mathrm{kg}$ of body weight. On the other hand, when silver NPs were introduced in a dose that exceeded $125 \mathrm{mg} / \mathrm{kg}$ of body weight, they produced toxic effects on rats' liver [25]. When mice were exposed to silver NPs in doses higher 
than $1 \mathrm{mg} / \mathrm{kg}$ of body weight, histopathologic changes occurred in their liver and kidneys [26]. Some adverse shifts in integral and biochemical parameters were detected in rats that were exposed to silver NPs in doses equal to $1 \mathrm{mg} / \mathrm{kg}$ of body weight and doses were introduced daily during a month [27]. As per data taken from [28], a threshold dose of silver NPs that produced adverse effects on mice amounted to less than $0.01 \mathrm{mg} / \mathrm{kg}$.

Scientific Research Institute of Nutrition and Rospotrebnadzor's Federal Scientific Center for Medical and Preventive Health Risk Management Technologies performed joint research to examine silver NPs that were the most widely spread in Russia and had the greatest practical significance, namely silver stabilized with polyvinylpyrrolidone. The substance was examined via modeling its intragastric introduction into the gastrointestinal tract of rats and mice in doses ranging from 0.1 to $10 \mathrm{mg} / \mathrm{kg}$ of body weight recalculated per silver; the experiments were subacute and lasted for 90-92 days. Various dose-dependent effects on behavioral reactions were revealed in male $\mathrm{BALB} / \mathrm{c}$ mice with Open field Animal test; these effects included a decrease in frequency of actions that required physical efforts and shorter periods of time spent on such actions; greater anxiety as per parameters of frequency and duration of orientation and exploration activities and grooming. Morphological research revealed changes in liver and spleen tissues, and, to a smaller extent, heart and kidneys tissues; a range of these changes and their intensity grew together with an increase in NMs doses [29]. A similar experiment performed on male Wistar rats allowed to reveal adverse shifts under exposure to a NM dose equal to $10 \mathrm{mg} / \mathrm{kg}$ of body weight recalculated per Ag as per parameters of body weight growth, relative lungs weight, average volume of an erythrocyte, hemoglobin concentration in erythrocytes, and relative fraction of neutrophils and lymphocytes. When NM doses were within $1-10 \mathrm{mg} / \mathrm{kg}$ of body weight, the fol- lowing effects were detected in rats' liver: there was an increase in activity of key enzymes of the 1st and 2nd stages in xenobiotics detoxification system, a decrease in activity of common arylsulphatase A and B, and $\beta$-galactosidase (but there were no changes in their non-sedimentary activity). Lower uric acid concentration and more active alkaline phosphatase were detected in blood plasma. Sub-acute introduction of silver NPs didn't lead to any significant changes in normal microbiota structure, but still it inhibited growth of certain transitory components, including opportunistic microorganisms [30]. Experts analyzed microelement status of rats that were exposed to silver NPs and revealed dose-dependent accumulation of $\mathrm{Ag}$ in the liver, kidneys, and spleen and it was accompanied with an authentic decrease in $\mathrm{Cu}$ concentration in the liver, a decrease in $\mathrm{Zn}$ and Co concentration and an increase in Mn concentration in the liver, an increase in $\mathrm{Cd}, \mathrm{Cr}$ and Ni concentration in the spleen. Parameters showing proper provision with Se (excretion with urine, concentration in blood plasma, and activity of glutathione peroxidase erythrocytes) were authentically lower in rats that received silver NPs in doses equal to $1-10 \mathrm{mg} / \mathrm{kg}$ of body weight and it proves there is antagonism between Ag (contained in NPs) and Se [31]. Morphological changes in rats' liver, spleen and kidneys became more apparent as NM doses grew. And also there was an edema in the liver, eosinophilic and lymph-macrophage infiltration in the hepatoportal tracts, middle-sized and large fatty vacuoles in hepatocytes cytoplasm. A threshold NM dose that induced such changes amounted to not more than $1.0 \mathrm{mg} / \mathrm{kg}$ of body weight [32].

Obtained experimental data are well in line with a hypothesis about a basic mechanism of toxic effects produced by silver NPs in vivo: these particles are assumed to induce a dosed release of cytotoxic silver ions $\left(\mathrm{Ag}^{+}\right)$ under exposure to endogenous oxidizers (superoxide-anion, peroxides, peroxynitrite, hypochlorite-ion and others) produced by 
mononuclear cells in relevant target organs (first of all, the liver). And here an asserted effect produced by silver NPs on microbiota components in the recovery medium of the large intestine contents turns out to be rather insignificant.

Obtained data allowed to come to a conclusion that significant signs of silver NPs toxicity become obvious starting from a dose equal to $1 \mathrm{mg} / \mathrm{kg}$ of body weight introduced orally, and a maximum no-observed-adverseeffect level (NOAEL) can be estimated as being equal to $0.1 \mathrm{mg} / \mathrm{kg}$ of body weight. When we recalculate this dose for a human body and take into account two tenfold assurance factors, we realize that a safe NPs dose recalculated per silver should amount to $0.001 \mathrm{mg} / \mathrm{kg}$ that corresponds to $70 \mu \mathrm{g}$ of silver per day for a man with body weight equal to $70 \mathrm{~kg}$. We should note that this estimation coincides with the upper permissible level of consumption for silver as a chemical element that is now accepted in the RF.

\section{Carbone nanotubes}

Carbone nanotubes (CNTs) have some unique physical and chemical properties and are now being widely used in composite construction materials, ion current sources, microelectronics, and other products. There are proposals on CNTs application as plant growth stimulators [33], agrochemicals carriers [34], agents for controlling rodents-depredators [35], and components of packaging for food products [36]. Data on oral toxicity of both one-wall CNTs and multi-wall ones are fragmentary. There is some evidence that they exert adverse influence on male reproductive sphere [35], and induce an increase in hepatic enzymes levels, antioxidant stress, and unfavorable changes in lipoproteins levels [37]. A lot of effects produced by CNTs in subacute experiments are more obvious under exposure to extremely low doses (less than $0.1 \mathrm{mg} / \mathrm{kg}$ of body weight) than high ones $(50 \mathrm{mg} / \mathrm{kg}$ of body weight and higher). Obtained data indicate that food contamination with CNTs is a probable health risk factor that requires more profound toxicological and hygienic assessment.

\section{Conclusion}

All the reviewed data on probable health risks caused by NPs and NMs occurrence in food products allow us to formulate the following recommendations: 1) it is advisable to include statements on obligatory declaring of particles size for food additives into valid regulatory documents that allow application of nano-substances; it is also advisable to make specific marking on food products that contain artificial NPs and NMs; it is necessary to work out hygienic standards for concentrations of priority NMs (silicon and titanium dioxide, CNTs, and colloid silver) in consumer products as well as interstate standards on procedures for controlling contents of artificial nanocomponents in food products

Gratitude. The work has been accomplished due to a grant given for fulfilling a state task within the Fundamental Scientific Research Program (The RF Federal Agency for Scientific Organizations, Subject No. 0529-2014-0045).

The authors state there is no any conflict of interests.

\section{References}

1. Onishchenko G.G., Tutel'yan V.A., Gmoshinskiy I.V., Khotimchenko S.A. Development of the system for nanomaterials and nanotechnology safety in Russian Federation. Gigiena i sanitariya, 2013, no. 1, pp. 4-11 (in Russian).

2. Peters R.J.B., Bouwmeester H., Gottardo S., Amenta V., Arena M., Brandhoff P. [et al.]. Nanomaterials for products and application in agriculture, feed and food. Trends Food Sci. Technol, 2016, vol. 54, pp. $155-164$.

3. Tutel'yan V.A., Khotimchenko S.A., Gmoshinskiy I.V., Tyshko N.V., Gapparov M.M., Baturin A.K. [et al.]. Sovremennaya zakonodatel'naya, normativnaya i metodicheskaya baza v oblasti obespecheniya bezopasnosti pishchevoy produktsii v Rossiyskoy Federatsii [Modern legislative, regulatory and methodological 
framework in the field of food safety in the Russian Federation.]. Sovet Federatsii Federal'nogo sobraniya Rossiyskoy Federatsii. Analiticheskiy vestnik, 2013, vol. 500, no. 16, pp. 33-46 (in Russian).

4. Shumakova A.A., Arianova E.A., Shipelin V.A., Sidorova Yu.S., Selifanov A.V., Trushina E.N. et al. Toxicological assessment of nanostructured silica. I. Integral indices, adducts of DNA, tissue thiols and apoptosis in liver. Voprosy pitaniya, 2014, vol. 83, no. 3, pp. 52-62 (in Russian).

5. Silicon dioxide, amorphous. Available at: http://www.fao.org/fileadmin/user_upload/jecfa_additives/docs/Monograph1/Additive-385.pdf (16.01.2017).

6. Van der Zande M., Vandebriel R.J., Groot M.J., Kramer E., Rivera Z.E.H., Rasmussen K. [et al.]. Subchronic toxicity study in rats orally exposed to nanostructured silica. Part. Fibre Toxicol, 2014, vol. 11, pp. 8.

7. Shumakova A.A., Efimochkina N.R., Minaeva L.P., Bykova I.B., Batishcheva S.Yu., Markova Yu.M. [et al.]. Toxicological assessment of nanostructured silica. III. Microecological, hematological indices, state of cellular immunity. Voprosy pitaniya, 2015, vol. 84, no. 4, pp. 55-65 (in Russian).

8. Zaitseva N.V., Zemlyanova M.A., Zvezdin V.N., Dovbysh A.A., Gmoshinskiy I.V., Khotimchenko S.A. Impact of silica dioxide nanoparticles on the morphology of internal organs in rats by oral supplementation. Health Risk Analysis, 2016, no. 4, pp. 80-94. DOI: 10.21668/health.risk/2016.4.10.eng

9. Titanium dioxide. World Health Organization. Available at: http://apps.who.int/food-additives-contaminants-jecfa-database/chemical.aspx?chemID=2723 (16.01.2017).

10. EFSA Panel on Food Additives and Nutrient Sources added to Food (ANS). EFSA Journal, 2016, vol. 14, no. 9 , pp. 4545.

11. Nohynek G.J., Lademann J., Ribaud C., Roberts M.S. Grey goo on the skin? Nanotechnology, cosmetic and sunscreen safety. Crit. Rev. Toxicol, 2007, vol. 37, no. 3, pp. 251-277. DOI: 10.1080/10408440601177780

12. Park E.J., Yoon J., Choi K., Yi J., Park K. Induction of chronic inflammation in mice treated with titanium dioxide nanoparticles by intratracheal instillation. Toxicology, 2009, vol. 260, no. 1-3, pp. 37-46. DOI: 10.1016/j.tox.2009.03.005

13. Bu Q., Yan G., Deng P., Peng F., Lin H., Xu Y. [et al.]. NMR-based metabonomic study of the sub-acute toxicity of titanium dioxide nanoparticles in rats after oral administration. Nanotechnology, 2010, vol. 21, no. 12, p. 125105. DOI: 10.1088/0957-4484/21/12/125105

14. Raspopov R.V., Vernikov V.M., Shumakova A.A., Sentsova T.B., Trushina E.N., Mustafina O.K. [et al.]. Toxicological sanitary characterization of titanium dioxide nanoparticles introduced in gastrointestinal tract of rats. Communication 1. Integral, biochemical and hematoliogic indices, intestinal absorption of macro-molecules DNA damage. Voprosy pitaniya, 2010, vol. 79, no. 4, pp. 21-30 (in Russian).

15. Arianova E.A., Shumakova A.A., Tananova O.N., Trushina E.N., Mustafina O.K., Sharanova N.E., Gmoshinsky I.V., Khotimchenko S.A. Influence of dioxide titanium nanoparticles on immune system indicators in rats. Voprosy pitaniya, 2012, vol. 84, no. 6, pp. 47-53 (in Russian).

16. Bettini S., Boutet-Robinet E., Cartier P., Coméra P., Gaultier E., Dupuy J. [et al.]. Foodgrade $\mathrm{TiO} 2$ impairs intestinal and systemic immune homeostasis, initiates preneoplastic lesions and promotes aberrant crypt development in the rat colon. Sci. Rep, 2017, vol. 7, pp. 40373. DOI: $10.1038 /$ srep40373

17. Tananova O.N., Arianova E.A., Gmoshinskiy I.V., Aksenov I.V., Zgoda V.G., Khotimchenko S.A. Influence of anatase titanium dioxide nanoparticles on protein expression profiles in rat liver microsomes]. Voprosy pitaniya, 2012, vol. 81, no. 2, pp. 18-22 (in Russian).

18. Koeneman B.A., Zhang Y., Westerhoff P., Chen Y., Crittenden J.p., Capco D.G. Toxicity and cellular responses of intestinal cells exposed to titanium dioxide. Cell. Biol. Toxicol, 2010, vol. 26, no. 3, pp. 225-238. DOI: 10.1007/s10565-009-9132-z

19. Onishchenko G.E., Erokhina M.V., Abramchuk S.S., Shaitan K.V., Raspopov R.V., Smirnova V.V., Vasilevskaya L.S., Gmoshinski I.V., Kirpichnikov M.P., Tutel'yan V.A. Vliyanie nanochastits dioksida titana na sostoyanie slizistoi obolochki tonkoi kishki krys [The influence of titanium dioxide nanoparticles on the state of the mucous membrane of the small intestine of rats.]. Byulleten' eksperimental'noi biologii i meditsiny, 2012, vol. 154, no. 8, pp. 231-237 (in Russian). 
20. AVIS de l'Agence nationale de sécurité sanitaire de l'alimentation, de l'environnement et du travail relatif à une demande d'avis relatif à l'exposition alimentaire aux nanoparticules de dioxyde de titane. ANSES, 2017. Available at: https://www.anses.fr/fr/system/files/ERCA2017SA0020.pdf (16.01.2017).

21. Demin V.A., Gmoshinsky I.V., Demin V.F., Anciferova A.A., Buzulukov Yu.P., Khotimchenko S.A., Tutelyan V.A. Modeling interorgan distribution and bioaccumulation of engineered nanoparticles (using the example of silver nanoparticles). Nanotechnologies in Russia, 2015, vol. 10, no. 3-4, pp. 288-296. DOI: 10.1134/S1995078015020081

22. Buzulukov Yu.P., Arianova E.A., Demin V.F., Safenkova I.V., Gmoshinski I.V., Tutelyan V.A. Bioaccumulation of silver and gold nanoparticles in organs and tissues of rats studied by neutron activation analysis. Biology Bulletin, 2014, vol. 41, no. 3, pp. 255-263. DOI: 10.1134/S1062359014030042

23. Van der Zande M., Vandebriel R.J., Doren E.V., Kramer E., Rivera Z.H., Serrano-Rojero P.S. [et al.]. Distribution, elimination, and toxicity of silver nanoparticles and silver ions in rats after 28-day oral exposure. ACS Nano, 2012, vol. 6, no. 8, pp. 7427-7442. DOI: 10.1021/nn302649p

24. Melnik E.A., Buzulukov Yu.P., Demin V.F., Demin V.A., Gmoshinski I.V., Tyshko N.V., Tutelyan V.A. Transfer of silver nanoparticles through the placenta and breast milk during in vivo experiments on rat. Acta Naturae, 2013, vol. 5, no. 3 (18), pp. 48-56.

25. Kim Y.S., Kim J.S., Cho H.S., Rha D.S., Kim J.M., Park J.D. [et al.]. Twenty-eight-day oral toxicity, genotoxicity, and gender-related tissue distribution of silver nanoparticles in SpragueDawley rats. Inhal. Toxicol, 2008, vol. 20, no. 6, pp. 575- 583. DOI: 10.1080/08958370701874663

26. Park E.J., Bae E., Yi J., Kim Y., Choi K., Lee S.H. [et al.]. Repeated-dose toxicity and inflammatory responses in mice by oral administration of silver nanoparticles. Environ. Toxicol. Pharmacol, 2010, vol. 30, no. 2, pp. 162-168. DOI: 10.1016/j.etap.2010.05.004

27. Shumakova A.A., Smirnova V.V., Tananova O.N., Trushina E.N., Kravchenko L.V., Aksenov I.V. [et al.]. Toxicological sanitary characterization of silver nanoparticles introduced in gastrointestinal tract of rats. Voprosy pitaniya, 2011, vol. 80, no. 6, pp. 9-18 (in Russian).

28. Khodykina N.V., Gorshenin A.V., Klauchek V.V., Pocheptsov A.Ya., Sroslov M.S., Tochilkina L.P. [et al.]. Eksperimental'noe izuchenie khronicheskoi peroral'noi toksichnosti sfericheskikh nefunktsionalizirovannykh nanochastits serebra [Experimental study of chronic oral toxicity of spherical nonfunctionalized silver nanoparticles]. Nanotoksikologiya: dostizheniya, problemy, perspektivy: materialy nauchnyi konferentsii. Volgograd, Stanitsa 2 Publ., 2014, pp. 65-66 (in Russian).

29. Zaitseva N.V., Zemlyanova M.A., Zvezdin V.N., Dovbysh A.A., Akafyeva T.I., Gmoshinski I.V., Khotimchenko S.A. Toxicological evaluation of nano-sized colloidal silver in experiments on mice. behavioral reactions, morphology of internals. Health Risk Analysis, 2015, no. 2, pp. 68-81. DOI: 10.21668/health.risk/2015.2.09.eng (in Russian).

30. Shumakova A.A., Shipelin V.A., Efimochkina N.R., Minaeva L.P., Bykova I.B., Markova Yu.M. [et al.]. Toxicological evaluation of colloidal nano-sized silver stabilized polyvinylpyrrolidone. IV. Influence on intestinal microbiota, immune indexes. Voprosy pitaniya, 2016, vol. 85, no. 3, pp. 27-35 (in Russian).

31. Shipelin V.A., Shumakova A.A., Masyutin A.G., Chernov A.I., Sidorova Yu.S., Gmoshinski I.V., Khotimchenko S.A. Influence of orally introduced silver nanoparticles on content of essential and toxic trace elements in organism. Nanotechnologies in Russia, 2016, vol. 11, no. 9-10, pp. 646-652. DOI: 10.1134/S199507801705010X (in Russian).

32. Zaytseva N.V., Zemlyanova M.A., Zvezdin V.N., Dovbysh A.A., Gmoshinskiy I.V., Khotimchenko S.A. [et al.]. Toxicological evaluation of nanosized colloidal silver, stabilized with polyvinylpyrrolidone, in 92-day experiment on rats. II. Internal organs morphology. Voprosy pitaniya, 2016, vol. 85, no. 1, pp. 47-55 (in Russian).

33. Smirnova E.A., Gusev A.A., Zaitseva O.N., Lazareva E.M., Onishchenko G.E., Kuznetsova E.V. [et al.]. Multi-walled carbon nanotubes penetrate into plant cells and affect the growth of onobrychis arenaria seedlings. Acta Naturae, 2011, vol. 3, no. 1, pp. 99-106 (in Russian). 
34. Mukherjee A., Majumdar S., Servin A.D., Pagano L., Dhankher O.P., White J.P. Carbon nanomaterials in agriculture: a critical review. Front.Plant Science, 2016, vol. 7, pp. 172. DOI: $10.3389 /$ fpls.2016.00172

35. Vasyukova I.A., Gribanovskii S.L., Gusev A.A., Ubogov A.Y., Khaliullin T.O., Fatkhutdinova L.M., Tkachev A.G. Assessment of reproductive toxicity of multiwalled carbon nanotubes and their putative effects on population ecology of mouselike rodents]. Nanotechnologies in Russia, 2015, vol. 10, no. 5-6, pp. 458-467 (in Russian).

36. Kavoosi G., Dadfar S.M., Dadfar S.M., Ahmadi F., Niakosari M. Investigation of gelatin/multi-walled carbon nanotube nanocomposite films as packaging materials. Food Sci. Nutr., 2014, vol. 2, no. 1, pp. 65-73. DOI: 10.1002/fsn3.81

37. Khripach L.V., Rakhmanin Iu.A., Mikhajlova R.I., Knyazeva T.D., Koganova Z.I., Zheleznyak E.V., Savostikova O.N., Alekseeva A.V., Ryzhova I.N., Kruglova E.V., Revazova T.L. Biochemical effects of chronic peroral administration of carbon nanotubes and activated charcoal in drinking water in rats. Gigiena i sanitariya, 2014, no. 5, pp. 36-42 (in Russian).

Gmoshinski I.V., Shipelin V.A., Khotimchenko S.A. Nanomaterials in food products and their package: comparative analysis of risks and advantages. Health Risk Analysis, 2018, no. 4, pp. 133-141. DOI: 10.21668/health.risk/2018.4.16.eng

Received: 18.10 .2018

Accepted: 15.11 .2018

Published: 30.12.2018 


\section{NEW LEGAL, REGULATORY AND METHODOLOGICAL DOCUMENTS ISSUED IN THE RF IN THE SPHERE OF HEALTH RISK ANALYSIS}

September 17, 2018-December 07, 2018

The Decision by The Board of the Eurasian Economic Commission No. 166 dated October 16, 2018 "On Approval of the list of products which, apart from a customs declaration, should be provided with a certificate of conformity with the requirements fixed in the Customs Union Technical Regulations "On safety of certain specific food products including dietetic clinical nutrition and dietetic preventive nutrition" (CU TR 027/2012) or confirmation that such a certificate has been issued.

The Decision specifies a list of products which, when being under customs procedures, should be provided with a certificate of their conformity with the requirements fixed in the Customs Union Technical Regulations "On safety of certain specific food products including dietetic clinical nutrition and dietetic preventive nutrition" (TP TC 027/2012). The above mentioned list includes specific food products for sportsmen' nutrition, specific food products for pregnant women and breast-feeding mothers, food products for dietetic clinic nutrition and dietetic preventive nutrition, including food products for children nutrition.

The Decision by The Board of the Eurasian Economic Commission No. 167 dated October 16, 2018 "On Approval of the list of products which, apart from a customs declaration, should be provided with a certificate of conformity with the requirements fixed in the EAEU Technical Regulations "On limiting application of hazardous substances in electrical and radio-electronic products" (EAEU TR 037/2016)»

The Decision specifies the list of products which, when being under customs procedures, should be provided with a certificate of their conformity with the requirements fixed in the EAEU Technical Regulations "On limiting ap- plication of hazardous substances in electrical and radio-electronic products" (EAEU TR 037/2016). The above mentioned list includes, among other things, electrical household appliances, computers and devices compatible with them, electronic communication means, copying machines and other electric office equipment, electrical instruments, light sources, and lighting equipment.

The Decision by The Board of the Eurasian Economic Commission No. 168 dated October 16, 2018 "On the list of international and regional (interstate) standards, and in case of their absence, national (state) standards that specify rules and techniques for examinations (tests) and measurements, including rules for sampling to be followed in order to provide conformity with the requirements fixed in the Customs Union Technical Regulations "On safety of certain specific food products including dietetic clinical nutrition and dietetic preventive nutrition" (CU TR 027/2012) and assessing conformity of products which are subject to technical regulation".

The decision updates the list of standards that specify rules and techniques for examinations (tests) and measurements, including rules for sampling to be followed in order to provide conformity with the requirements fixed in the Customs Union Technical Regulations "On safety of certain specific food products including dietetic clinical nutrition and dietetic preventive nutrition" (CU TR 027/2012).

The Decision by The Council of the Eurasian Economic Commission No. 75 dated September 14, 2018 "On making alterations into the Customs Union Technical Regulations "Food products and their marking" (CU TR 022/2011)" 
The Decision clarifies requirements to marking on food products. It fixes that an invented name of a food product (in case there is any) should be included into the denomination of this product and be placed next to it as close as it is only possible.

The decision also fixes the following criteria that make marking easy-to-interpret: they are clearness and readability of a font applied in marking, relevant size as well as contrast between a color of a background and a color of information printed on it, as they are to provide a possibility to read this information without any optical devices excluding those applied for visual deficiency correction (glasses, contact lenses, etc.). A comprehensibility criterion is unambiguity of a message that communicates information on a food product as a text or a text with a picture (pictures). A font size is regulated for certain data.

The Decision by The Council of the Eurasian Economic Commission No. 75 dated September 14, 2018 "On making alterations into certain Decisions by the EEC Council on issues related to marking of goods from the product group "Clothing, accessories, and other products made of natural furs"

The Decision clarifies certain decisions made by the EEC Council that regulate the procedure for marking of clothing and other products made of natural furs. It specifies that juridical persons and private entrepreneurs that operate in the EAEU member states and deal with retail trade in such products are to inform an authorized state body in a EAEU member state which they are registered in about identification marks made on a product. The information should be submitted electronically; the Decision also specifies minimum obligatory data about a marked product that are to be communicated.

The Decision by The Board of the Eurasian Economic Commission No. 171 dated October 30, 2018 "On classifying a biologically active additive in a form of chewing marmalade in accordance with the unified EAEU Commodity Nomenclature of Foreign Economic Activity"

The Decision specifies that a biologically active additive in a form of chewing marmalade that consists of sugar and(or) sugar syrups, jell- ing substances, vitamins, minerals, tasteadding, flavoring, and dying agents, applied as a balancing addition to children nutrition to serve as an additional source of vitamins and minerals should be classified within a commodity group No. 2106 of the EAEU CN FEA.

The Federal Law No. 407-FL issued on November 12, 2018 "On making alterations into the RF Code of Administrative Offences"

Liability for violation of sanitaryepidemiologic requirements in sanitary protection zones near water supply sources will be differentiated depending on a belt of such zones. The law fixes that violation of sanitaryepidemiologic requirements on a territory of a zone belonging to the third belt of a sanitary protection zone around a water source for drinking and communal water supply will entail an administrative penalty; citizens will be charged a penalty from 3,000 to 5,000 rubles; public officials, from 10,000 to 15,000 rubles; juridical persons, from 300,000 to $500,000 \mathrm{ru}$ bles. The same violation committed on a territory of the second belt zone will entail an administrative penalty from 5,000 to $10,000 \mathrm{ru}-$ bles for citizens; for public officials, from 20,000 to 40,000 rubles; for private entrepreneurs, from 20,000 to 40,000 rubles or administrative suspension on activities for a period up to 90 days; for juridical persons, from 500,000 to 600,000 rubles, or administrative suspension on activities for a period up to 90 days.

In case sanitary-epidemiologic requirements are violated on the first belt territory, it will entail an administrative penalty from 10,000 to 20,000 rubles for citizens; for public officials, from 50,000 to 80,000 rubles or administrative suspension on activities for a period up to 90 days; for private entrepreneurs, from 50,000 to $80,000 \mathrm{ru}$ bles or administrative suspension on activities for a period up to 90 days; for juridical persons, from 600,000 to 1 million rubles or administrative suspension on activities for a period up to 90 days.

The RF President Decree No. 585 dated October 13, 2018 "On Approval of the Fundamentals of the state policy in the sphere of providing nuclear and radiation safety in the Russian Federation for a period up to 2025 and subsequent years" 
The document specifies fundamentals of implementing the state policy in the sphere of providing nuclear and radiation safety; among other things, they include:

- providing protection from exposure to radiation for workers (personnel) employed at nuclear power stations and nuclear objects where materials with elevated contents of natural radionuclides are applied; the same protection should be provided for population and the environment;

- maintaining the lowest possible irradiation doses for population on radiation-contaminated territories in the RF and for population exposed to radiation factors due to natural irradiation sources;

- updating regulatory and legal base for nuclear and radiation safety;

- updating state regulation over safety of nuclear energy; stricter control at the RF state borders and territorial waters, prevention of illegal imports and exports of radioactive substances, products made of them, radioactive materials and wastes;

- adhering to a principle of imports substitution in nuclear energy sphere;

- better anti-terrorist protection of nuclear power stations, nuclear objects, and devices that produce ionizing irradiation;

- ensuring availability and transparency of information on radiation state, environmental safety and products safety, provided that state secrets as well as other ones are strictly guarded.

The RF President Decree No. 680 dated November 28, 2018 "On development of genetic technologies in the Russian Federation"

The RF President gave an order to work out the Federal scientific and technical program for the development of genetic technologies for 2019-2027. The Program should be aimed at streamlining development of genetic technologies, including those for genetic editing; providing creation of biological preparations, diagnostic systems, and immune-biologic drugs for public healthcare, biotechnologies for agriculture and industry; as well as updating measures for preventing emergencies related to biologic hazards and for control in the sphere.

The document fixes that it is necessary to create and keep an information and analytical system for operative monitoring and assessment of scientific and technical support for research in the sphere of genetic technologies, risks of uncontrolled spread and application of such technologies; it is also necessary to create and develop laboratories and centers that accomplish research in genetic technologies sphere, including technologies for genetic editing, and to provide technical support for them as well as to train experts in the field.

The RF Government Program "Key lines of activity by the RF Government for the period up to 2024" (approved by the RF Government on September 29, 2018)

The Program fixes that The RF Government will first of all concentrate on achieving the RF national development goals stated in the RF President Decree No. 204 signed on May 7, 2018 , including a set of activities aimed at increasing birthrate, decreasing population mortality, and longer period of healthy life.

Real incomes of population will grow due to stable and dynamic economic development of the country, increased salaries and wages paid to workable population, social payments indexation, and development of targeted aid programs for citizens in need.

As far as the development of the pension system is concerned, the Program envisages a step-by-step increase in the overall retirement age as it will allow to provide higher pension payments and annual pensions indexation; accumulation of additional pension resources of citizens within private pension systems; development of early retirement system; it will also stimulate creation and development of corporate pension systems.

Annually not less than 5 million families will be provided with better housing; it will be achieved due to creation of conditions for buying (building) housing with mortgage loans granted at interests rates lower than $8 \%$ and an increase in housing construction up to not less than 120 million square meters per year.

The RF technological development will be streamlined due to elimination of regulatory barriers for innovative products and new technological solutions; promoting easier access to high-technology equipment; development of digital services to support innovations. 
The Program also states that it is necessary to create a unified network of scientific and educational centers, competence centers for the national technological initiative, agricultural biotechnoparks, and other research centers that will participate in development of technologies, products, and services and their introduction to the market together with economic entities operating in the real sector of the economy.

Streamlined implementation of digital technologies will be provided due to creation of legal regulation system for the digital economy, creation of global competitive infrastructure for data transferring, processing, and storage predominantly on the basis of domestic developments; implementation of digital technologies and platform solutions in public administrations and provision of public services, creation of a unified platform based on a "onewindow" principle for providing citizens with a single access point to interact with the state.

The strategic goals of the country development are as follows: the RF economy should be among the top five economies in the world; economic growth in the country should be faster than the average world one; macroeconomic stability should be preserved, and inflation rate should not exceed $4 \%$. These goals will be achieved due to capital investments growth, private investments growth, creation of stable and easy conditions to do business (stable taxation; predictable tariff regulations; transparent and predictable regulation over tax payments made by entrepreneurs; lower risks related to criminal procedures imposed on entrepreneur activities; more efficient control and surveillance activities; better access to long-term financing for investment projects, etc.).

The RF Governmental Regulation No. 2413-r dated November 08, 2018 "On Approval of the list of activities aimed at development of legal regulation over land relations"

The RF Government fixed the activity plan for developing legal regulation over land relations. The list of activities includes, among other things, making alterations into the RF Land Code and specific subordinate legal acts; the alterations will envisage the following:

- protection from voluntary and (or) unjustified changes in a list of allowed utilization of land lots;
- transfer from distributing lands into categories to territorial zoning;

- clarification of procedures for application of limitation period for bargains related to acquisition of land;

- development of a procedure for compensating for damage caused by changes made in a list of allowed utilization or by limiting rights for a land lot without consent of a person whom this land lot belongs to;

- fixation of signs proving that land lots aimed for agricultural purposes have not been utilized;

- prevention of situations in which objects that are not aimed for agricultural production are located on agricultural lands;

- development of a system for giving mortgages on the security of agricultural lands.

The RF Governmental Regulation No. 1314 dated November 03, 2018 "On making alterations into some RF Government Regulations related to exercise of powers by specific federal executive authorities in the sphere of solid communal wastes treatment"

The Ministry of Natural Resources and the Environment of the Russian Federation is granted authority to develop a state policy in the sphere of communal and industrial wastes treatment and solid communal wastes treatment.

The RF Governmental Regulation No. 1398 dated November 21, 2018 "On Approval of rules for organizing and accomplishing a test purchase when specific state control (surveillance) is being performed"

The document fixes the procedure for test purchasing. It is stated that a test purchase should be accomplished in situations fixed in federal laws and be substantiated by reasons for unscheduled field inspections fixed in the Federal Law "On protection of rights of juridical persons and private entrepreneurs in situations when state control (surveillance) and municipal control is being accomplished". A test purchase is to be accomplished in situations when it is the only way to assess whether requirements fixed in the legislation are met when goods are sold, works are accomplished, and services are rendered to a consumer. In other situations a field inspection is to be accomplished. 
Provisions on types of federal state control (surveillance) that incorporate the riskoriented approach can envisage that state control (surveillance) authorities can apply certain risk indicators implying that obligatory requirements can be violated to determine a necessity to accomplish a test purchase.

In particular, the document fixes the following:

- the procedure for making a decision on test purchase accomplishment;

- requirements to a text of an order to accomplish a test purchase;

- peculiarities of accomplishing a test purchase with cash or non-cash payments;

- the procedure for test purchase accomplishment;

- the terms within which a report on test purchase results is to be issued and measures are to be taken as per these results (in case of necessity);

- requirements to the contents of a report on test purchase results.

The RF Governmental Regulation No. 1399 dated November 21, 2018 "On making alterations into the Rules for creation and keeping the Unified Inspections Register"

The Unified Inspections Register is to contain information on new types of inspections, their results and taken measures, including those concerning:

- activities performed by local bodies and local officials;

- federal executive bodies, other bodies that perform federal executive functions, regional authorities, local bodies as well as state offbudget funds, and people without a legal state of a private entrepreneur.

The Register is also to contain information on a test purchase accomplished when state control (surveillance) and municipal control is performed.

The document fixes that an overall scope of information included into the Unified Inspection Register is to be considered an electronic certificate of an inspection or a test purchase. The document also clarifies contents of such certificates as well as terms of their submission to the Unified Inspection Register as well as rules for granting access to the data kept in the Register for citizens and organizations.
The RF Governmental Regulation No. 1952-r dated September 17, 2018 "On Approval of the activity plan for implementing The Fundamentals of the RF State Policy in the sphere of industrial safety for the period up to 2025 and subsequent years"

The document fixes the plan of activities that will allow to implement the Fundamentals of the state policy in the sphere of industrial safety for the period up to 2025 and subsequent years. These activities will help to gradually reduce risks of emergencies at industrial objects, to update approaches and techniques of the state regulation in the sphere taking into account the latest requirements and conditions; in particular, they include the following:

- approval on federal standards and rules in the industrial safety sphere;

- making alterations into the Federal Law "On industrial safety at hazardous industrial objects" as regards implementation of remote control and state monitoring over industrial safety; development of legal procedures related to liability for violation of safety requirements; fixing a legal status of organizations that provide scientific and technical support;

- working out and approval on standard programs for skills development or staff retraining in the industrial safety sphere;

- development and implementation of information resources in order to provide industrial objects safety;

- preparation of documents that envisage greater role played by obligatory insurance of civil liability for damages caused by an emergency at a hazardous object.

The RF Governmental Regulation No. 2322-r dated October 27, 2018 "On Approval of lists including perfume and cosmetic products, household chemicals, and products for personal hygiene distribution of which is not subject to regulation by the Federal Law "On state regulation over manufacturing and distribution of ethanol, alcohol and alcohol-containing products and on limiting alcohol consumption (drinking)"

The document updates lists of perfumes, cosmetics, household chemicals, and products for personal hygiene distribution of which is not subject to regulation by the Federal Law 
on state regulation over manufacturing and distribution of alcohol products.

In order to achieve conformity of these lists with the existing legislation and to take into account implementation of the latest all-Russian products classifier as per types of economic activity, the document fixes two lists of products and goods, according to the all-Russian products classifier, and according to the EAEU CN FEA.

The RF Governmental Regulation No. 2555-r dated November 22, 2018 "On fixing quantities of specific ozonedepleting substances in permissible volumes of consumption for ozone-depleting substances in the Russian Federation and permissible production volumes for ozonedepleting substances in the Russian Federation for 2019"

The document fixes permissible volumes of production and consumption for ozonedepleting substances in 2019 in the RF. The Montreal Protocol on substances that deplete the ozone layer envisages step-by-step reduction of their production and consumption up to complete ban on them in 2030 .

The RF Governmental Regulation No. 1452 dated November 30, 2018 "On making alterations into the Provisions on the state ecological monitoring (the state environmental monitoring) and the state database of the state ecological monitoring (the state environmental monitoring)"

The document clarifies what data are to be submitted by the Federal Service for Surveillance over Use of Natural Resources (Rosprirodnadzor) and regional authorities into the state database of the state ecological monitoring. It states that Rosprirodnadzor and the above-mentioned authorities are to submit information about the results of the state accounting of objects that exert negative impacts on the environment and the data on which are included into relevant federal and regional state registers.

The RF Governmental Regulation No. 1452 dated November 30, 2018: On making alterations into the Provisions on the state control over quality and safety of medical activities"
The RF Ministry of Labor will not perform any inspections to check whether organizations or private entrepreneurs that deal with public healthcare provide safe working conditions. The document clarifies that the state control in the sphere is to be accomplished by the Federal Service on Surveillance in Healthcare via inspecting whether activities performed by organizations and private entrepreneurs that deal with healthcare meet all the requirements to safe application and operation of medical appliances and their utilization (elimination).

The Order by the Federal Agency on Technical Regulating and Metrology No. 1859 dated September 06, 2018 "On making alterations into the Order by the Federal Agency on Technical Regulating and Metrology No. 647 dated March 29, 2017 and the Methodical recommendations on development and implementation of a program for preventing damages caused by products not conforming to requirements fixed by technical regulations approved by the above-mentioned order

The Order clarifies spheres for applying the Methodical recommendations on development and implementation of a program for preventing damages caused by products not conforming to requirements fixed by technical regulations.

It is envisaged that the above-mentioned Methodical recommendations approved by the Order by the Federal Agency on Technical Regulating and Metrology No. 647 dated March 29, 2017, are not to be applied concerning requirements fixed in the Customs Union Technical Regulations "On safety of wheeled vehicles" and "On requirements to motor petrol, aviation petrol, diesel fuel, vessel fuel, jet engine fuel, and fuel oil".

The Order by the RF Ministry of Labor No. 564n dated August 30, 2018 "On Approval of the occupational standard "Expert in risk management". Registered in the RF Ministry of Justice, registration entry No. 52177 dated September 17, 2018.

The Order updates the occupational standard for experts in risk management that is to 
replace the standard approved by the Order by the RF Ministry of Labor No. 591n dated September 07, 2015.

According to the Standard, key targets of activities performed by such experts are to create a strategic integrated risk management system, to maintain risks level that provides uninterrupted economically safe activities and stable development of an organization, social and economic systems and processes at various management levels. Functions performed by such experts include risk analysis and assessment; development of specific functional activities in risk management; creation of an integrated risk management system; methodical support and coordination for risk management; strategic regulation, control, and audit of risk management; strategic risk management in an organization. The standard fixes the requirements to education and work experience that an expert should have to efficiently perform the above-mentioned functions.

The Order by the RF Ministry of Labor No. 600n dated September 27, 2018 "On Approval of the occupational standard "Expert in safety of goods and services for children". Registered in the RF Ministry of Justice, registration entry No. 52422 dated October 12, 2018.

The Order approves the occupational standard for experts in safety of goods and services for children. According to the standard, the key target of activities performed by such experts is to provide safety of goods for children distributed on the market and safety of services rendered to children. Such experts are to perform the following functions: to provide laboratory and technical support for assessing and providing safety of goods and services for children; to accomplish primary and routine control over safety of manufactured goods and rendered services; to perform technical control and assess safety of goods and services for children when they are designed, manufactured, transported, stored, and sold; to accomplish inspections to check safety of goods and services for children. The standard fixes the requirements to education and work experience that an expert should have to efficiently perform the above-mentioned functions.
The Order by the Rospotrebnadzor No. 696 dated August 21, 2018 "On Approval on the list of tonics (tonic components) that cannot be contained in alcohol products with ethanol contents being less than $15 \%$ of the total volume of a finished product when such products are manufactured (excluding products manufactured for exports from the Russian Federation) and (or) distributed (excluding purchase, deliveries, storage and (or) transportation for exports from the Russian Federation)". Registered in the RF Ministry of Justice, registration entry No.52356 dated October $08,2018$.

The Order fixes the list of prohibited tonics that should not be contained in alcohol products with overall ethanol contents being less than $15 \%$. The list includes caffeine; caffeine-containing plants and extracts (tea, coffee, guarana, mate) excluding decaffeinated ones; puntu of marals and deer as well as their extracts; plants and products obtained via their processing (14 plants overall, including ginseng, Chinese magnolia-vine, bottle tree).

\section{The Letter by Rospotrebnadzor} No. 01/12718-2018-29 dated October 01, 2018 "On LED lamps used for lighting"

Rospotrebnadzor allows to use LED lamps for lighting in medical-preventive organizations. It is stated that lighting appliances, regardless of applied lighting sources and lighting devices are to meet standard requirements to overall artificial lighting fixed by the SER 2.2.1/2.1.1.1278-03 "Hygienic requirements to natural, artificial, and combined lighting of houses and public buildings" and contained in Tables 1 and 2 in the above-mentioned SER 2.2.1/2.1.1.1278-03.

\section{The Letter by Rospotrebnadzor} No. 01/11156-2018-32 dated August 27, 2018 "On application of sanitary rules"

Sanitary measures are to be applied to products (goods) that are subject to sanitaryepidemiologic surveillance (control) and that are included, according to the Eurasian Economic Commission documents, into the unified list of products (goods) that are subject to sanitary-epidemiologic surveillance (control), and that are to conform to the unified sanitary- 
epidemiologic and hygienic requirements and procedures. The unified sanitary-epidemiologic and hygienic requirements to products (goods) for which the Customs Union Technical Regulations are developed are to be included into such regulations in accordance with the Eurasian Economic Commission documents. Conventional principles and rules of the international law and international treaties signed by the RF are an integral part of the RF legal system. If an international treaty signed by the RF fixes rules that are not similar to those fixed in the RF law, than rules from this international treaty are to be applied. Therefore, sanitaryepidemiologic rules and hygienic standards concerning requirements to products and related processes for which there are existing relevant Customs Union Technical Regulations are considered valid as regards their provisions that do not contradict the RF legislation, including the Federal Law on technical regulations and subordinate acts, and, accordingly, the above-mentioned provisions of the Customs Union treaty and requirements fixed by the Customs Union Technical Regulations.

The Letter by the Ministry of Construction Industry, Housing and Utilities Sector of the Russian Federation No. 39818-CM/09 dated September 26, 2018 "On examination of an application"

The letter clarifies the order for imposing limitations in zones with specific conditions for utilization of territories (ZSCUT). If a ZSCUT regime does not impose any limitation on placing a capital construction object within ZSCUT boundaries, and such an object will be located on several land lots in this ZSCUT, a developer or a technical buyer, at his own option, submits construction documentation and results of engineering survey to be examined either by state authorities or a non-governmental organization. The Provisions fixed by items 3 and 4, Clause 49 of the RF Civil Code are to be applied regardless of whether data on a ZSCUT are contained in urban development plans for this particular land lot. Owners of land lots and real estate objects located on them that are within ZSXUT boundaries are to be notified by a register body that data on ZSCUT have been included into the Unified State Register for Real
Estate or about alterations of such data according to the procedure fixed by the federal legislation.

The Letter by the RF Ministry of Natural Resources and the Environment No. 341 dated July 31, 2018 "On fixing the procedure for creating and keeping the list of techniques for calculating emissions of hazardous (contaminating) substances into the atmosphere by stationary sources" Registered in the RF Ministry of Justice, registration entry No.52502 dated October 23, 2018.

The Letter fixes the procedure for creating and keeping the list of techniques for calculating emissions of hazardous (contaminating) substances into the atmosphere. It regulates the following: a volume of data included into the list; a procedure for entering data on a specific technique into the list; terms within which materials submitted to enter data into the list of techniques are to be registered, and terms within which applications on including a technique into the list are to be examined; reasons for return of the submitted materials to an applicant; procedures and terms for informing applicants on decisions made as per results of examinations of applications.

The Letter by the RF Ministry of Natural Resources and the Environment No. 352 dated August 07, 2018 "On Approval on the procedure for inventories of stationary sources and emissions of hazardous (contaminating) substances into the atmosphere, adjustment, documenting and storage of data obtained during such inventories" Registered in the RF Ministry of Justice, registration entry No.52522 dated October 24, 2018.

The Letter fixes the procedure for performing an inventory of stationary sources and emissions of hazardous (contaminating) substances into the atmosphere, as well as adjustment, documenting, and storage of data obtained during such inventories. In particular, the document fixes the following: tasks to be accomplished during an emission inventory; rules for systematizing data on emission sources during an inventory; the procedure for determining emission parameters during an inventory; rules for documenting and storage of data obtained during an inventory. 